
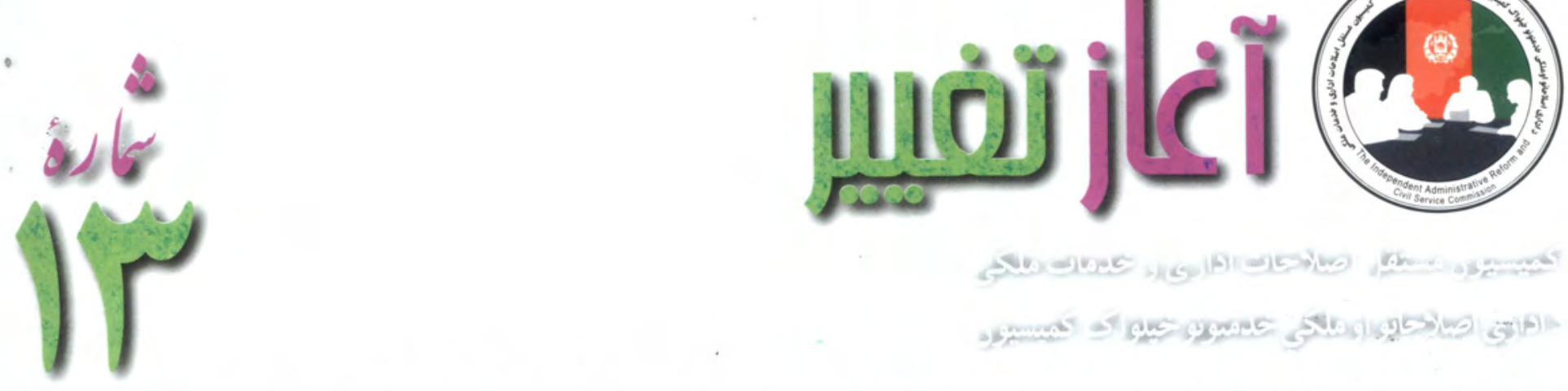

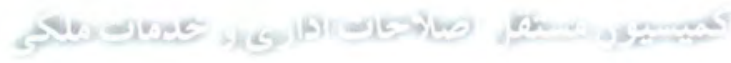

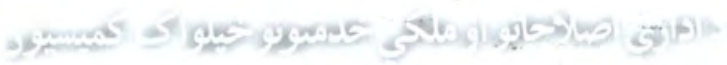

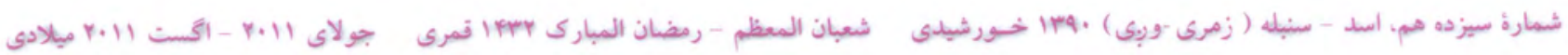

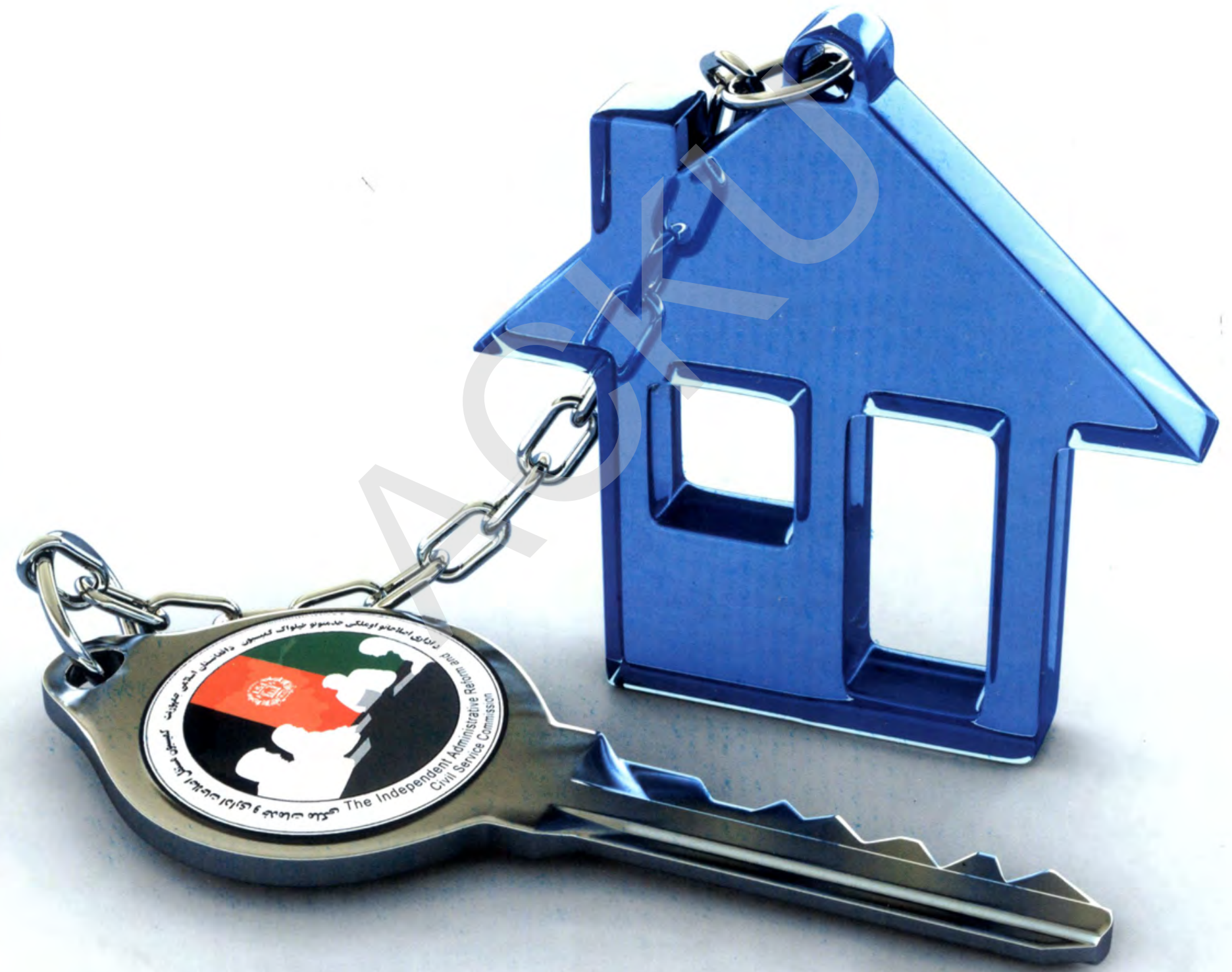


th

$y=$

• پاذاش هميشه و همه جا اتفاق مى افتل، هر خه زودتر بآن هماهنك شويد به . تفعتان است.

قبرنده ها كار هائى را انجام مى دهند كه بازنفه ها اصلاً دوســت ندارنف انجام 4 .

كهند.

• مؤفقيت از روز تولد به شـما تعلق كر فته، فرق در نتيجة انحراف از مسير زنفه كى متعادل شماست.

• آنجا و آنحه راكه هسـلِى، افكار و باور هايت رقم زه اند. افكار و باورهايت را تغييز بده، تا آنجا و آنجه را كه هستى تغييز كهى.

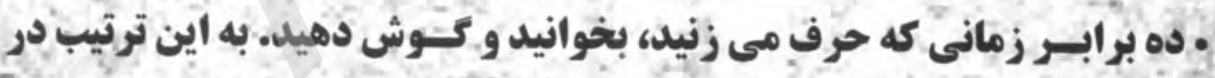

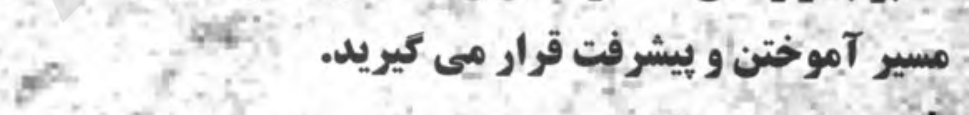

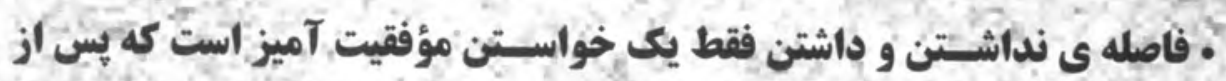
p(n) آنكه ديكران وا دادنف، تو تسـليم نشــوى.

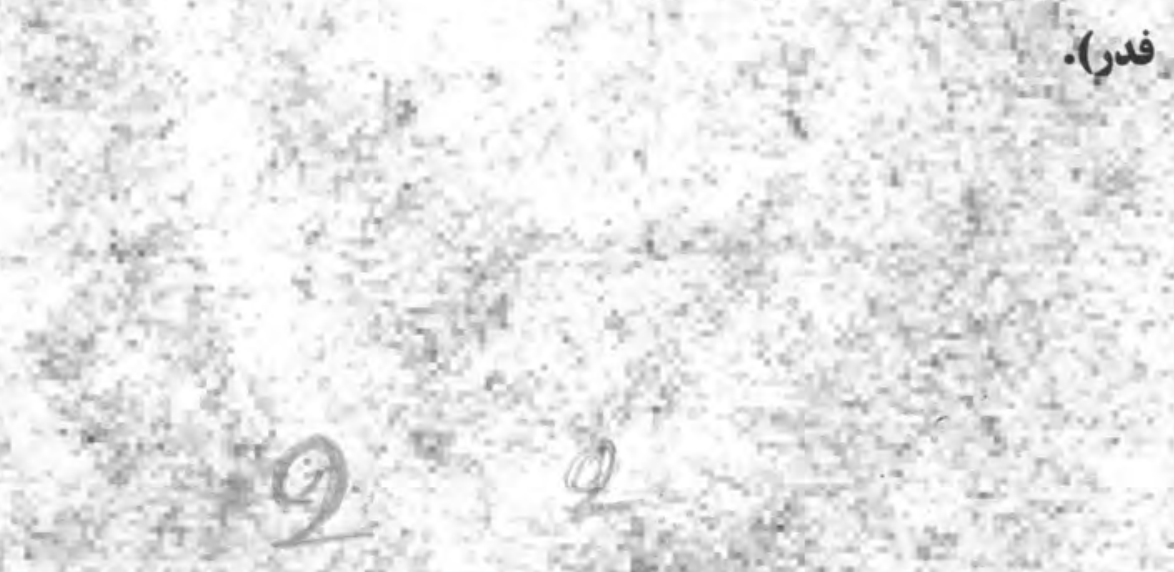


Y ـ فرار كادرها، جالش بزرى در اداره هاى دولتى است / كزارش .

$$
9
$$$$
\text { ـ د بشـــري منابعو رياســنونه بايد بو نويو معيارونو سمبال شي }
$$
هـ اصلاح اداره هاى خدمات ملكى افغانستان اصلى براى ايجاد حكومت مؤثر است ... ir لـ توسعه منابع انسانى؛ اولويت اصلى افغانستان / الملاحات و توسع ...

$$
\text { iv }
$$
ـ بانك معلوماتى ، اساس تعقل كرايى در تعيين باليسى هاى اصلاحات و حكو متدارى خوب ...

19 ـ اصلاحات ادارى عمومى در ماليزيا) مطلب

Y1 لـ زنان و مديريت/ زن و اداره .

YF. كم كميسون به تساوى جنسيت در اداره هـا بيشتر توجه كند / مساحب ....

YY لـ د افغانستان به اساسي قانون كي د بنخو حقوق / علب .

rq لـ نقش بانوان در انستجام جامعه و خانواده / عطلب .

FI لـ شيوة مديويت هُشام مسلكى است / جهرهما

rF لـ افغاني اداره د تاريخ به بانو كي / بيش الصلاحان در انفانستان . S1486

re له نكاهى به روند ارزيابى از اجرالات كاركنان/ دستاور دها و جالش ها. .

rA هـ كزارشى از روند اصلاحات ادارى در وزارت صحت عـامـه .

P. لـ مؤلفه هاى مهمر مديريت در خدمات ملكى / آموزث مديريت .

Pr ه ويؤم كى هاى رسانش بيام در خبر / رسانه ها وارتباطات ...

PF لـ منابع بشرى جيست و جه نقشى در توسعه مديريت دارد ؟ / منابع بشىى

Fq لـ نيازمندى هاى مبرم جامعه افغانى و دلايل احياى مجدد كويراتيف هاى زراعتى در افغانستان. FA. لـ به بكتيكا كي د كومارني بهير به ويوه شفافه توكه برمخخ روان دى/ رويداد، كزارش و كثنكو. . $\Delta \cdot$ لـ ارتقاى ظرفيت، بهترين كزينه براى ايجاد توانمندى كاركنان است .

$\Delta 1$ 4 ارزيابى بيش از جهار هزار مامور خدمات ملكى در حسـوزه شمال .

Ar. ك عدم همكارى شركاى كميسيون در شمال از مشكلات جدى است ...

$\Delta F$ لـ اريكب، به يوه تولنه كي د برمختك إين توك تشكيلوي .

$\Delta \Delta$ 4 اصـلاحات از ديدكاه ديكران / صنغه شما . .

\section{نشانى مجله}

رياست اطلاعات و ارتباط عامه

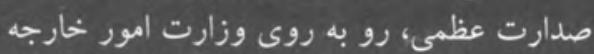

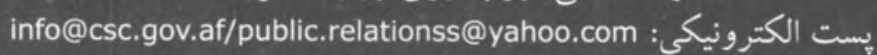
صفحه الكترونيكى: www.iarcsc.gov.af

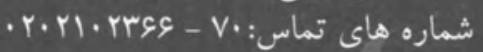

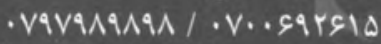
يست بكس هIFI كابل، ه افغانستان
كميسيون مستقل اصلاحات ادارى و خدمات ملكى اركى رياست عمومى دار الانشاء، ادارة اطالاعات و ارتباط عامه فئه

عزيزاله آريافر زير نظر تروه نويسنده كان

سردبير و ويراستار: جاويد فرهاد

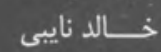
فيض الله صافى نمانى محمد فاروق بيويل سيد فقير اكبرى، محمد هادى رويش

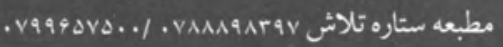

صاحب امتياز:

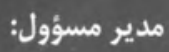

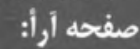
ويراستار يشتو: عكاس - خبرنكار: تززارشكران: 


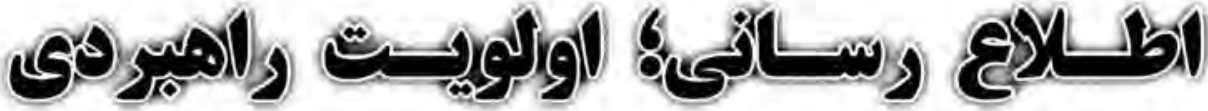

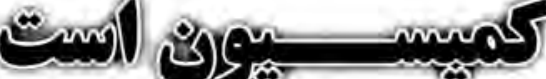

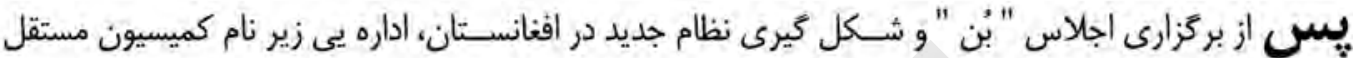
اصلاحات ادارى و خدمات ملكى در كشور ايجاد شد.

عمده ترين هدف راهبردى از ايجاد اين كميسيون، اصلاح ساختار اداره هاى خدمات ملكى در افغانستان بود (و آندان

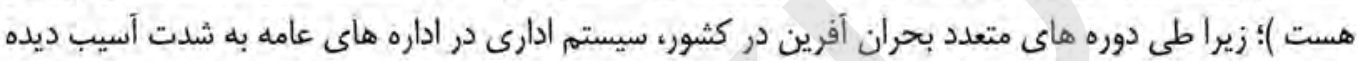

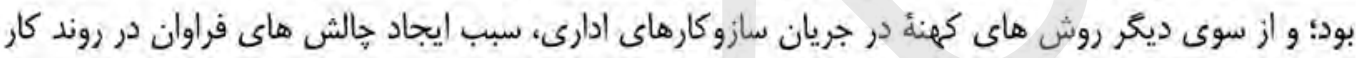

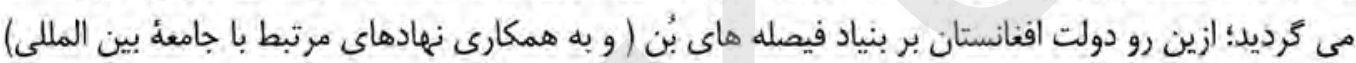

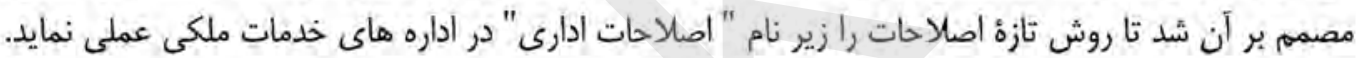

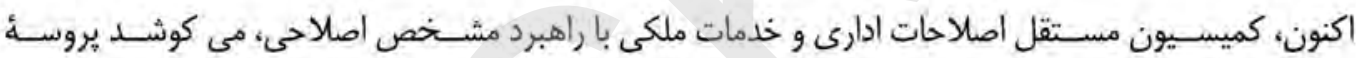

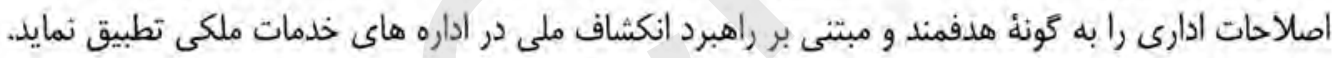

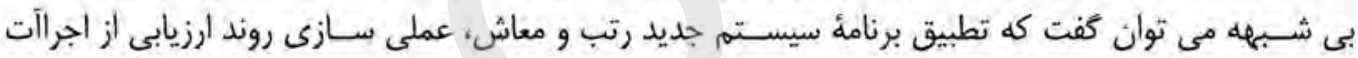

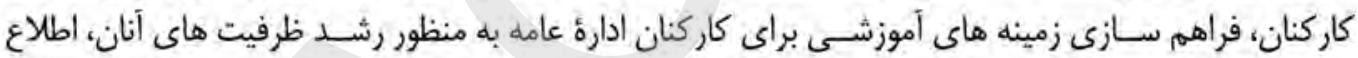

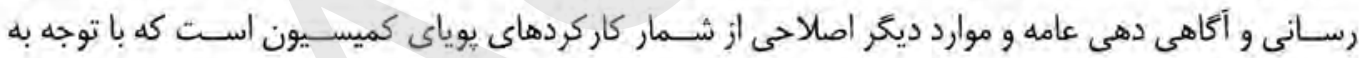

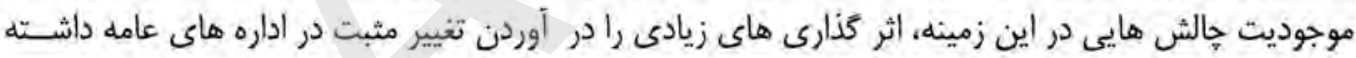
است.

همان كونه كه در جنب سـاير فعاليت هاى كميسـيون كفته شد، اطلالع رسـانى به منظور يخش أكاهى عامه، از اولويت هاى مهمر راهبردى اين نهاد است كه كميسيون در راستاى تطبيق آن همواره سعى نمون نموده است.

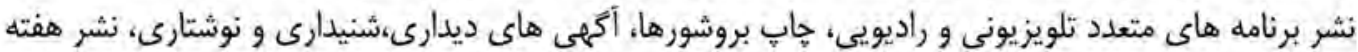

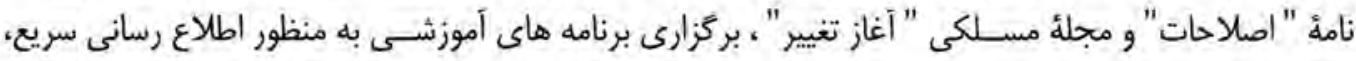

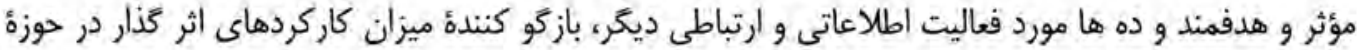
اطلاع رسانى و آكاهى عامه در كميسيون است وهن.

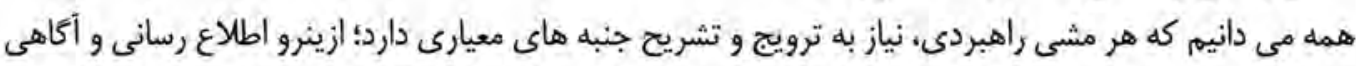

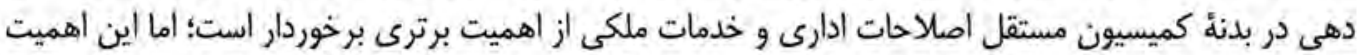

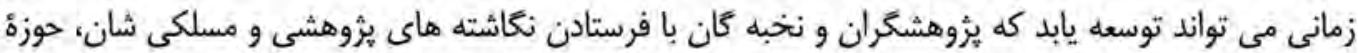

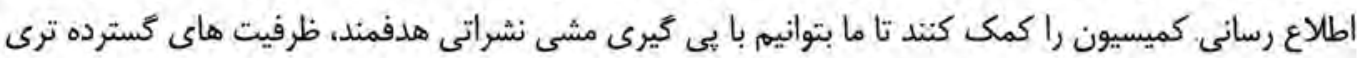

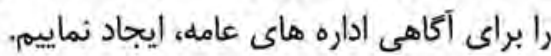



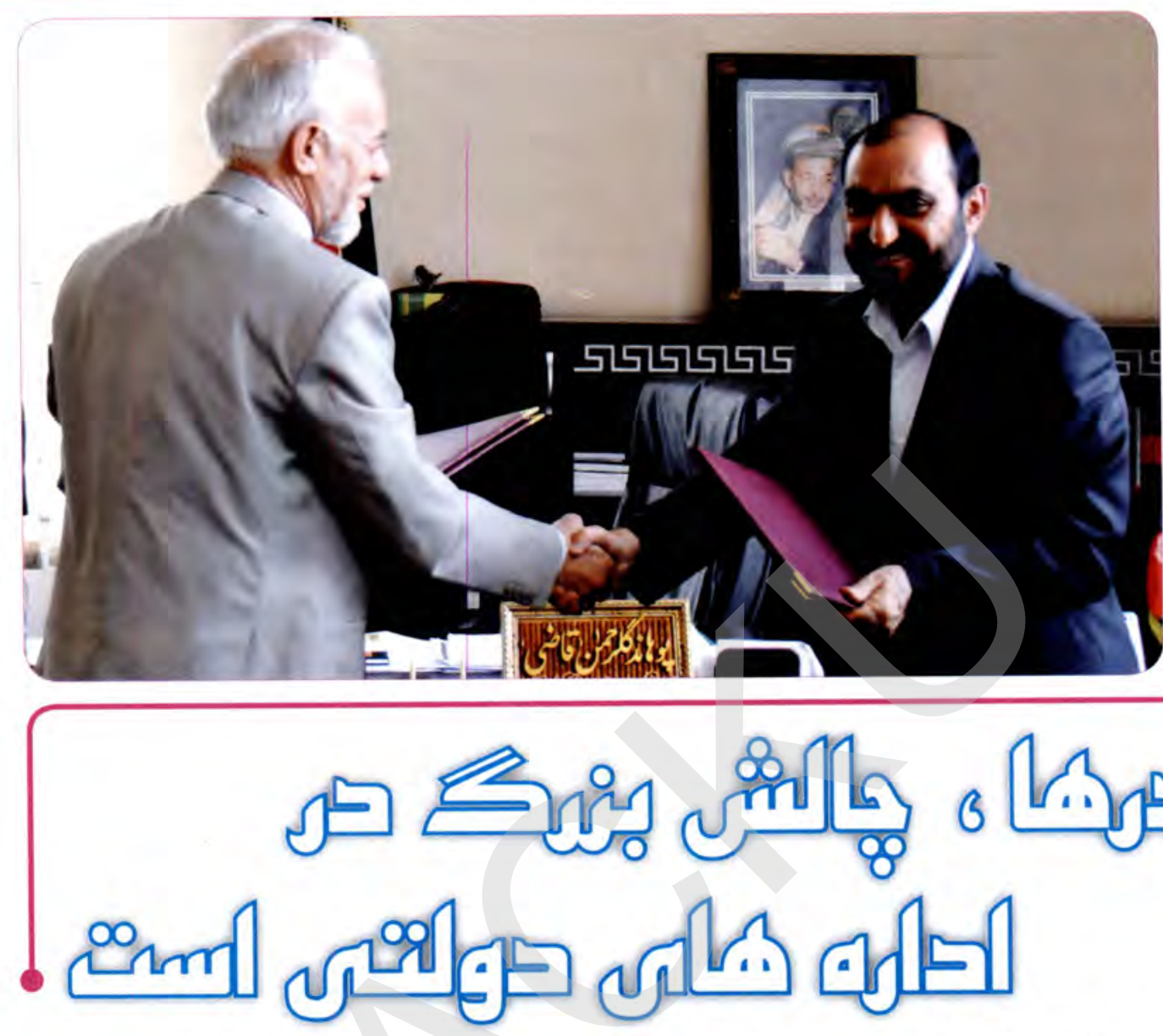

يوهاند 》 كل رحمان قاضى " رييس كميسـيون نظارت بر تطبيق قانون اساسـى ،بــا اظهار قدر

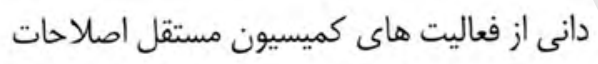
ادارى و خدمــات ملكـى كفت: » كميسـيون نظارت بر تطبيق قانون اساسـى ، آماده اسـت در تمام يروســه ها با كميسيون مستقل اصلاحات ادارى و خدمات ملكى همكارى نمايد. ما اميدواريم با همكارى كميسيون مستقل اصلاحات ادارى، افراد

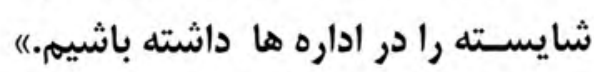

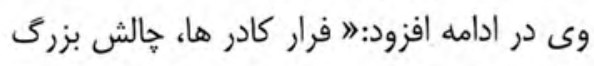

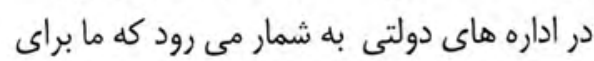

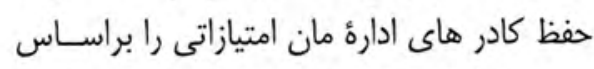
قانون خواهانيم تا از يك طرف توانســـه باشيم
كميسيون مسـتقل اصلاحات ادارى نيز اشترى داشـتند. در اين نشسـت بحث و مو تبادل نظر در مــورد قانون كاركنان خدمات ملكى نيز صورت كَرفت. - اكت داكتر ا(احمد مشـاهد رييس كميسيون مستقل

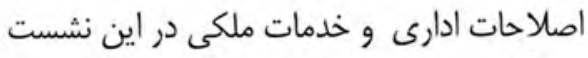
كفت:" مشـكلات در عرصه هاى مختلف و بــه خصوص در اداره هاى افغانسـتان وجود دارد. ما براى تطبيق بهتر قانون و در مجموع مديريت و تغيير مديريت در اداره هاى ملكى كشور و همينطور براى مدي لدئ ايجاد اداره هاى سـالم و غير سياسـى ملى مارى دولتى، تلاش بيشترى خواهيم كرد..؛
توافق نامهٔ دوجانبه ر رتب و معاش ميان كميسـيون مسـتقل نظــارت بــر قانون اساسى و كميسـيون مستقل اصلاحات ادارى و خدمـات ملكى اخيـرأ به امضاء رسيد. در نشســى كه به ايــن منظــور دردر دفتر كار رييس كميسيون نظارت بر قانون اساسى برگز ار شده بود، "داكتر احمد مشاهد " رييس كميسيون نطات برن مستقل اصلاحات ادارى و خدمات مكلى ،يوهاند إدماند "كل رحمان قاضى" رييس كميسـيون نظارت

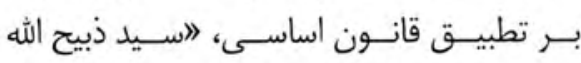

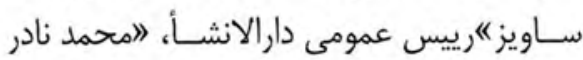
هوتك" رييس بوردتعيينات و سـاير مسؤولان 
تعيينات كميسـيون مسـتقل اصلاحات كرد. يكسى از راه هايى كه مى تواند ما را در بهتر ساختن اين قانون كمك رساند،

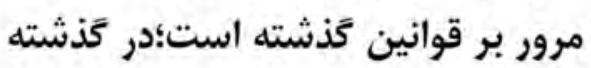
نيـز قوانينى براى خدمـات ملكى وجود

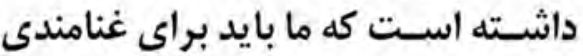

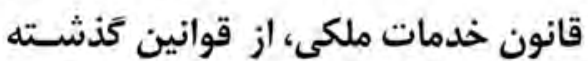

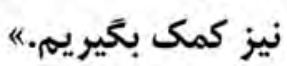

كميسـيون مسـتقل نظــارت بر تطبيـق قانون اساسـى به تاريخ 19 جوزاى

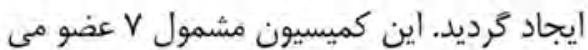

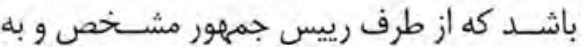
تأييد مجلس نماينده كان تعيين مى كردند.

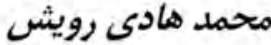

ادارى نيز اسـتخدام ها براساس رقابت

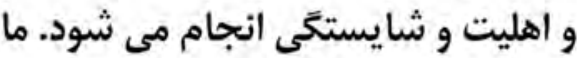
تلاش مى نماييم استخدام ها بدون هر

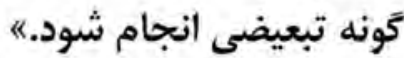

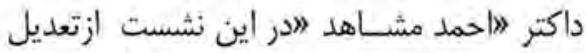
قانسون خدمات ملكسى خبرداد و از كميسـيـيون

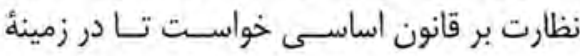

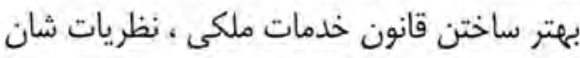

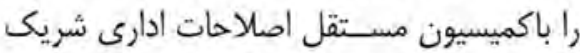

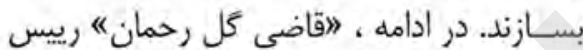
كميسيون نظارت بر قانون اساسى درمورد تعديل

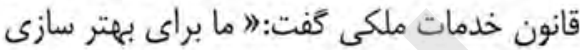
و غنامنــى قانون خدمات ملكى تلاش خواهيه
كادر هـاى مان را حفظ كنيم و از سـوى ديخر افراد شايسته را در اداره ها نيز حفظ نماييم." بر اساس مادة هِنجاهم قانون اساسى ، دولت مكلف است به منظور ايجاد ادارهء سـالم وتحقـق اصلاحــات در سيسـتم ادارى كشور تدابير لازم را اتخاذ نمايد. ادارة اجراآت خـود را با بى طرفى كامل

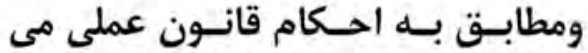

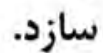
"محمـــــــادر هوتـك " رييس بـورد تعيينات كميسيون مسـتقل اصلاحات ادارى كفت:" بر اساس قانون اساسى، اداره هاى خدمات ملكسى بايد بى طرف باشـند و در بورد

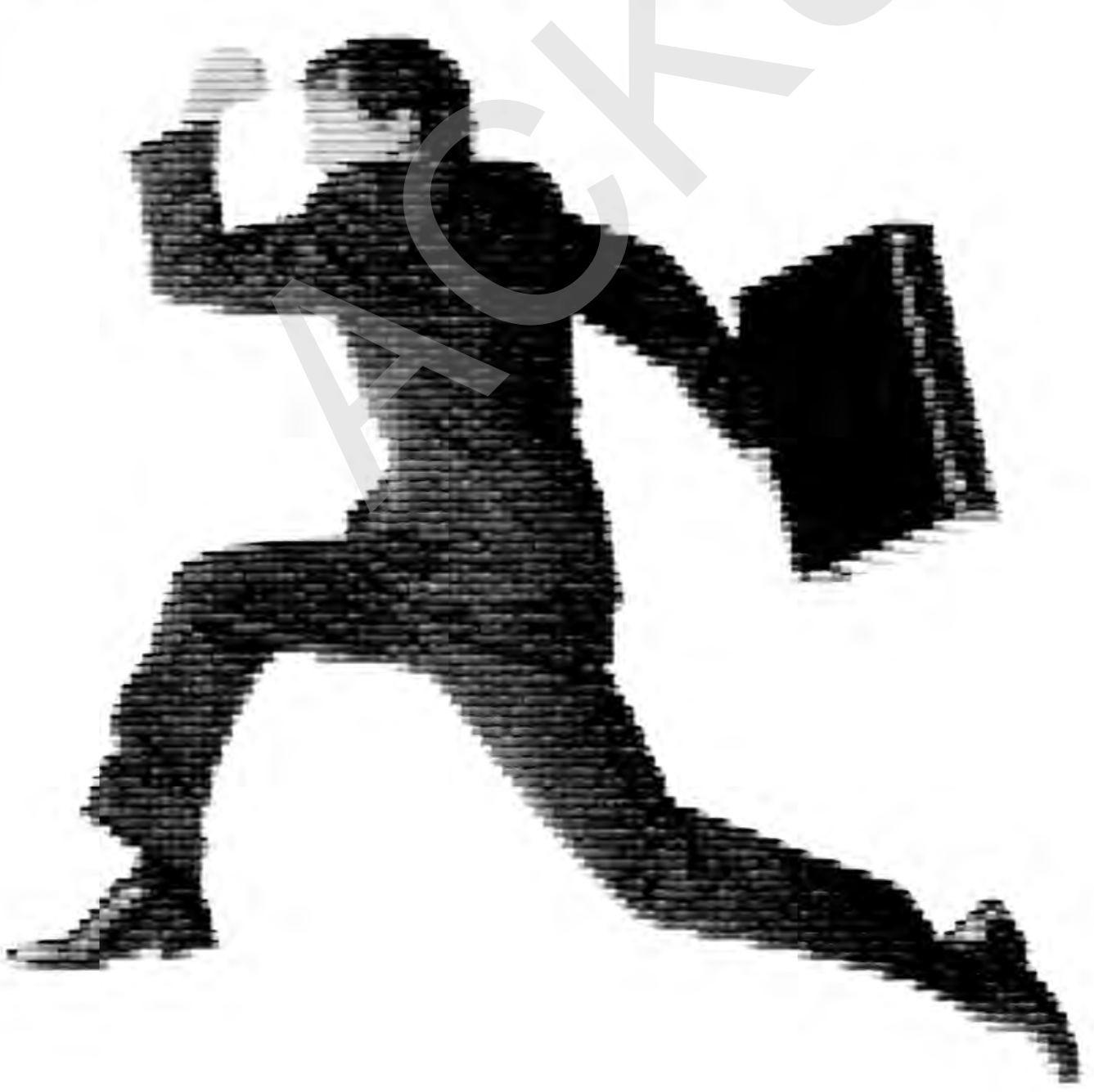




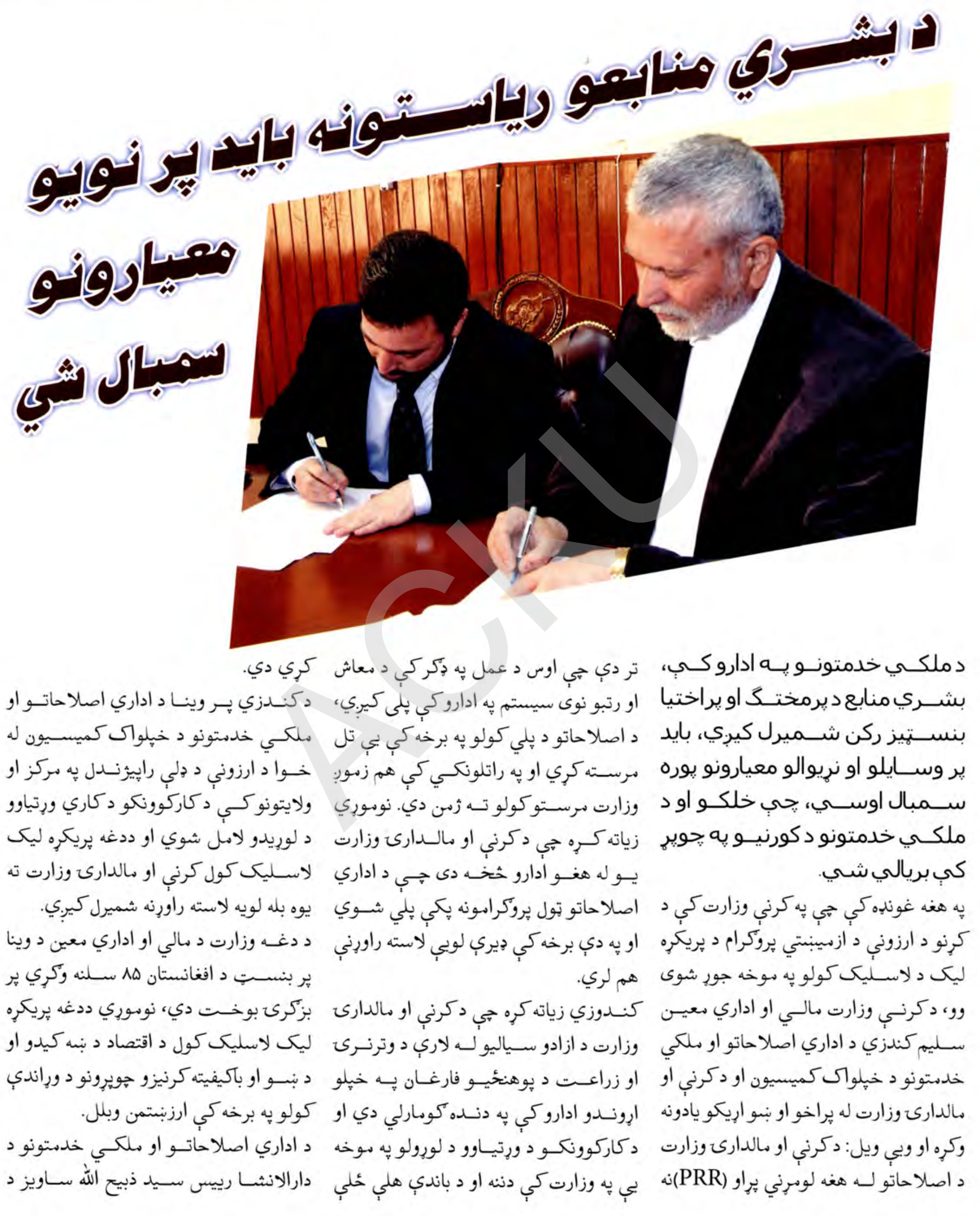




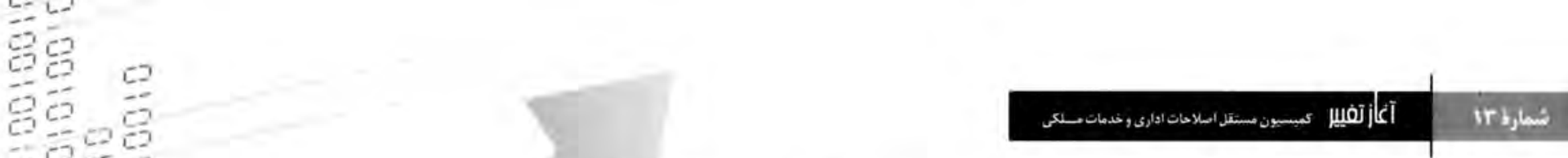

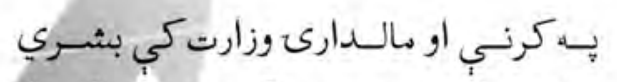

ارزوني د دلي معرفي كول، د اصلاحاتو د

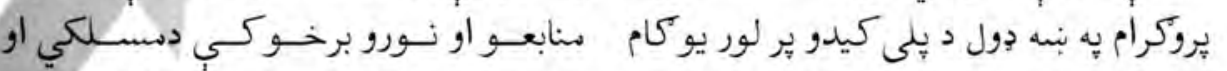

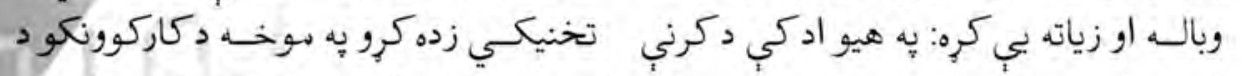

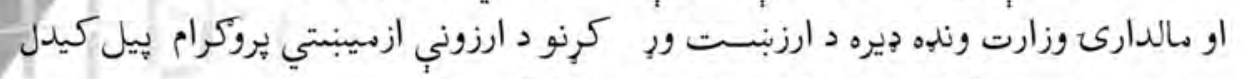

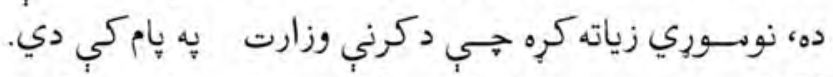

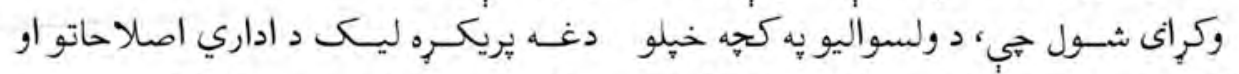

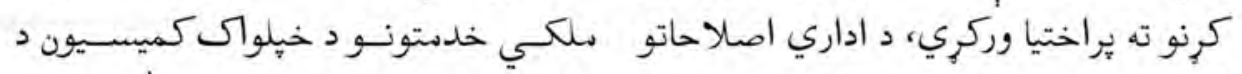

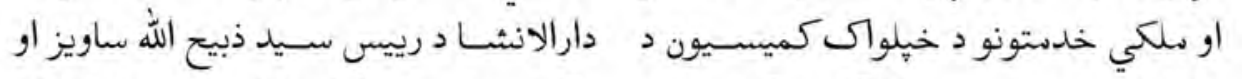

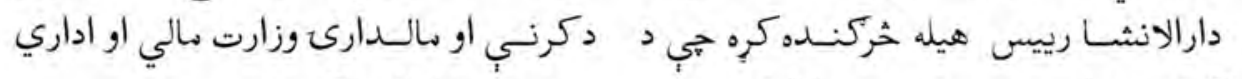

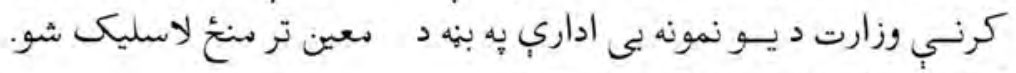

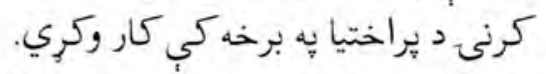

محمد فاروق يوبل ثبا زين: فيض الله صافى
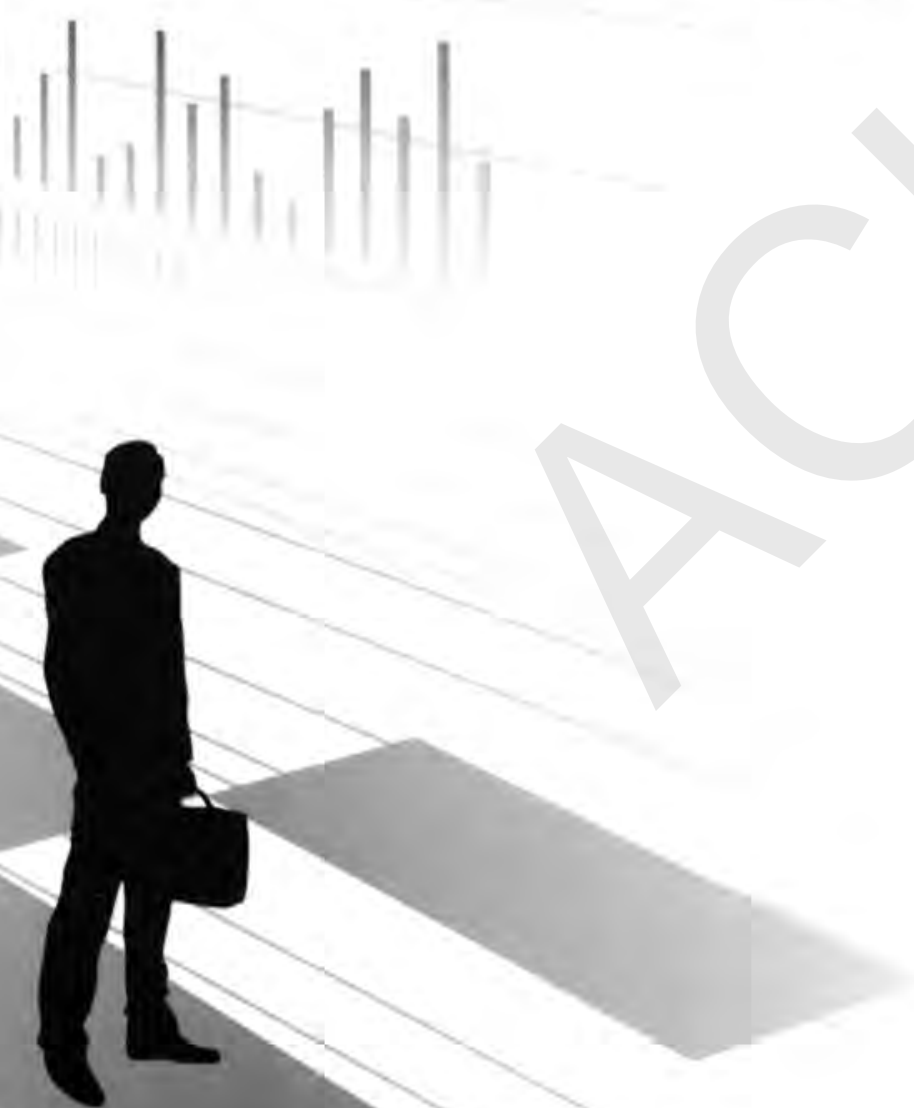


\section{.

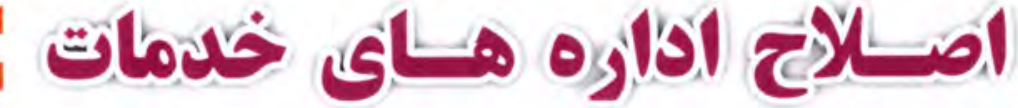

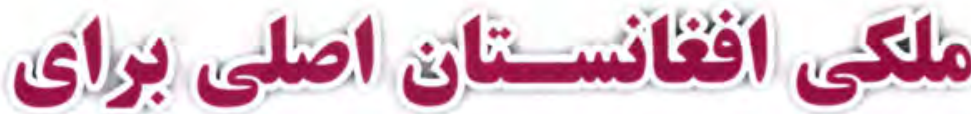

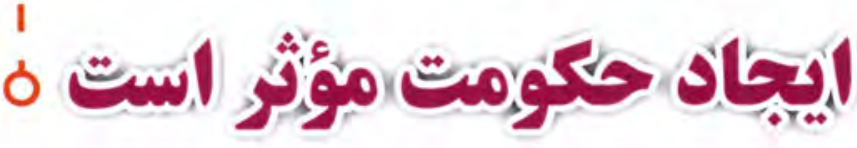

كفتكوبىى با راحله "هاتتنر صدبقى" مiتناور ارتنتد كميسيون دستقل اصلاحات ادارى و خدمات دلكى

در اين مدت انجام شــده و يرسش هاى ديكُ ازاين دست رادر كَفت و كويى با "راحله

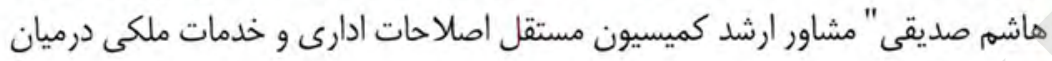
كذاشته ايم كه مى خوانيد:

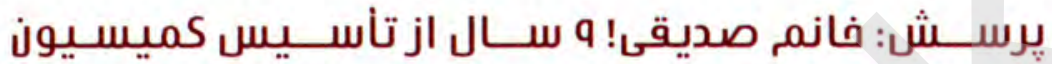

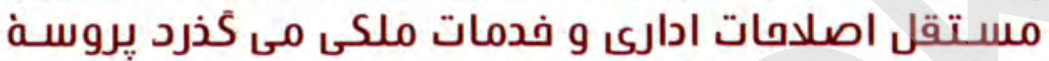

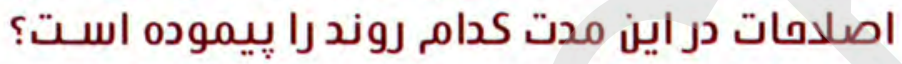

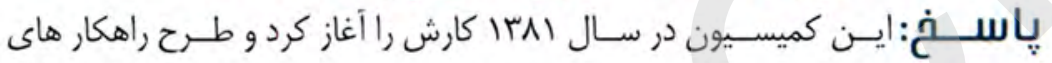

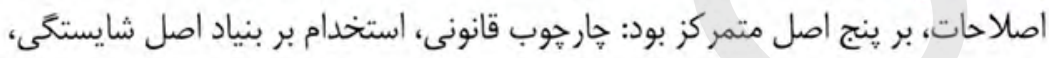

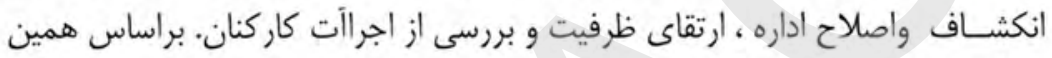

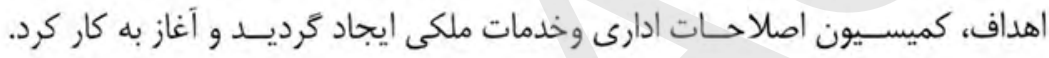

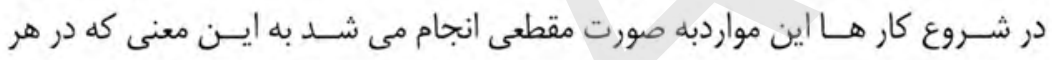

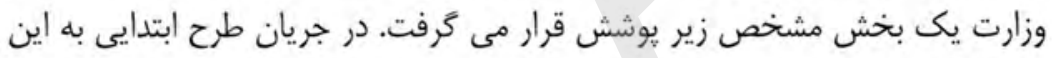

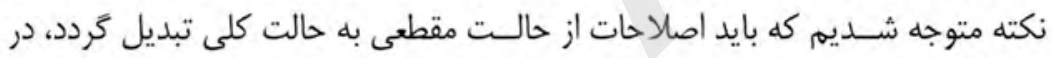

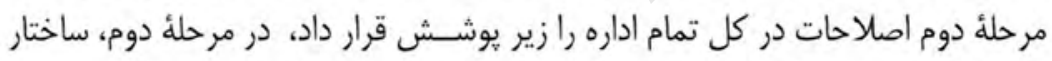

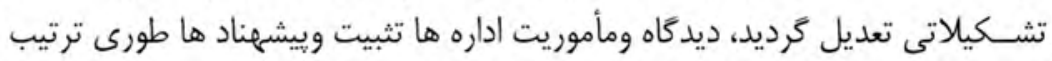

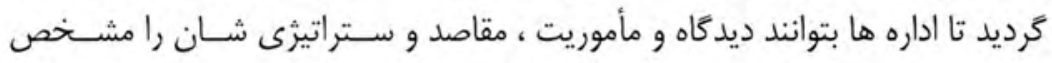

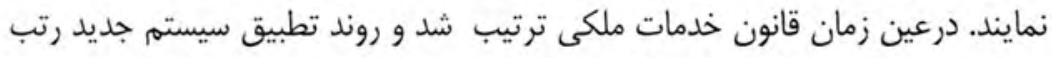

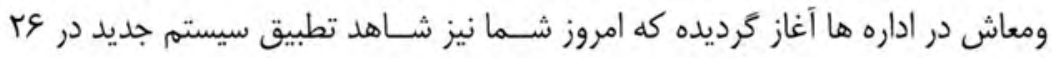

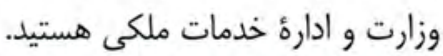

يرسـش: همان طوركه شـما دركفته هاى تان اشـاره كرديد

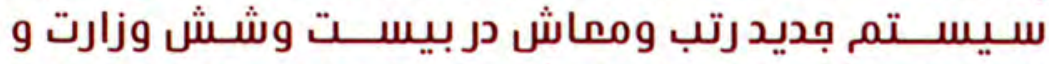

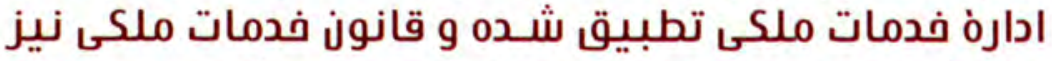

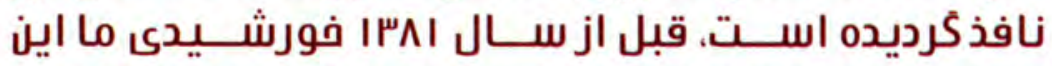

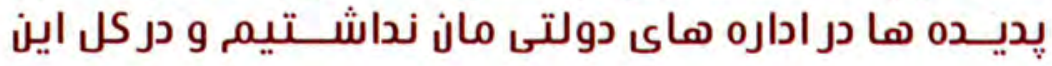

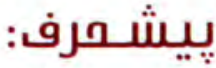

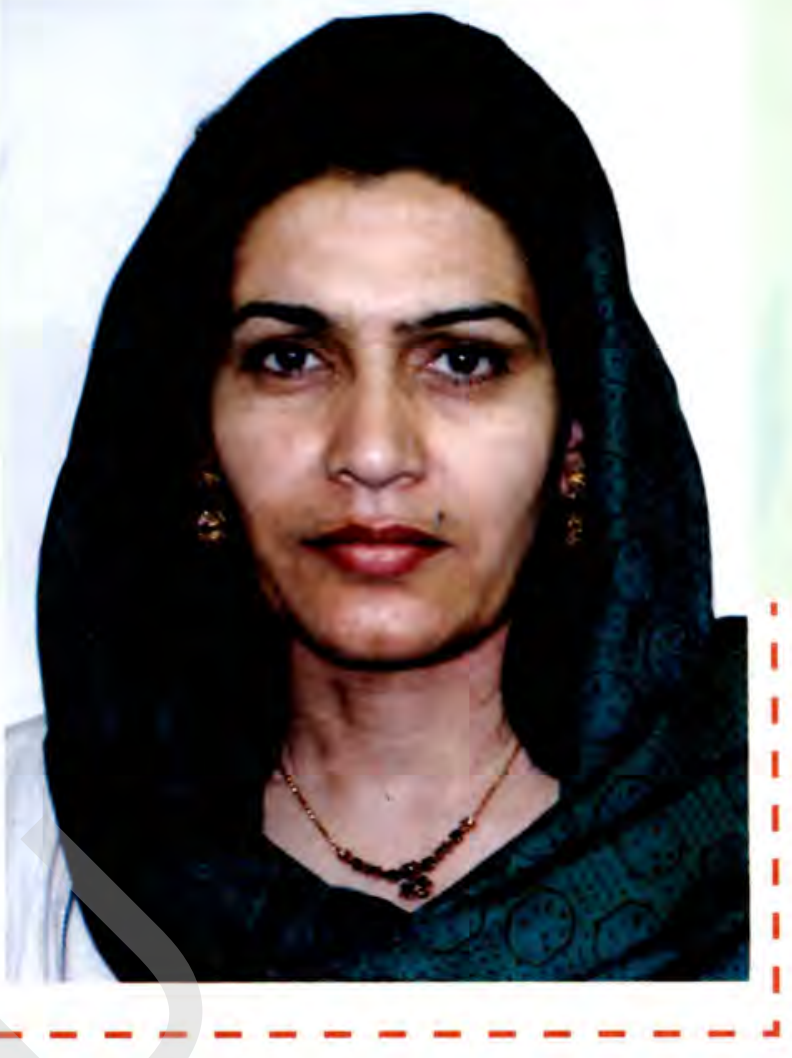
حندين دهه ناآرامى هاى دوامدار و شــرايط نا به سامان در

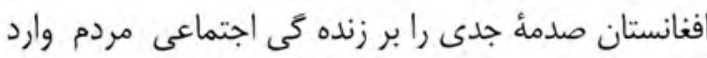

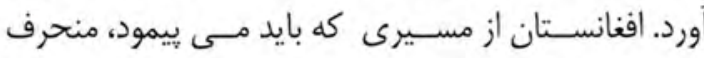

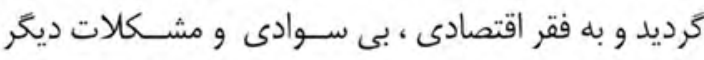

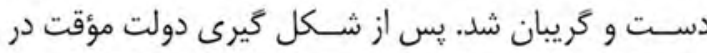

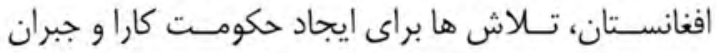

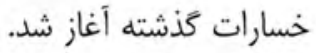
ايجاد كميسـيون مستقل اصلاحات ادارى و خدمات ملكى إنى

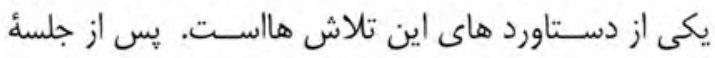

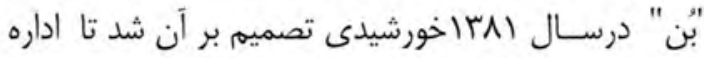

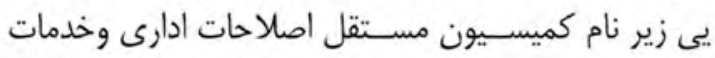

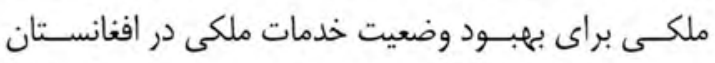

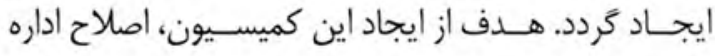

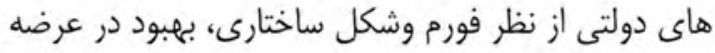

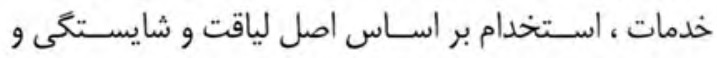
مسـايل ديكرى كه در اداره ومديريت مهرم تلقى مى شود،

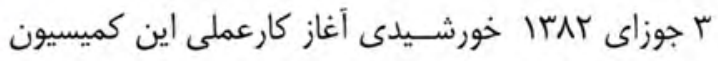

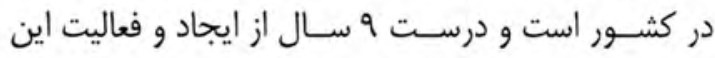

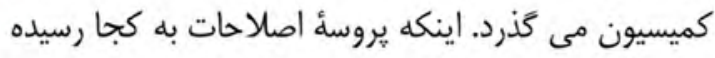

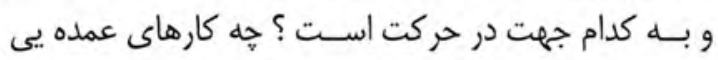


تنها د رسطح خدماتى خلاصه مى شد. با تطبيق

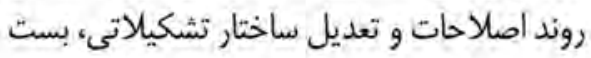
هاى يايين رتبه از بين مى رود و وبيشَّتر كاركنان

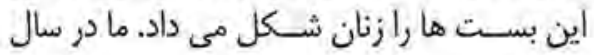

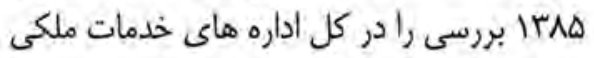

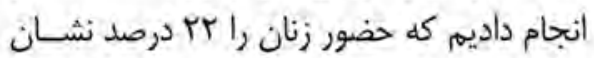

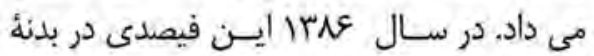
خدمات ملكى به \لا در صد تقليل يافت. درسال

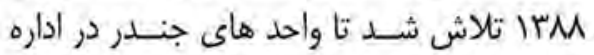
هاى دولتى در سـاختار تشكيلاتى شامل كردند

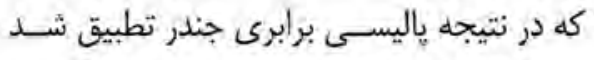

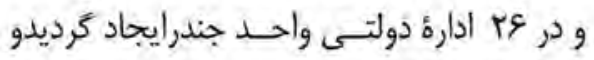
بــه همان ميزان فيصدى حضور زنان نيز در اين اداره ها بلند رفت مان ميزان فيصل

يرسش فيصــدى فضور زنـان در فدمات

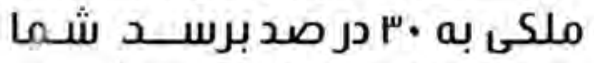

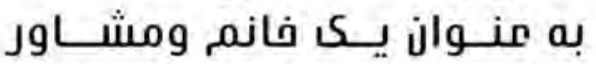

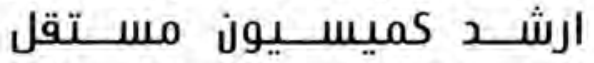
اصلافات ادارى و فدمات ملكى.

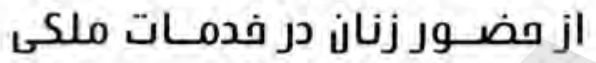

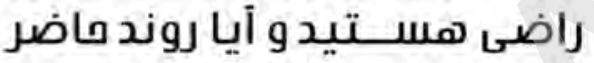

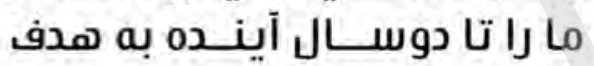
مان مى رساند؟

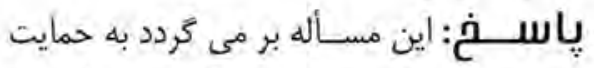

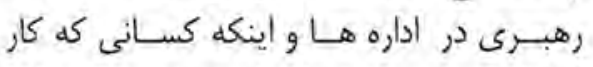

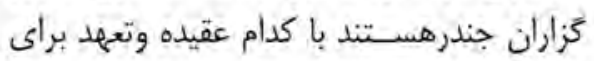

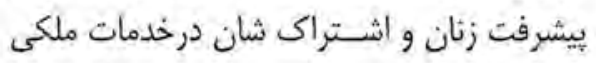

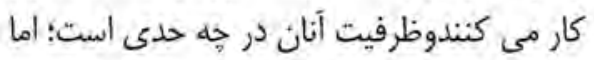

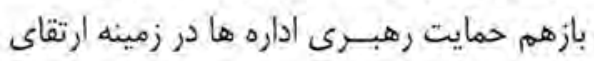

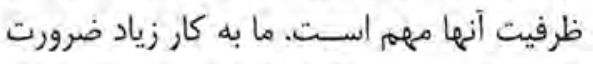

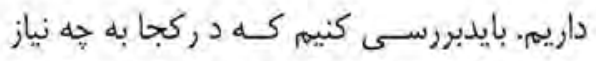

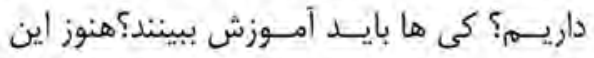

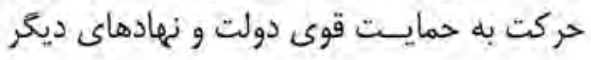

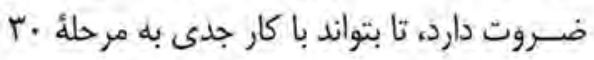
درصدى آن برسد. كفتكو: هادى رويش - كا
كه شـــا يـاد آورى نموديـد در

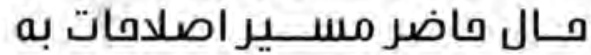

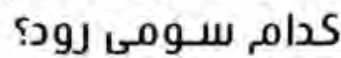

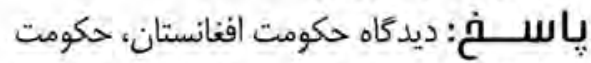

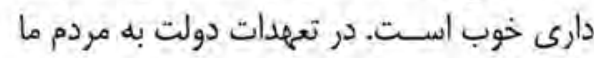
براى ايجاد حكومت دارى خوب، متعهد هستيم. مبارزه با فسـاد ادارى، رشــاقداقتصادى و و مبارزه

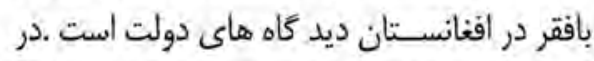

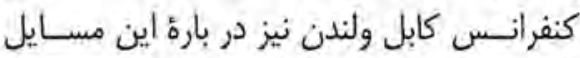

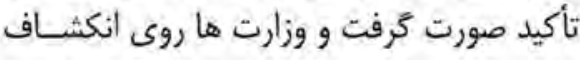

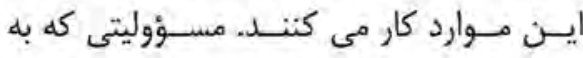

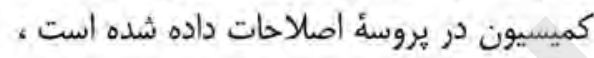
اصلاح اداره هاى خدمات ملكى افغانستان براى دواى

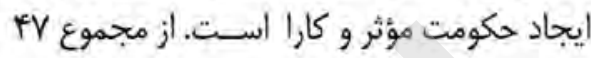

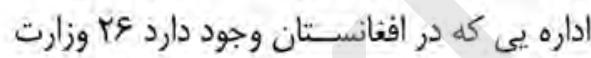

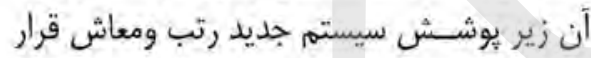
كرفته و كار درمورد اداره هاي ديخر جريان دارد. كميسـيون اصلاحات ادارى در تطبيق سيستم رتسب ومعاش به تفويض صلاحيـت به رهبرى

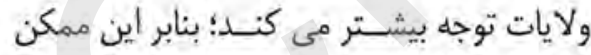

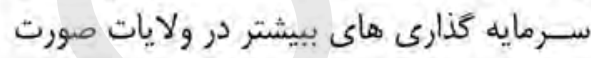

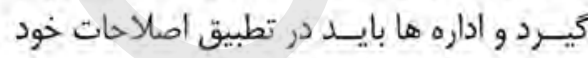
شان مالك اصلى اين يروسه باشند. يرســـش: كففته مى شـود مضور

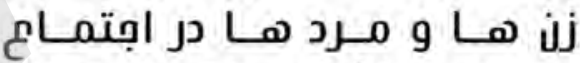
مسـاوى باشـــد ، با توبه به اين

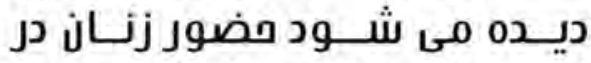
اداره هاى دولتى دركذشـــه بنابر

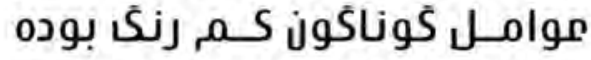
است. يكى از اهداف كميسـيون اصلافـات ادارى، مضورييشـــر

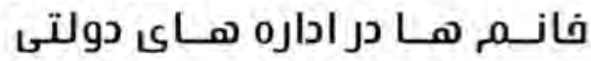

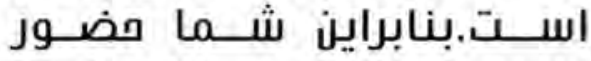
بانوان را در فدمات ملكى پِكونه ارزيابى مى نماييد؟

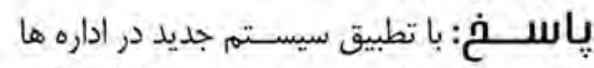

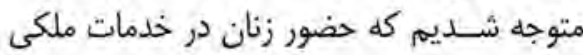

كار يك يديدة جديد اســـ. با آن

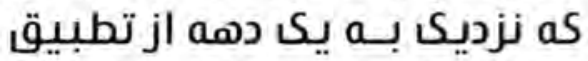

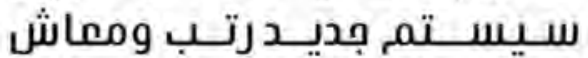
مى كذرد شـــــا هِ تفيـير مثبتى زادر وضميت اداره هاى فدمات ملكى مــ بينيد و هه تفاوتى را بــا اداره هايــــ كه قبل از ســـال

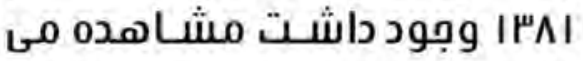
نمايبد؟

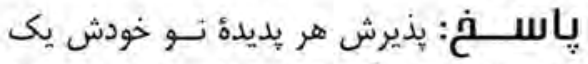

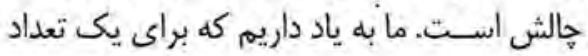

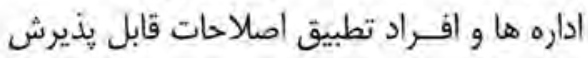

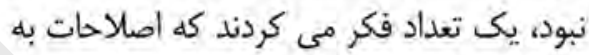
نفع اداره ها نخواهد بود و در واقع مانعى برسـر

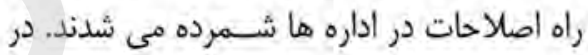

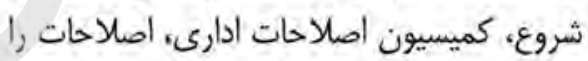

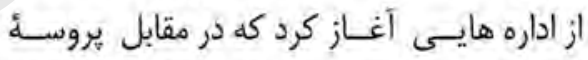
اصلاحات مقاومع نمسى كردند. از طرف ديكر

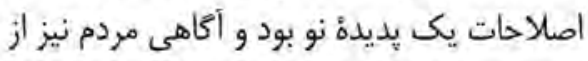

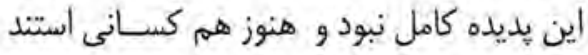

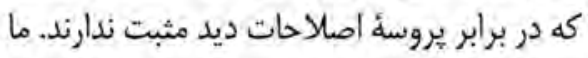

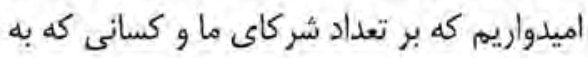
اصلاحات با ديد مثبت مي نكرند افزوده كردد كرد

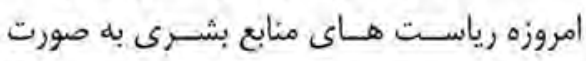
سيستماتيك ( سـامانمند ) و اركانيك (أندامور)

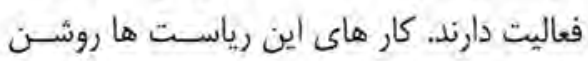

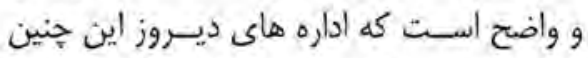

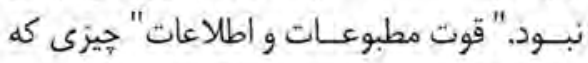
ما را براى رسـيدن به شــركاى مان كمكى مي في

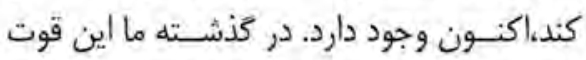

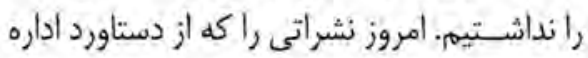

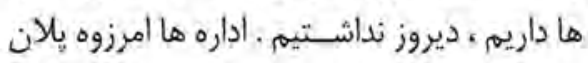
دارند، لايحه وظايف مشخص است، كزارش كار

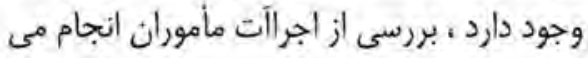
شــود، اين ها همه يك تغيير مثبت در اداره هـا بران است. - - است يرســـ : با توبه به مســـايلى 


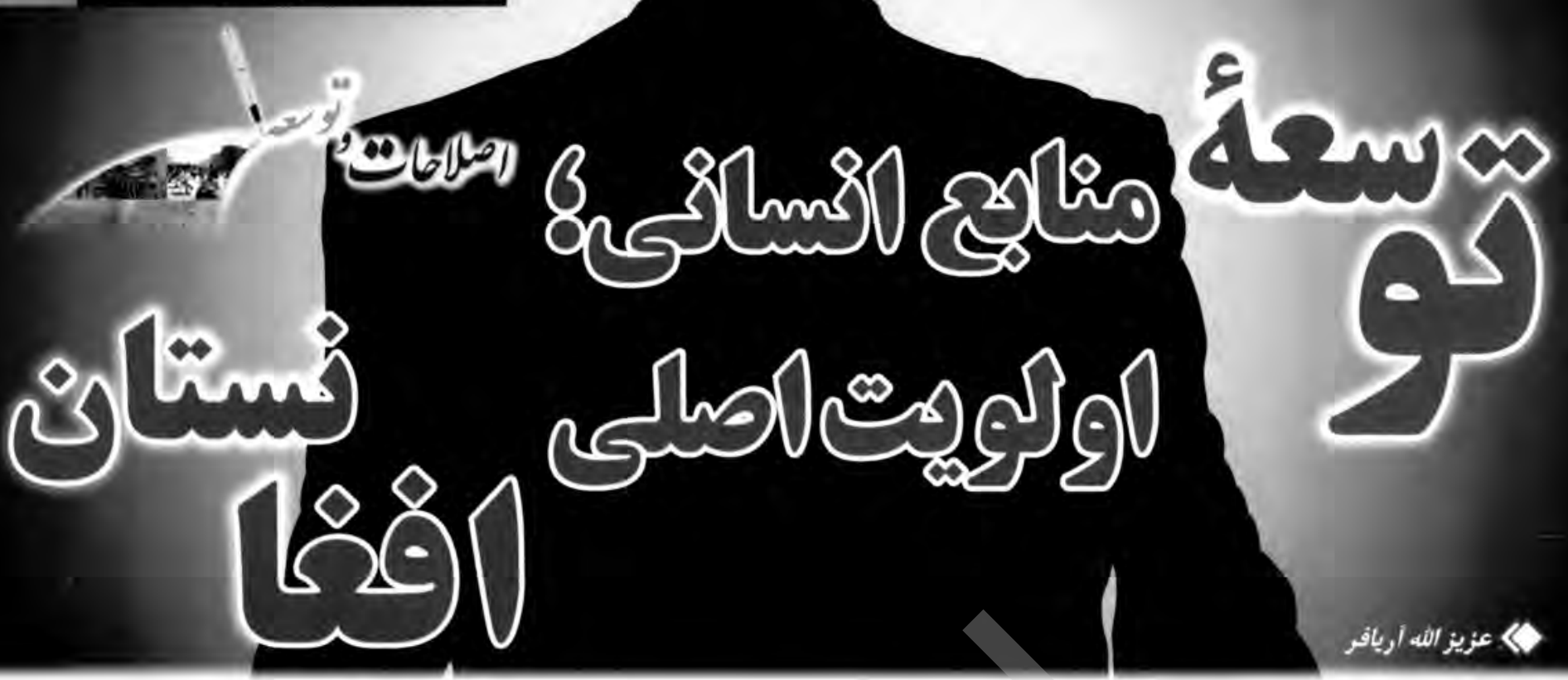

خواهد شد. و حتى تصور توسعه در يك هنين

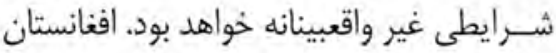

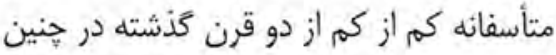

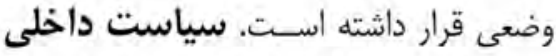

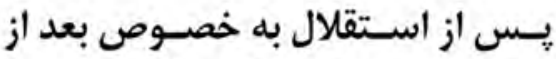

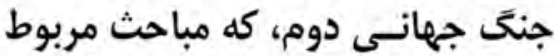

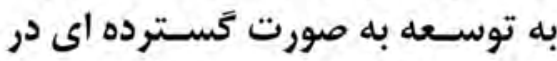

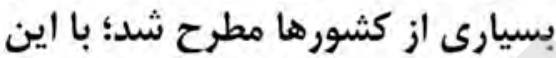
مسائل بيخًانه بود؛ و در بسياري

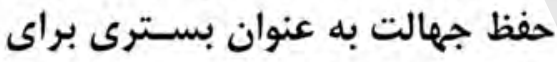

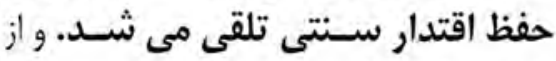

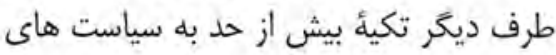

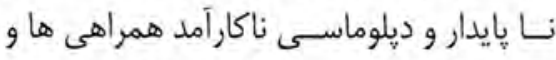
حمايت هاى متداوم بين المللى را از اين كشور

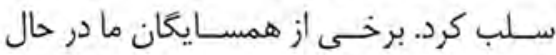
حاضر نيز به موجوديت و مشروعيت ما احترام

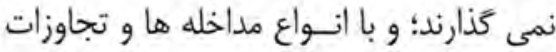
بزركترين فرصت هاى افغانستان براى توسعه

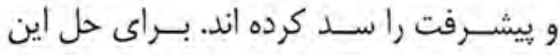
مشــكل در حال حاضر ما فقط يك راه داريم:

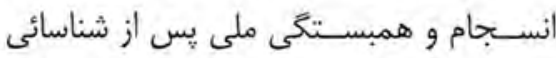
دشمنان و درى تهديدهاى بزرى منطقه ائ. بناءُ موقعيت جغرافياى سياسى و اقتصادى در
تكنولــوزى، قدرت و اعتبار دسـت يافته اند؟ هرا

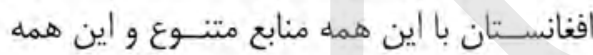
حمايت هاى بين المللى؛ كماكان در حالت عقب مناب

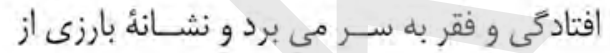
شـكلكيرى يك توسعه هايدار در اين جا به ظهور نرسيده است؟ يا مسائل ديكرى ست، كه جريان

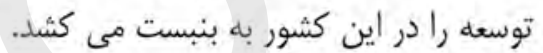

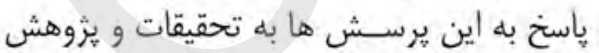

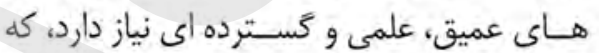
بايسـد صاحب نظران و دانشــمندان مربوط به آن آن بيردازند؛ اما براى باز شدن بيشتر اين مبحث لازي ماند

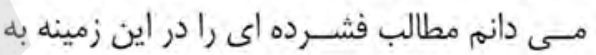
عرض برسانه: أ. اولتر از همه يذيرفتن مشروعيت و موجوديت

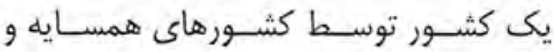
كشــورهاى بزرى جهانى در راسـتاى فراهم شــن زمينه هاى توسـعه حياتى ست. هركاه

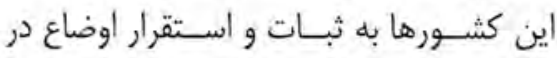
كشور احترام نغذارند؛ طبيعى است، كه خهنين

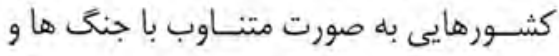
بحران هاى متنوع از نوع درونى و يا بيرونى آن دركير مى شوند. در جنين وضع تمام امكانات

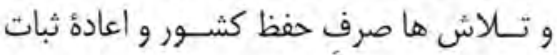

مطابق ديدكاه ســتى در افغتانسـتان مبناء اصلى

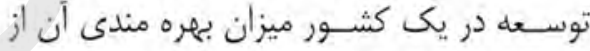

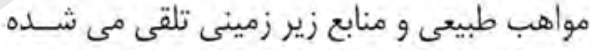

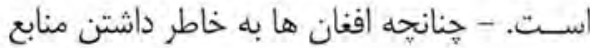
معدنى سرشار همشــهـ افتخار مى كتند.-- هر خند اين منابع در شــكلدهى و يِيشبرد جريان توسعله

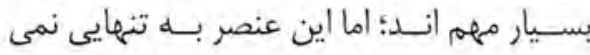

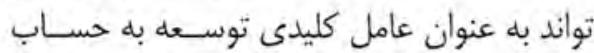

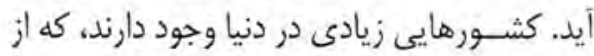
منابع طبيعى اندكى برخوردار اند؛ اما تمام مراحل

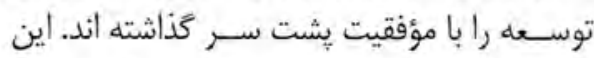
كشورها در حال حاضر از مؤفق ترين كشورها در زمينه هاى برنامه ريزى و اجراء توسـعه به شمار

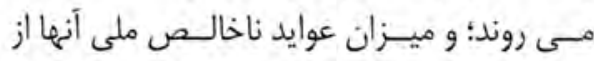

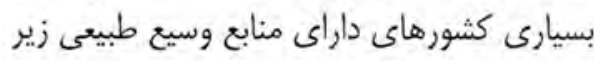

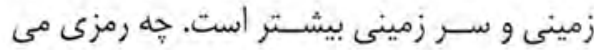

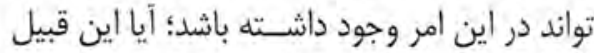
كشورها در موقعيت جغر افيايى مناسب ترى قرار

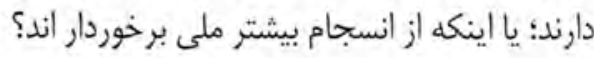

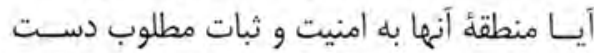

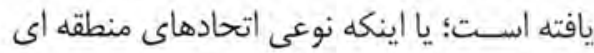

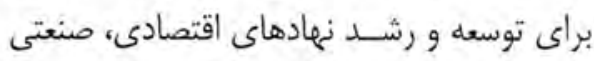
و تجارتى وجود دارند؟ آنها جُّونه به اين ثروت، 
تواند ما را به نتايج اين بحث نزديك سازد.

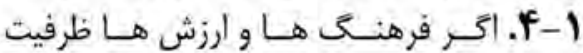
شـكلدهى حنين بسـترهايى را نداشـته باشند:

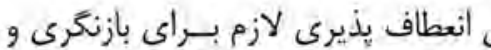

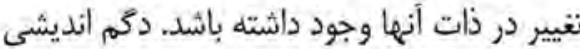
و تحجر هيحگًاه جريان هاى نوگرايانه را بر نمى تأبد و دايمم بر برخى از عادات و رســوم سنكواره

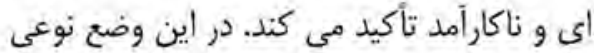
مقاومست منفى در برابر بديــــه هاى جديد ايجاد مى شود، كه كَاه به جنى و خشونت مى انجامد.

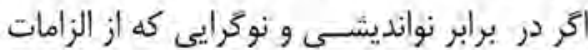
اصلى توسـعه به شمار مى آيند، موانع ايجاد شود طبيعى أست، كه زمينه هاى توسعله واقعى بسيار محدود خواهد بود.

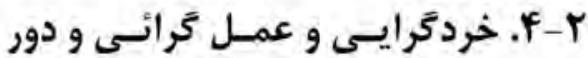

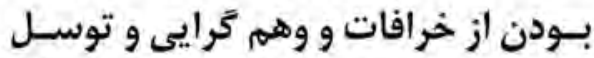

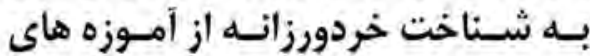
اصيل دينى مى تواند بســترهاى مناسبى

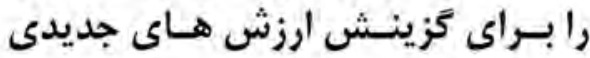

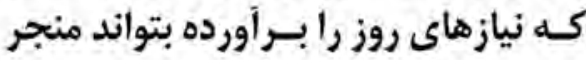
شــود. در كشــور مـا متأسـفانه در وضعى كه ونه

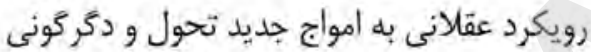

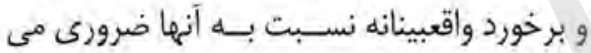

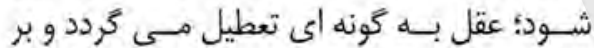
مبائى غيرعقلايى تأكيد مى شود.

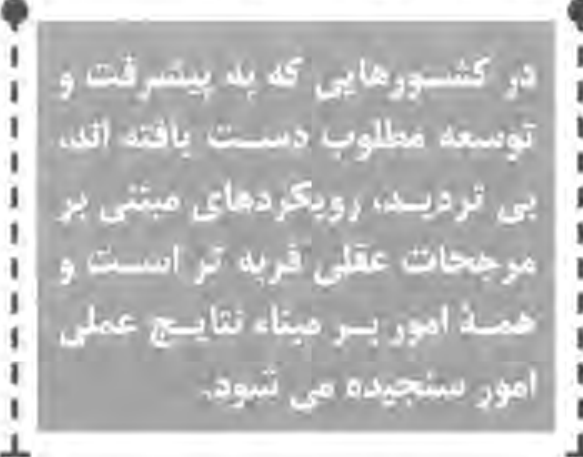

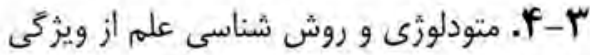

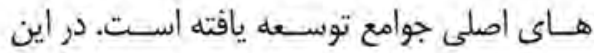

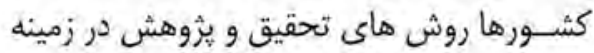

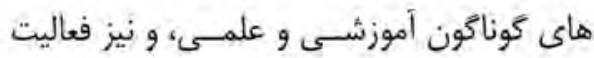

منطقه ايى نظير ياكســتان در إين زمينه، حِشم انداز مؤفقيت افغانســان و جامعله جهانى هنوز در هاله ايى از ابهام قرار دارد. طبيعى است، كه

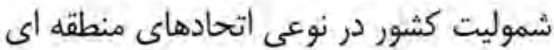

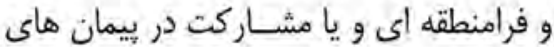

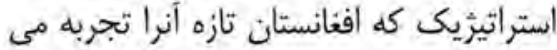
كند؛ نيز بسـيار مهم و حياتى اسـت؛ هرا كه توسـعه به معناى واقعى كلمه يكى امر فراملى اسـت و بدون توافق كشورهاى ذيربط امكان يذير نيست. تأخير در تحقق يروزة انتقال كاز از تركمثنستان

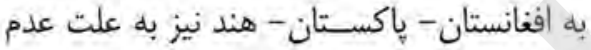

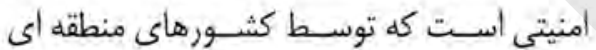
همجون ايران و ياكسـتان دامن زده مي شــود.

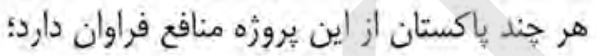

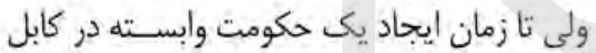
از همكارى براى تأهين امنيع افغانستان و تطبق

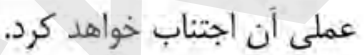
موجوديت همكارى هاى منطقه اي براى توسعأ

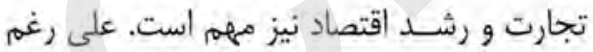

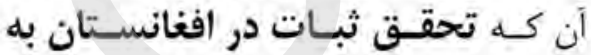

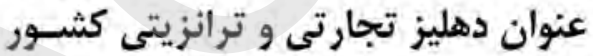
هاي آسـيايى مى تواند در جهيت توسعه

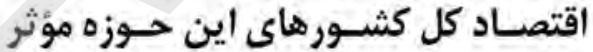
باشد؛ اما به دليل بازى هاى كلان قدرت هاى

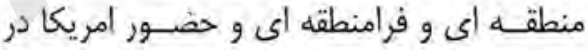

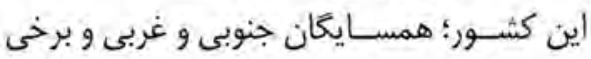
كشورهاى منطقه هنوز بر تداوم جنى تأكيد مئى

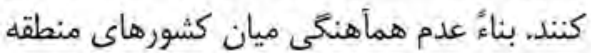

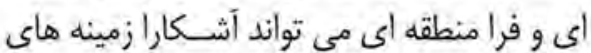
توسعه رادر اين حوزه به مخاطره اندازد.

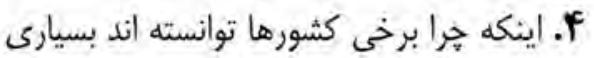

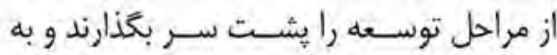

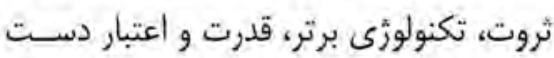

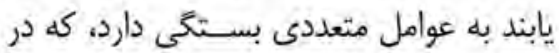

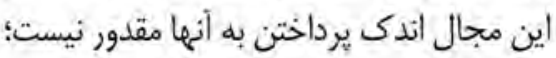

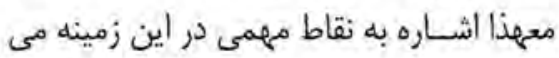

زمينه هاى توسعه بسيار مرهم است r. موجوديث انسجام ملى نيز براى مؤفق شدن مئن جريان توسعه و رشد اقتصادى حياتى است. بله هر ميزانى كه شـهروندان يا به تعبير قديمى تر اتباع يكى كثــور نسبت به

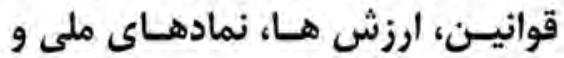
ســرزمين آباييى شـان تعلق و احترام

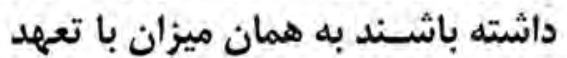

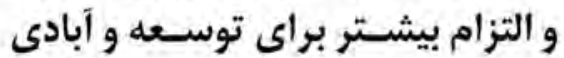
كثور خويش تلاش مى نمايند. انسجام

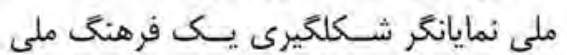

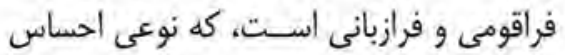
مسؤوليت جمعى را در برابر كشور و ملت خلق

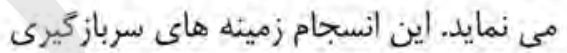

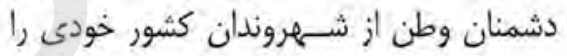

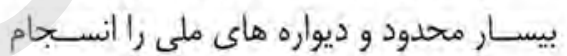

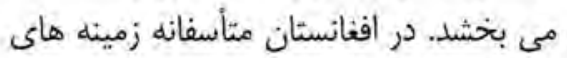
فراوانى براى استفاده از اتباع اين كشور توسط داسطان دشمنان منطقه اي أن وجود دارد، كه از فقدان

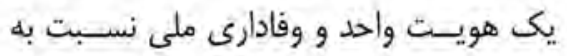
سرزمين خودى ناشى مى شود. تحقق توسـعه و يا هر تحول بنيادى ديكر بلون

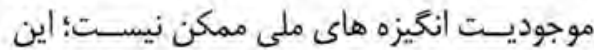

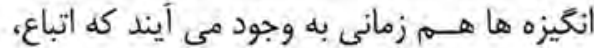
كشور را خانه كلان خود فرض نمايند و نسبت به به به بند آن عشق بورزند. ז. همجِنانى كه امنيت، يايه و وِيشزمينه

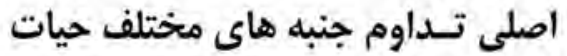

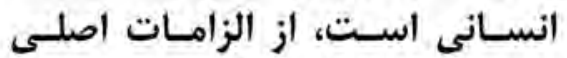

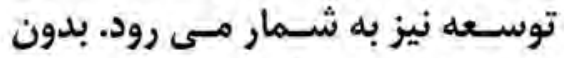

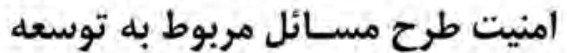

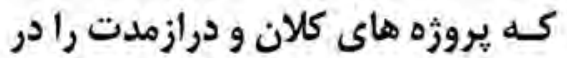
بر مى كيرد؛ غير واقعبيينانه اسـت. به به همين دليل است، كه حجم عظيم كمك هاى

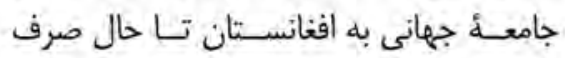

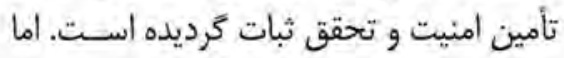

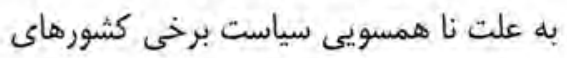


انسانى است. تمام منابع ديخر فرع بر اين منبع اســ. در حال حاضر قدرت كشورها از يك جهت بر اسـاس بهره مندى أنها

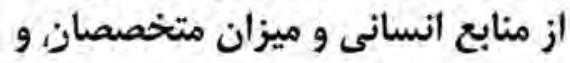

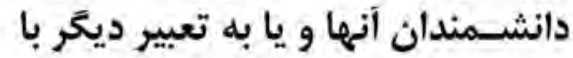
در نظرداشـت مغزهايى كـهـ در اختيار

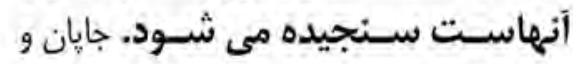
تركيه از كمترين منابع زيرزمينى برخوردار اندا:

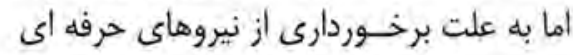

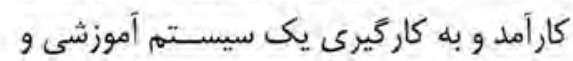

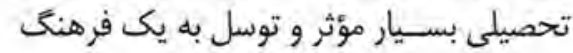

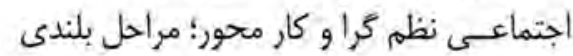
از توسعه و فرهنى توسعه را تجربه مي كنثلد.

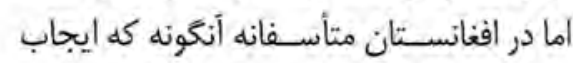
مسى نمايد به اين أمر اساسـى و مهم برداخته نشــده استــ و مثابع فرعى ديخــر كماكان

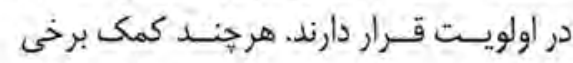
كشـــورها به ويزه هند در زمينه تربيئه نيروهاى انسانى و قراردادن فرصت هاى تحصيلى براى هئ هن

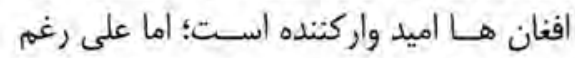
اميد به نتايج بسـيار مؤثر إيـن كمك ها بايد اذعان كرد كه با در نظرداشت نيازهاى موجود

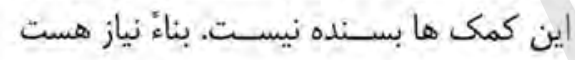

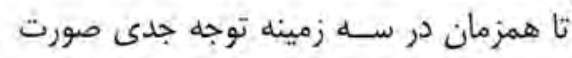

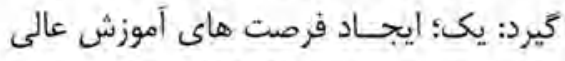
ملدرن و استثدرد در داخل افغانستان، همزمان هان با تمركز بر جذب بيشتر بورس هاى تحصيلى

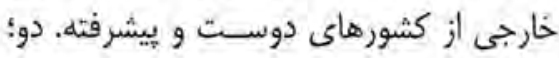

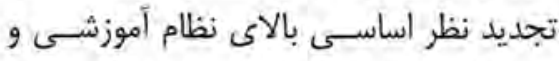

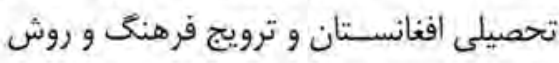
هاى ييشَـرفته در اين زمينه هــا؛ تا با ترويج

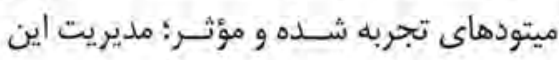

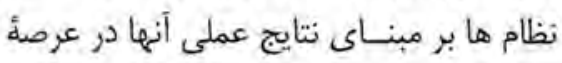

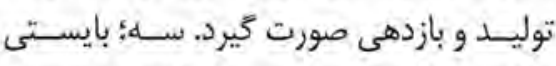

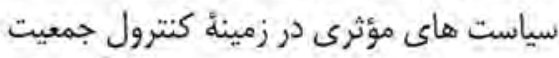
در نظر كرفته شـود؛ زيرا هينانهه قبلاً اشتـاره

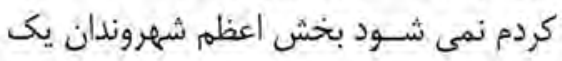

و تداخـل غير ضـرورى نهادهـا در امور يكديكر از جملة عواملى است كه جريان

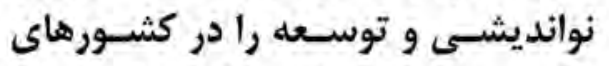
عقـب مانده تضعيف مي كند. لازم اســـ

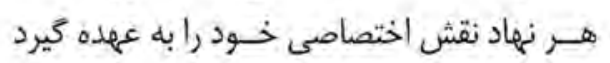

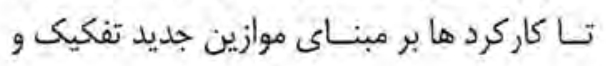
نوعى نظمه نوين به وجود آيد.

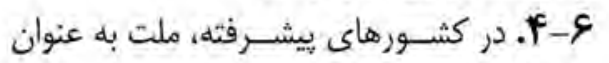
تنها نهاد معتبر، وحدت بخش، عينى و شـناخته شـــده تلقى مى شـود، كه داراى خصائص نسبتاً قابل اندازه كيرى اسـت. در اين كشــورها اتكاء بــهـ أرمانهاء مثافع و ارزش هاى ملى بلى براى تثبيت

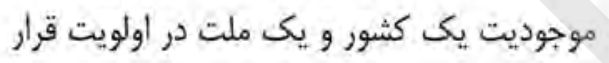

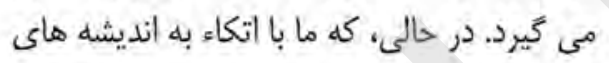

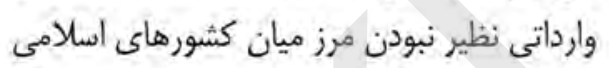
و... شديد ترين آسيب ها را توسط برخى أز همين منين كثــورها متحمل شده ايم. و مساعد ترين زمينه ها كه با حضور جامعل جهانى براى توسعله كشور

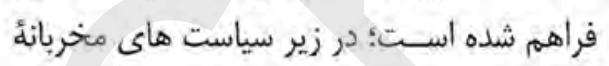

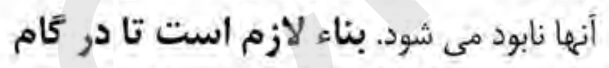

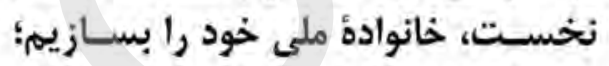

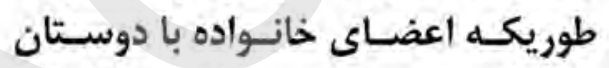

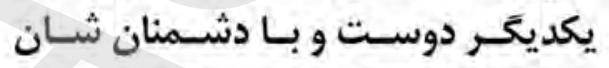
دشمن باشند؛ و هيج باور ديخُى نتواند

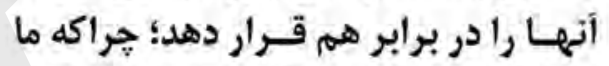
سالهاسـت كه زير تأثير باورهاي واهى اهي

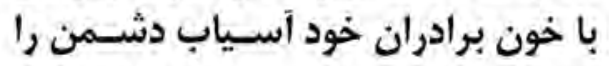
خرخانده ايم. و هميشه به عنوان افزار ديكران

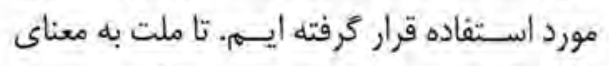
واقعى كلمه شــكل نكيرد؛ هيج تحول و توســـ اى رونما نخواهد شند.

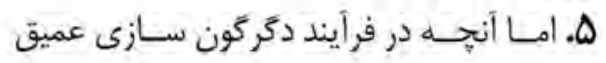
جوامع به خصوص جوامع سـتنى و ايسـتا در راستاى توسعه نقش مهم و كليدى دارد؛ منابع

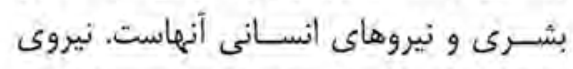

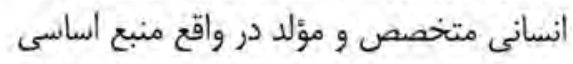

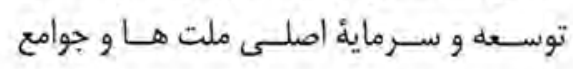

هاى عرصةٌ تكنولـوزَى و توليد به كونهُ منظمى سـاماندهى شده است؛ طوريكه در همهُ اين امور

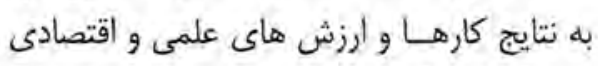

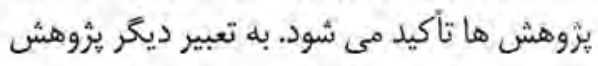

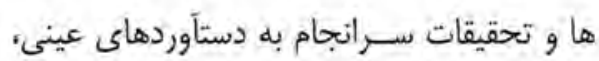
محسوس و كار آمد منتهى مى شوند.

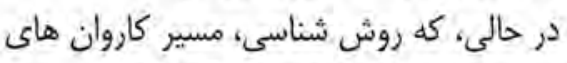

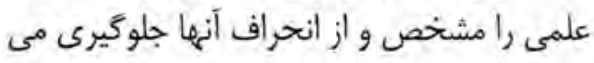

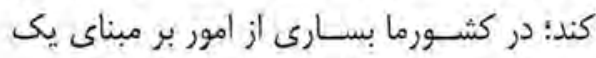
روش تنظيم شده و تجربى استوار نيست. به بيان

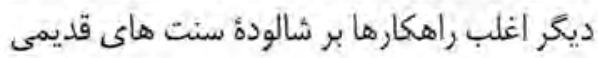
يا تجربه هايى اثبات ناشدة افراد بنا يافته أست.

\section{.}

براى سـاخت بسـترهاى توسعه،

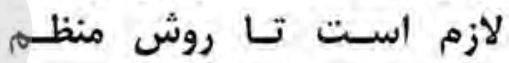
انديشيدن، منظم فراكرفتن، منظم

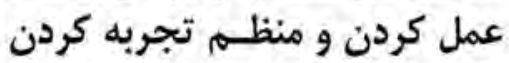

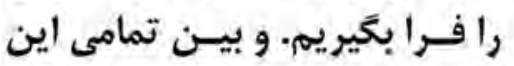

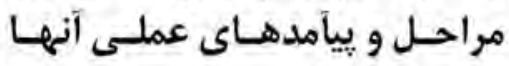
ييوند برقرار كنيم.

كار م

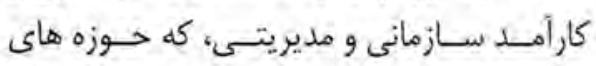

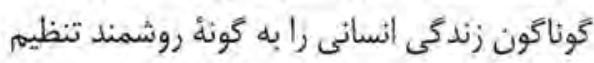

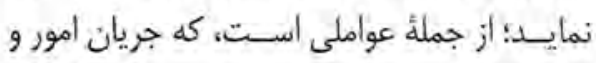
فرآيثد تطبيق توسـعه را سامان مى دهد. إعمال

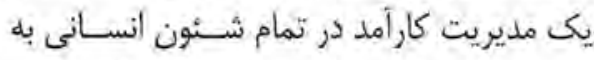

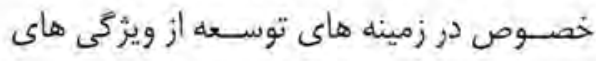

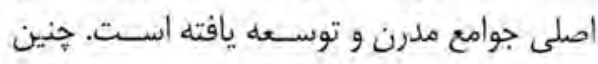

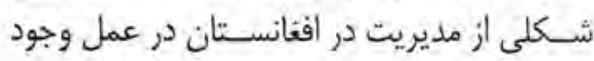

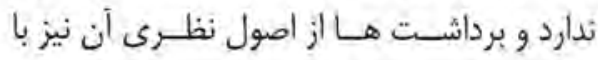
يارادايم هاى متعددى روبروست.

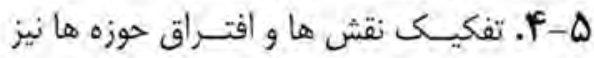

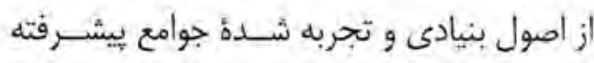

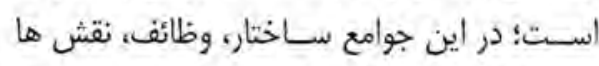

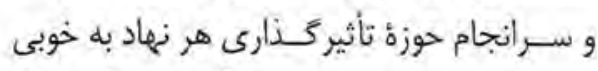
مشـخص شــده أبـت. هم آميزى نقش ها ها 


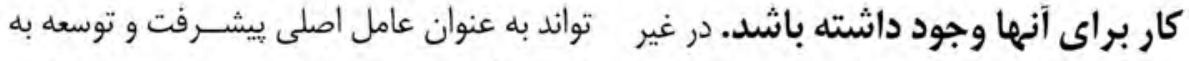

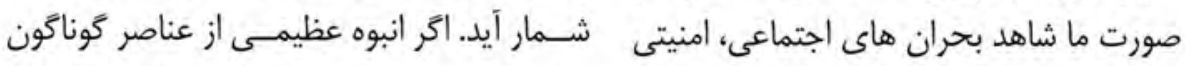

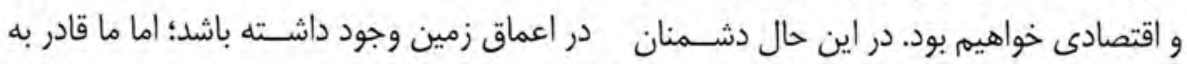

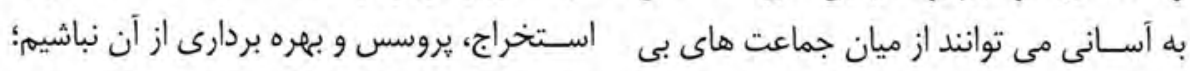

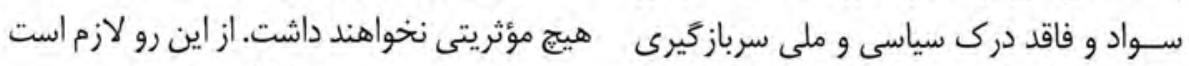

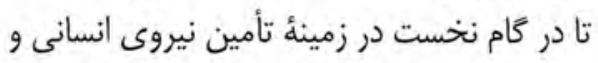

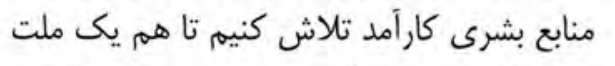

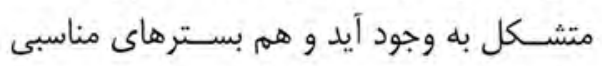
براى توسعه و ترقى در كشور فراهم شود.
كنند و بر ضد منافع وطن استعمال نمايند. كيفيت نفوس و ميزان بهره مندى شهروندان

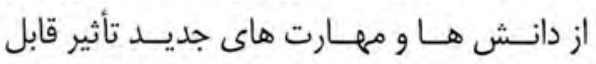

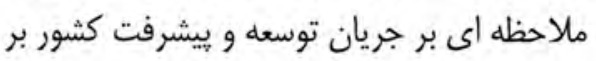

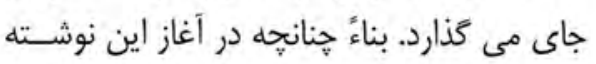
اشاره شد؛ تنها داشتن منابع طبيعى و معدنى نمى جنى
كشور كه عضو يك خانوادة ملى اند، از نعمت

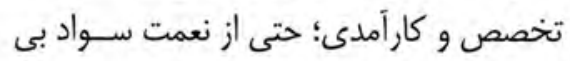
بهره باشــند و فقط بخش كوجكى در يروسئ

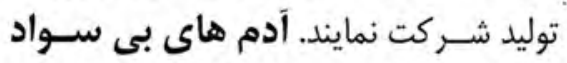

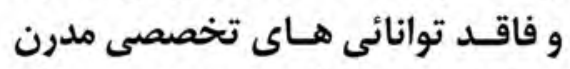

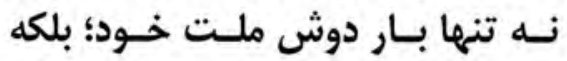
بـار دوش انسـان هاي جوامــع ديكَر

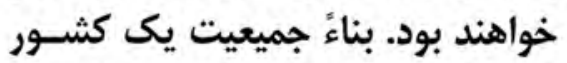
بايد همان قدر باشــد، كـهـ ظرفيت هاء

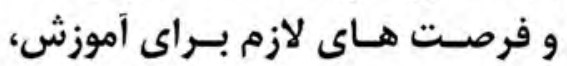

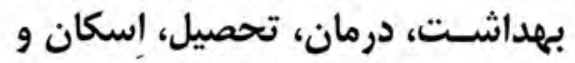




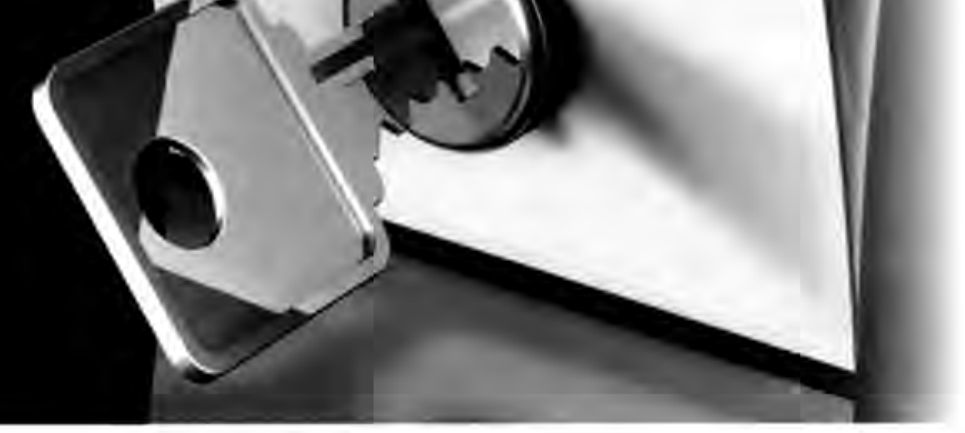

\section{مصالوماتِى}

اساسل تصمتحل

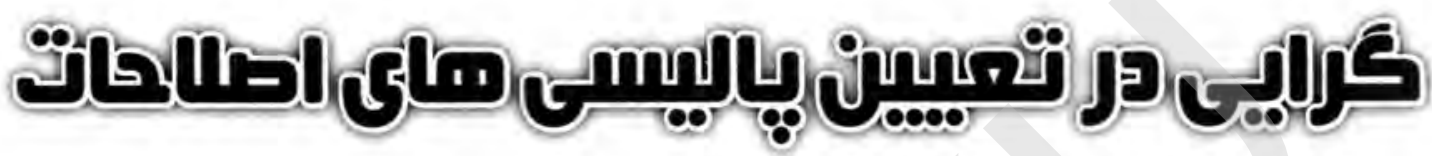

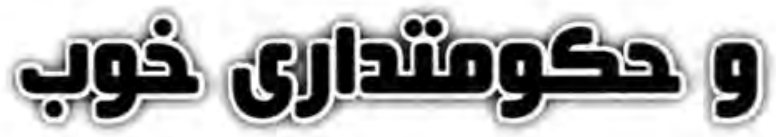

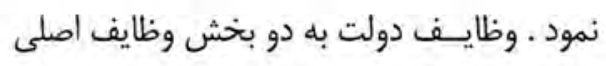

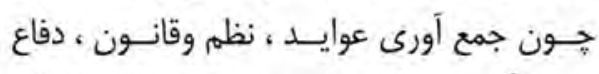

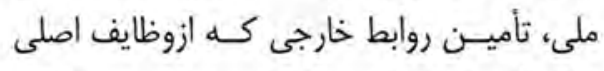

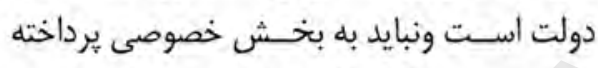

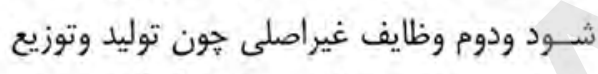

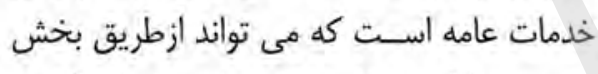

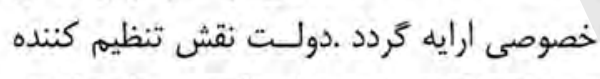

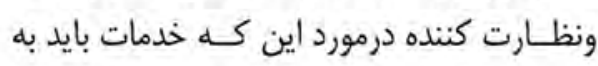

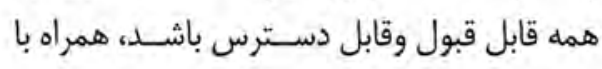

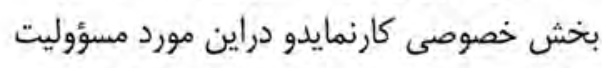

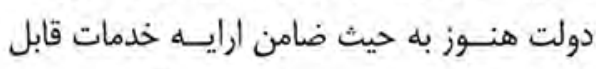

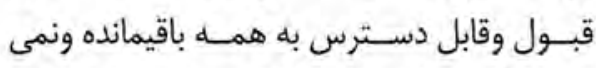

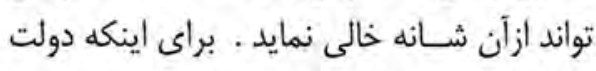

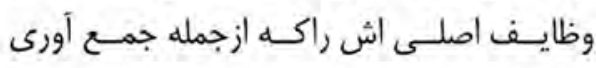

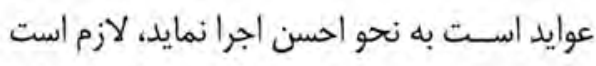

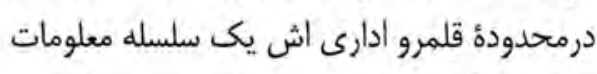

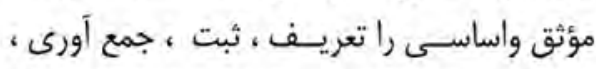

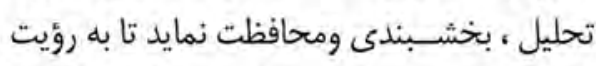

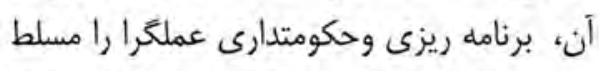

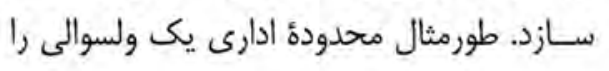

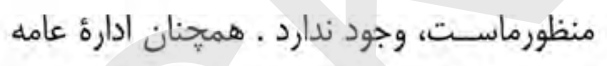

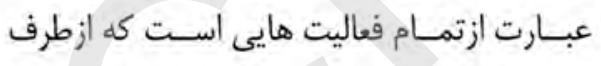

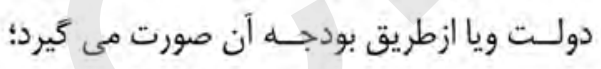

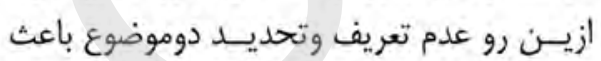

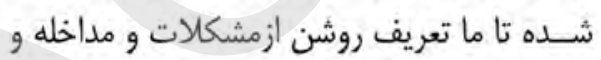
كمى و كيفى برنامه نداشته باشيهم وبا ببود تعريف

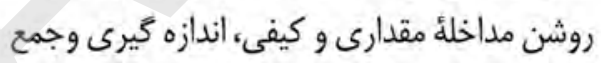

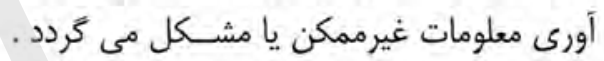

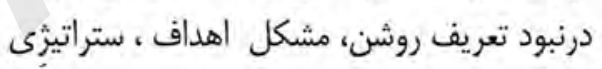

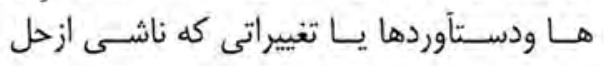

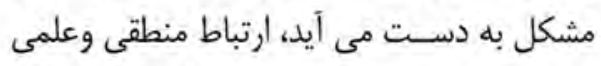

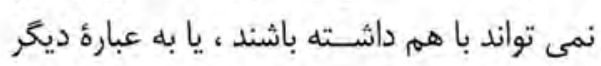

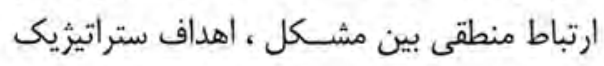

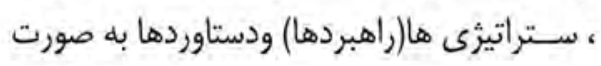

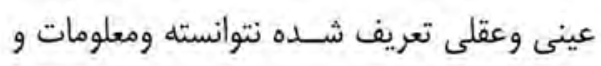

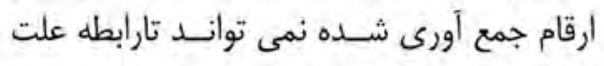

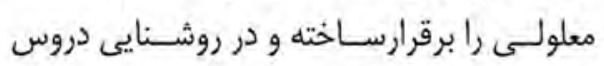

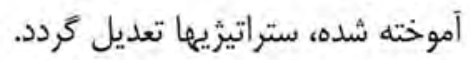

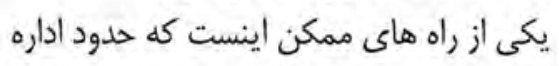

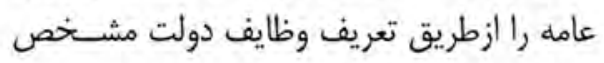

امروز،اصـلاح ادارةٔ عامه درســرلوحه بحث هاى

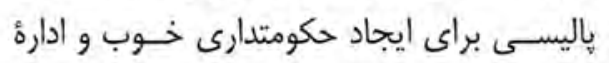

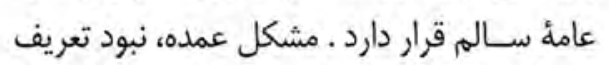

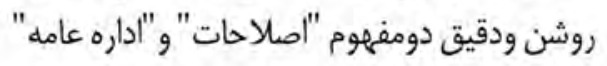

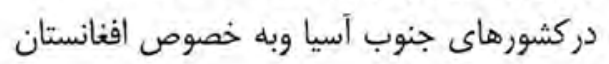

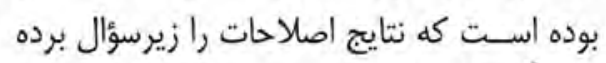

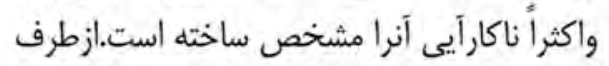

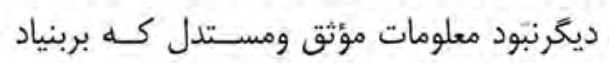

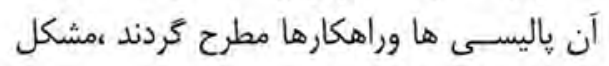

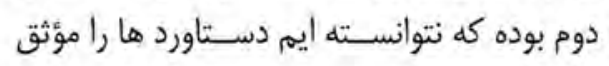
ومستدل سازيم .

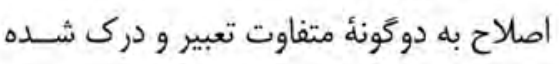

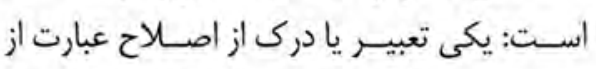

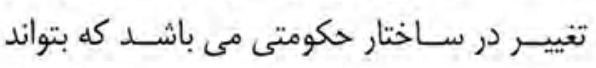

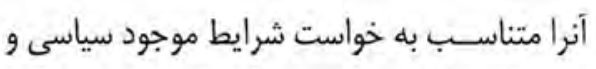

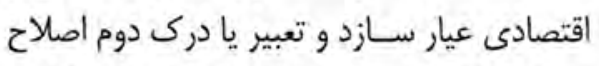

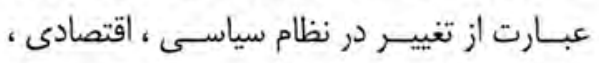

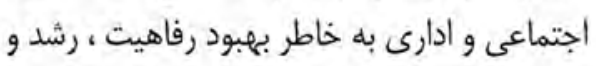
شـكوفايى شر ايط زنده كانى مردم است كه هن هنوز درك همكون و روشن اين كه كدام يك از تعابير 
استراتيزى ، نتايج و ياليسى ها به صورت منطقى

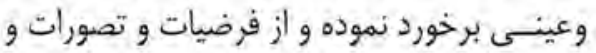
كلى كويـى كه نميتوان نتايــج منطقى را انتظار داشت ما را دور نكريميدارد . با نظرداشت اهميت اين مسأله است كه دربحث

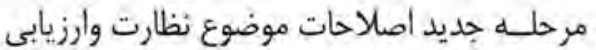

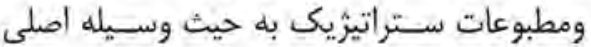

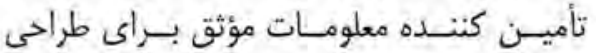

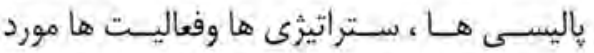

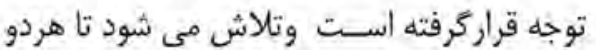

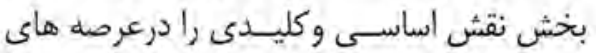

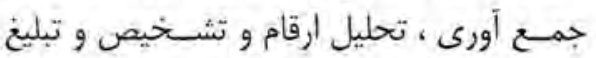

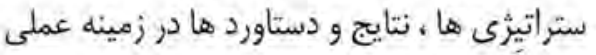
شـدن اصلاحات به حيث اداره هــاى تأثير كذار

أنجام دهند.

ظرفيت سازى در دو استقامت جز برنامه هاى

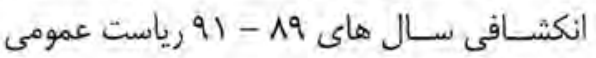

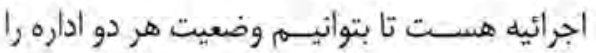
ازوضعيت اجرائيوى به اسـتقامت رهبرى كنتله

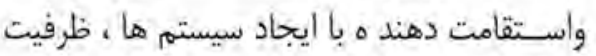
هـاى كادرى وادارى وصلاحيت تحليل وتهقيق

توسعd دهيم.

الصاح ادارة عامه به صورت كل در موارد سيستم

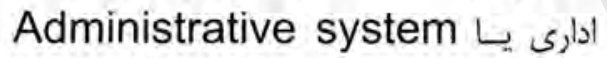
وخدمات ملكى يا Civil Service وخدمات عامه Public Service تطبيق مى شـود : درحاليكه سيسـتم ادارى مجموع راهكار هائ مانى

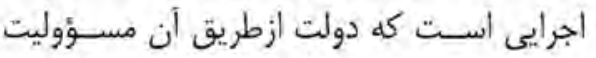

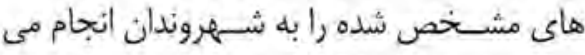

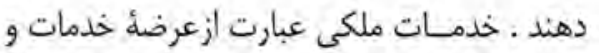

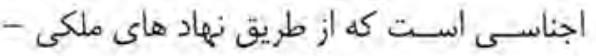

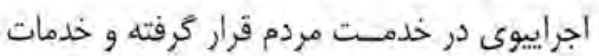
عامه عبارت از خدماتى است كه از طرف نهادهاي

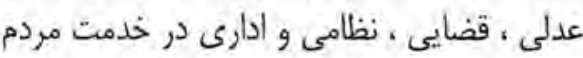
قرارداده مى شود .
حوزه ولايت وولسـوالى برنامه معلوماتى ترتيب

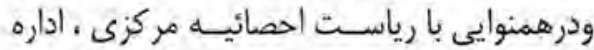

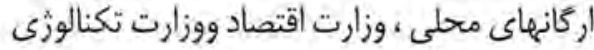

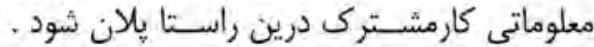
برنامه معلوماتى بايد به شـكل معيارى كه حاوى

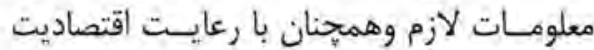

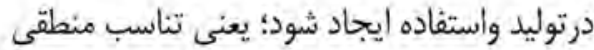

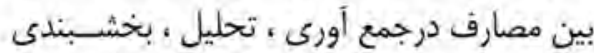

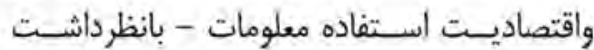
ظرفيت وامكانات- رعايت كردد . كميسـيون اصلاحات أدارى ازطريق رياست مطبوعات واطالاعات عامه ودرتفاهم با ريأست اصتات

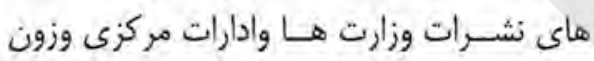

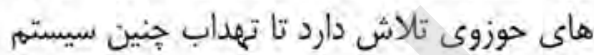

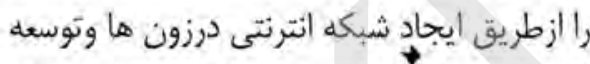

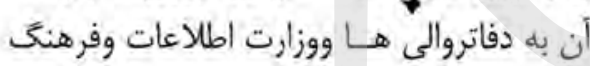

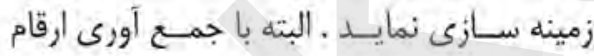

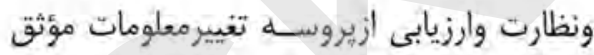
تربراى طرح باليسى هائ اصلاحسى هى تواند

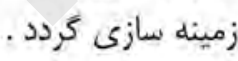

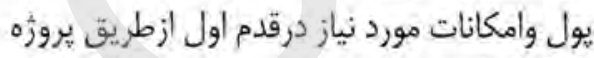
ACSS

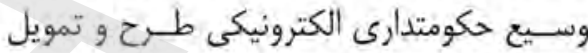
شود تا اساس حكومتدارى خوب كه درأن متكى لـي با ارقام واسـناد وشناخت واقعى مشكلات موجود بإليسى ها وستر اتيثى اصلاحى طرح وعملى شده

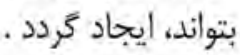
ضرورت است بيوند منطقسى بين ارتباطات ستر اتيزيك ونظارت وارزيابى برقرارشَّود تا درابتدا

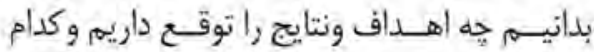
ستراتيزى يا فعاليت ها بايد انجام شود ومعلومات

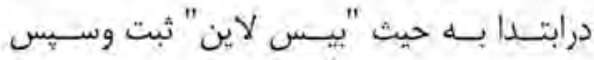
درفاصله زمانى مجدداً اندازه كيرى شود تا بدانيم

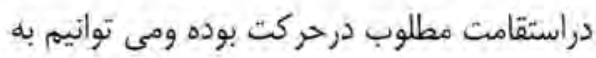

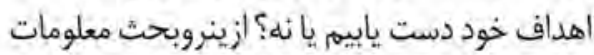
و ارقـام و اعداد مؤثق اصلاحات ادارى را همواره

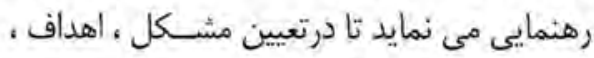

ائر در نظر داشته باشيهم ، براي اينكه بتوان عوايد

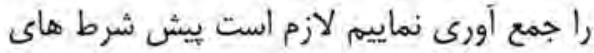

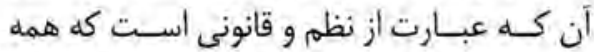
شـهروندان در اطمينان خاطر بتوائند از امكانات زنده گى مذنى همسـان برخوردار بوده و عدالت

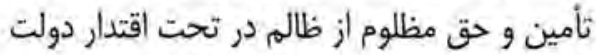
كرفته شـــه مى تواند، موجود باشد؛ يعنى امنيت

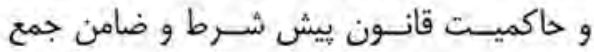

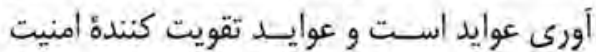
وحاكميت قانون و انكشــاف با سه عنصرامنيت ،

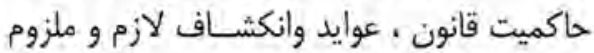

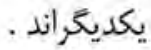

ازينرو بايد بـالان معلومات محلى طرح وترتيب

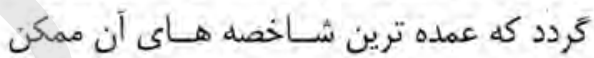

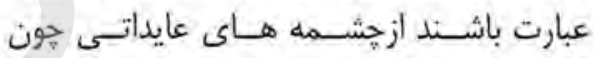
مساحت زمين ( از جمله زمين مزروع به تفكيك هاريك

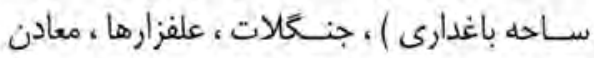

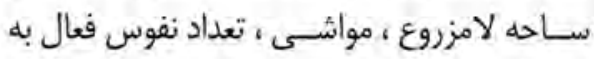

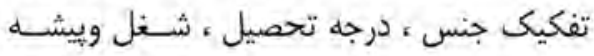

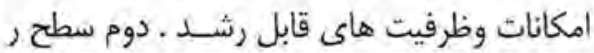

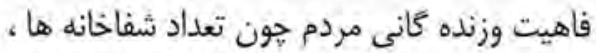

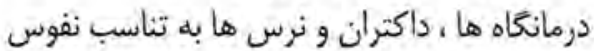

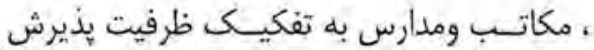

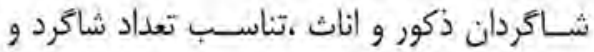

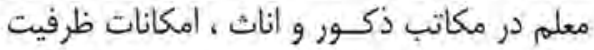
هاى رشد و ميزان مورد نيازسرمايه كذارى حهون بنــد أبيارى ، بند برق ، سـرك هــاى حلقوى و

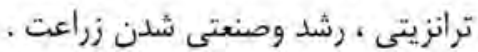

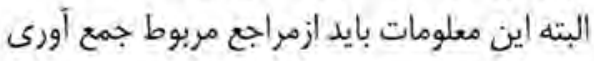

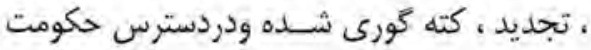

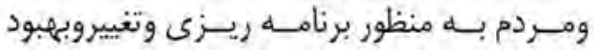

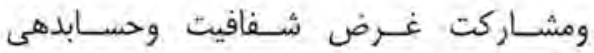
وحسابخيرى قراركيرد .

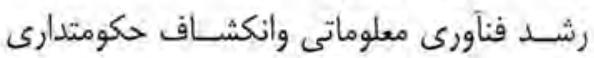

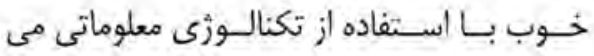

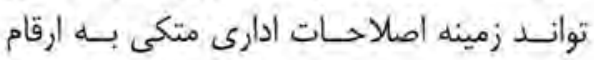
مؤثق را ميسرسازد؛ ازينرو ضروراست تا درسطح 


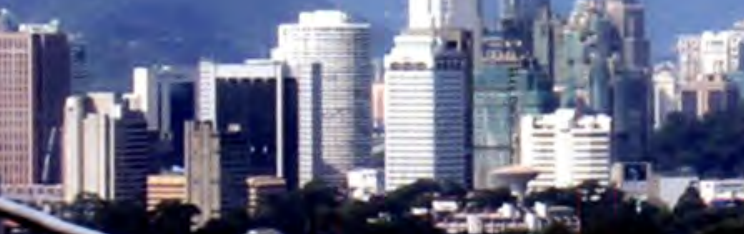

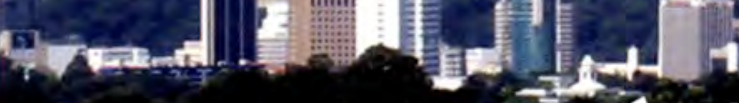
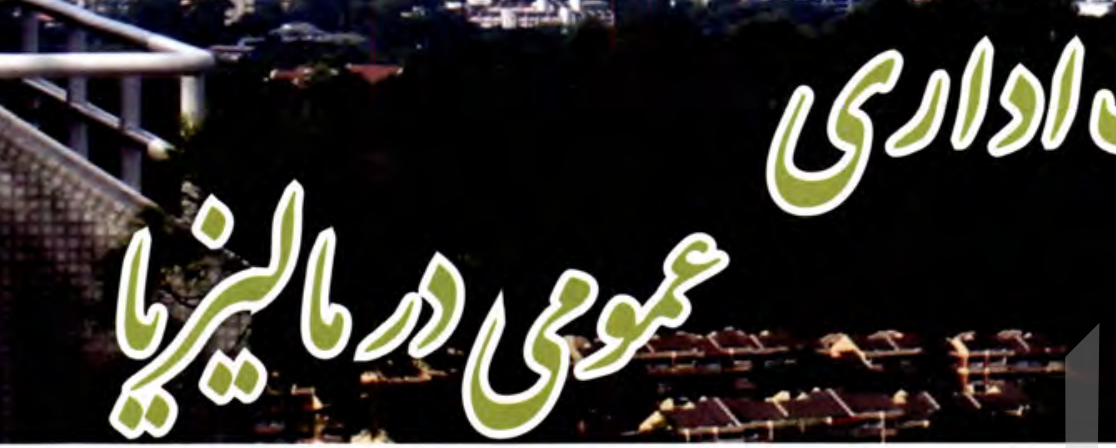

c)

جهت فراهم سازى و تسـهيل هر حه بهتر

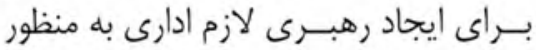
تسريع توسعه عرصه هاى ملكى.

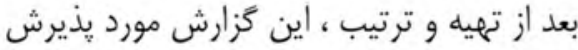

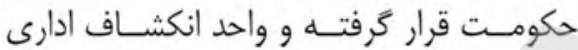
تأسـيس شد و اين نهاد در نوامبر سال وعال 198 به

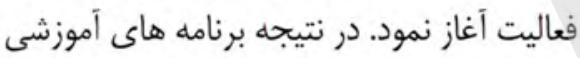

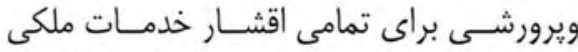

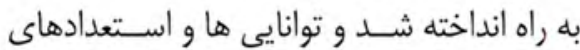
مسلكى كارمندان ادارى تقويت يافت. در جريان سـال هـاى •19 19 در حاليكه برنامه

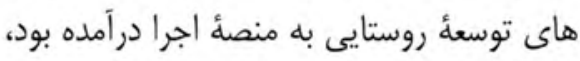
اين فرايند باعث ايجاد مشكلات فراوانى فرا راه

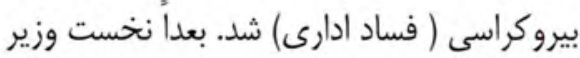

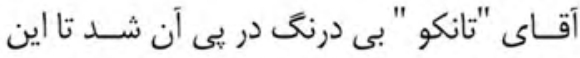

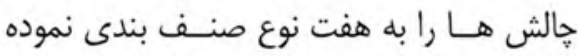

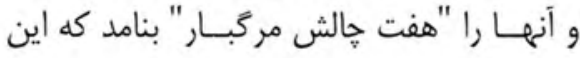
حالش ها در زير آمده اند: الدان

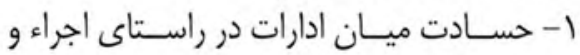
تطبيـق روزانــة امــور دولتـى و روش هاى
باشــد، تأكيدمى نمــود. بر عــاووة اين نهاد

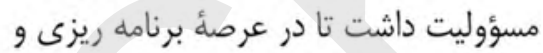
تطبيق فعاليت هاى اصلاحى ادارات، رياست

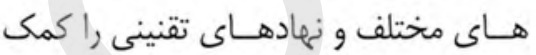
نموده و ممد واقع كردد.

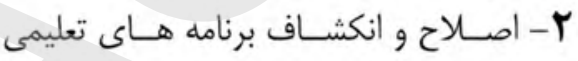
و تربيتـى حكومتـى بـــراى تمامى اقشــار

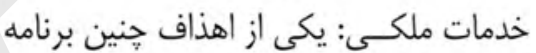

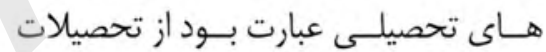

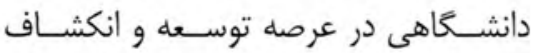
ادارى در دانشعاه "مالايا" كه در يهلوى آن آن فراهم سـازى زمينه تحصيلات دانشگاهى داري

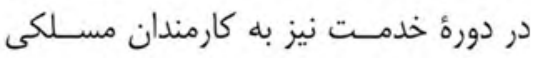
ييشــنهاد شــده بود. در نهايت فيصله بر آن

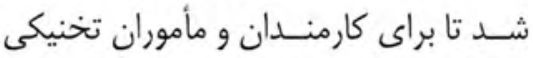
و ادارى تســيلات هر خه بيشـتر و لازم جهت راه اندازى روند آموزشى داخل خدمت هين و براى مأموران بلند رتبه و با تجربه سمينار هاى دوره يى راه اندازى كردد.

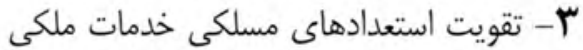

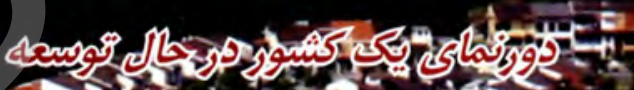

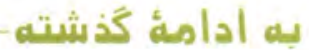

يشينهاد براى عملكرد دولت جهت ياره نمودن اصلاحات ادارى:

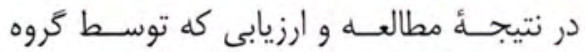

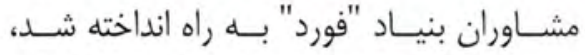
ي يشنهادى جهت راه اندازى اصلاحات در ادارات

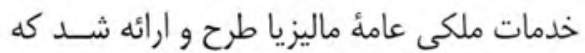

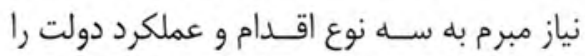
نشان مى داد: 1 - تشــكيل و ســاختار واحد ادارى و انكشافى در دفتر صدارت عظمى با گماشــن تحليل

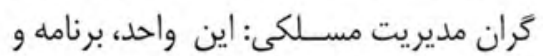

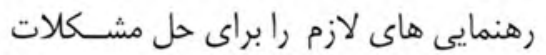

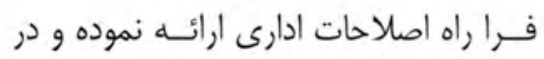
ضمن برداشــن تمركزبيشـتر بر دســـاه

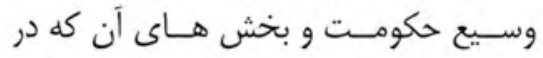

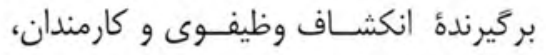
ارزيابى و وييخيرى هزينه ها و مسايل بودجه

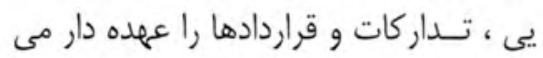




\section{روند تغيير در ادارات}

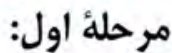

زمانى كه روش عملياتى تمركز بيشـتر خود را بر إن

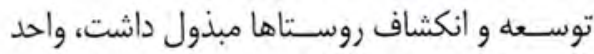

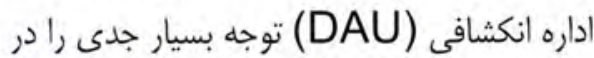

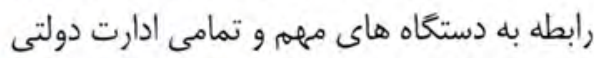
معطوف ساخت. بعد از فعاليت جندين ساله، واحد اداره انكشافى با ساختار اصلى و كاركردهاى خوالى خود

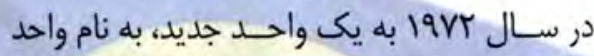
هماهنكى اجراآت و انكشاف ادارى (ICDAU)

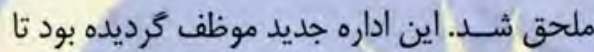

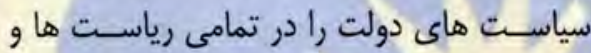

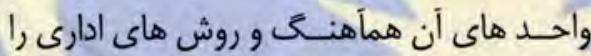
با وجـودى كه نقش و قيموميت واحد انكشـاف

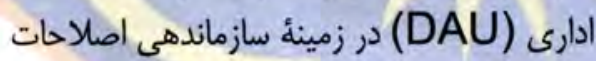

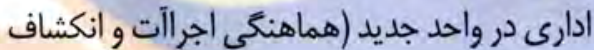

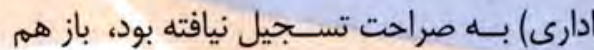

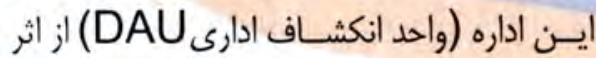
ظهور نيازها و كارهاى فورى كه باعث تســريع

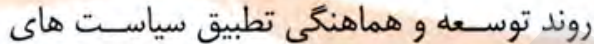

انكثافى دولت مى گرديد، رو به زوال گراييد.

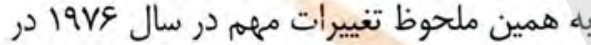
روش عملياتى ايجاد شد و به دنبال اين تغييرات بخش ادارة انكشـاف واحد هماهنكى اجراآت و ولني انكشـاف ادارى (ICDAU) به نهاد ملى ادارئ عامه منتقل يافت كه هدف اين نهاد جديد توسعه ظرفيت بــراى تفتيش مديريست و وارائه خدمات مشـورتى مديريت به شـركت هاى عامئ عامه جهت

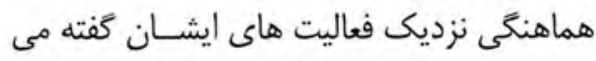

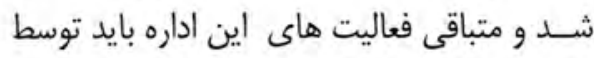
واحد همأهنكى اجرآت صورت ميكرفت.

\section{ادامه دارد}

مترجم: سميع الله سميع
ساز ممد واقع شد، مخصوصا دربخش اصلاح امور در سطح ولســوالى ها عملا در خور اهميت بود؛ طورى كه در يروزه هاى كوخى روستاه

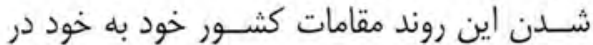
قيـــد اين روش كير افتادند، كميته هاى محلى در درات زمينه كارهاى سيرده شده مسؤول و در عين حال مورد نظارت جدى و مستقيم قرار مى كرفتند و باريا تطبيق اين روش فرهنگ جوابكويى و حسابدهى مسـؤولان دولتى نيز ترويج يافت. اين روش در

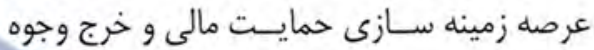

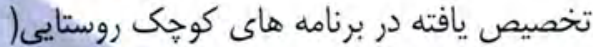

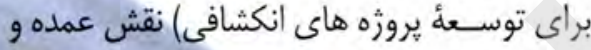
حياتى را داشت.

اين روش، بستر كسترده و كرم رادر جهت ايجاد روحيئ قوى كروهى و حس همكارى واحد ميان

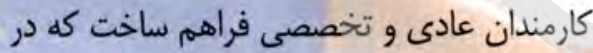

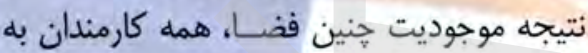

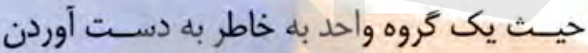
يك هدف خاص و والا، كه توسعه و انكشـاف روستاها بود، در يهلوى هم ايفاى وظيفه نمودند. اين روش هم جنان روابط ميان كارمندان خدمات

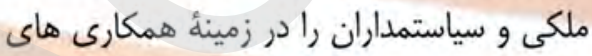
نزديك و ازدياد درك بيشتر از نقش بخش هان هاى مختلف در انكشـاف دهات به وجود آورد. به اين اساس مغايرت و تعارضى كه در ميان بيروكراتها

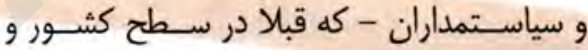
محلات بروز كرده بود- تقليل يافت. بايد كفت كه در جهـت مؤفقيت و يبيروزى قابل ملاحظة روش عملياتى جندين عوامل مهمه، كارا

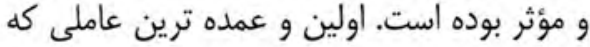
دراين راسـتا اهميت به سـز ايى را دارا بود، همانا

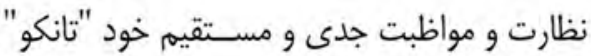

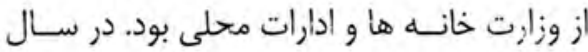

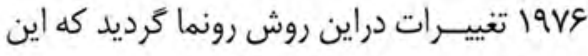

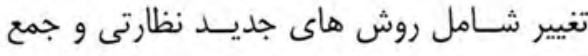

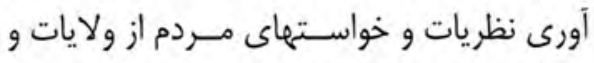
مناطق كم انكشاف يافته بود.
متنازع مابين رياست ها.

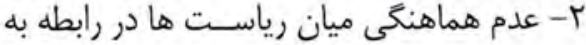
كارهايى كه در روستاها انجام مى يافت مان. r- عدم همكارى كامل ميان كارمندان ساحوى به علت نبود درك درست از وظايف و كاركرد هاى يك ديكر.

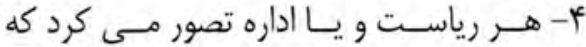
كارهــاى ايشـان از اهميت فــوق العاده يى

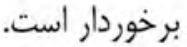

ه- عـــدم موجوديـت برنامه درســت و منظم در

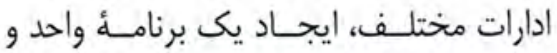
بزرى به ســـح روسـتاها را بــا حالش روبرو

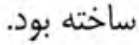

9- در كل نبــود برنامة عمومى در تمام سـطوح جهت توسعه و انكشاف عمومى در روستاها. V- عدم نظـارت جدى از جانب مقامات بلندرتبه دولتى تا از ييشرفت لازم كارهايى كه در دهات إنات

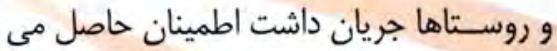
شد كه اين كارها رضايت بخش استند يا نه.

\section{روش هاى عملياتى ادار ه:} ايـن هفت حالـش مركبــار در راسـتاى فرايند اصلاحسـات ادارى دولـت، تنكناهايى را يديدآورد

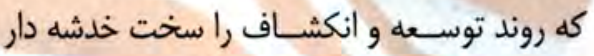
نموده و آنرا با كندى مواجه سيـاخته بود؛ اما لازم إندا بود تا اصلاحات ادارى خدمات ملكى بايد در همه

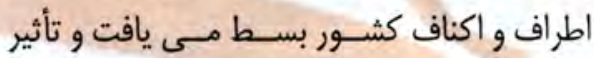
بسا مثبت در عرصة انكشاف روستاها مى داشت

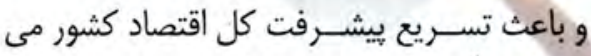

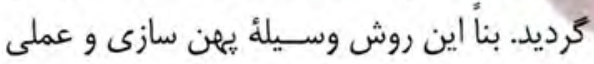
سازى انكشـاف در روستاها دانسته شدكه شامل

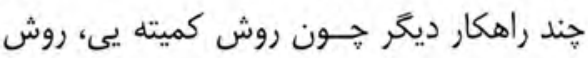

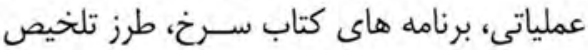

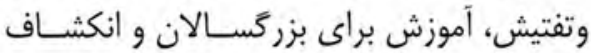
اجتماعى بود.

روش عملياتى يك راهكار مؤفق بود كه در جهت بعبود ارتباطات و هماهنگ مئى ميان نهادهاى برنامه 

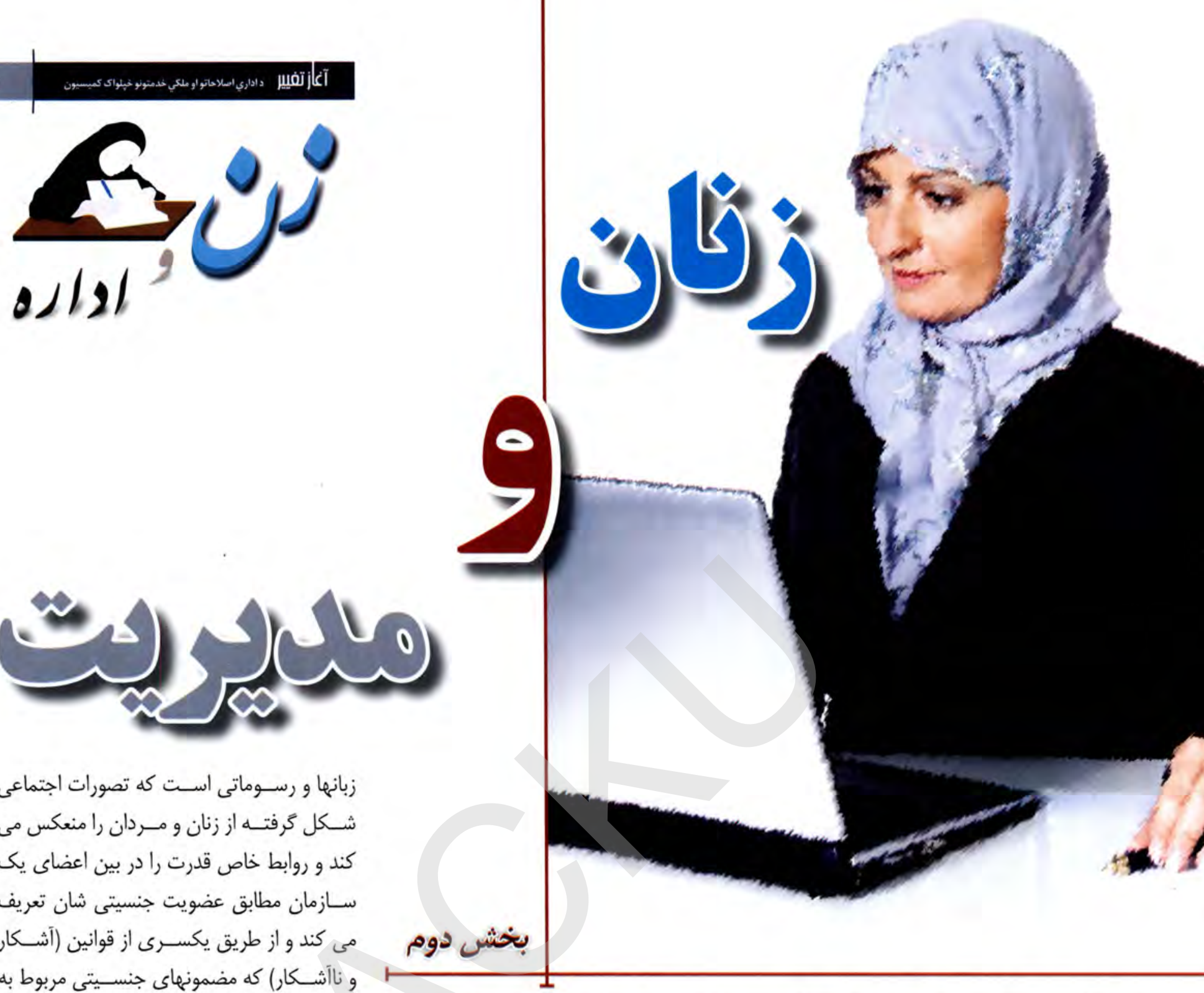

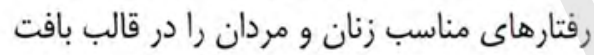

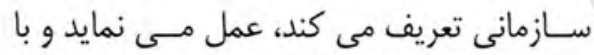

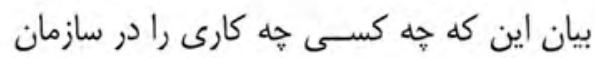

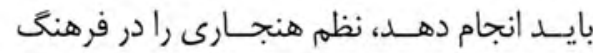

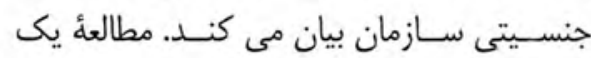

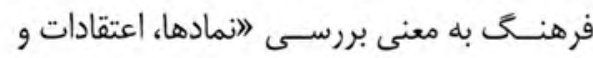

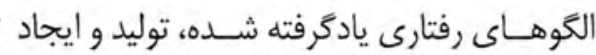

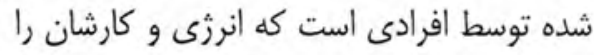

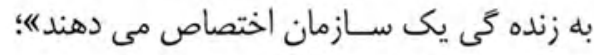

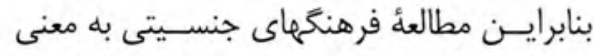

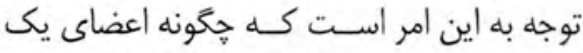
سازمان، نمادها، عقايد والكوهاى رفتارى مربوط إنه

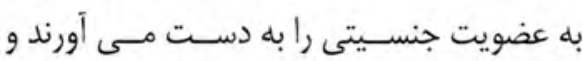
سيس توليد و بازسازى مى كنتد.

بــه كَفتهُ "هافسـتد" در برخى از جوامع و دارايـى ها مى باشــند. در اين جوامع مسـأله

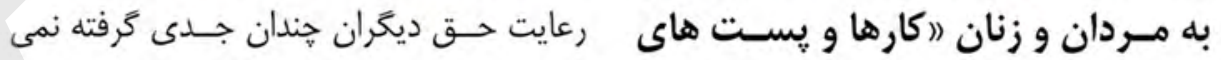

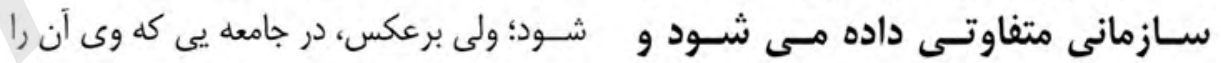

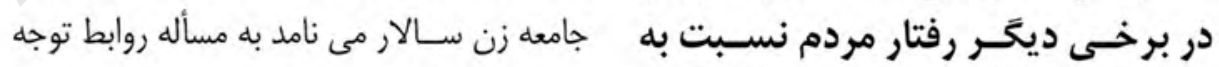

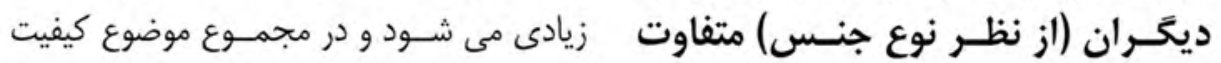

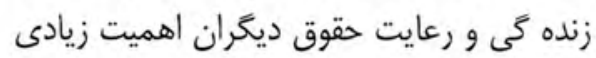

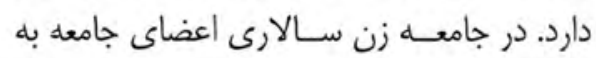

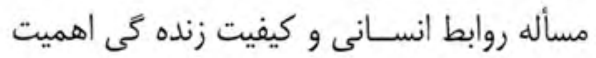

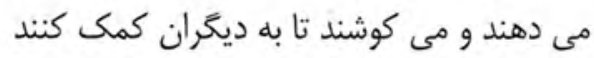

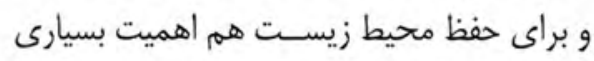

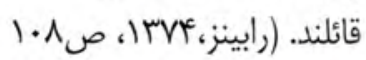
است). اين محقق مدعى اسـت كه در بعضى از جوامع

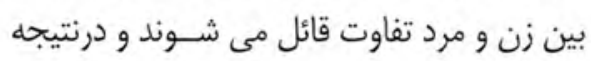

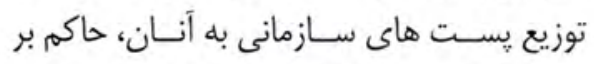
سازمان هسـتند و زنان بيشتر كارهاى خدماتى سانى

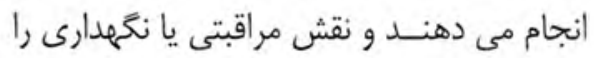

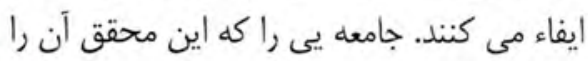

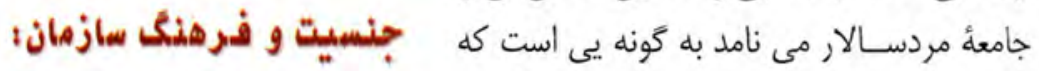
مردها حق ابراز وجود دارند و صاحب يول، اموال فرهنى سازمانى متشكل از ارزش هار ها، هنجارها، 
أنها كار مى كنتد تعريف مى كنتد و مجموعه بيى از تعاملات تقريباً سلسله مراتبى مبتنى برتقسيهم كار جنسيتى و انتظارات جنسيثى را در بردارند. در مجموع جنين به نظر مى رســـ كه زنان بيش

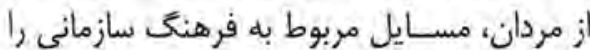
عامل عقب مانده گیى خود مي دانتد. أنها معتقدند

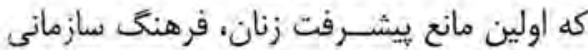
است. زنان مدعى اند كه برخلاف أدعاى مديران مسرد، در ورود به جرمكه مديريت امكان و فرصت مسـاوى وجود ندارد و موانع زنان بيش از مردان

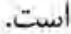

براسـاس اين ديدكاه، زنان از خود نقشى ندارند؛ بلكه موانع نامرنى جلــو ارتقاى أنها را مى كي كيرد.

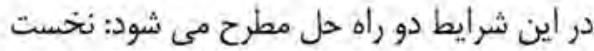

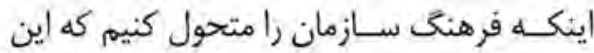
كار مستلزم برخورد فعال و منظمه است. "روزنريه مى كويد : لافرهنك سازمان بايد ثغيير كند. افر اد ماد

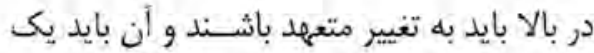

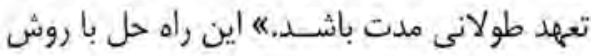

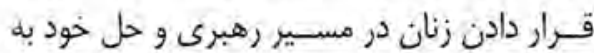

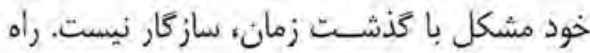

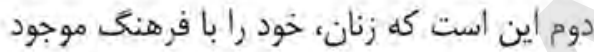
سازگًار كتند. اين همان شيوه يى است كه بيشتر

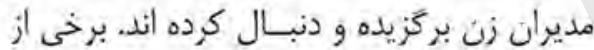
زنان مؤفق با يِيشسى كرفتن از مردان، راه خود را

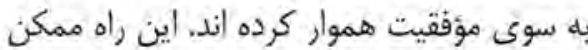

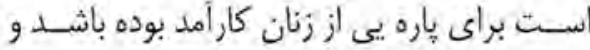

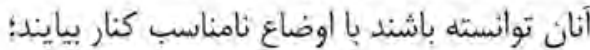
اما براى زنان باهوش نسل أَينده كه آرزوكى مقام

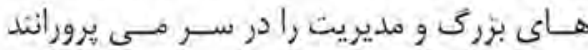

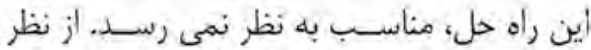
كارشَناسان مختلف، سازمان ها وقتى به حله حاكثر

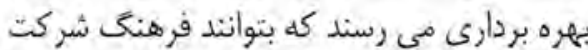

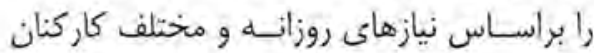

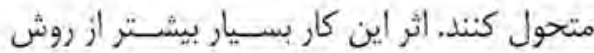
كنار آمدن زنان با فرهنى سازمان است. (زمانى

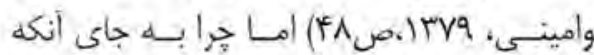

دامنه كاربرد اين قوانين ظاهرا جنسـيتى نيست؛ زيرا بــراى زنان و مردان به طور برابر به كار مى جى

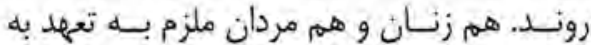
سازمان مى باشــند مثل ساعات طولانى كار كه

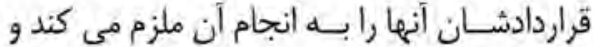

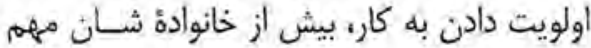

\section{1-2سيتورالعمل ها: رفتار كردن مائند}

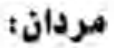

دومين گروه قوائين، مجموعه اي أز رفتارهايى را كه زنان براى دستيابى به مؤفقيت بايد انجام دهند ييشـنهاد مى كند. إين قوانين، تجويزى هستئد؛

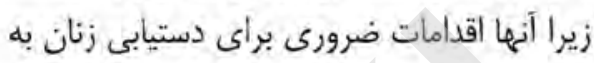
اهدافشان را مشخص مي كتند و مجموعه يى ازئ يشينهادها را كه در بي ايجاد تصويرى أز وظايف

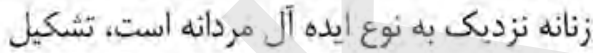

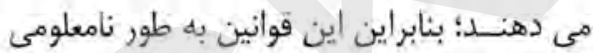

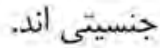

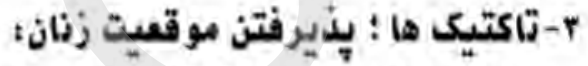
دسـتأ سوم قوانينى اســت كه تاكتيك ها ناميده مى شـوند: اين ها نكرش ها و رفتارهائي هستند

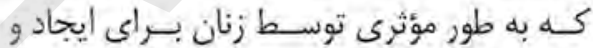
حمايت از موقعيت شَـان در سازمانها، وضع شَده اسث؛ بنابراين أنها نه حكم سازمانى هستند و نه

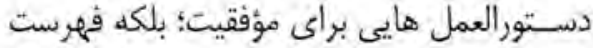

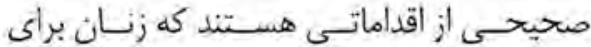

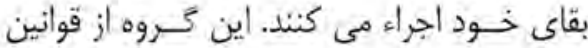
بـهـ زنان توصيه مى كتند كه به سـرعت به يكى شغل مبادرت نكتند و أز رقابت مستقيم بأ مردان اجتناب كنتسـد و روابط را بر مناسـبات برابر قرار.

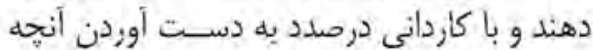
كه بهتر است باشنا. در بايان مى توان كفت كه فرهنگ هاي سازمانى

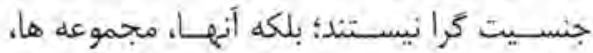
وظايف و رفتارهاى خاص مردان و زنانى را كهد در

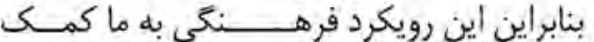

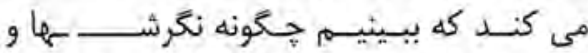
رفتارهـا درمجموعــه هــائى سـازمائى از طريق نمادهاى مختلف مثل زبان، ارزش ها، تصورات از جهان، هنجارها و رسوم، ساخته و به هم ييوسته شده يا تعيير و تضعيف يافته است.

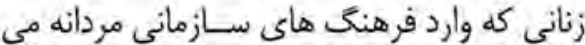
شوند با قوانين سـختى مواجه مى شوند كه إين

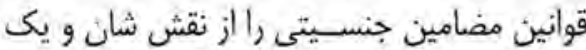

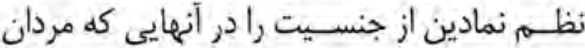

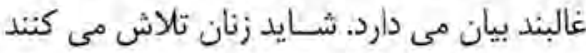

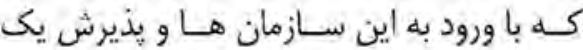
موقعيـت سـنتى مر دانه، نظمه جنسـيتئى نمادين ايجاد كنند. بسيارى از توضيحات مرسوم در مورد

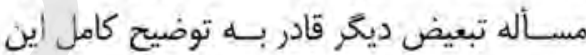
بريده نيست. مخصوصاً تئورى هاى اقتصادى در

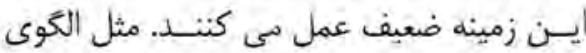
نئوكلاسيك - كه تبعيض را به عنوان محصول

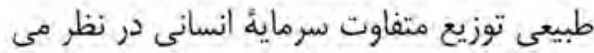

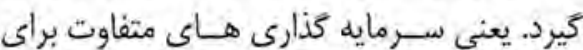

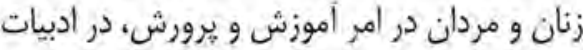
اسـتعاره هاى مختلفى وجود دارد كه زنانى راكه وارد مجموعه ها يا مشاغل مرد محور مى شُوند.

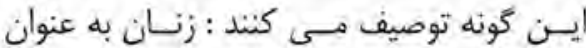
مهمانـان ناخوأنده يـا بيكانه و زونـان به عنوان ســبازان يا مسـافران. اينها برخـى ازئ تصورات

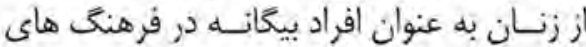

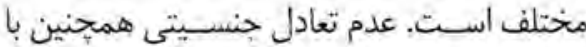
بِّيرش رسومى كه رنكَ تفاوت به خود مي كيرد

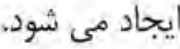

به طور كلى سـه دسـته از قوانين وجود

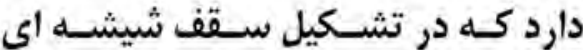
مؤثر است و ممكن است در هر سازمانى

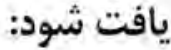
نخستين كروه قوانين كه ممكن اسـت شرايط

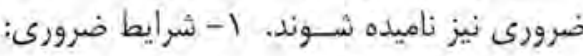
قوأنينـى برايى هر كس مورد احتر ام منى باثــند. 
$-5$

raya . killian the working women amale manager " $s$ viw american management association , inc , 1997

-V

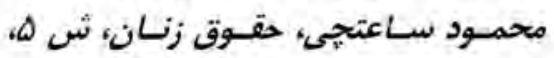

ITVY

1- مشبـاركت زنان دو جالش هـايى اجتماعى و

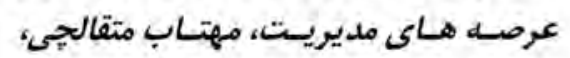

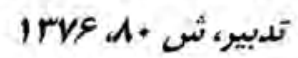
$-9$

sue led wirh and fiona colgan.

Women in organization 1998 Iondon

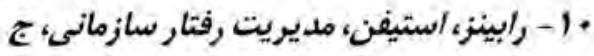

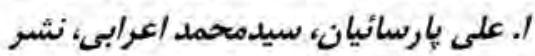

مؤسسه مطالعات و يثروشيهاى ITVF

recreating Silvia Gherardi and

BarBara poggio." Greating and Gender order in organizations" journal of world Business / 36 (3) /2001 245-256.

rا - فاصلسه بيسن زنسان و مسردان دركارهاحى

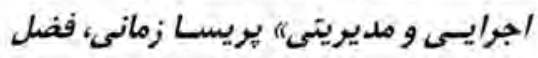

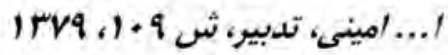

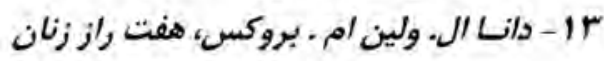

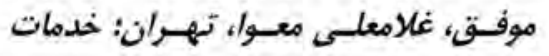

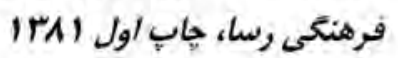

Mia Hultin - Ryszard Szulkin.

"Wages and unequal Access to

Organizational power."

Administrative Science Quarterly, (1999): 453-472

يايان
ديكر يررنغ تر باشــد. به اين معثى در سـازمان

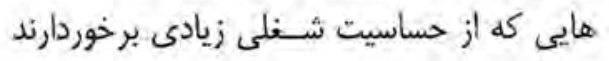

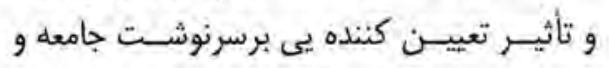

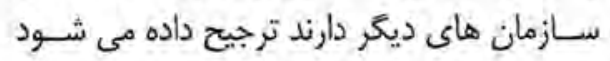

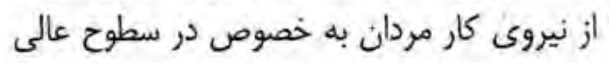
و يست هاي كليدى اسـتفاده شود. و اين همان

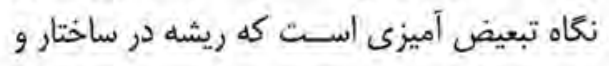
ماهيت سازمان دارد. با توجه به اهميت روزافزون مديريت منابع بشرى و نقش تعيين كنندها آن در

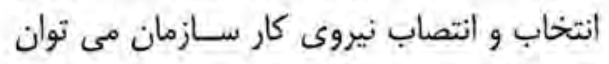
كفت كاركنان نيروى اسـتخدامى، بايستى اصل شايسته كزينى را سرلوحه برنامه هاى استخدئ

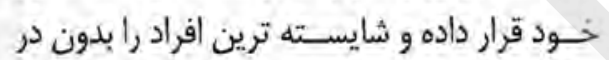
نظر كرفتن جنسيت أنها، بركزينتد. فربرست منابع: ا - زن و مديريـت" جميلـه كديسور، ييام زن، irk. r- ز زن، دانشـعاه،. فرداي بهتر. (مطالعات زئان 1)، مجموعسه مقالات و كزارثـهاى كنكره ز r- آمـوزث مديريست بـراع زنـان" بإئوليـن

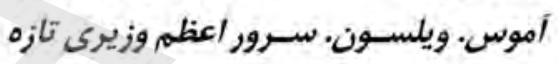

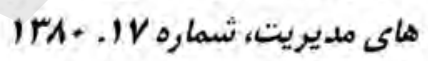
$-\boldsymbol{f}$

Wentling-Rose-Mary. "Astudy of the career development and Aspirations of woman in Middle management "Human - Resource - development - Quarterly 7(3).

Fall 1996 , p 253-70

johnson. Gall dean. Has management gone soft? Yes and it works; women in5 business, may/jun 97 . vol. 49 , p32. gp. $2 c$
مردان اين شرايط را تغيير دهندزنان بايدخود را با سياست هاى سازمانى تطبيق دهند؟

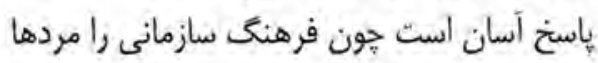

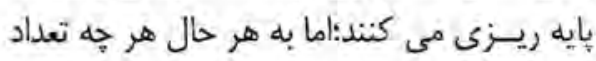

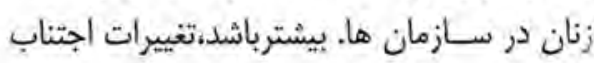

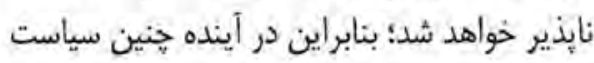

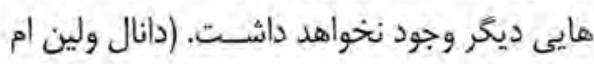

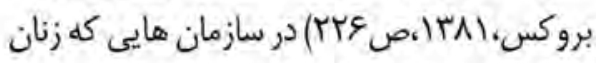

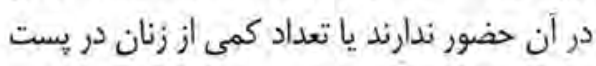
هاى صاحب قدرت حضور دارند جنسـيت ممكن

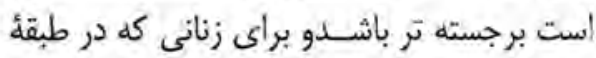
هايين تر سازمانى قرار دارند نتايج منفى دارد.. در جنين سازمان هايى در حاليكه مردان منابع رادر

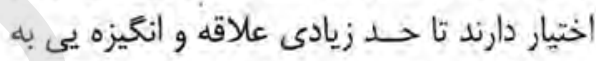
خنثى كردن رفتار جنس مدار خود ندارند. ״ايلى"

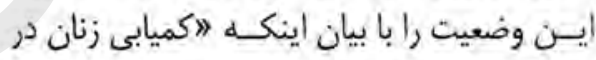

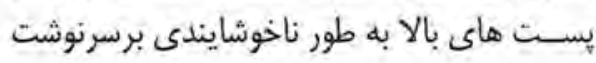

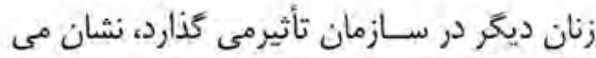
دهد. همجنين جندين محقق ديخر براين انديشه

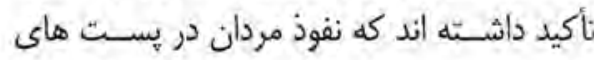

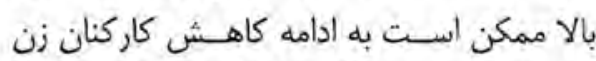
كـك كنـد. Hultin\&Szulkin), ( $(\Delta \Lambda-F \Delta V$ "بارون 1" ملعى اسـت كه كليشه هانى جنسيتى كه ريشه در ترتيبات و دستور العمل هاى سازمانى كلى هائل

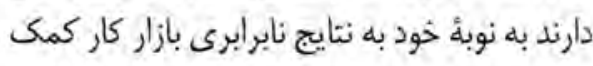

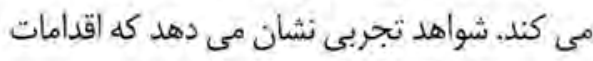

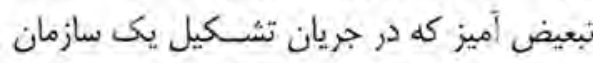

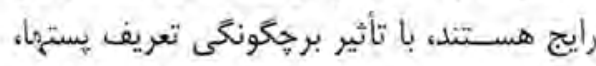

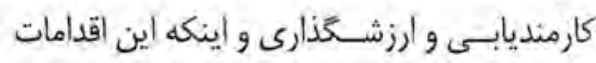
ذر ساختار سازمان كنجانده شده و رسميت يافته،

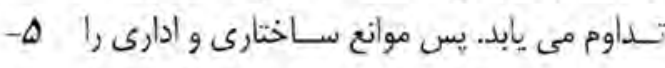

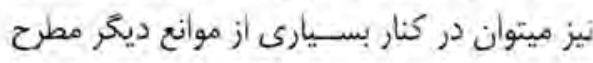
كرد. به عبارتى سـاختار و تشـكيلات و و ماهيت

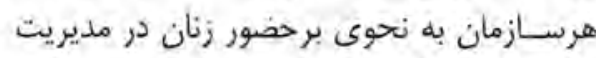

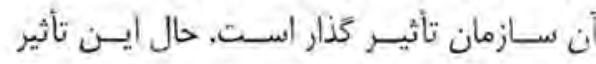
ممكن أست در سازمانى كمرنك تر و در سازمان 


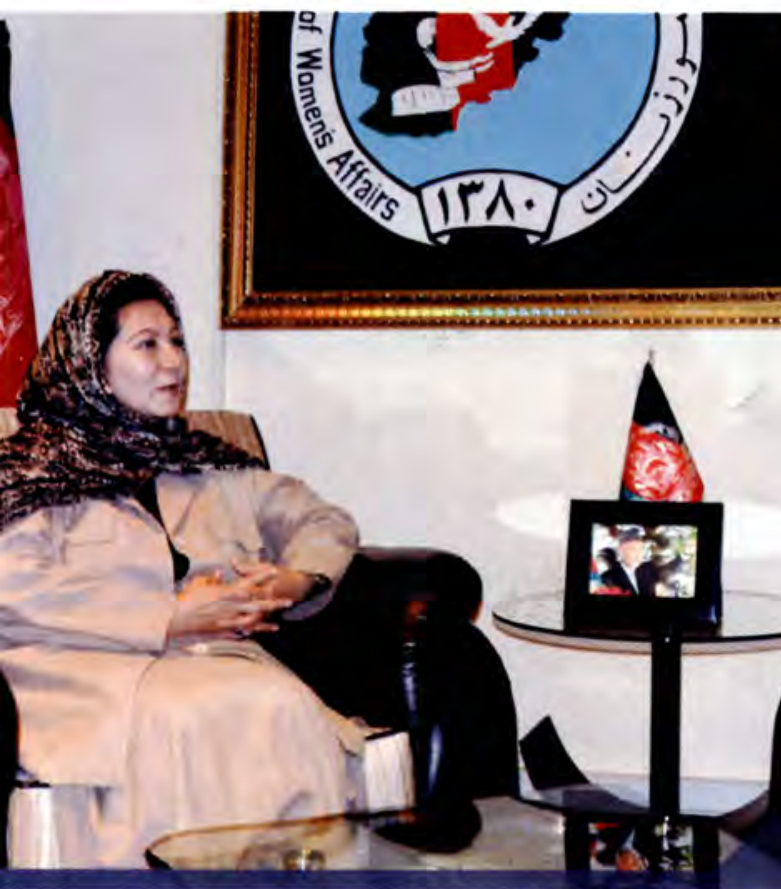

برنامه ها درســوح مختلف مى شـود

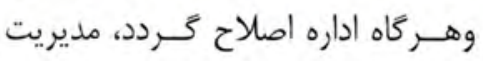
بهبود حاصل كرده كار از مسير هدفمند خود انحراف نمى كند.

يرسش:-از آغـاز تطبيـقا برنامـف اصلاحات כر اين وزارت .يه لهات تغييراتى در بهبود سيسـتم هـاع كارىا و عرضف فدمات

به وجود آمده است ؟

ياسخ :- طورى كه ميدانيد تشـكيل رياسـت

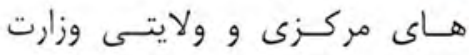

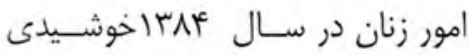

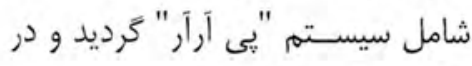

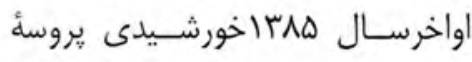
متذكره بــه طورمؤفقانه تطبيق كرديد وتمام كارمندان رياست هاى مركزى و وله ولايتى مشمول برنامه يى آرآرشدند.

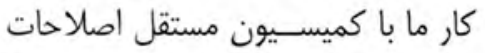
ادارى خوب ييش ميرود، كسـى بربنياد

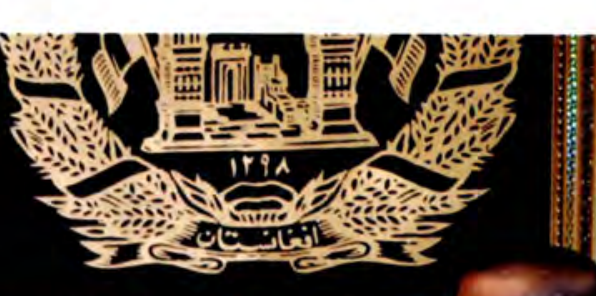

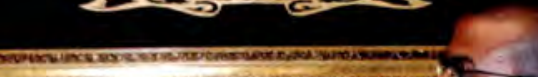
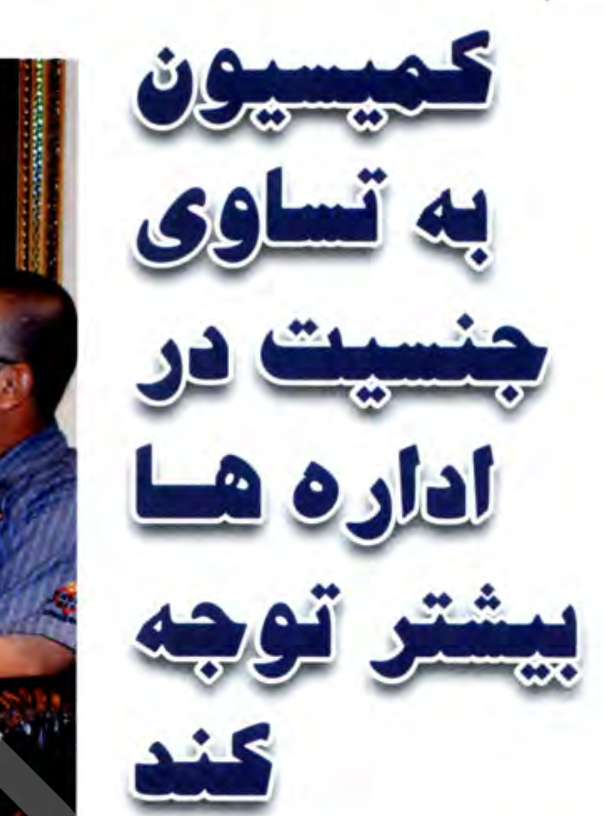

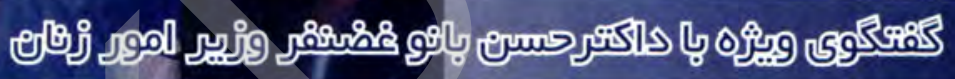

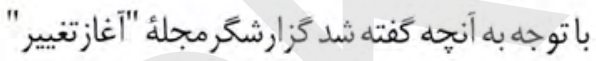

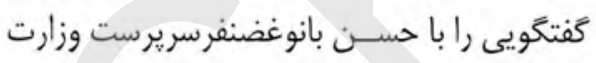
امورزنان انجام داده كه با هم مى خوانيه:
\end{abstract}

تصميم كيرى هاى سياسى است.

يرسشا:-ديدكاه تان درمورداصلاحات

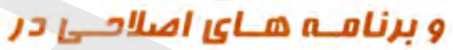
اداره عامه كشور ميست ياسخ : - درقدم نخست ازاعضاى رهبرى و تمام همكاران كميسيون مستقل اصلاحات ادارى اظهارسياس مى كنم به خاطر اين

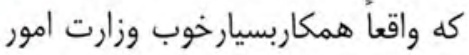

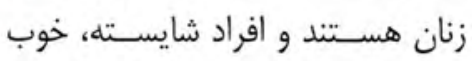

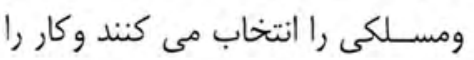

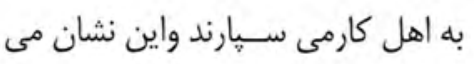
دهد كه كميسـيون مستقل اصلاحات ادارى به طور بسياردقيق كارمى كند.

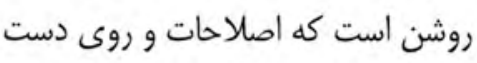
كرفتـن برنامه هاى اصلاحسى درادارئ عامه سـبب اسـتحكام مديرت تطبيق
بازسازى و يِشرفت افغانستان مستلزم سهمخيرى همه جانبئ زنان درعرصه هاى سياسى، اجتماعى،

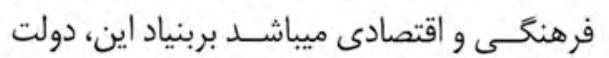
اهداف و تعهدات مشخص را به منظور يِيشرفت و اشـتراك زنان درعرصه هاى متذكره

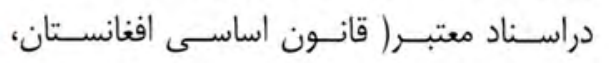
سـتراتيزى انكشاف ملى، قانون كاركنان خدمات

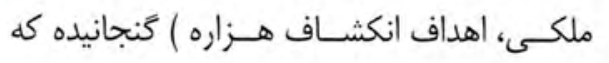

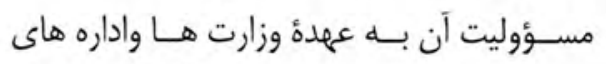

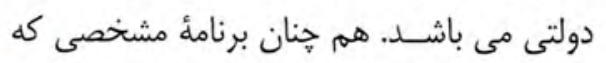

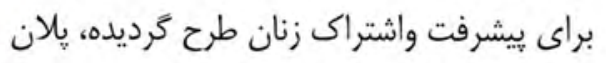
عملى ملى كارى زنان است.

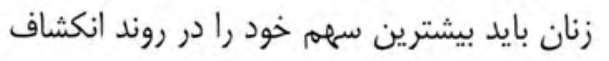
افغانستان داشته باشــند، با وجودى كه در زمينه توجه به نقش زنان ازجانب دولت برداشـته شده

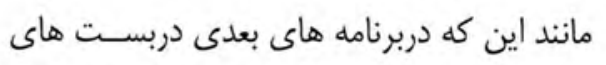

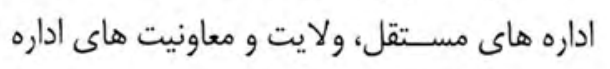

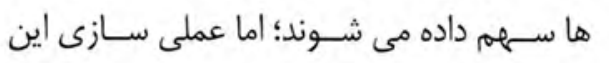

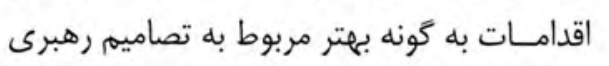

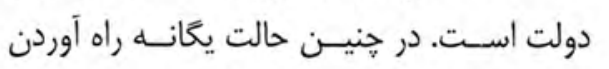
تغييـرات بنيادى افزايش تعداد زنان در ســوح دون 
هسـتند، تا حه اندازه دررشتهُ تحصيلى

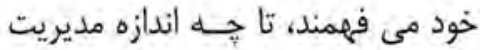

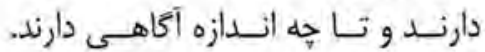
البتــه اين مســايل درجريـان مصاحبه برمهـلا ميشـود و آرزو دارم كه درجينين حالـت روابط درنظر كَرفته نشــود، بايد تخصص، مديريت ودانايى يك شخص بيـش ازييش درنظر كرفته شــود واين مدين

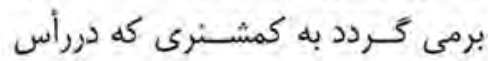
مصاحبه قــراردارد. بلاخره مســؤولان كميســيون مسـتقل اصلاحات ادارى مصى هسـتند كه مى توانند درأخرين تحليل يكى شَـــص متخصص، متعهد ،دلسوز

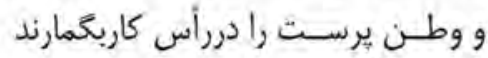
كـهـه واقعاً به وطن خدمت كند ودر آينده

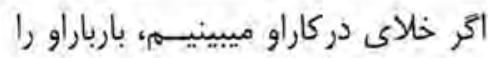

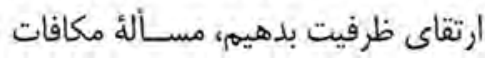

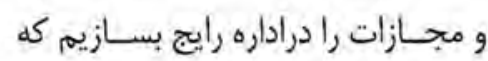

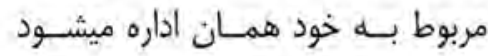

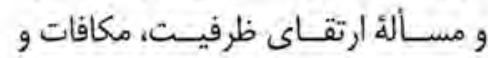
مجازات دسـت به هم داده ، مى توانند زمينه به وجود آوردن يكى ادارة سـالم ا همواربسـازند كه در نتيجئ انجام كار سالم, وفعاليت هاى مثمر ومؤثر، خواست

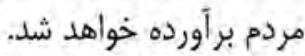

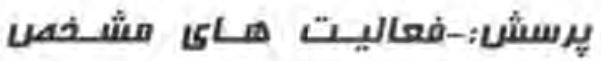

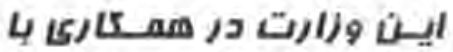
كميس_يونا در سـال روالً

\section{5 تصن}

إساخ :- عموماً به شكل روزمره فعاليت هايى را كه كميسيون مستقل اصلاحات ادارى با ما انجام ميدهــد، دراجراى كارهاى روزمره اصلاحات ادارى همكارنزديك مانى شـان هسـتيه: برعـالاوه يـك نكته
جذيد رتب ومعاش وان در برخى از اداره ها تطبيق گرديده ودر ديكر اداره ها در حال تطبيق مى باشــد، اين سيستم به

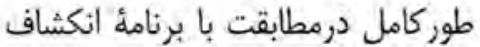
ملى افغانستان و نيازمندى هائ موجود اداره ها آماده كرديده كه بله طورقطعى هيى باعث ايجاد سـهولت ها براى مراجعين مى كَ دد و ازاين نغاه من به اين يروسه وبه نقش كميسيون مستقل اصلاحات أدارى نظرمثبت دارم. اما به شرط آنكه روزبه روزاين نقش بهترو بهترشده برود

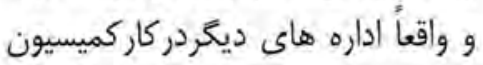
دخالت نكنتد وكميسـيون هم افرادى

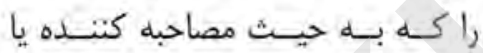

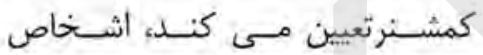
مسـلكىى، متخصص و بــا تحصيلات

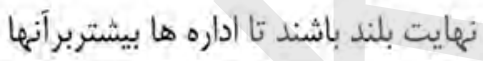

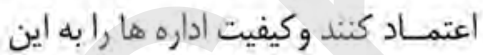
شكل بيش از ييش بهتر بسازند.

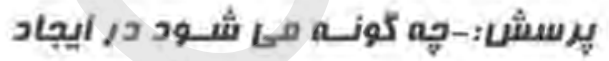
اכاره سـالم بـه /هدافها كه نياز قبرم مردم افغانستان

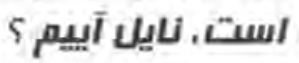

ياسخ:; - زمانى كه كميسيون مستقل اصلاحات

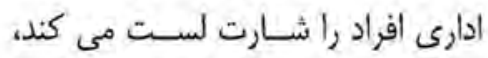
بأيد دقت بسيارخوب را به خرج دهند تا افرادى استخدام شوند كه واقعاً شايسته

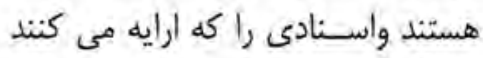
تقريباً •ه - -ع فيصد اسـتعداد شـان

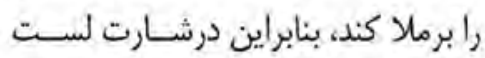
كسانى نيايند كه ضعيف هستند و اسناد براد دقيـق نذارنــــ اما وقتى كـهـ مصاحبه مى گيرنسـد، قدم هاى بعلى ســنجيده

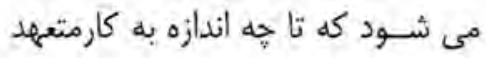

واسـطه و وســيله دروزارت امورزنسان

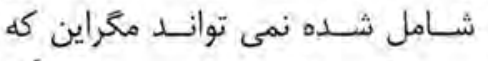

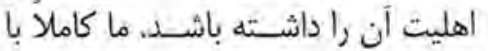

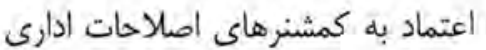

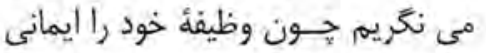
و وجدانسى ادا مى كنند و كسـانيكه از طريق رقابت آزاد مؤفق شــده اندة مى ونى توانيم ازآنها استفاده خوب نماييم.

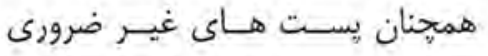
ومشابه كه سبب تناخل كارى همديخر مى كرديسلد، به همـ كارى متخصصان

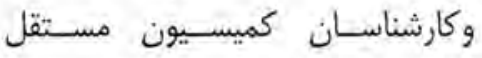
اصلاحــات ادارى ومســؤولان وزارت امور زنان حذف كرديد وطبق نيازمندى

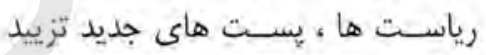

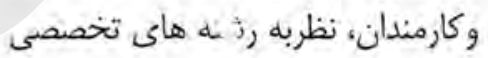
و تجارب كارى استخدام شد. هم خنان يك كارخوبى را كه كميسيون مستقل اصلاحات ادارى و خخدمات ملكى يلى دارد، اين اسـت كه وقتـ نوقتاً كاركنان وزارت ها را به انستيتوت خدمات ملكى

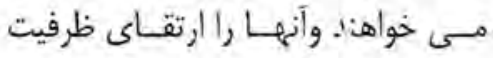

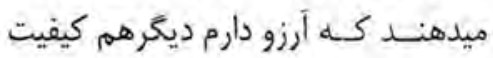
برنامه هاى ارتقاى ظرفيت بالا برود.

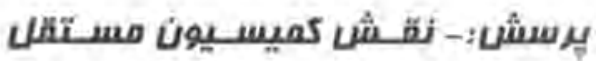

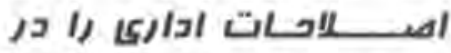
راسـتاعا ايجاد ادارة سـالم در كشور يكونه قى بينيد؟ קإسخخ:- نقـش كميسـيون مسـقل اصلاحات ادارى در ساختار تشكيلاتى اداره هاى دولتى فوق العاده مؤثر ومفيد است. حرا كده از أغاز بروسئ اصلاحات كه در كام نخست يياده نمودن سيستـم بـى آرآر بوده وبعداً راه اندازى وتطبيق يروســـ نئ. 
ملكى مهيا بسـازند تا فارغان ما نا اميد

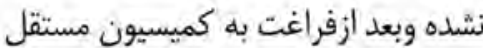
اصلاحسات ادارىى مراجعه نموده وهمين تجربئ كارى راكسب نمايند.

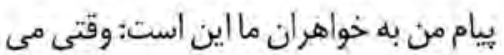
خواهند كاركنند، تحصيلات عالى داشته باشند و در يهلوى تحصبل كوشش كنند

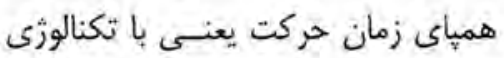
نوين و مديريت معاصر آشنايى يبدا كنند جون كشورما روبه انكشاف است و بلدون مهارت ها نمى ثوانيه زنان را اسـتشخدام

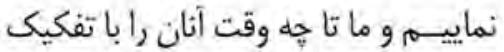
مثبـت جذب كنيـمه و تفكيك مثبت هم ازخود يك زمان معين دارد ( يكى سـال.

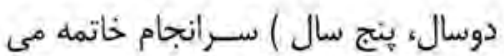
يابد. - ئ امــا از ايسن كه اين مهارت ها را كسبـب كنند ويا تحصيلات خود را به بائه اكمال برسـانتد مأيوس نشــوند حالا انستيتوت ها و يوهنتون زياد شــده وآنها مى توانتد به نحصيـلات خود ادامه بدهند و دريكى

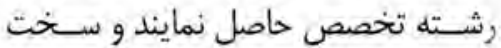

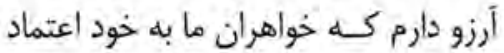
كثند كه أنها داراى أستعداد كافى هستند، صرفأ كمى تلاش بايـــ كرد جون بلدون

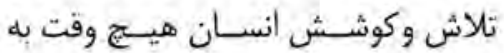
جايى نميرسد.

كقتكو: سيد فقير شيهروتد
ياسخ :- بلى كاركنـان وزارت امورزنان در امر تطبيق سيستم جديد رثب ومعاش كه كارن

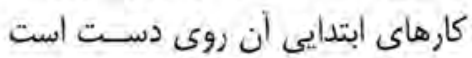

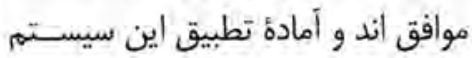

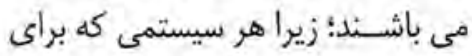
كاركن امتيازقايل شود وسهولت ايجاد كند نه تنهـا وزارت أمور زنسان؛ بلكه

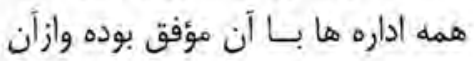
استقبال مى كنند.

يرسش:- حفورزنان درخدمات ملكيا درفيهدعا يايبـن قراردارد. بيام شــا به آن عده اززنان كم م- خواهن 2 כركدمات ملكـا

\section{קيست؟}

ياسخ: - مسن دوييـام دارم يكـى بـه آن عده اززنانى كه مى خواهند درخدمات ملكى دويى حضورييدا كنتد و يك ييام به كميسيون

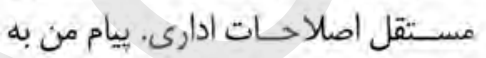

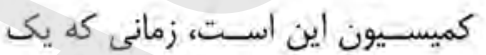

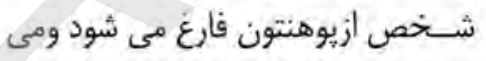
خواهد دريكى بست رقابت نمايد نسبت

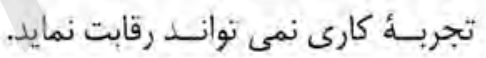

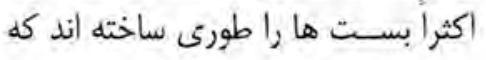
بدون تجربئ كارى أستخدام نمى شوند

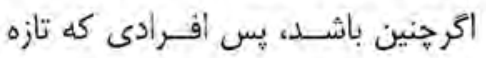

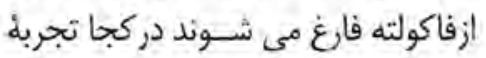
كارى كسب كنند.

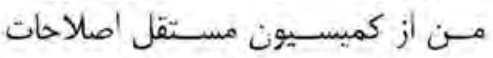

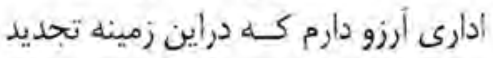
نظركتند ويا براى اخذ تجربئ كارى يكى

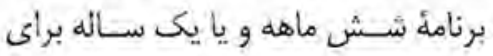
تمام فارغان يوهنتون ها كه درهربسال

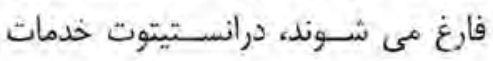

را مـى خواهــم ذكركنم كـهـ عبارت أزحسـاس ساختن كميســيون مستقل اصلاحسـات ادارى ازنكاه جندراســ؛ يعنى كميسـيون به تسـاوى جنسيت

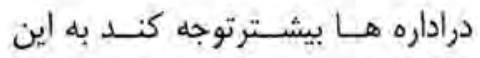
ارتباط يك مشاورجندر را در كميسيون

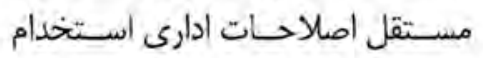
كرديـهم و آرزو دارم به همان شـكلى اصلى

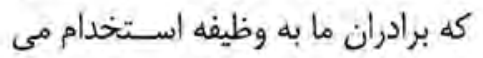
شـوند، خواهران ما نيزبيشتراستخدام شـوند؛ جون داوطلبـان كارو تحصيل

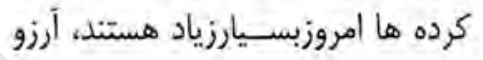
دارم كه كميسـيون مستقل اصلاحات

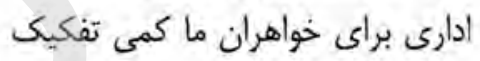
مثبت قايل شـود به منظوراين كه سه دهه جنى آنها را بسيار ضعيف ساخته و مانتــد برادران خود نتوانسـته اند به كورس ها مراجعه كنتد و نتوأنسـته أند ساحه وسيع آموزش را دردسترس خود داشـته باشند. لذا درابتدا براي دايمم نى ردئ بلكه موقتأ براى مدت سه الى ينج سال با تفكيك مثبت زنان را همكارى كنت مئد هرا كه زنان و دختران زياد جستجوكر

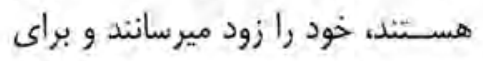
كرفتـن ارتقـاى ظرفيـت اســتعداد

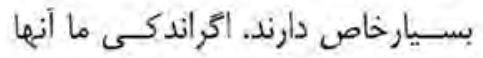

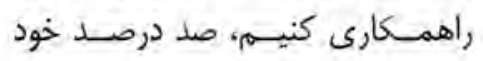
أ ميرسـانتن. به هميـن منظورمن أز كميسـيون مسـتقل الصلاحات ادارى آرزودارم جندر را فراموش نكند.

\section{يرسشا:-آيا كاركنان وزارت امورزنان} آماده الـد تاسيسـتم جديد رلب ومعاش دراين وزارث تهلبيقا شابود5 


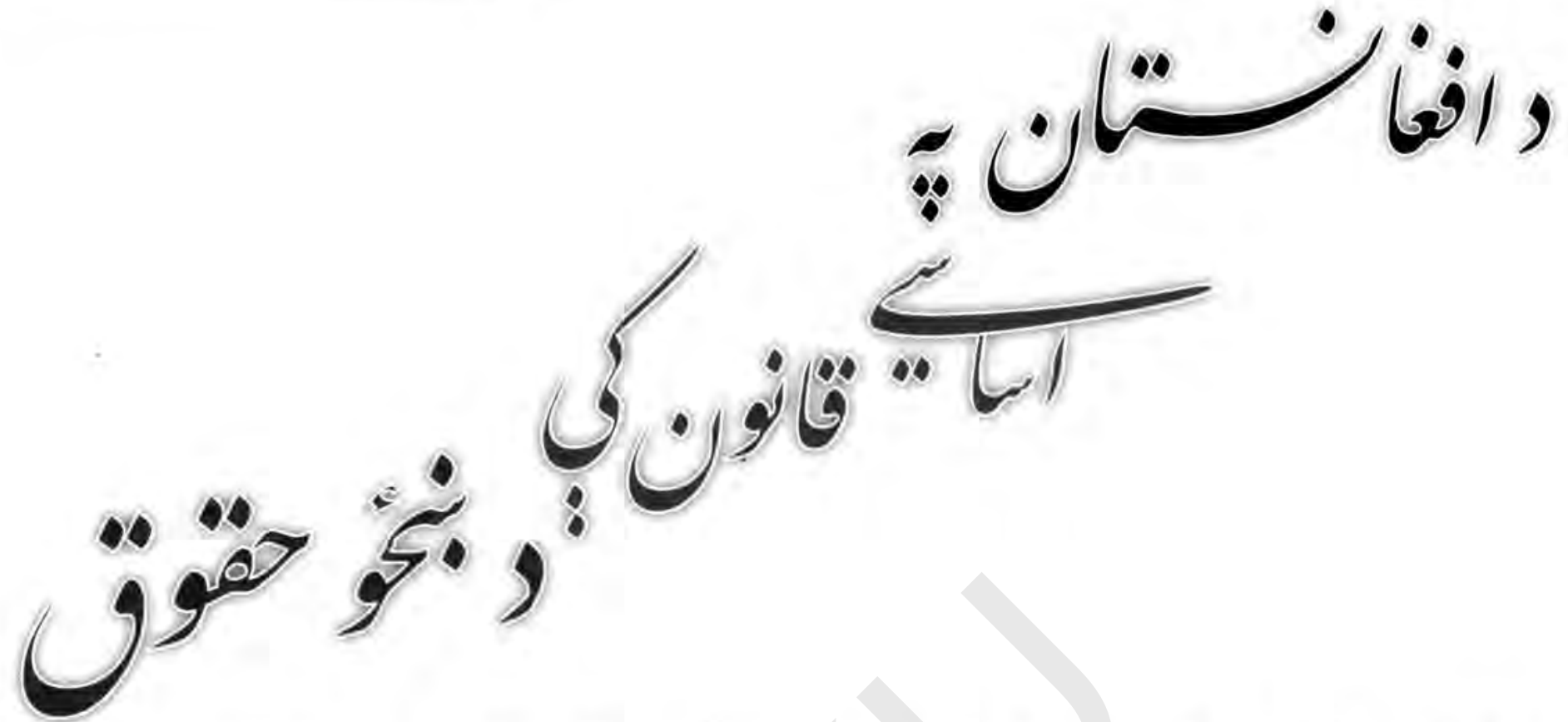

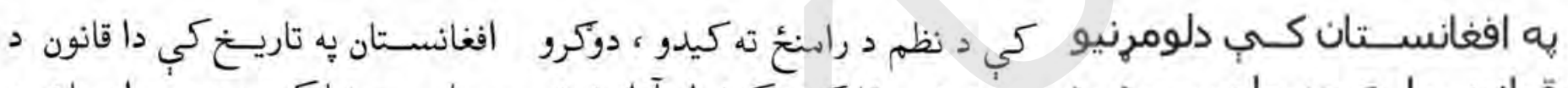

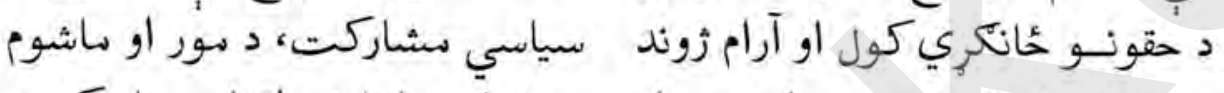

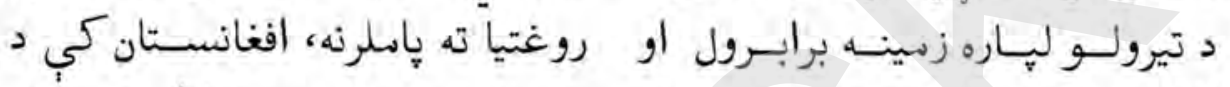

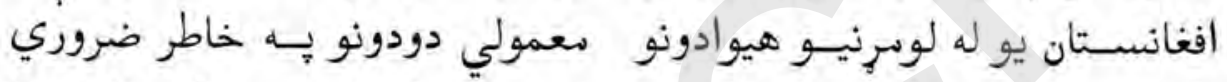

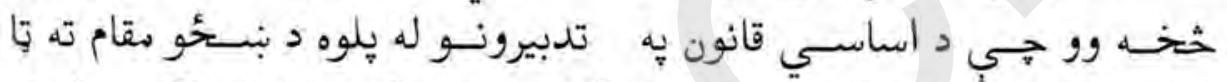

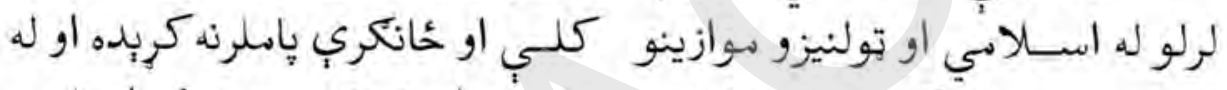

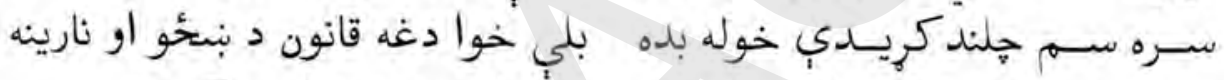

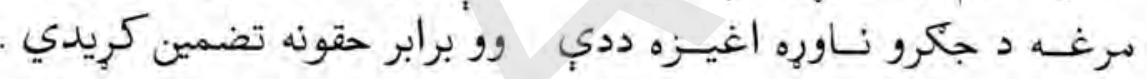

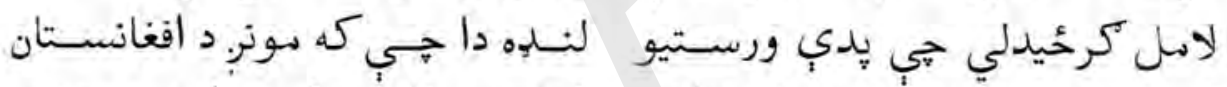

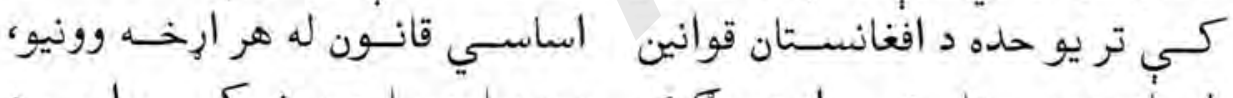

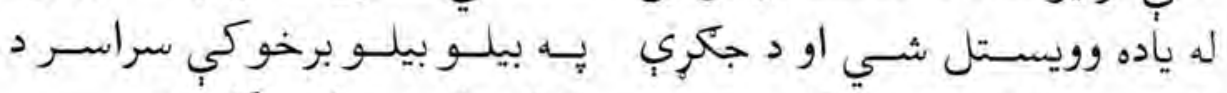

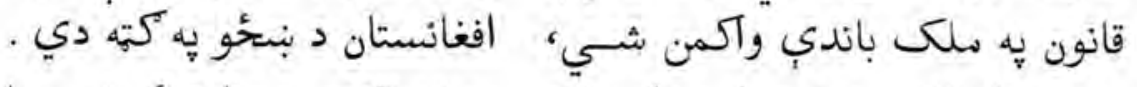

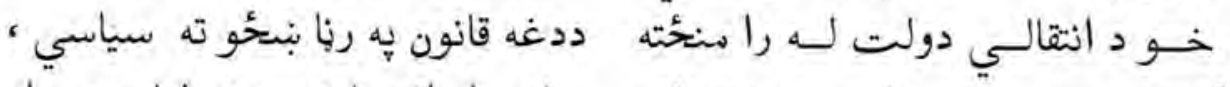

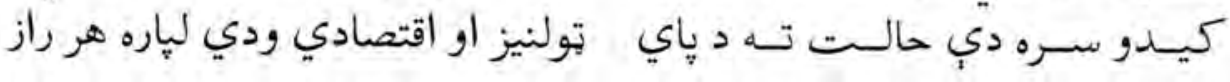

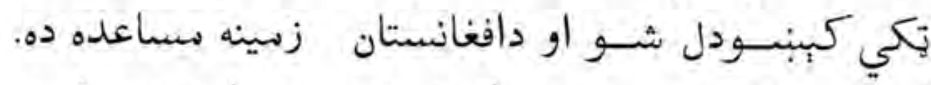

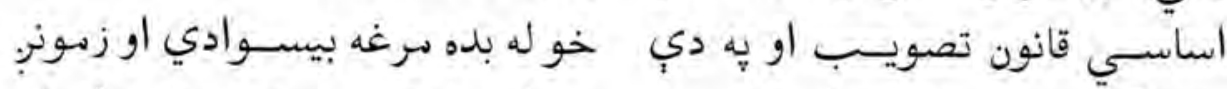

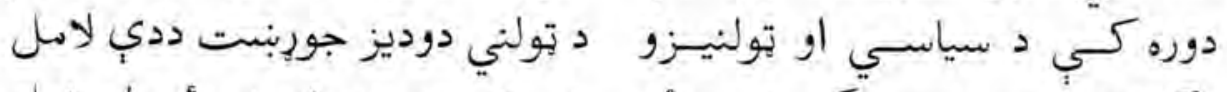

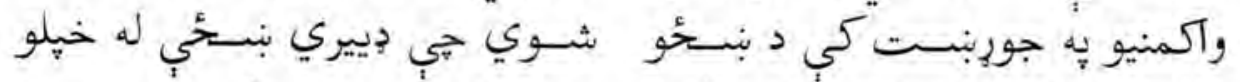

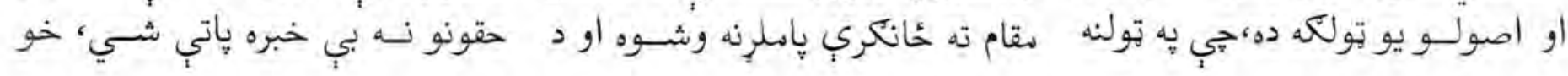




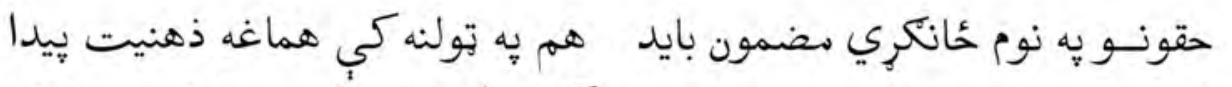

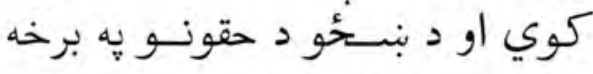
كَي هِ تولنه كي طبيعي او بنسـتيز بلولونونه راسنخته كوي.

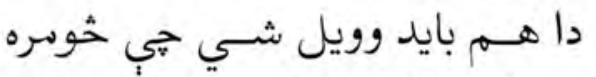

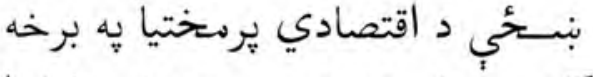

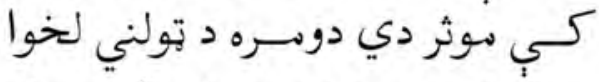
منل شـوي ندي، خو له نيكه مرغه دونه

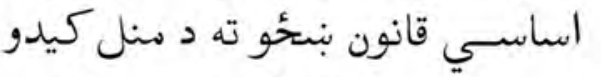

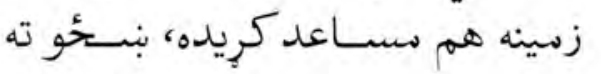

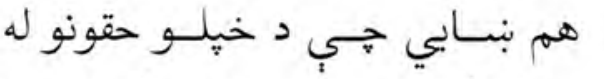

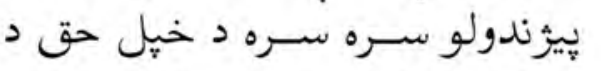

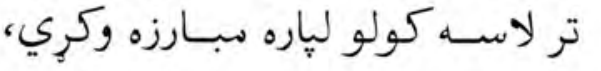

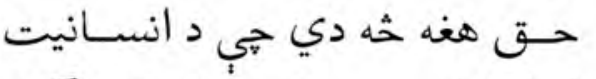
او اسلاسيت يه نوم بندئو ته وركري شوي دي او بايد تر لاسه شي.

تدريس شي.

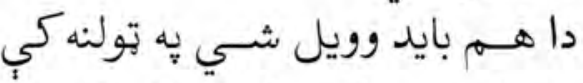
حق وركرل شوي، د بـ بيلَي يه دول مونجب.ملي او بين المللي تولني ته زئن

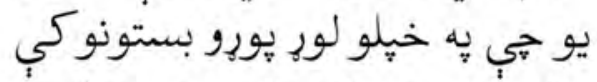

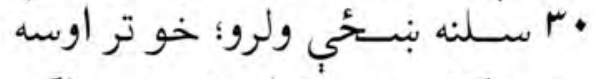

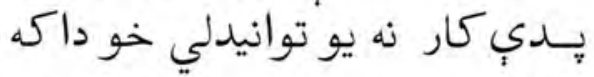
دا زمنه هم تر سره شي ددي خبري

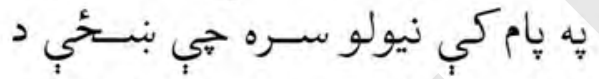

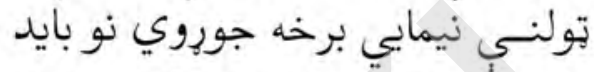

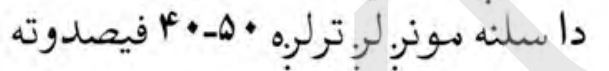

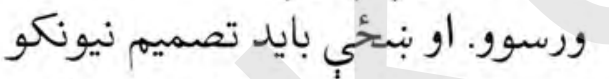

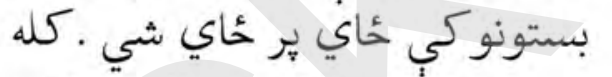

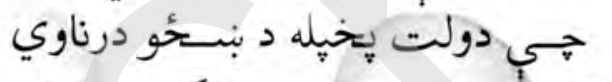

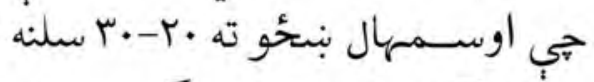

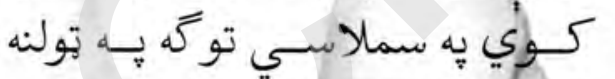

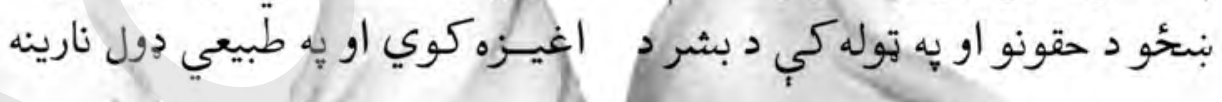

دا هم بايد وويل شسي خي يوهاوي

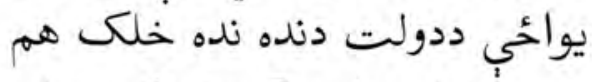

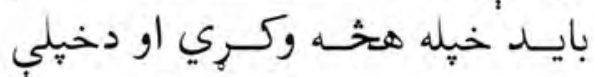

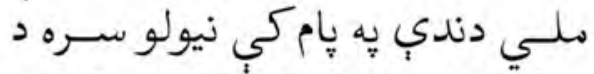

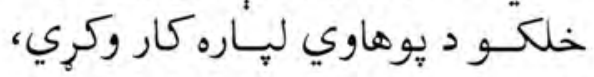
كله جي يو اوسيدونكي ونه يوهيري

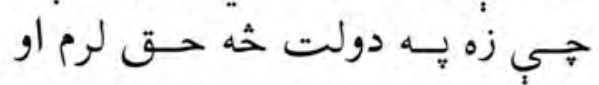

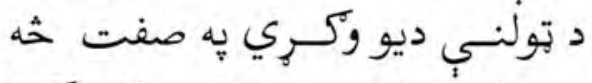

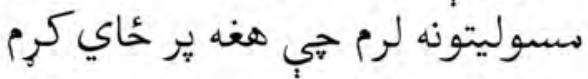

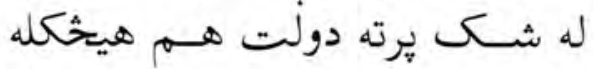
دغه اوسيدونكو د حقوقو رعايت او دون درناوي نه كوي.

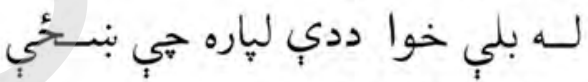
د خيلو حقونو نه خبر شـي، رستي دئى

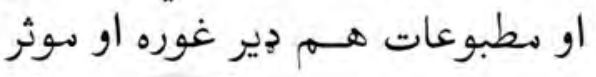
دي او د يــو بنسـتيز كار يـهـ عنوان

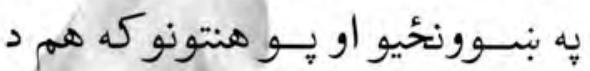




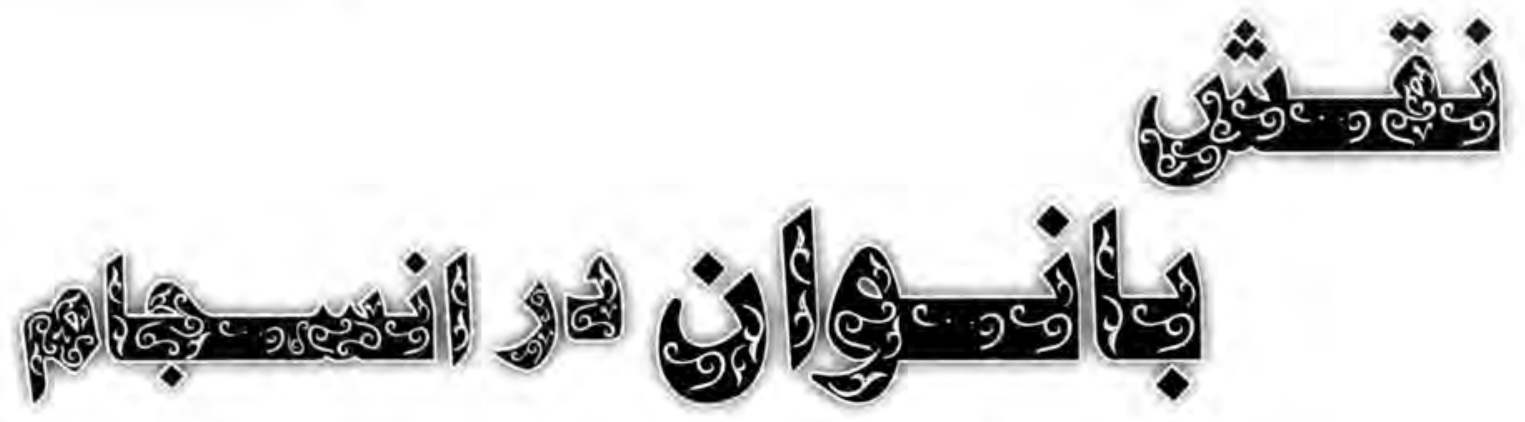

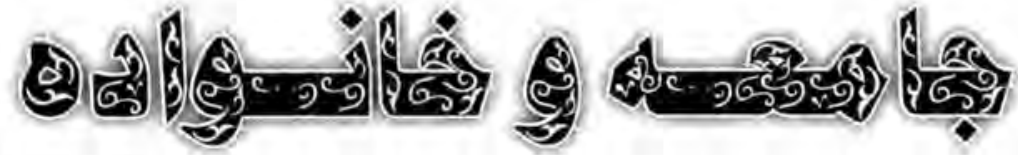

حسينا رثــــيد

زنان به حقوق اصلى و طبيعى شان نرسند. زنان با ايجاد محيط خانوادة سالم مى توانثذ بستر مناسـبى را براى تحقق جامعه انسانى قدرتمند،

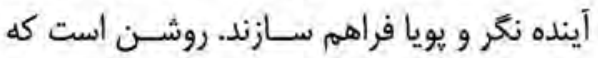
بـدون ايجاد خينيـن محيطى، جامعهُ انسـانى از لحاظ عاطفه كسســته و از لحاظ معنوى و روحى لهى به شـدت آسيب بذير خواهد بود و جامعه يى كه

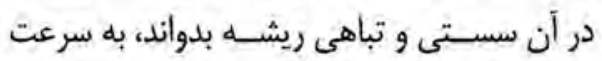

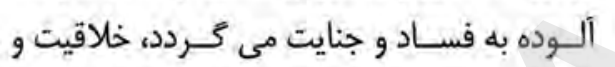

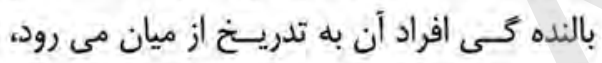

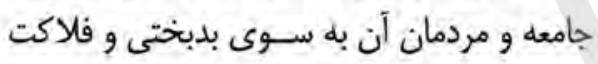

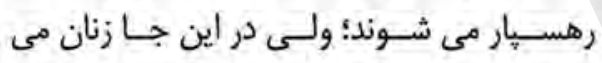
توانند به عنوان عضـــو اصلى و محور خانواده دو دون وظيفه مهم مادرى و همسرى را به عهده بخيرند

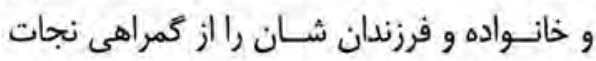
بدهند.يس وجود خانواده سـالم و خوشبخت، مى ولى تواند متضمن جامعلَ مرفه و سالم باشد.

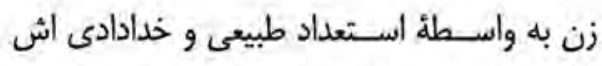
قادر اسـت نياز هاى عاطفى و معنوى خانواده را برآورده سـازد و بستر هاى مناسب كمال و رشد

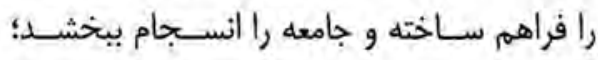
امازمانى كه جامعه فاقد اين حالت عاطفى باشـــد جامعه خمود و داراى محيط خشـك خواهذ بود؛
عظيمى رادر توسـعه و ييشـرفت جامعه از خود

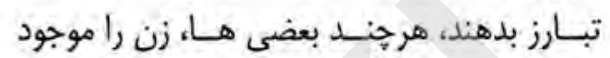
ضعيـف و ناتـوان تعريف مــى كنتد:ولى زنان از لحساظ توانايى هاى فكرى و انديشــه مى توانند همسان با جنس مخالف خوبتر و درست تر نقش خود را ايفاء نمايند. اين زن استس كه علاوه بر وظيفهُ اصلى اش كه وظيفه مادرى و همسرى است، توانايى انجام هر

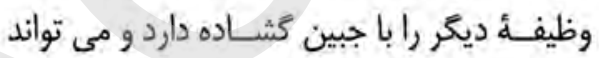

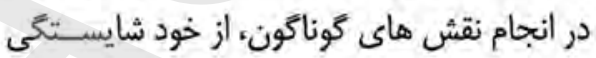
نشان بدهد.

خداونــــ (ج) زنــان را بازيورعطوفـــ، مهربانى،

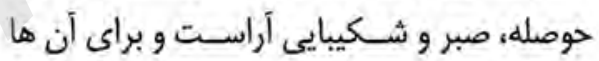
حقوقىى جون زنده گى، رفاه و آسـايش، تعليهم و

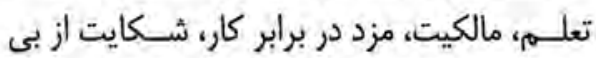
عدالتـى، دفاع از حقوق خود و اشـــراك در امور اجتماعى را اعطا نمود. زنان علاوه بر انجام نقش اصلى شان، مى توانند

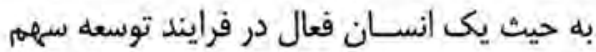

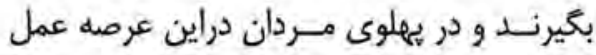
نماينــد. به صراحست كفته مى توانيـم كه هيج

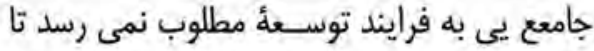
حضــور و نقش زنان در آن جامعه هويدا نكردد و
نظــر بــه حقوقـى كـهـ در قانسون اساسـى و سـاير قوانيسن دولـت

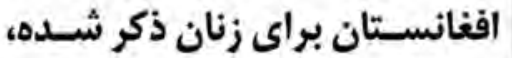

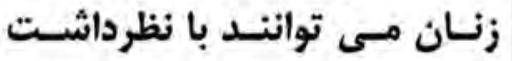

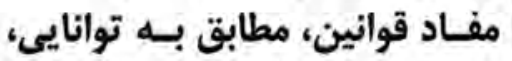

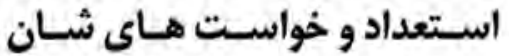

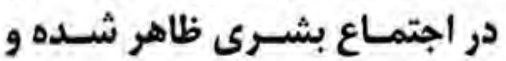
براى رسـيدن به مقاصد ثوناتون

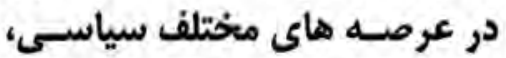

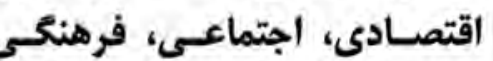

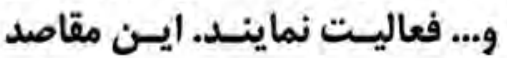
مى تواند مشـمول اهداف مختلف شخصى و غير شخصى باشد. اهداف شـخصى: مثلاً زنى براى برآورده ساختن خواسـت ها و نيـاز هاى خودش مسى خواهد از مناز

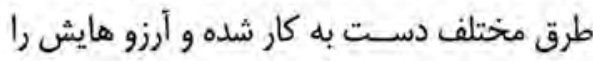
برأورده سـازدئولى اهداف غير شخصى اين است

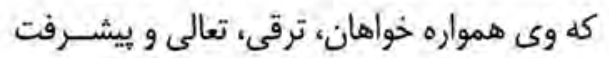
مردم و كثــورش بوده و مى خواهد كه كشورش بلندترين قله هاى ترقى و توسعه را بييمايد كه در اين عرصه نقش زنان به خوبى هويدا اسـت؛زيرا

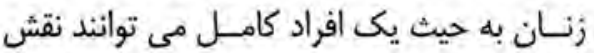


كه نقش بسـيار عظيم اسـت. زنان با حوصله و أيندة اجتماع خواهد شد و از جانب ديخر شخصيت

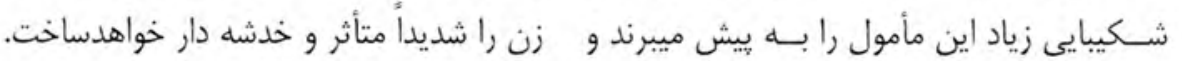

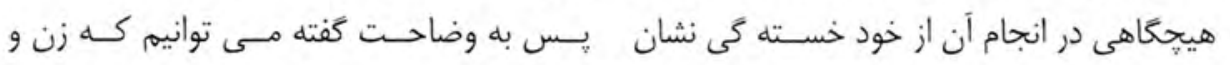

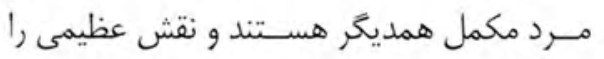

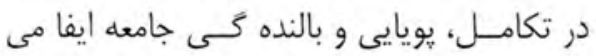

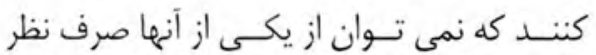

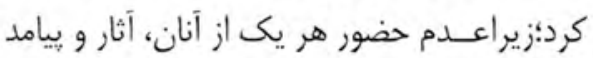
هــاى ناگوار خود را در خانـواده و اجتماع خواهد جامعه تحويل مى دهند.

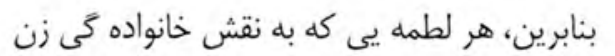

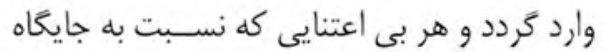

هر خند در برخى از زمينه ها يبشـرفت هم كرده باشـــد ؛ولى از حيث عاطفه و صفاى انسانى دهار

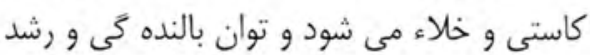
متعادل و انسجام را از دست مى دهد.

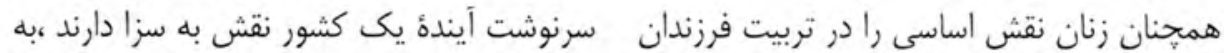

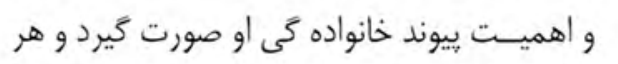
اقدامسى كه در جهت تعضيف جايگاه خانواده كى زن باشد، داراى أثار منفى زيادى است كه متوجه
شان كه نسـل آيندة يك كشور مى باشند، دارند

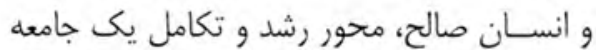
اسـت و تربيت انسان صالح نيز مســتلزم برنامة

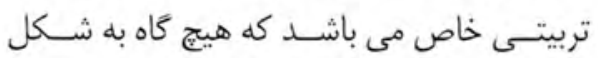

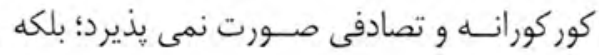
در اين عرصه باز هم نقش زن برجسته مى كردد

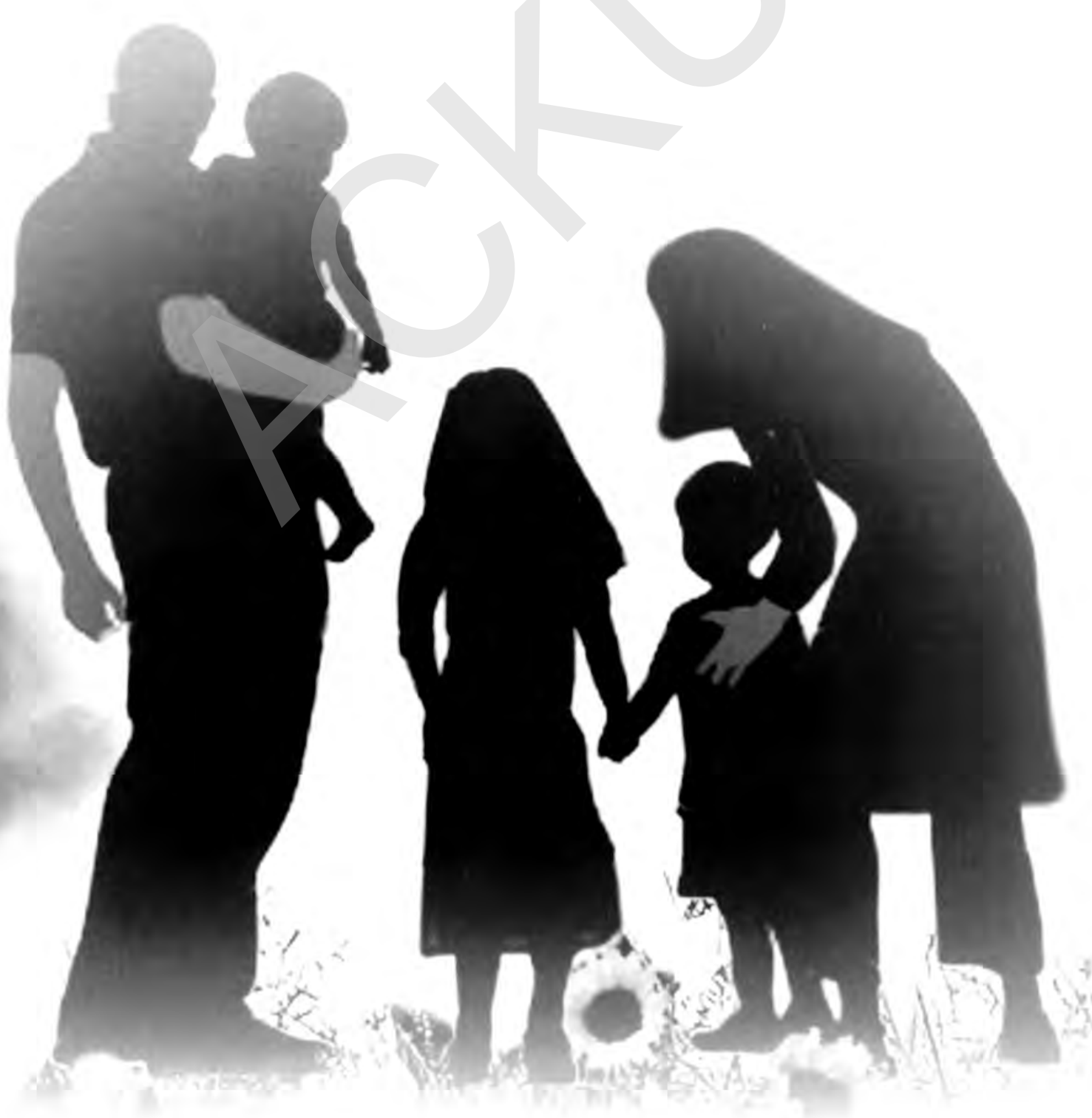



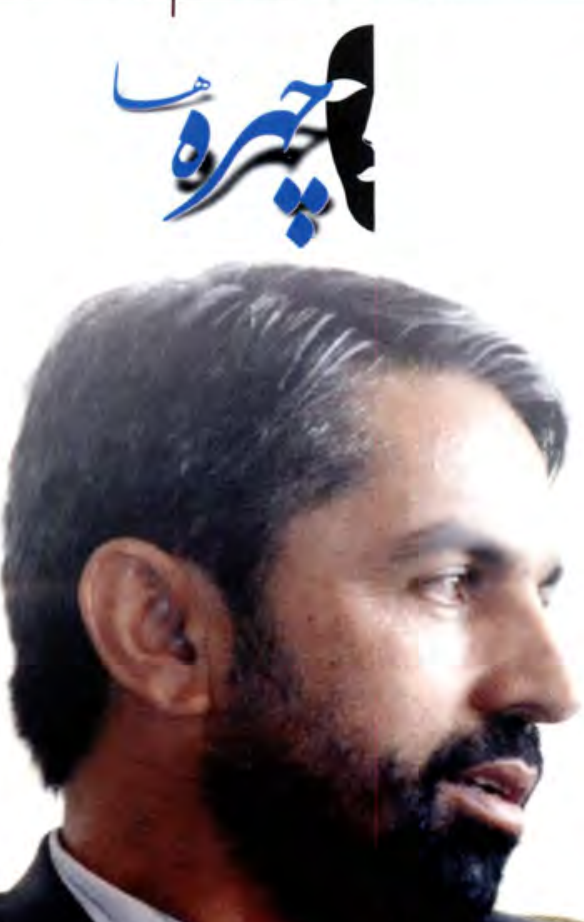
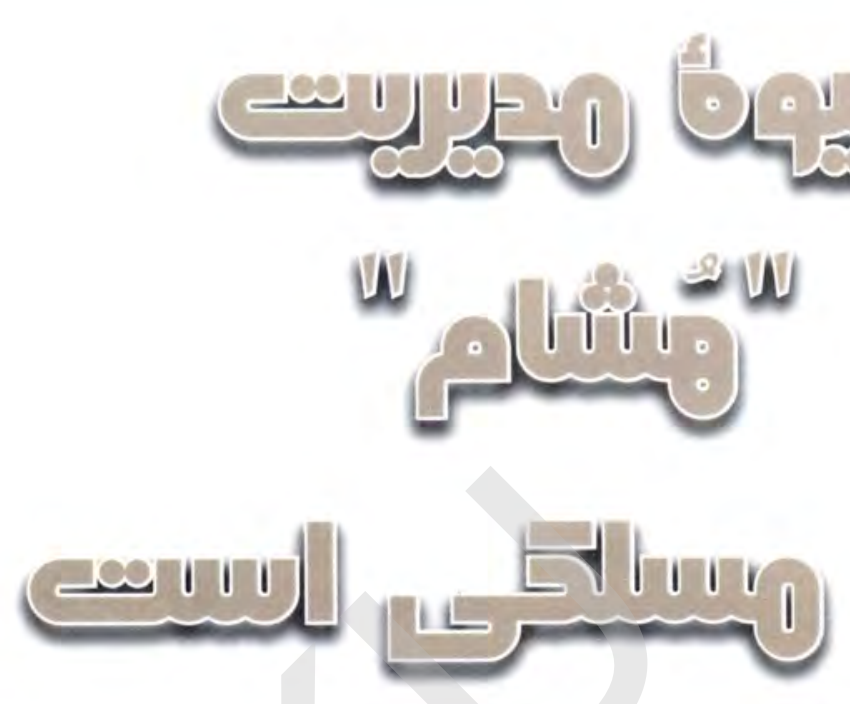

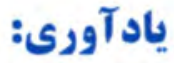

كرده و اجازه خواسـتهم تا وارد اتاق شــوم. ديدم

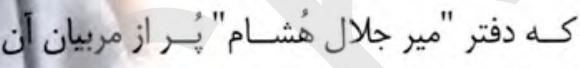

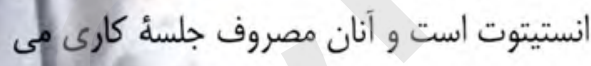
باشند. مربيان بخش هاى كوناگون انستيتوت هر يك مشكلات شان را مطرح مى كردند و هُشام

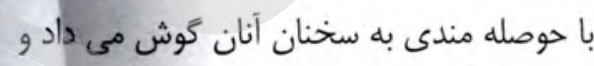

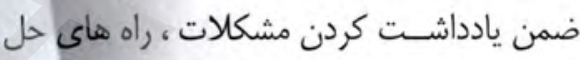
آن را مطرح مى كرد.

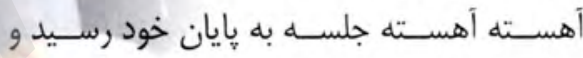
شعارى كه در ديوار رياست انستيتوت نصب شده بودتوجهم جلب كرد كه نوشـته شده بود: "ما در

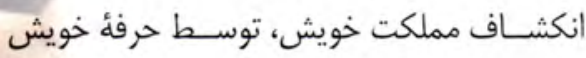

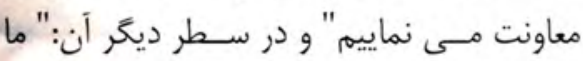
در بازسازى و نوسـازى كشور خود توسط حرفه خويش كمى مى نماييم" نوشته شده بود.

\section{محيط آموزشى:}

جلال مانند ديكر اطفال در ســن هفت سـالكى شامل مكتبى به نام "متوسطة دهنه" مى شود و

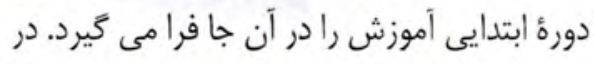
آن زمان جلال كودكى بيش نبود و نمى دانست أنس

\section{محيط خانواده كى:}

"مير جلال الدين هُشام" فرزند "ميرمحمد امين"

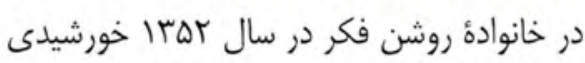

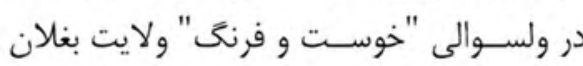

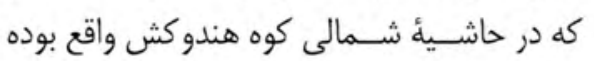

دريى شناسـايى مديران مؤفق خدمات

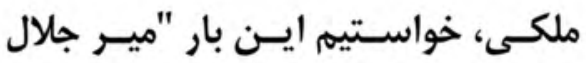

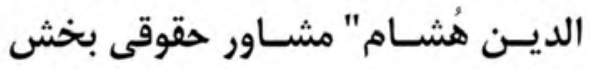

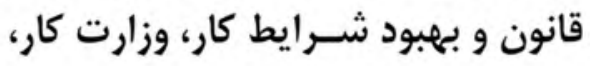
شـهـدا و معلوليـن و امـور اجتماعـى را زمان كفتكو فرا رسيد، روز شنبه، مانند روز هاى

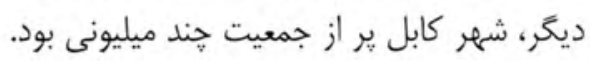

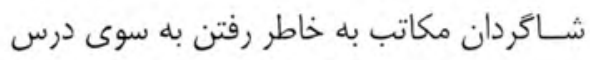

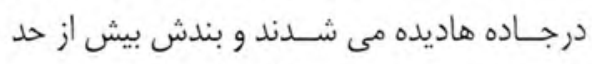
راه ها نيزمثل همه روزها از خالش هادئ هاى هميشه

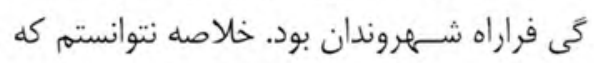

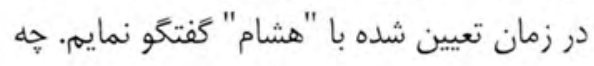
درد ســر بدهم... هي ميدان و طى ميدان رسيدم

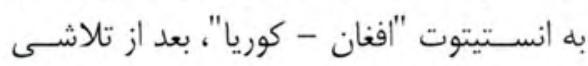

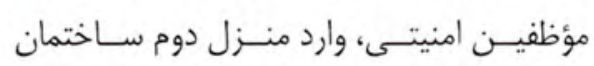
انستيتوت "افغان - كوريا" شدم. در عقب دروازه دخولى رئيس انسـتيتوت نبشته شده بود: "بدون

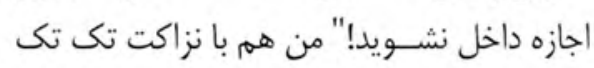
معرفى كنيم. 


\section{محيط كار:}

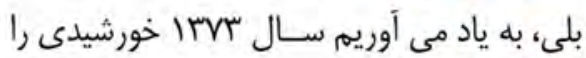
كه ديكر قشــون شوروى سابق در كشور حضور نداشـت و جلال در آن زمان كه سخت علاقه دونه منـــ خدمتخذارى به كشـور بود مى خواسـت

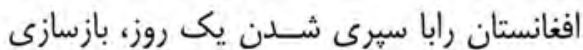
كند.

او به حيث مدير محاسـبه و سيس رئيس مالى "ن الى و ادارى در "اتحاديئ جوانان" شامل وظيفه شد.

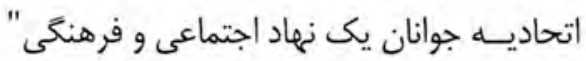
است؛ اما ديرى نغذشت كه اين اتحاديه با ورود طالبان و صدور فرمان آنان، منحل شد.

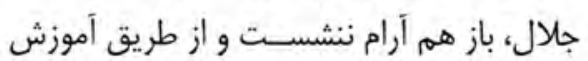

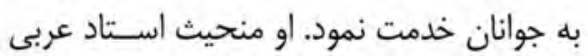

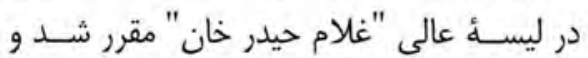

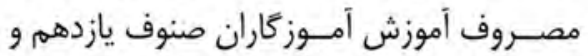
دوازدهم شـــ. آموزكاران نيز علاقمند زياد شيوه تدريس اين استاد جوان بودند.

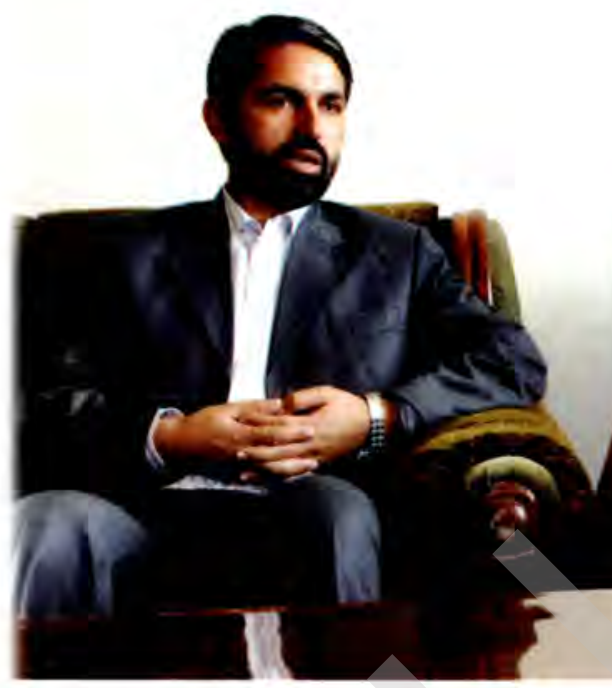

"جامعه الااسلاميه للعلوم والتقنين" مى شود.

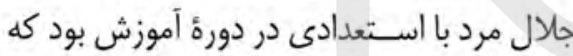
توانسـت دانشـكدة اقتصاد را به زبان عربى فرا كيرد و از آن دانشــاه به سـويةٌ ليسانس فارغ

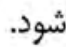

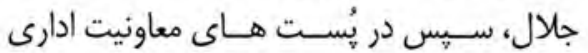
دارالعلـوم عربى كابـل، مدير خدمــات وزارت

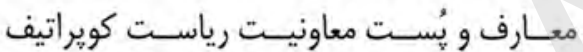
معارف ايفـاى وظيفه نمود تـا زمانى كه دولت مُوقت ايجاد شــد و وزارت امور جوانان تشكيل يافت و جلال ادارٔ رياست تربيت بدنى آن نهاد را به يِش برد و بعد از كذشـت زمان كوتاهى از راز وظيفه اش استعفا داد. جـلال، مردى يُر كار اسـت كه در اين اواخر به

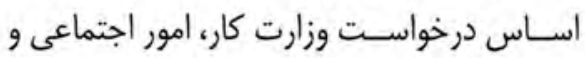

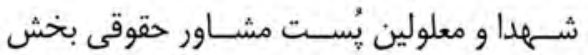
قانــون و بهبود شــرايط كار را الحــراز نمود؛ اما عال ديرى نكذشـت كه جلال به سريرسـتى مركز آموزشـى هاى فنى و حرفوى انسـتيتوت افغان - كوريا توظيف شد. جلال، بودن با آموز كاران را دوست دارد و همين اسـت كه او با علاقه فراوان هر روز صبح بيش

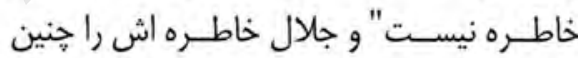

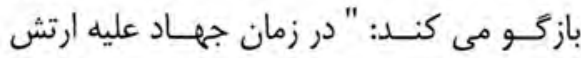
شوروى سابق، خواستم یشاور بروم. درآن زمان

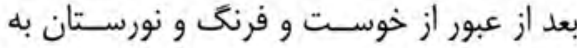

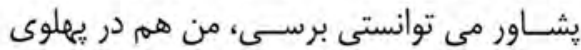

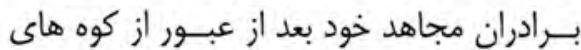
سر به فلك كشيده به كوتلى رسيدم ير از برف، ذخامت برف (ينجاه سـانتى) بود و ما در همان كوتل سرد ،بدون هيج كونه امكاناتى شب رادر

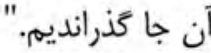

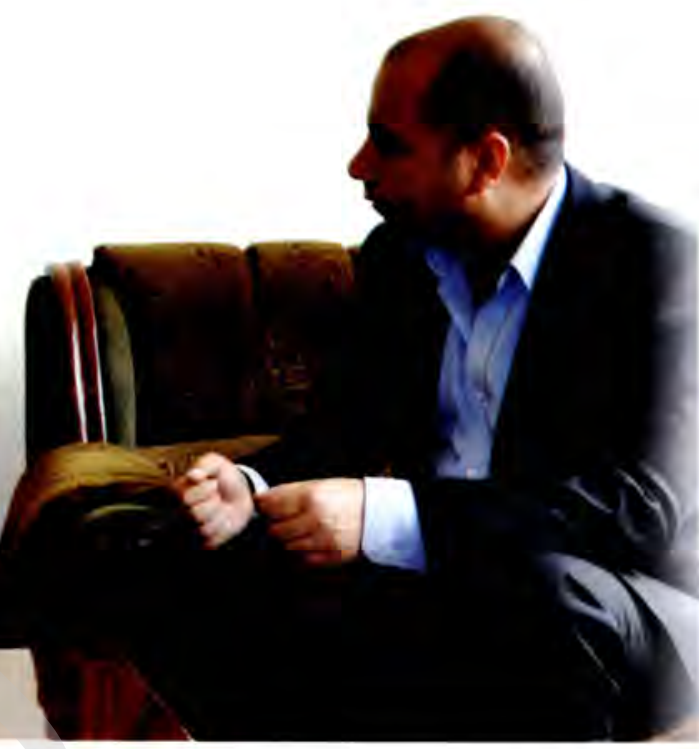

كه تهاجم حيست؟ در آن وقت ها شوروى سابق با قشــون خود به افغانستان هجوم آورد و جلال يِيش از اين كه آموزش را به پِايان رساند، ناحار

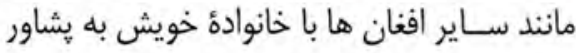
مهاجر شد تا آنكه آهسته آهسته با كذشت زمان زمان

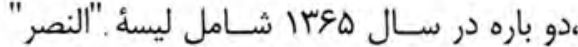
كرديد و از آن مكتب فارغ شد. جلال مى كويد: "در دورة مكتــب، به مضاميـن اجتماعى علاقه

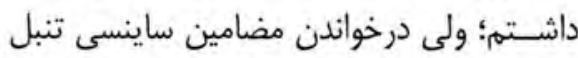
بــودم، مكر حالا بــه فرزندانم هميشــه توصيه مى كنم كه به مضامين ساينسـى توجه داشته

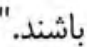
هــس از آن كه جلال از مكتب فارغ مى شـود، يشـت لب هايش سياه شتــده و جوانى است كه

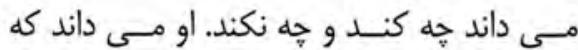
افغانسـتان در بهلوى جهــاد در برابر بيكانكان، نياز به كادر نيز دارد. وى شامل يكى از آكادمى

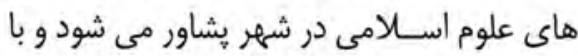

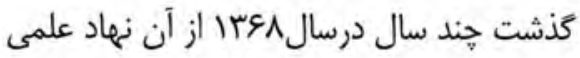

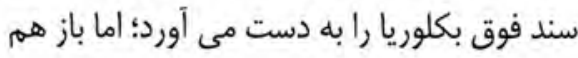

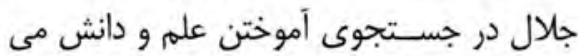
كردد تا آن كه شـامل دانشكده اقتصاد دانشكاه 


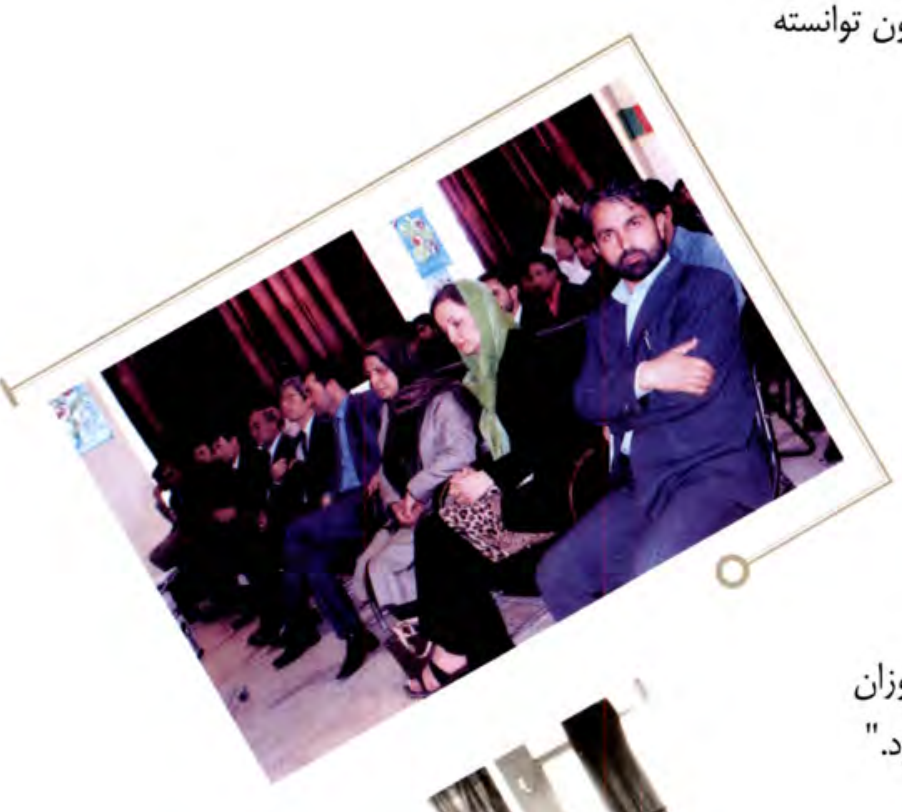

دانسته مى كويد: " هُشام از حندى به اين سو

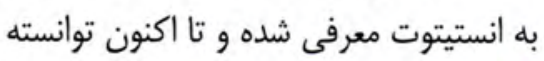
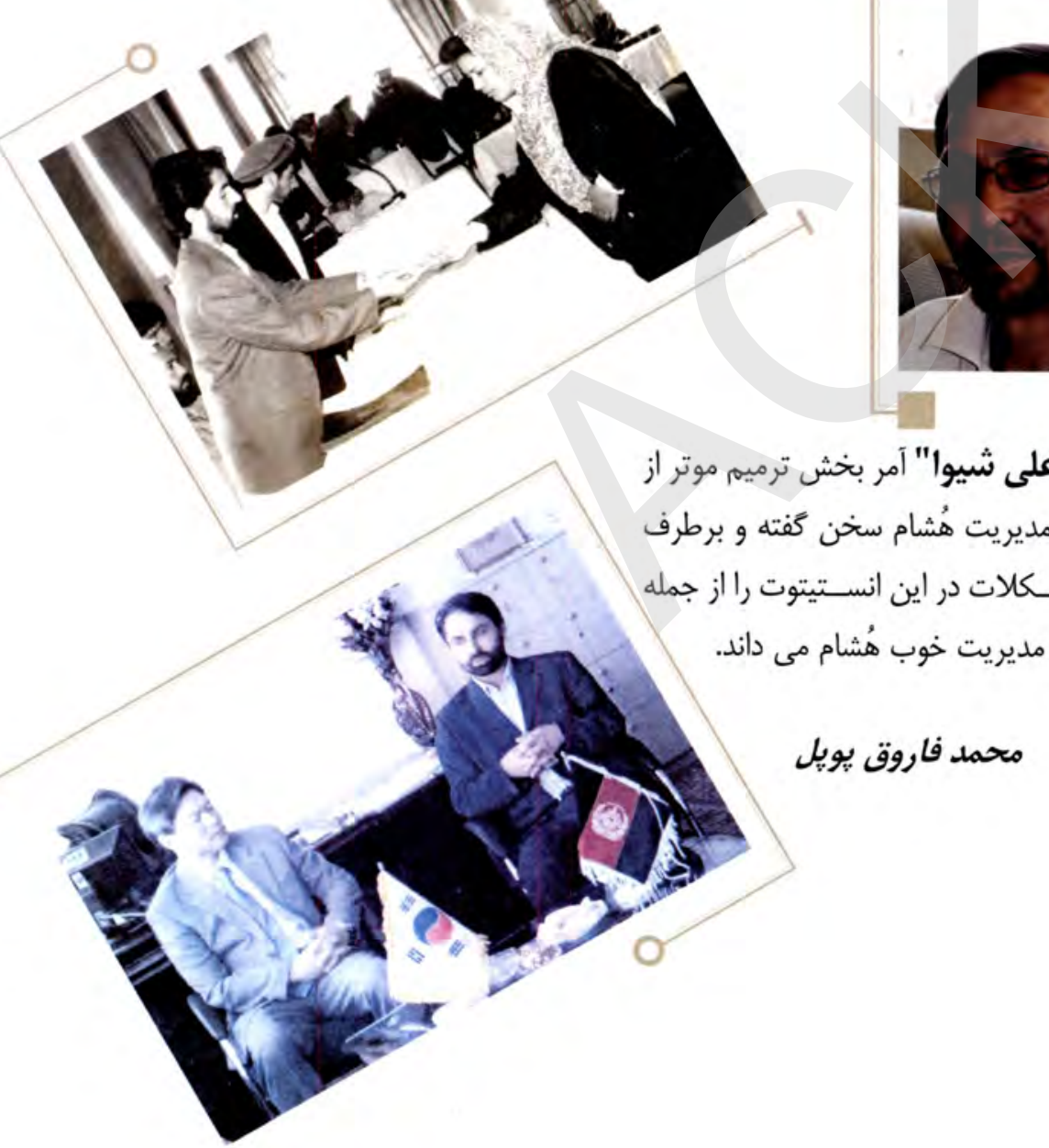

از همه وارد انسـتيتوت مى شود و از جريان ياكى

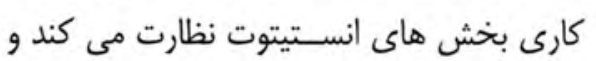

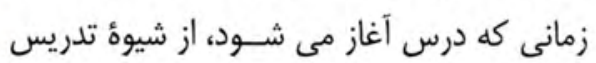

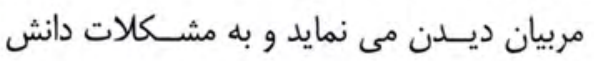
أموزان نيز رسيده گى مى نمايد.

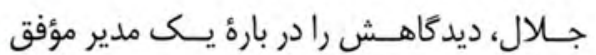

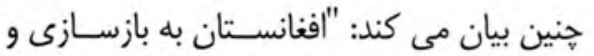
يشت كار ضرورت دارد ببنابراين كنترول، نظارت و ارزيابى سبب مؤفقيت يك مدير مى كردات دارد."

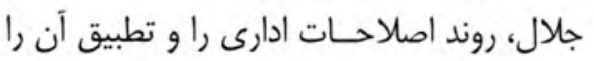

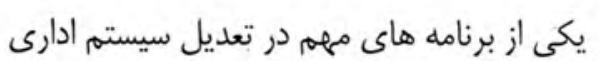

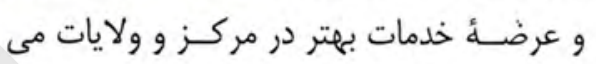
داند.

ويرُه كى هاى مير جلال الدين هُشام

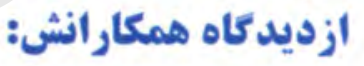

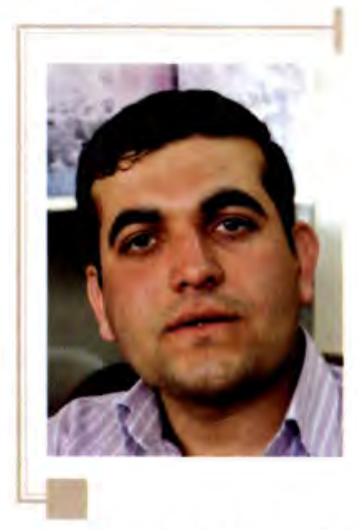

"سميع الله ماهر" آمر بخش كمييوتر و مربى انستيتوت افغان - كوريا در مورد شيؤ مديريت

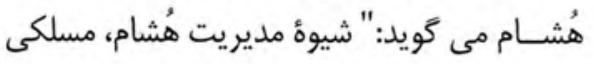

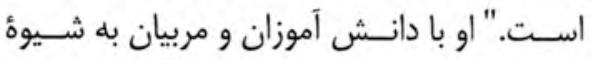

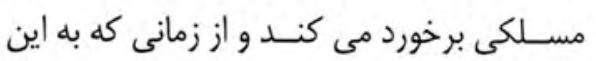
انستيتوت معرفى شده، توانسته زمينهُ آموزش را كانه براى مربيان انستيتوت در داخل و خارج از كشور

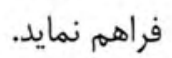

"انجنيـر دُرجان" آمر برق انسـتيتوت افغان

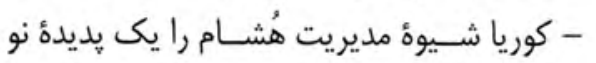




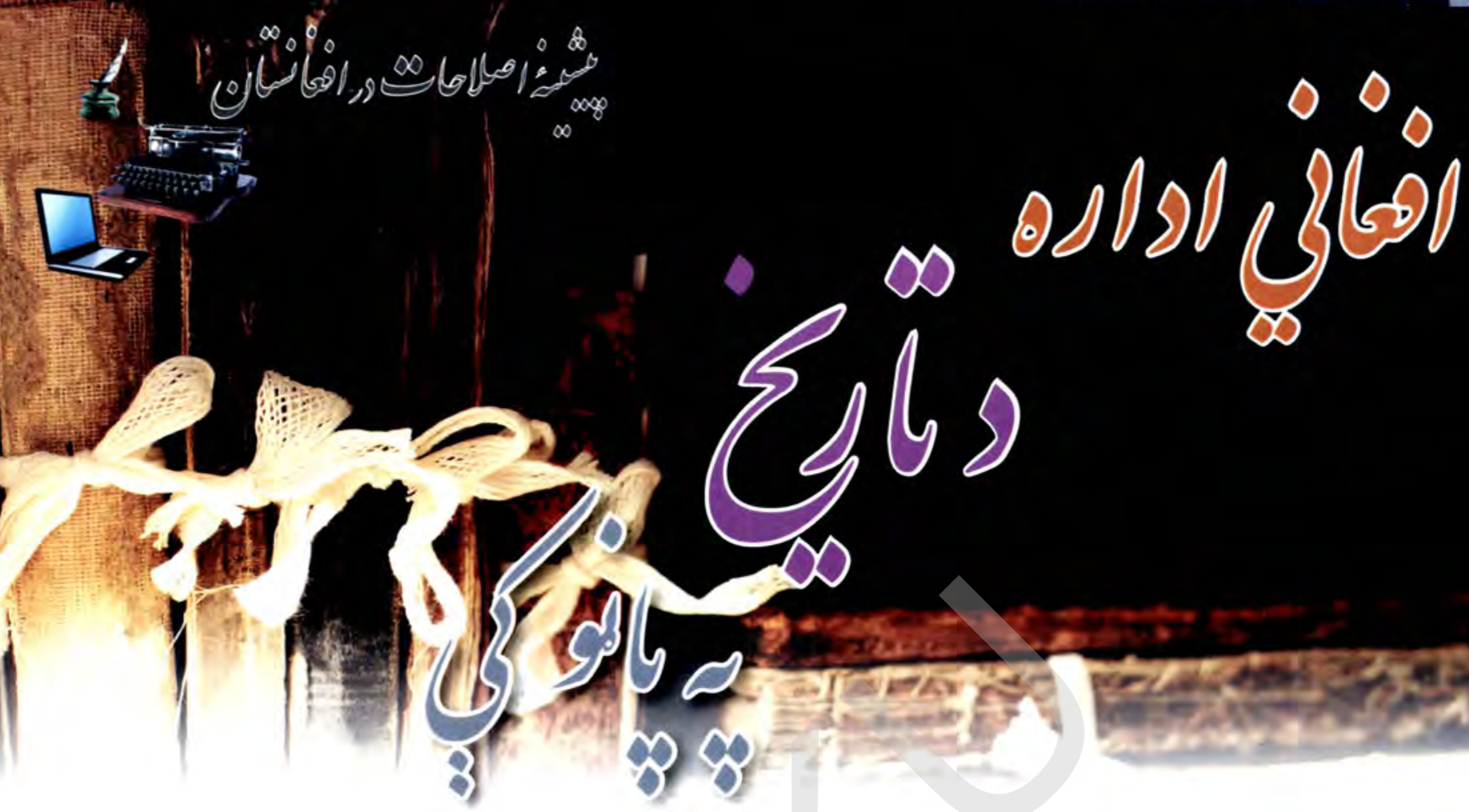

د تيري ليكني به دوام

لازنــو خايونوكي كالاكناني او داسـي نور اسـتحكامات جي د برطانوي فني انجنيرانويه سلا او سشوره به ودانيزى او د برطانوي عسـكرو او ننصبدارانو

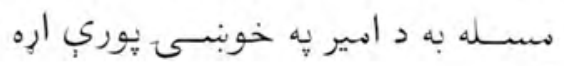
لري د سـيد نــور محمد شـاه خان لـه جيري

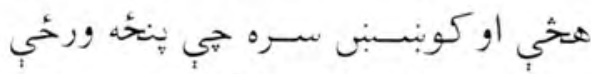

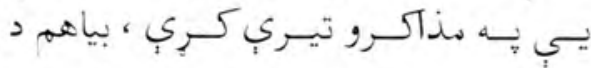

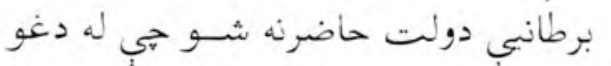

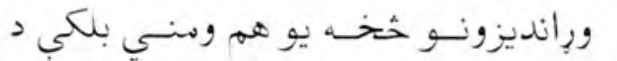

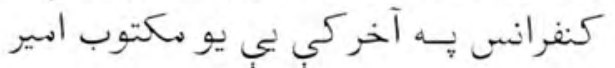
ته ورسيده جي مفادبي داوه :

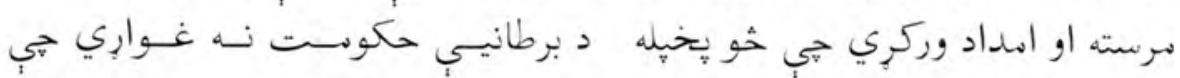

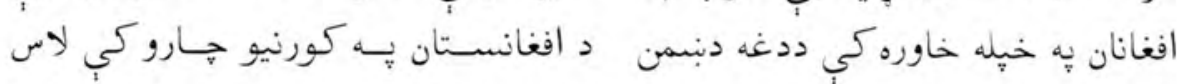

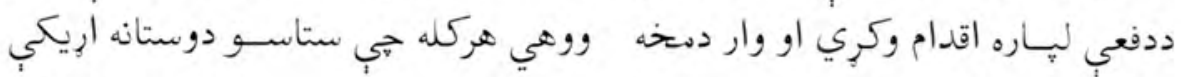

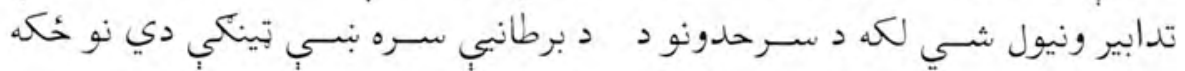

عبدالله خان وليعهدي دي تاييد شسي

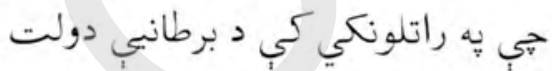

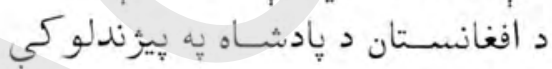
متردد نه اوسي

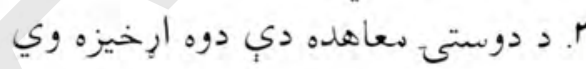
يعني كه افغانسـتان دبرطانبي دوستان دوسـتان اودنبـــنان بي خيل دبنسمنان

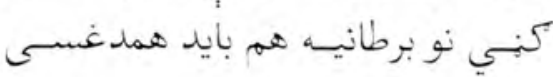
و كرى

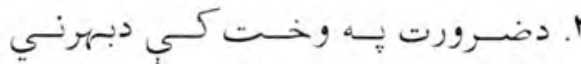
دبنسم د دفعي لِاره دوارِه دولتونه بايد

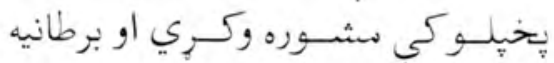

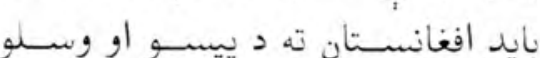

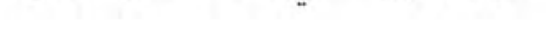

كلـه جـــ لومـرى غونسهة او د خبـرو ييـل د ســيد نـور محمد شاه فوشــنجي يه مشـرى او د د استنكار خه د هند د خارجه جارو وزير د داكتر كيـري يه ترجمانس

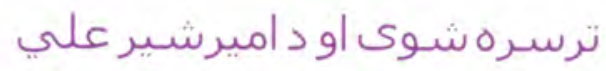

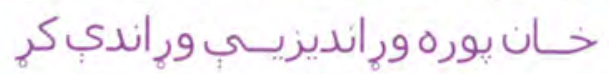

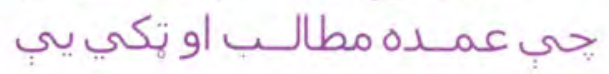
داوه ا. د برطانيـي دولــت دي هغه مرسـتي

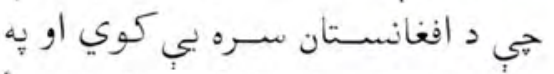
لمرى جول دي اداكوي او عالاوتأ دي دغـه درسـته د كورني يـا بهرني دوني

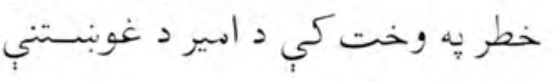
سره سم زياته شي له وحيت

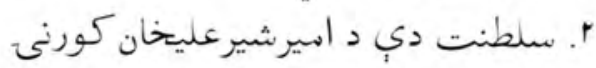
يه رسـميت وِييزندل شـي او شهزاده 


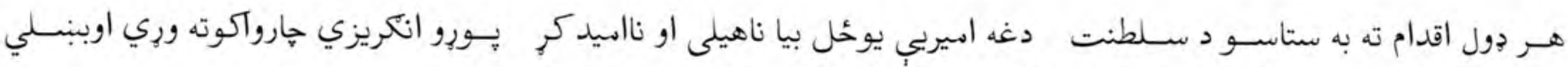

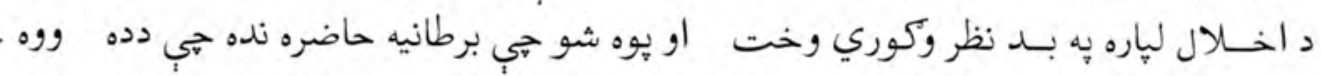

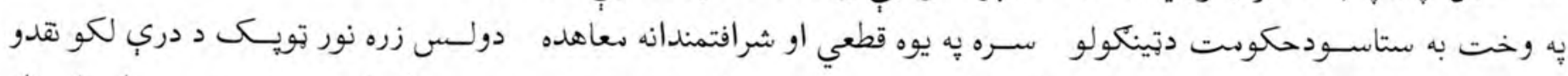

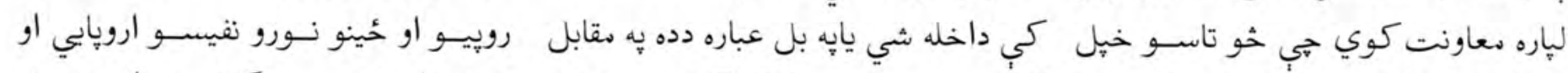

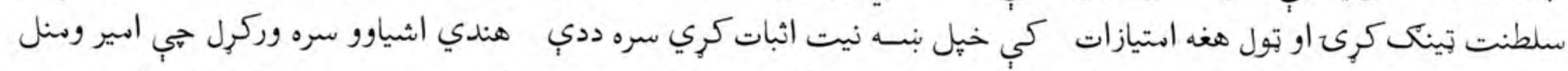

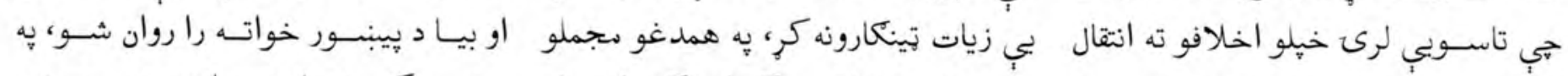

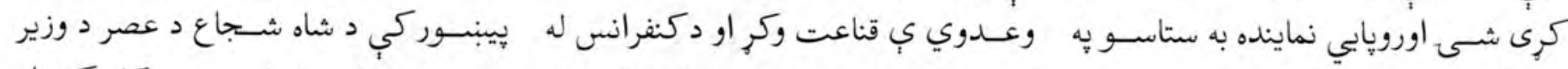

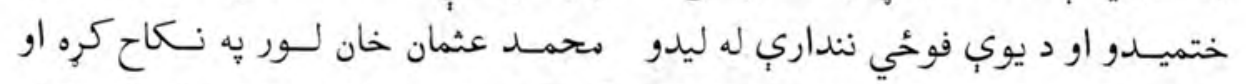

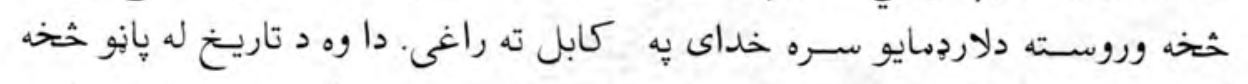

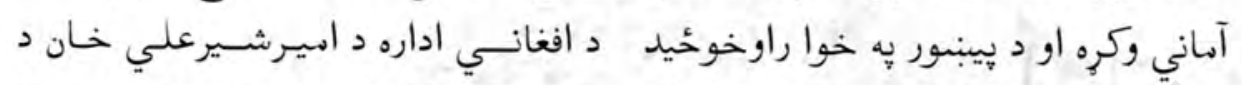

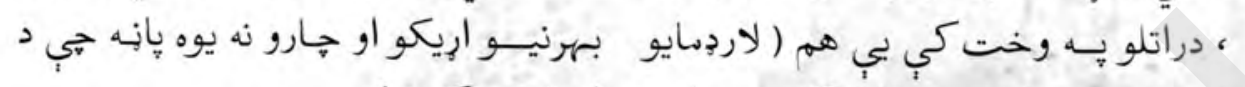

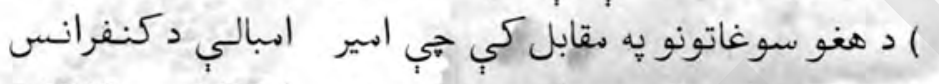

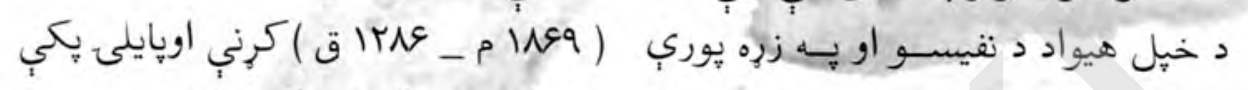

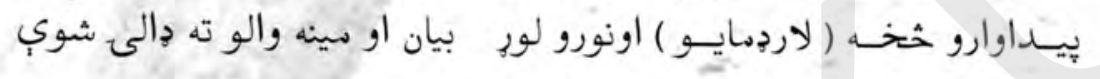

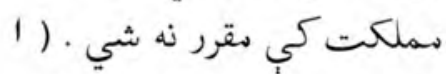

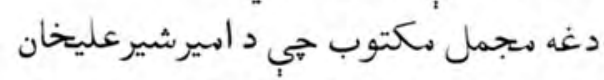

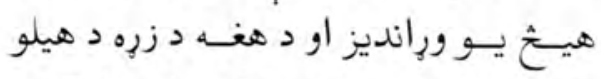

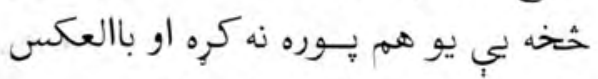

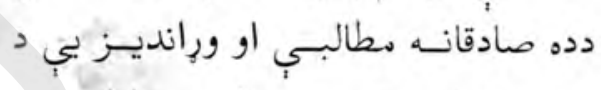

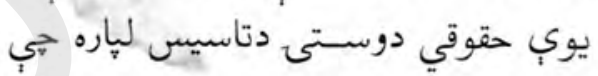
دواهداره هــم وي بي خوابه يريبنــودلي دئي

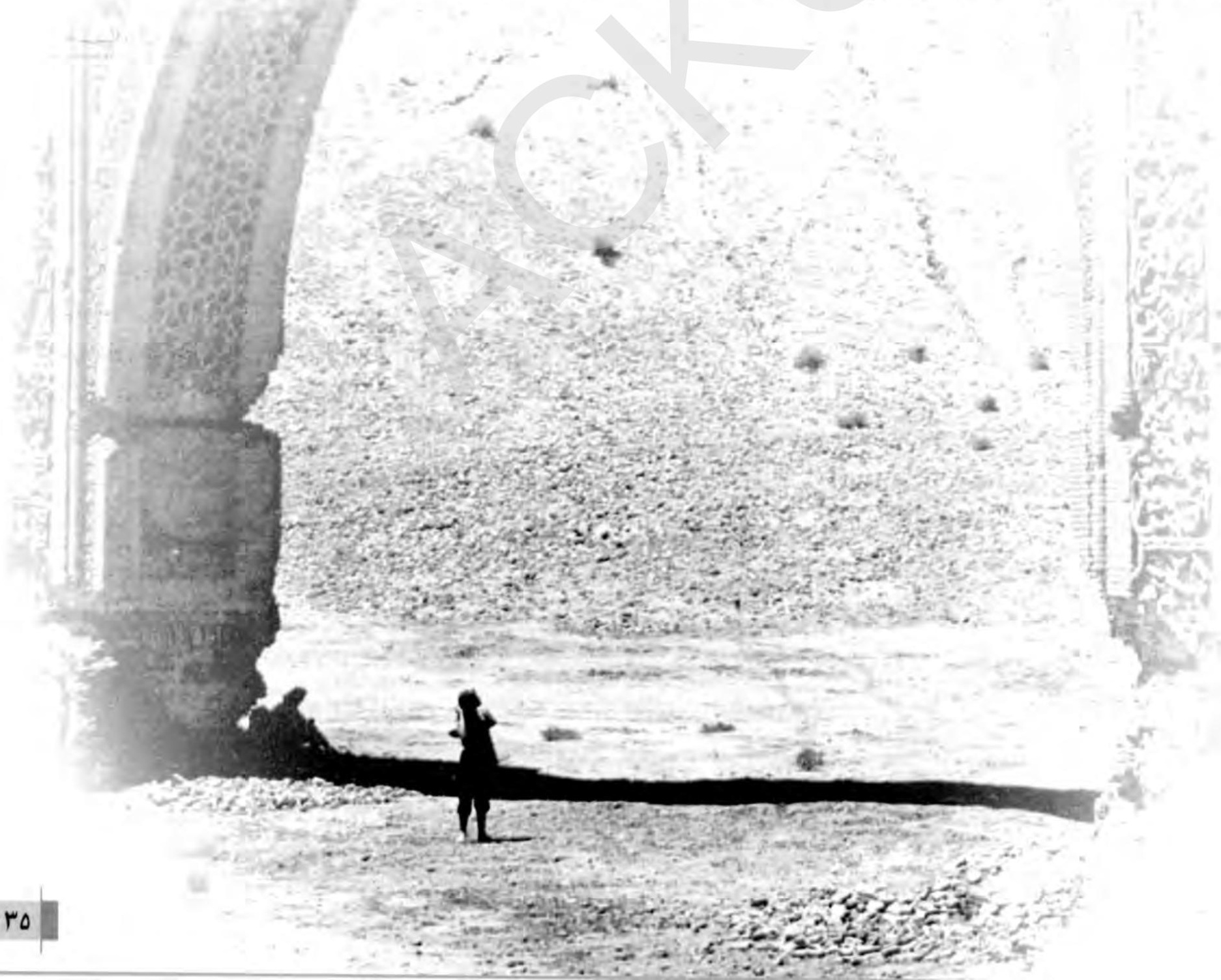



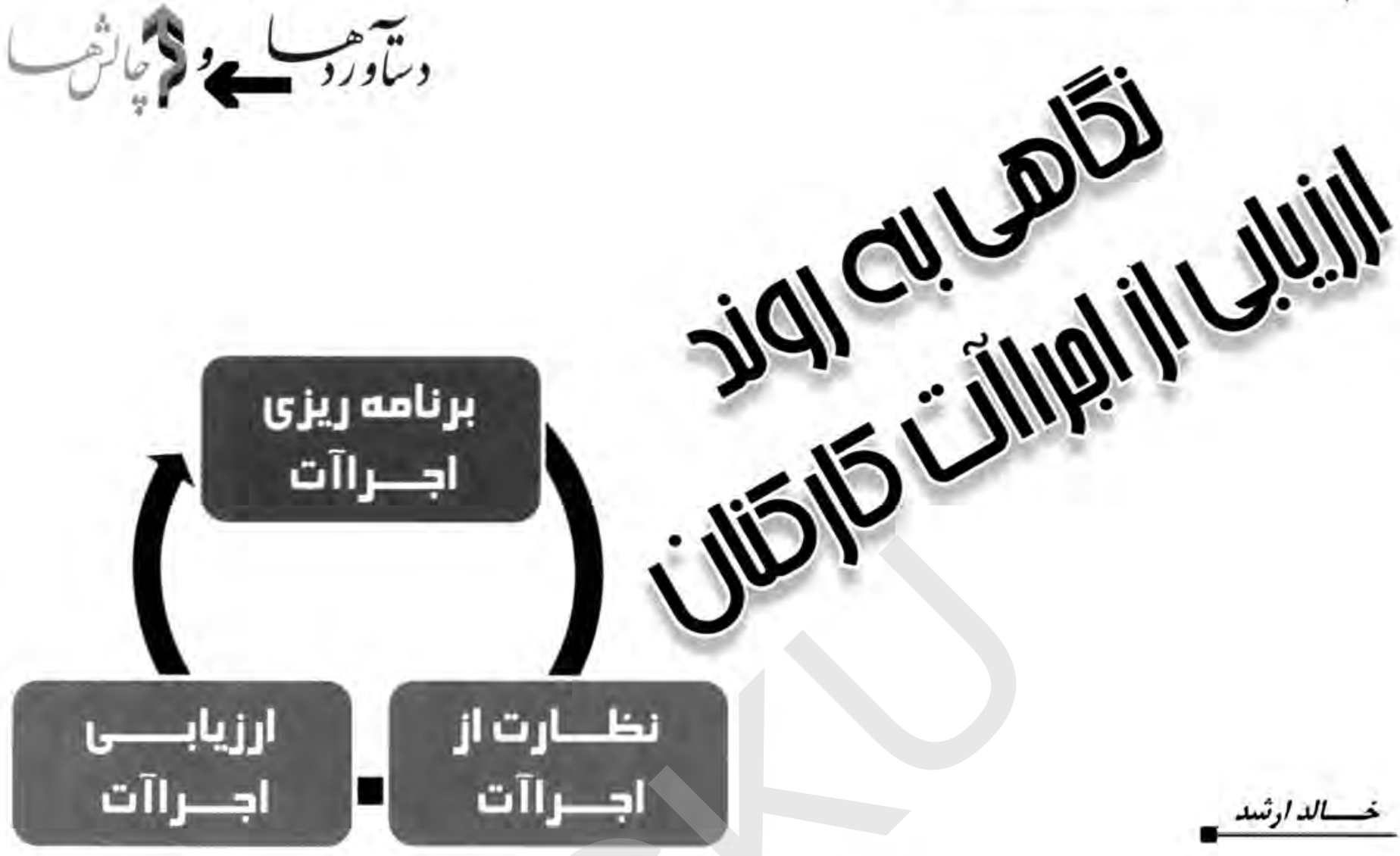
إجـ

\section{إحـإل}

خــــالد ارثشد

اجــرآت ضعيف دارد وعرضــه خدمات قناعت

$$
\text { بخش نمى باشد . }
$$

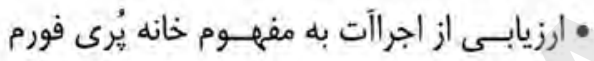

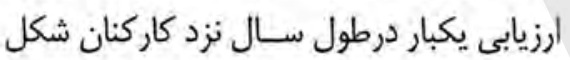
كرفته است ، نه به حيث يك يروسأه متداوم در

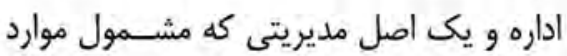

$$
\text { زير مى باشد : }
$$

I. برنامــه ريزى اجـرآآت (سـاختن برنامه هاى

$$
\text { كارى مرتبط به اهداف راهبردى اداره ) }
$$

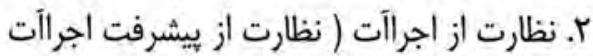
كاركنان درمقايسه با برنامه هاى كارى آنها)

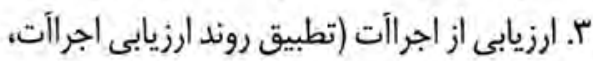

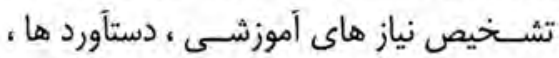

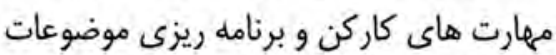

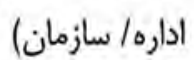

مشــكالات فـــاراه تطبيق مســـــى

טس زمينه:

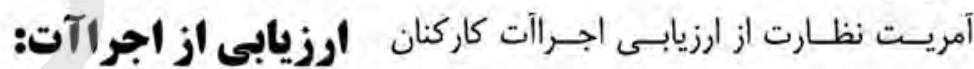

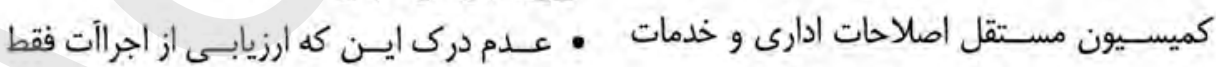
داراى دو هدف مى باشــــ دادن امتياز و ازدياد معاش كاركنان و اخراج كاركنان داراى اجرآ مدآت ملكى مسؤوليت داشته است تا شمارى از برنامه

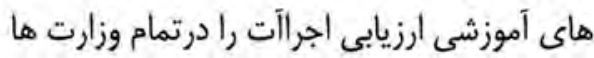
ضعيف؛ • محدوديت حمايت مديريتى وسياسـى رهبرى وزارت ها واداره هاى مستقل به منظور تطبيق مديق ونيق درست يروسهُ ارزيابى اجرآت؛

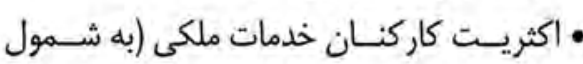

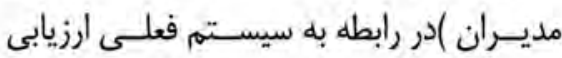

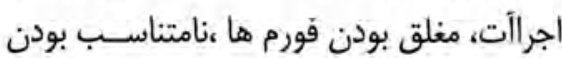
روش ارزيابى اجراآت براى ادارئ عامهٔ افغانستان

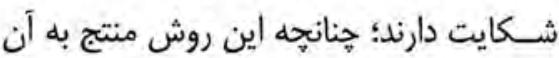

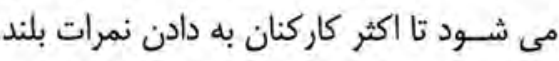

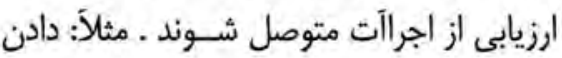

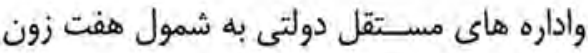
ساحوى كميسيون بركزارنمايد. تمركزآ موزش ها ها هاري

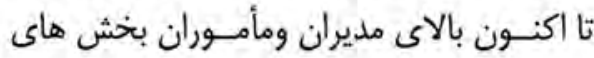

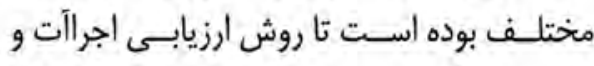
طــرز خانه يُرى فورم هـــاى ارزيابى ، برنامهُ كار

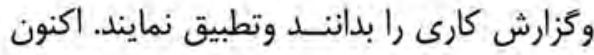
كار بيشـترى لازم اسـت تا ارزيابى از اجراآت به به بله

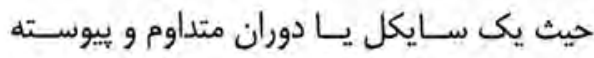

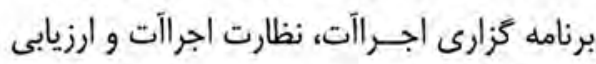

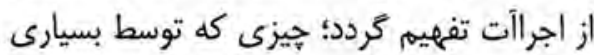
از مديران خوب درك نشده است. نمــوة سז و بالاتــــــ از آن ؛ در حالى كه كاركن 
نقش ارزنده دارد.

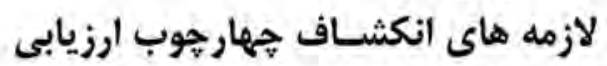

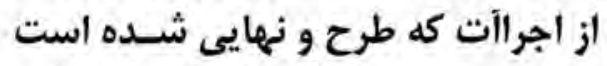
و درآينــده مـورد اســتفاده قـرار خواهد كرفت:

• كتاب رهنماى ارزيابى از اجرآت Performance Appraisal) ( Hand Book

Trainer) •رهنماى آموزش آموزكاران ( ( Guide • كتاب كوجى رهنماى اشتراك كنده كان (Participants Guide) • ينج مودل آموزشى ( Training (Modules

• تهية پِنج فلم كوتاه ويديويى كه به خاطر

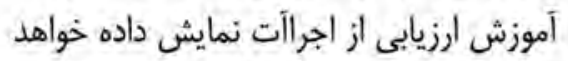

شد (Video Clips)

1. شــيوه هاى جديد تأمين كمك ومعاونت براى وزارت ها واداره هاى مستقل.

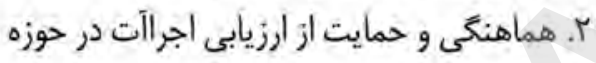

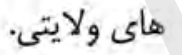
r. تهيـهُ ارتباطات به خاطر ايجاد يكى برداشـت كلى و مثبت از يروسة ارزيابى از اجرآآت.

\section{نتايج متوقعه}

نتايج زير توقعاتى اند كه از تطبيق روش جديد به دست خواهد آمد:

ا. در مــدت r تا ب سـال تمـام وزارت خانه ها

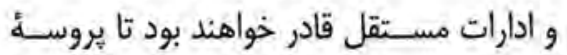

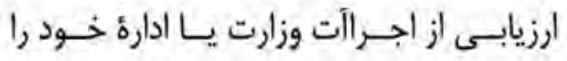
مديريت نماينّ.

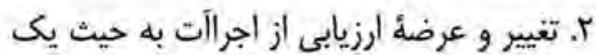

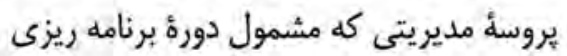

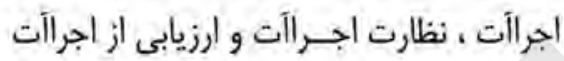
مى كردد. r. جلـب حمايت رده هــاى رهبـرى وزارت به منظور تطبيق هر خه بهتر سيستـم ارزيابى از هاز اجراآت كاركنان.

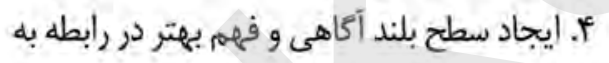
اهميت ارزيابى اجرآت جهت انكشاف خدمات ملكى (نيازهاى انكشافى و أموزشى) به مثابئ يكى راهكار، غرض عرضه خدمات اساسى وبا

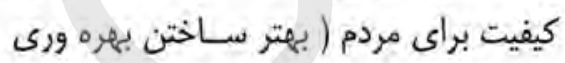
كاركنان خدمات ملكى). ه. ايجـاد و درى اين كه ارزيابى از اجراآت، اداره

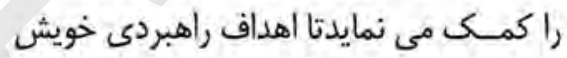
رابه دست آورده و از طريق ارزيابى از اجرآآت،

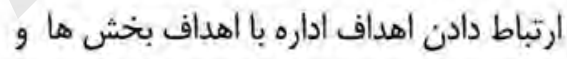
اهداف فردى ، به نتايج متوقعه نايل آيد.

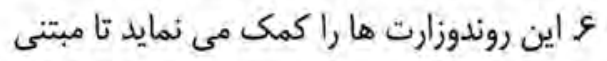
بر نتايج عمل نمــوده و حفظ كاركنان و بهره ورى أنها را تقويت بخشد.به طور مثال رياست

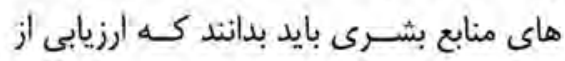

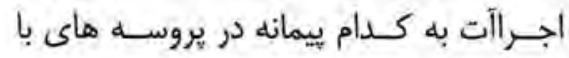

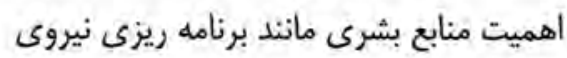
كار ، شناسـايى آموزش ها وانكشـاف و غيره

\section{فعاليت هائى كه بايد اجراء شوى:}

آمريت نظارت از ارزيابى اجرآت متعهد به أنكشاف

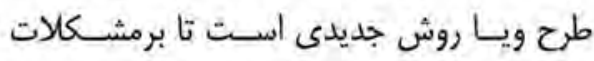
وجالش هاى فوق الذكر نايل آيد.

اين روش جديد مشمول موارد زير مى باشد :

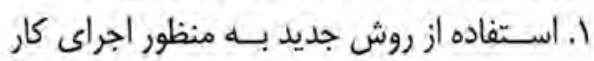
سيستماتيك(سامانمند) با هريك از وزارت ها بـا

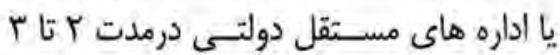
سال كارى و اختصاص دادن وقت كافى براى حمايت هروزارت يا اداره مستقل جهت تعميم داريم

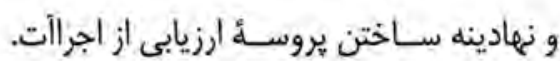
تهيهٔ يك برنامئ منظم كه ذريعه يك توافقنامه رسـمى بين كميسيون و هر يك از وزارت ها يها

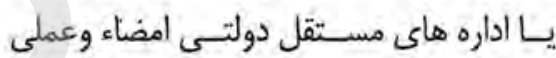
مى كردد.كاربرد أمــوزش، نمايش ويديوهاى

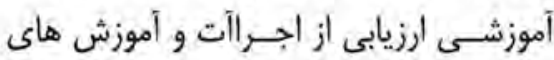

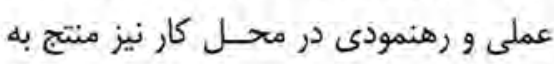
أن خواهد شــد تادرختم بروسه ، تصديق نامه مشخص به وزارت يا ادارئ مستقل داده شود . اين تصديق نامه نشـان دهندة آن خواهد بود

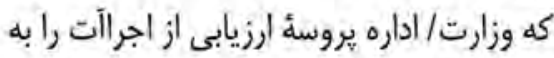
صورت مسلكى تطبيق و عملى مى نمايد.

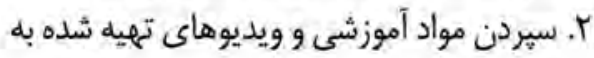
انستيتوت خدمات ملكى غرض دادن آموزش به كاركنان خدمات ملكى جديدالتقر دررابطه

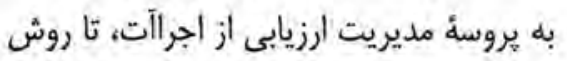
معيارى وهمكون در ارزيابى از اجرآت آستفاده كردد. r. اسـتـفاده از راهبرد مؤثر ارتباطـات به منظور متعجد سـاختن قدمه رهبرى وزارت وتطبيق

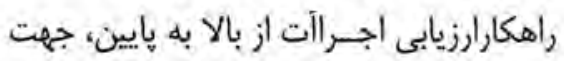
واضح ساختن مأموريت ، مقاصد واهداف ادارن با شعبات ومطابقت آن با اهداف فردى. 


\section{जी encin}

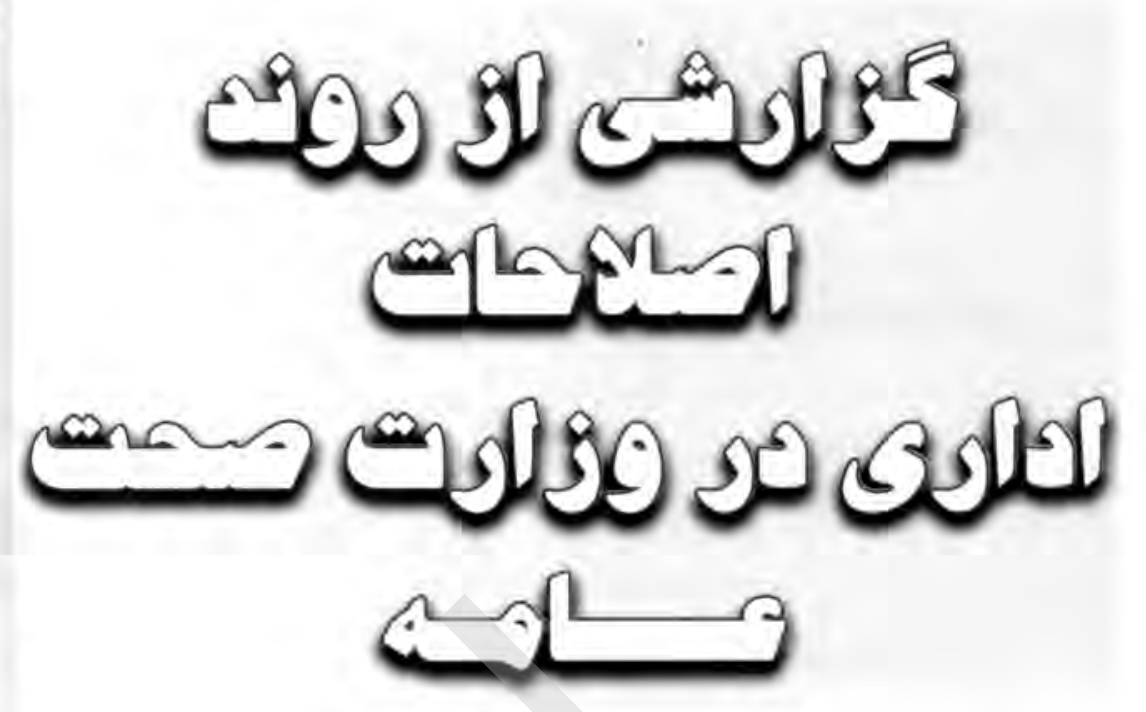

. 9 درصد بروسة اصلاحات در اين وزارت تطبيق

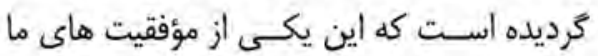
اسـت اميدوار هسـتيم در خيند ماه آينده، يروسئ اصلاحات رادر وزارت صحت عامه كاملاً نهايى بسازيم." يكـى از لازمه هاى كار مؤثر در اداره ها دانش و

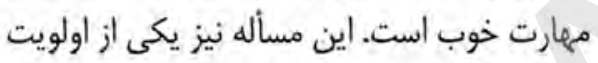

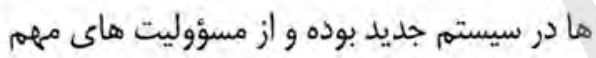
رياسـت هاى منابع بشرى است.براساس سيستم جديد، رياست هاى منابع بشرى بايد نياز سنجى مائى هاى آموزشى را در اداره ها انجام داده و كاركنان

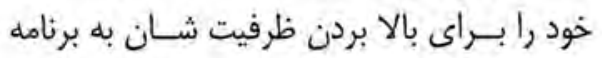

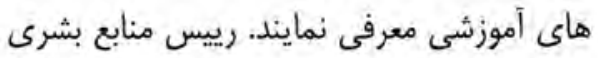
وزارت صحست عامه در اين بـاره مى گويد:"نياز سـنجى انجام شده اسـت. ما درحد توان تلاش كرديم عدالت و مساوات را تأمين نماييم. در خند سـال اخير به كمى كميسيون اصلاحات ادارى و خدمـات ملكى ظرفيت هـاى خوبى در داخل

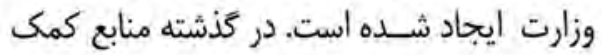
كننده بـراى فراگيرى برنامه هاى آموزشـى در بيرون از كشــور بيشنهادهاى مشخصى را مطرح
قوار ب.....

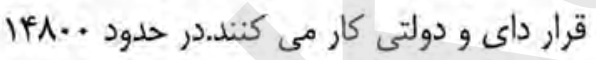

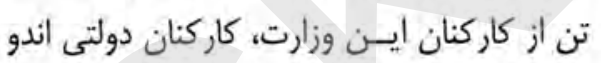
ريفورم شــده اند و باقى مانده آنها به شكل قرار دادى مصروف كار اند. ايـن كه روند اصلاحات در ايـن وزارت به كجا رسـيده است، داكتر "احسـان الله شهير" رييس ورنس

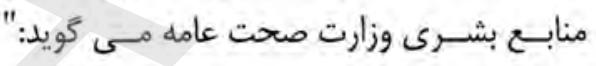

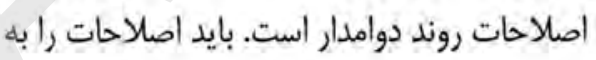
صورت دوامدار و بي گيرانه تعقيب نمود. وى مــى افزايـــ:" وزارت صحت عامه مســؤول

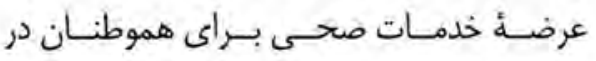
سراسـر كشور اسـت. مديريت كاركنان از سوى هـ

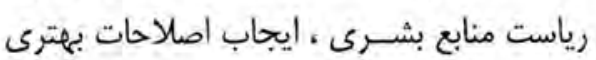

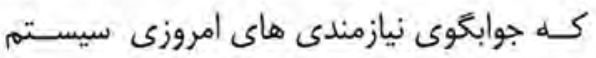
صحى افغانسـتان باشد را، مى نمايد.از يك سال بدين ســو، اصلاحات زيادى در ادارة ما به وجود

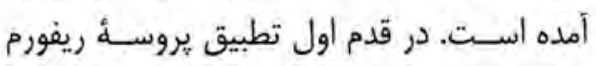

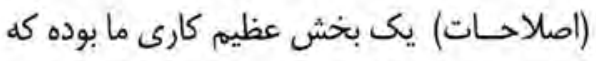
تقريبا • ودر صد آن در مدت يك سال در وزارت صحت عامه در امور صحى تطبيق گرديد.در كل
دسترسـى به تســيلات صحى حق هر

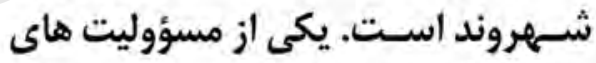

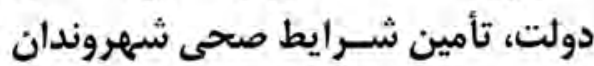

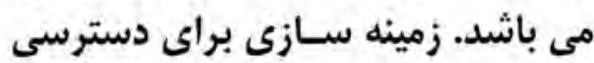

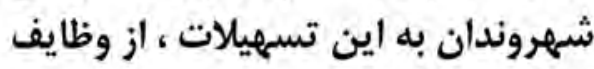
اساسـى وزارت صحت عامه افغانستان مى باشد.

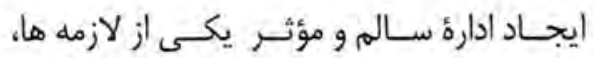
براى انجام اين فعاليت ها اسـت. به همين دليل

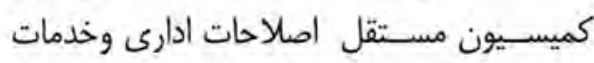
ملكى در اين وزارت از يك سال بدين سو فعاليت

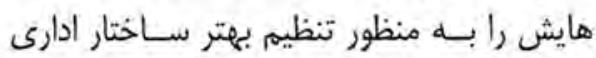
اين وزارت آغاز نموده اسـت.كار كنان يكى اداره

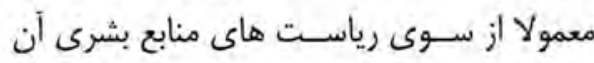
اداره مديريت مى كردند.در رياست عمومى منابع بشرى وزارت صحت عامه دو بخش عمده اكمال تخصـص و ارتقاى ظرفيت فعاليت دارند. آمريت هاى اسـتخدام، ارتباط مأموران، سوانح و اصلاح و انكثاف اداره از بخش هاى ديخر رياست منابع بشـرى وزارت صحت عامه مى باشند. تعداد كار كنان وزارت صحست عامه درمركز و ولايات به به بـات 
كذشته سيستتم رقابت آزاد وجود نداشت و اكثراً استخدام ها براساس مناسبات انجام مى شد." كميسـيون مسـتقل اصلاحات ادارى و خدمات ملكـى به عنوان تســـيل كنتــده و ناظر از روند

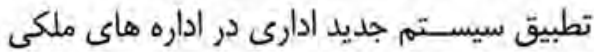
افغانسـتان ايفاى نقش مى كند. اين كميسـيون تلاش مى نمايد در بهبود وضعيت عرضه خدمات به مردم، اداره ها را يارى رسـاند. داكتر احسـان الله شـهير در مـورد نقش كميسـيون در بهبود وضعيت ادارى و عزضه خدمات در وزات صحت عامه به اين باور اسـتـ:" سيستم واحد ادارى در افغانستان توسط كميسيون اصلاحات ادارى طرح شد. اين سيسـتم قابل اجراء بوده و كميسيون از از

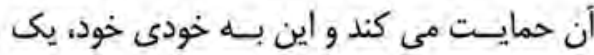

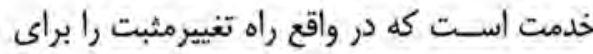
اداره هاى ملكى أفغانستان ايجاد كرده است. در

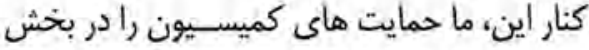
هاى تخنيكى و ارتقاى ظرفيت با خود داريم ـ.در

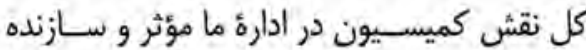

به كفته رييس منابع بشرى وزارت صحت عامه،

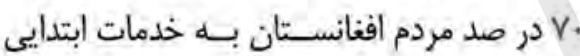
صحى مثل واكسـين و خدمات قبـل از ولادت دسترسى دارند. به كفته او قرار است يك شوراى حدماي طبى در افغانستان از سوى اين وزارت إيجاد كردد

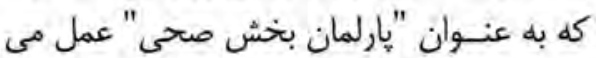
نمايد، و بخش صحى رادر افغانسـتان كنترول

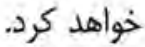

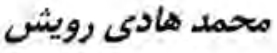

سـكتور خصوصى تأثير مسـتقيم بر بخش هاى

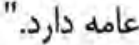
"سـميرا حكيميار" مدير ديتابيس اين وزارت مى كويد:"در وزارت صحث عامه از هـ سال بدين سو

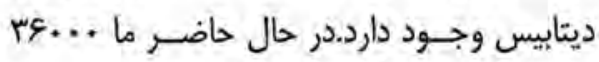

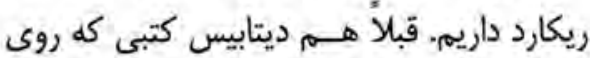

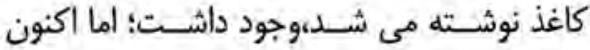
ديتابس كه به شـكل الكترونيكى إيجاد شده و

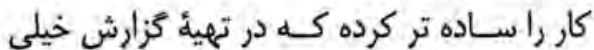
مهرم است." يكى از شــار هاى كميسـيون اصلاحات ادارى و خدمـات ملكى در جذب كاركنـان، رقابت آزاد

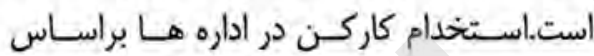

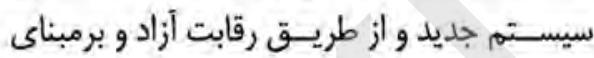
شايســتى انجام مى شود. اين كه رونداستخدام در وزارت صحست عامه جكونه صورت مى كيرد ، رييس منابع بشـرى وزارت صحـت عامه مى

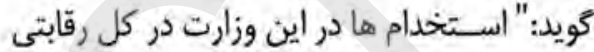
اسـت؛ اما وزارت صحت عامه به خند كتكورى كاركن اسـتخدام مى نمايد. يكى از روش ها در

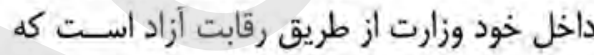

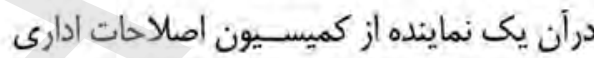
نيز حضــور دارد. بخش ديكر كاركنان متخصص اسـت كه در امور شـفاخانه ها و كلينيك ها كار مى كنند. اين دسته از كار كنان تو سط بوردى از متخصصين واز طريق رقابت أزاد اسـتخدام مى لـى شــوند. يكى از مشكلاتى كه وزارت صحت عامه با آن مواجه استـ، همين بخش مى باشد. مثلاً در بخش انجنيرى وسـايل طبـى، افراد كمى در اقغانستان وجود دارد." "عبدالحبيب رؤفى" آمر اسـتخدام رياست منابع بشـــى اين وزارت مى كويــد:" يكى از امتيازات سيسـتم جديد، اسـتخدام از طريــق رقابت آزاد

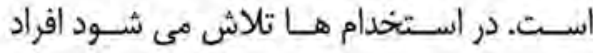
شايسـته و لايق استخدام شــوند؛ در حاليكه در
مى كردند ؛ اما در حال حاضر ما تلاش مى كنيه نياز مندى هاى خودمان را تشـخـيص بدهيم، و كاركنان مان را براى آموزش به بيرون از كثــور بفرستيه. فرصت هاى تحصيلى در خارج از كشور فرصت هاى طلايى براى ايجاد ظرفيت در اداره

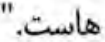
او درادامـهـ مى كويــد:" به ارتقــاى ظرفيت در بخـش هاى تخنيكى نيـز توجه جدى صورت كرفته است. در بورس هاى كشور هاى همسايه كه از طرف وزارت بيشــنهاد شده، در كل مربوط بخش هاى تخنيكى اسـت.أموزش اسـتفاده از

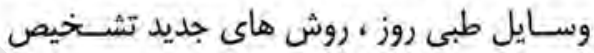
و تداوى ، بخــش هاى كلينيــ ( درمانغاه) از مواردى است كه در اين بورس ها براى كاركنان وزارت صحت عامه آموزش داده مى شود. برنامه ائه آموزش قابلغى نيز يكى از موارد مهمه ديخر است.

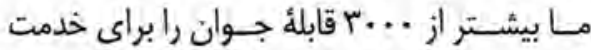
به دور دسـت ترين نقاط افغانسـتان فرستاديم و همينطور برنامهُ "نرسنگ" را كه از لحاظ اهميت

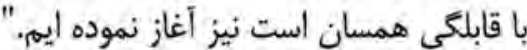

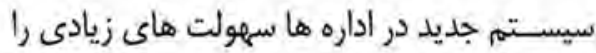
براى اداره هاى ملكى افغانسـتان به وجود آورده أست. يكى أز بخش هايى كه در سيستم جديد

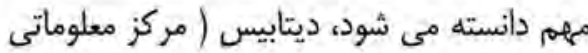
) استـ. بس از تطبيق بروسةُ اصلاحات در اذاره

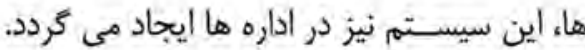
به كفته رييس منابع بشرى وزارت صحت عامه كار بــراى غنامندى ديثابيـس از جمله معلومات كيفـى هون دانسش كاركنان نيـز دراين وزارت جريان دارد.وى مى گويــد: " ديتابيس مى تواند

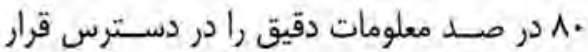

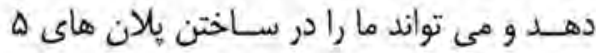

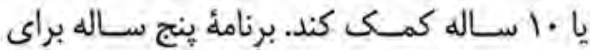
بخش عامه ترتيب شده و ما تلاش داريم بخش هاى خصوصى را نيـز در نظر بكيريه، جون كار 

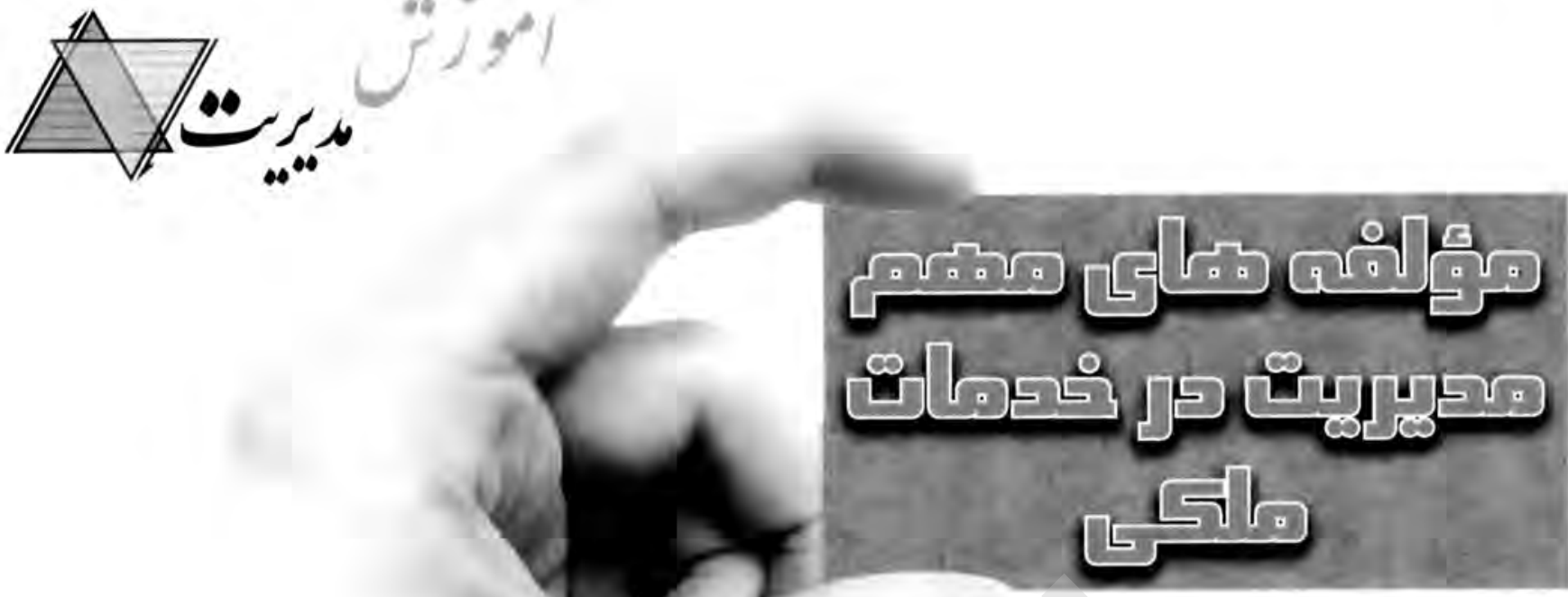

جاويد فرهاد

توسـعلة فعاليت هـاى درون سـازمانى و ترغيب كاركنان بــراى كار بهتر ومؤثر، از عملى شـــن

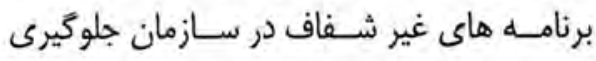

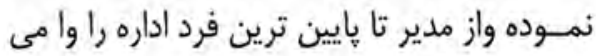
دارد كه الزاماً شـفاف عمل كنتد تا بقاى شان در فرايند كار و سازمان تضمين گردد.

\section{r- توجه به ابتكار و خلاقيت:} توجه به دو مفهـــوم "خلاقيت" و "ابتكار" در هر كارى - به ويزه در روند فعاليت هاى سـازمانى از مهمترين مؤلفه هاى ارزشى در اداره است. افغانسـتان كثــورى اسـت كه هـ إز سال ها

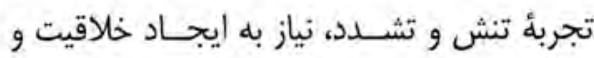
ابتكار و سيس توسعلة آن در همه زمينه ها دارد. نهاد هاى متعلق به خدمات ملكى در افغانسـتان نيز از شــمار سازمان هايى اند كه افزون بر انجام

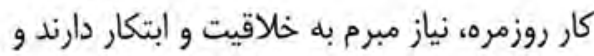
اين خلاقيت و ابتكار مى تواند از يك كار كوحى سازمانى تا كار بزرى در حوزه اداره (و يا سازمان)
ذهنيـت مثبت براى انجـام كار بهتر رادر وجود

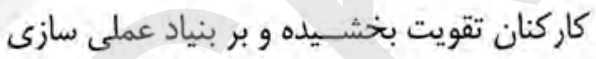
روش اصل شايسـتخى، از انجــام كار مثبت زير دستانش سـتايش كند و همواره انگيزه ى انجام كار بهتر رادر ميان سازمانش تقويت نمايد. "ييتر باخ" كه از دانشـمندان مطرح علمه مديريت

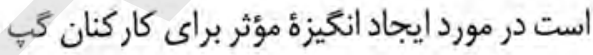
جالبى دارد كه اينجا نقل مى شود. باخ ميكويد:" ايجاد انگيزه براى كار بهتر، سبب ارتقاى ظرفيت

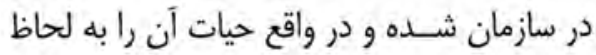

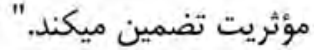
r - بافيت טر كار: هـر هيزى كه بر بنياد شـفافيت شـكل بكيرد، سـبب مى شود تا ديكران نيز از آن روش بيروى بـي

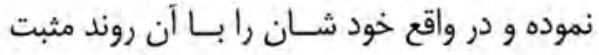

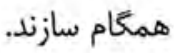
شـفافيت در سازمان و جلوكيرى از ابهام و توهمم و دورى از فسـاد در هر بُعـدى از كار، افزون بر
هر كثــورى - به ويثره كشورهاى جهان سـوم مانند افغانستان - نياز به خدمات ملكـى توانمنــد دارد؛ زيــرا توانمندى در عرضه خدمـات، جيزى اســ كه امروز شهروندان جوامع مختلف به آن ضرورت دارنـد؛ اما اين نياز همان سـان كه كَفته شد زمانى مى تواند بر آورده كَردد كه ما بتوانيم نهاد هاى متعلق به خدمات ملكى ني كارا و توانمند داشته باشيم.

مؤلفه هايى كه مى توانند به عنوان زير مجموعه

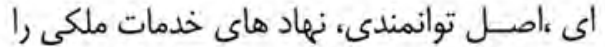
كارا، مفيد و اثر كذار بسازند به كونهُ زير است:

\section{| - ايجاد انكيز ه براى كار بهتر:} ايجاد انكيـزه در وجود كاركنــان خدمات ملكى تهـي يكى از روش هاى مديريت اثر كذار اسـت؛ اين روش مبتنى بر شـكل دادن ذهنيت مثبت براى كاركنان اسـت. مدير خوب كسى است كه بتواند 
مى تواند به وسـيلة ايجاد رابطــهـ ،كار مديريت

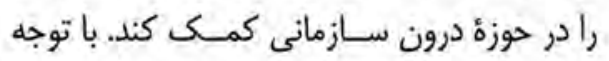
به آن خه كَفته شـــ ايجاد رابطة بيرون سازمانى درونى

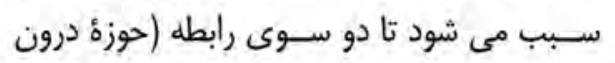
سازمانى و حوزة بيرون سازمانى) در فرايند ايجاد اين دو سـويكى ارتباط، بيشـتر از ييش تجارب،

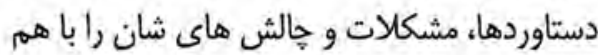
در ميان كذاشـته و ظرفيت هاى درون سازمانى در حوزة مديريت تقويت كردد.

\section{ج - تقويت ظرفيت هاى كاركردى:}

رشــــ و تقويت ظرفيت هاى كاركردى، از عوامل

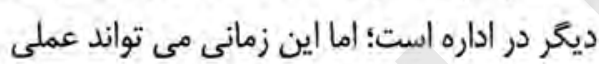
شود كه مدير در حوزة كارى نخست از همه أين ظرفيت ها رادر وجود كاركنان شناسايى نموده و سيس آن ها را تقويت كند.

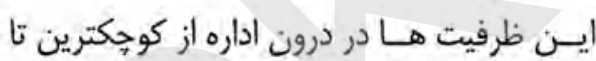
بزركترريسـن كار كـرد راد بر بر مى كيرد كه مدير

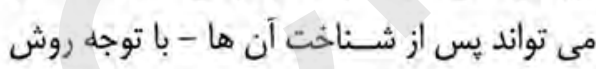

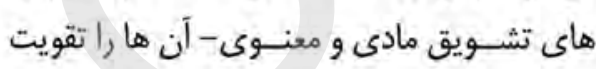
كند.

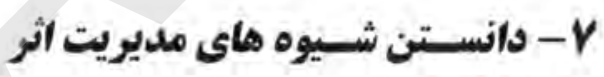 كنار:}

افـزون بر ايـن كــهـ تجربـهـه در روش مديريت

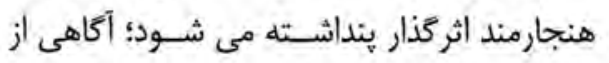

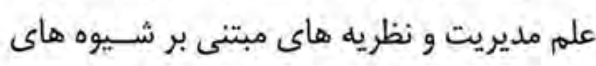

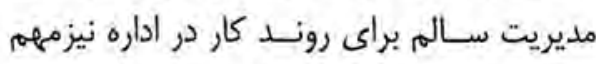
اســ؛ زيرا داشـتن تجربئ جمع دانستن نظريه

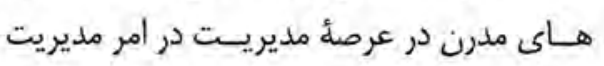

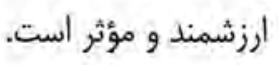

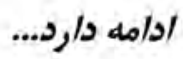

أغاز مى شود؛ اما جيزى كه در فرايند توسعلٌ اين دو (خلاقييت و ابتكار سازمانى) مهم است، ارزش كذاشـتن و ارجح دانسـتن اين خلاقيت و ابتكار

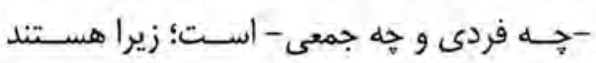
مديرانى كه يـا از روى خود برتربينى و يا ازفرط ترس از دسـت دادن به تعبير خود شان "كرسى و "مقام" به هيج گونه خلاقيت و ابتكار سازمانى افراد ارزش نمسى كذارند و يا هم انجام هر گونه

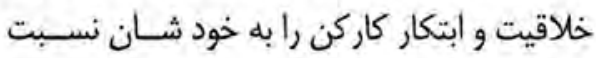
ميدهند. از نغاه آسـيب شناسـانه اين عملكرد سبب مى مي شــود تا كاركن از خلاقيت و يا ابتكارى كه انجام داده دلسـرد شود و سطح ميزان كار آيى آميخته با ابتكاردراداره نيز يايين بيايد.

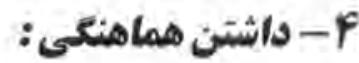

موجوديت هماهنكى در سازمان (به ويثه در نهاد هراى متعلق به خدمات ملكى در افغانسـتان) از

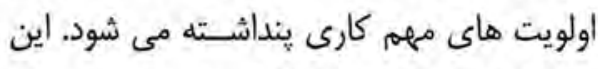
هماهنكى مى توانسـ از رابطه هاى نزديك ميان مدير و كاركن و هم هنان كاركن با كاركن ايجاد

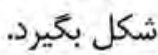
مشــوره و نظر دهى فــردى و جمعى براى بهبود

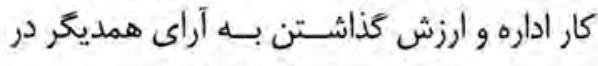

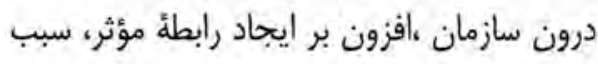

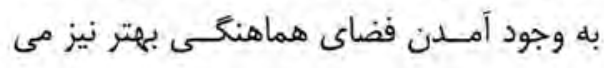
شود.

\section{هـ - رابطله دو سويه (درون سازمانى با بيوون سازمانى)}

ايجـاد رابطة درون سـازمانى با عوامـل بيرون

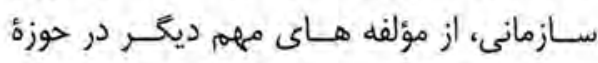

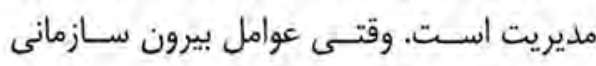

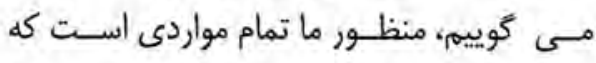



اها اين غيـــــ از متعلق بودن بــه هويت ملى

شان.

با توجه به اين كه دانشـمندان معتقدند كه "اين

زمان. بيشـتر زمان جنى روانى است تا نظامى" لونى (T)، جنگ هاى روانى گسترده يى در سراسر دنيا براي بى باورى و بى هويت سـاختن شهروندان كشور هاى مختلف جريان دارد. يكى از دانشــمندان علم ارثباطات مى كويل: "در جنك روانى بيشـتر از اين كـهـه آدم ها را تحت تسـلط بكيرند، بيشتر از همه فكر آن ها را اشغال

مى كنتد." (ז)

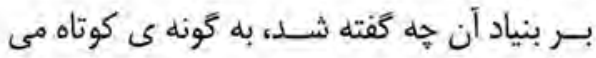
توان كفت كه جنگ روانى در واقع، ستيز با افكار، اعتقادات و انديشه هاى مردم است. 1- انغاره سازى: 9- انغاره سازى از روش هاى مهم ديكر در فرآيند سياستخذارى در خبر اســت. مثلن در انغاره سازى، نام "صدام حسـين" در كنار "أدولف هتلر" برده مي شــود؛ زيرا تصور مخاطب در حر

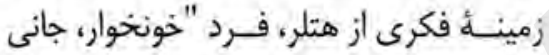

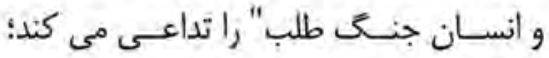

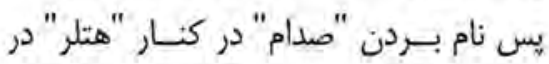
خبـر ( و يا كونه هاى ديكر اطلاع رسـانى) ديخر ضرورتى به تشبيه و تفسير ندارد و اين مى شود انغاره سازى در خبر كه امروز يكى بـ له

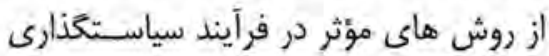

$$
\text { رسانه بيى دانسته مى شود. }
$$

يانوشت:

1- يايـعاه انترنتسى بسى بـى سـى، صفحسه

اقغانستان.

r- جورج ويلز، ارتباطات جيست؟ ترجمه دكتر فرنود بهراميان، انتشـارات سلسبيل، ايران، جورئ

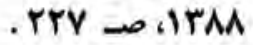
ץ- مديريت در خبر، دكتر محمد تقى روغنى ها، نشر نقره، ايران، IrAF
القاى بيام خودش جا مى أفتد. r- به كار گيرى روش مبالغه به گونه و كاهى هم غير مستقيم.

f- اسـتفاده از اشــاره و كنايه مثلن: به كفته كارشناسان و آكاهان. ه- اعلام اخبار و اطلاعات نادرست و كشف آن توسـط رسـائه ها (به كّونه ى مثال حنج خبر دروغ از جانب يك خبر خزارى ارائه مى شود، بعد از جمع آن ينج خبر، يكى را كه متوجه مى بى شــوند رد مى كنند؛ اما در مورد جارتأى ديكر جون آكاهى مشـخص وجود ندارد، آن جهيار خبر كـــب به صورت غير مسـتقيم تأثيرات خود را در افكار عامه باقى مى كذارند).

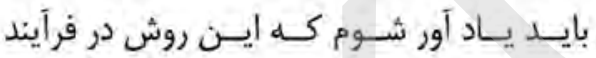

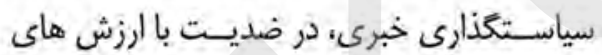
خبرى و در كليت رسـانه يى قرار داردو از شمار ويره كى هاى مثبت شـمرده نمى شـــود؛ اما اين كونه روش در زمينه ى إيجادسياستخذارى براى سـمت دهى افكار عامه وجود دارد و بسـيارى از رسانه هايى كه به كونه يى فضا سازى مى كنند، از اين كونه روش بسيار استفاده مى ثمايند. 9- تبليغ: هدف تبليغ در كليت آن است تا ديدكاه مردم را عوض كنــد اين تبليغ هم مى تواند در جهـت مثبت صورت كيرد و همم در جهت منفى. در خبر هم تبليغ به كونه ى هدفمند و با توجه به مشـى و سياست رسانه يى عملى مى شود. V- جنگ روانى: جنى روانى يكى از روش هاى ستيز بيشتر به خاطر از دست دادن باور انسان ها استـت يعنى در مرحلـهـ ى جنى روانى، آنقدر باور مردم يك كشور از لحاظ فرهنگى و ملى مورد أماج و تمباجسم قرار مى كيرد و كوبيده مى شود كه مي خواهند هر حهه باشند:
اطلاعات خبرى به منظور رسانش ييام در سرخط خبر ها، جيكونه شكل مي كيرد.

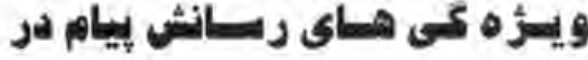
1- خبر بايد جذاب باشد و حتا شكفتى أور؛ r- همسويى ايجاد كند؛ يعنى همسو و در جهت منافع ييام كيرنده (مخاطب) باشد؛ r- بيام خبرى جنبه هاى انكيزش و ارخا داشته باشـــ (يعنى ســبب إيجاد انغيزه و ارضا در وجود فرد شود)

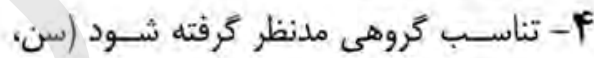
شغل و دانستن ذوق مخاطب بسيار ضرورى

هـ- رعايــت اصل انصـاف، اعتــال، احترام به مخاطـب، جدا كـردن ديدكاه شـخصى از واقعيـت هــا، مؤثق بودن، صحست و دقت، يرهيز از تهمت، امانت دارى و توجه به ذايقه ى مخاطب، از ويثُه كى هاى مهمر رسـانش يبام در خبر است.

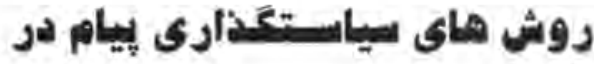
\%

1- تــلاش بــراى ســر در خُم كـردن مخاطب

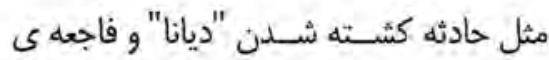
دو بــرج آسـمانخراش در نيويارى كه بحث ميث

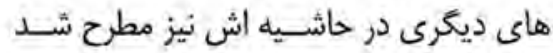
تا موضوع اصلـى آن ها ينهان بماند. در اين فرآيند با نشـر اطلاعات كوناگون در اين دو لون مـورد، ذهن مخاطـب به منظور سـر درگم شدن، بمباران خبرى مى شود.

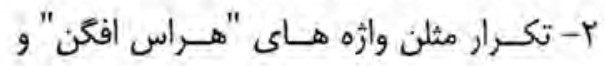

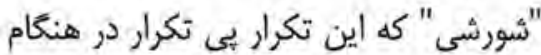



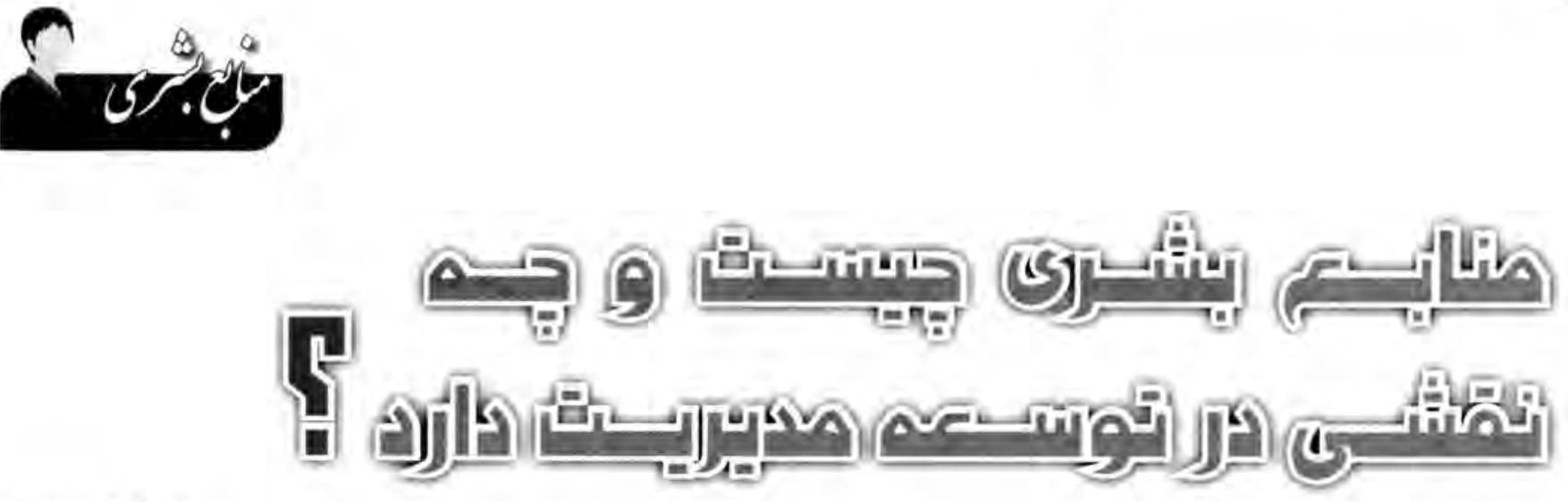

عليرضا / عيزد يور

واتســون )از صاحب نظران مديـر يت ميكويد:

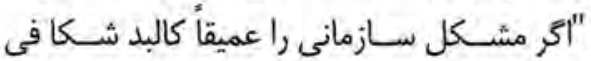
كنيـــ، در نهايت خواهيد ديد مشــكل ريشـــه در رفتار هاى منابع انسانى دارد" . در جهـان امروز نيروى انسـانى جايكاه خاص و ويـزة كى هايـى را به خود اختصـاص مى دهد

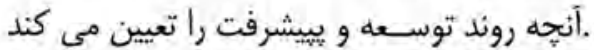
نه سـرمايه،منابع مادى و تجهيزات؛ بلكه نيروى

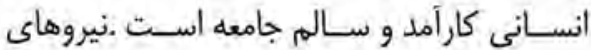

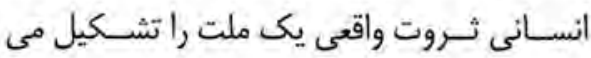
دهند .هر تلاشى در راستاى توسعه بايد به انسان و تربيت ويرورش او به صورت خاص توجه نمايد .راهبرد منابع انسـانى در كشورهاى توسعه يافته

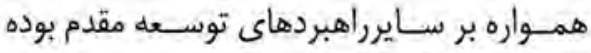

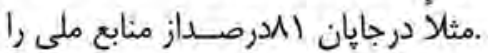

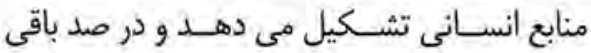
مانده مشــمول منابع طبيغى و فيزيكى مى شود و نكتــــ قابل توجه ايـن كه در منابع مادى و فيز يكى محدوديت وجود دارد؛ ولى منابع بشـرى به به منه عنــوان مهمترين منبع، مدت زيــادى مى تواند

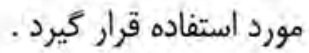

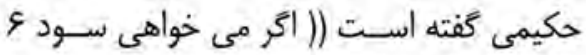

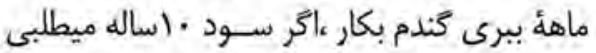
درخت بكار و اكر طالب سود بيشتر وبهتر هستى بهارت كه ...اسال سود دهد ،انسان تربيت كن )|| .
اتـــر ما بتوانيم انسـان و نيازهاى او را به

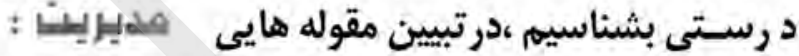

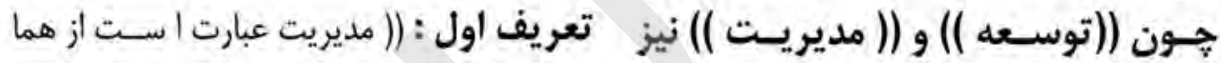
هiّى كردن منا بع انسا نى ومادي براى نيل به هدف سازمان ).

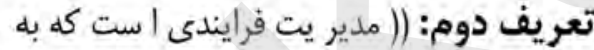

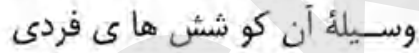
وكروهى بـه منظور نيل به هدف

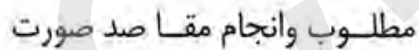

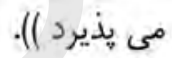
تعريف سوم: (( مديريـت هنــر انجــام دادن كاربه وسـيله و ازطريق ديخران

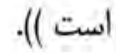

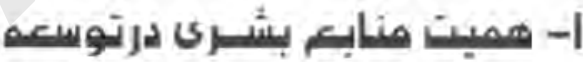
صدمبر ليقات:

د رميان عوامل متعدد درمديريت، (( منابع بشرى

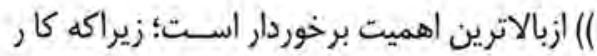

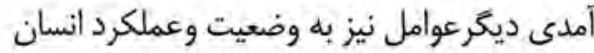
و رفتارهاى او مرتبط است وبرهمين مبناست كه در بازكشت (( سرمايه )) به عنوان يكى ازبارزي ترين شـاخص هاى بهره ورى سازمان ،مرهون

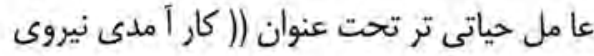
انسانى )| است. اهميــت ايـن نكته تا آن جايى اسـت كه (( جى اسئ : نे توسـعه عبارت است أز (( بهينه سازى در استفاده مؤفـق خواهيم بــود. .يس اصـل مهرم و اساسى اين اسـت كه انسان و نيازهاي او در جامعسه مد نظر قــرار تيردذلذا قبل از اينكه وارد عرصة اصلى بحث شــويم، مدئ ضـرورى اسـت تعاريفـى ازدو اصطلاح

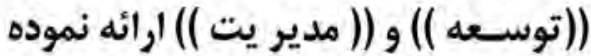

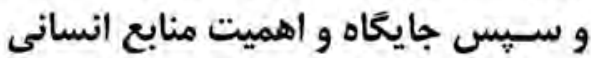
• الشريح نما ييم

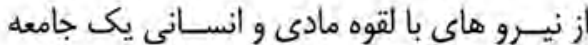

در روند توسعة اجتماعى ، اقتصادى و فرهنكى هر

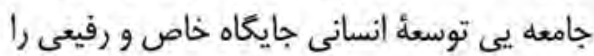
بـهـ خود اختصاص مى دهد و به طور خلاصه اكر جامعه يى بخواهد به مفهوم كلى توسـعه دست يابد ، ضرورى اسـت هفت اصل ثابت توسعه كه له اكثر صاحب نظران بر آن اتفاق نظر دارند رامورد توجه قراردهد: 1-هيأت حاكمه ب- توجه به علم r- نظم f- آرا مسش اجتماعى ه- نظام قانونى 9- نظام آموزشى V- فرهنى اقتصادى . 
دانشمندان و فن ورزان با برنامه ريزى اقتصادى

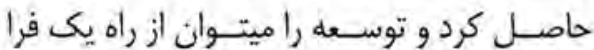
كرد رشــــــه در بركيرندة تربيت ،سازمان و نظمه

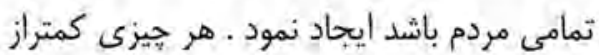
اين به شكست مى انجامد .

منابع مورد استفاده : 1 - سـريع القلم، محمود - توسعه ،جهان سوم

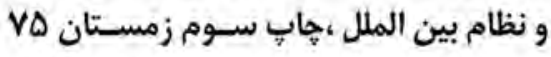
- نشر سفيد.

r-سريع القلم ، محمود - عقل و توسعه يافتكى سيد

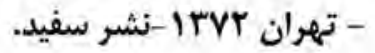
r- حاج يو سفى ، على - توسعه و رفاه اجتماعى

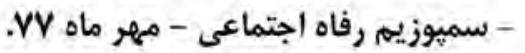
F - حسينى ، اسـحاق - محوريست انسـان در توسعه.

ه- سـرمدى ، محمد رضا -مديريت اسلامى - توسعه - نداء انتشارات دانشخاه بيام نور.

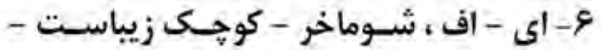
ترجمهُ على رامين - انتشارات سروش.
و اجتمــا عى مردم و مطالعـه و يخه كى هاى هر يك از اين عنا صر و تلفيق مطلوب مجموعه اين عوامـل باتأكيد بر منابع انسـانى و تطبيق آن با

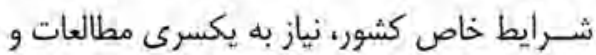
تحقيقات دارد .كه در اين رابطه شناخت و تحليل

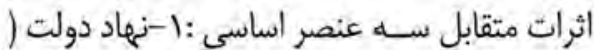
هيـأت حاكمه ) r-نزبادها ى اقتصادى و توليدى

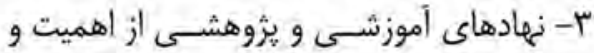

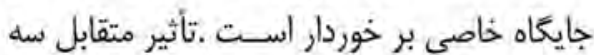

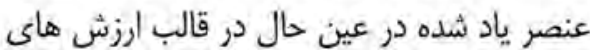

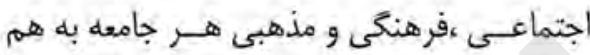

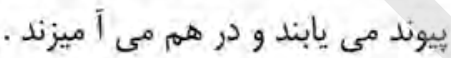
نمادة افتمادي و تواليدى: بـه طور كلـى و در نتيجه مى تــوان هنين بيان

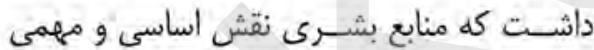

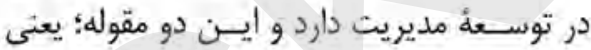
انسـان و مدير يت بـرزروى يكديكر تأثير متقا بل مديل

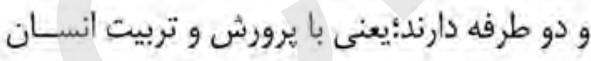

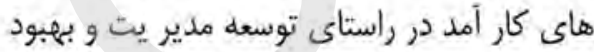
وضع مدير يت هاى سـازمان كام بر ميداريهم و از مداز

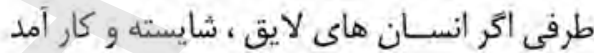
مدير يت جامعه و سـازمان ها را به عهله كيرند، در تربيث و يرورش ند جامد نيروى انسـانى وتوجه به منابع انسانى به عنوان مهمتر ين عامل در توسعه توجه خواهند نمود .

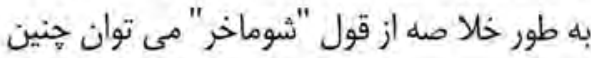
بيان داشت : (توسعه با كالا هاى مادى آغاز نمى آنى

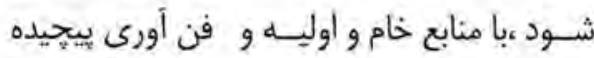

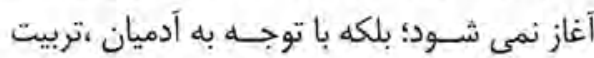

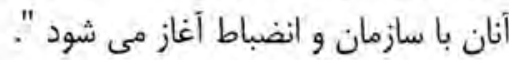

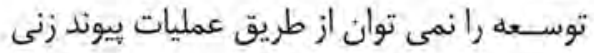

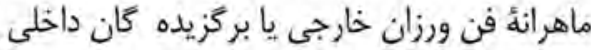
كه تمـاس خود را با مردم عادى از دسـت دارجت داده اند توليد كرد ـ توسـعه را نمى توان از راه معجزة
در همه كثورهاى جمان أموزش وتربيت نيروى انسـائى به عنوان مهمترين سـتراتيثلى توسـعل فرهنگى و اجتماعى و اقتصادى تلقى مى شـــود

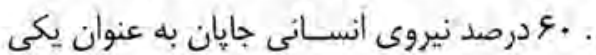

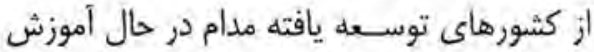
اند ـ أموزش و يرورش نيروى انسـانى، مهمثرين

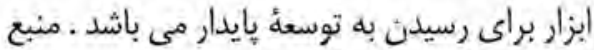
اصلى نـو فكر كردن و خلاق بودن به سيسـتم آموزشـى و يثروهشى بستكى دارد .انديشه جديد،

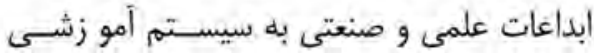
منظم و يويا ارتباط دارد .

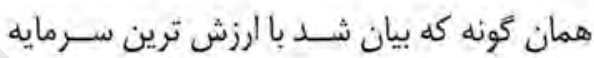

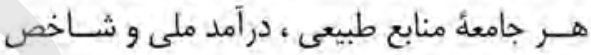

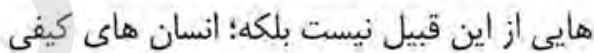
با تحصيلات ، فرهثـ و هنرواز همه مهمتر با نيا

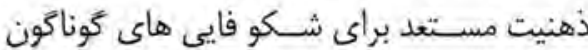

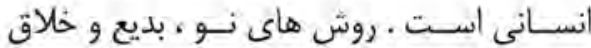

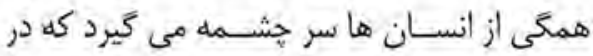
نظام أموزشسى يويا و كار آمــد و به طور كلى در هم

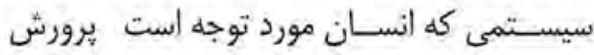

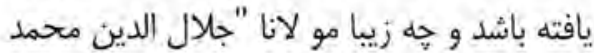

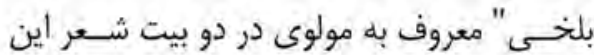

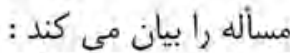
(( باده در جوشـش كداب جوش ماست ماست جــرخ در تردش اسـير هوش ماسـت

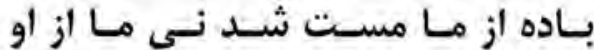

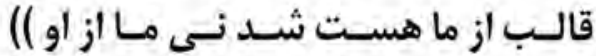

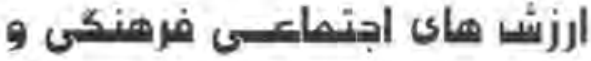 : vidiata} أرى در راستأى تحقق يك برنامه ريزى كلى در كثــور و توسـعله مدير يت بله مفهوم وسيع كلمه بروسـى امـور اقتصادى و شــرايط جغرافيايى و طبيعى ، مواد اوليه،سرما يه ، نيروى انسانى و بإيه

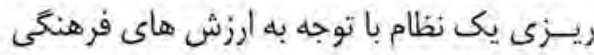




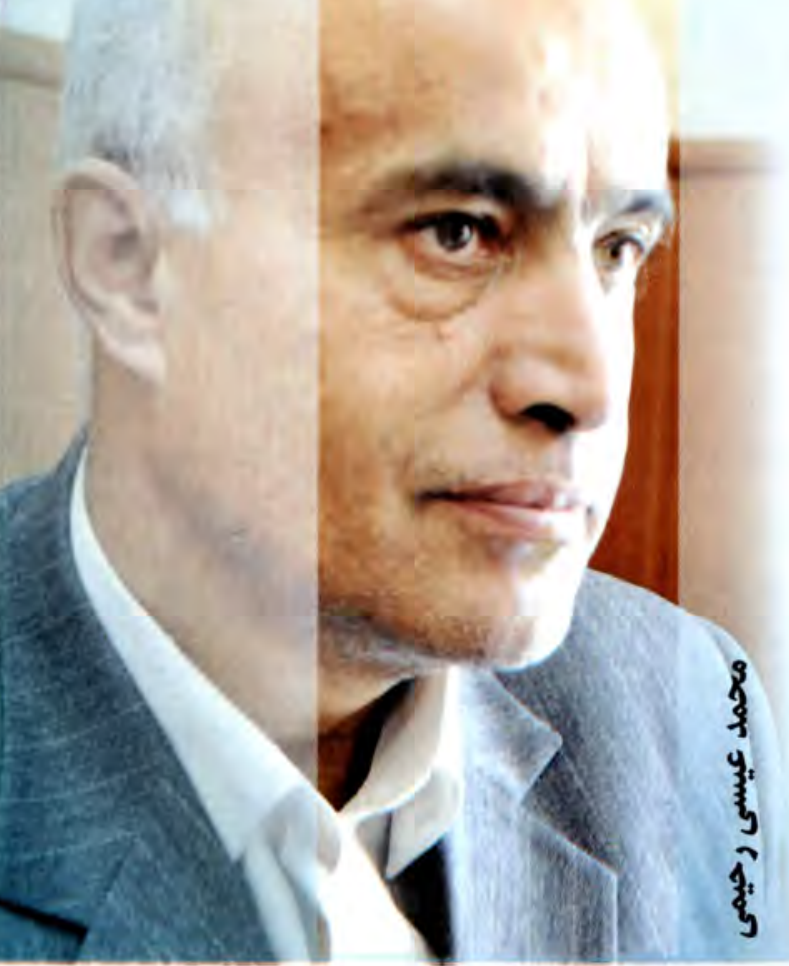

\section{نياز مندى هاى مبرم}

جامعهُ افغانى ودلايل

احياى مجدد كوير اتيف

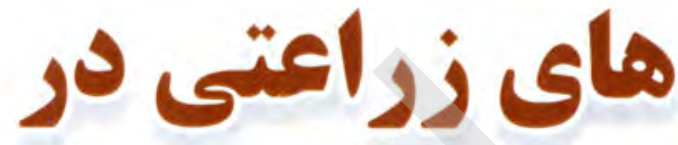

افغانستان

وجلو گيرى از فقر در حال توسـعه در كشور هاى جنى زده وفير ندير

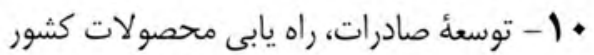
هاى فقير و ناشـناخته به بازار هاى بزرى بين المللـى كه متضمن ثبــات اقتصادى كشور ميزبان كويراتيف مى كردد؛ | | - زمينه سازى براى تحقيق علمى، به منظور انكشاف اقتصادى وخود كفايى افغانستان؛ r إيجاد فرصت ها براى جلو كيرى از ضايع شـدن محصولات زراعتـى وبعبود حفظ الصحئ محيطى ؛

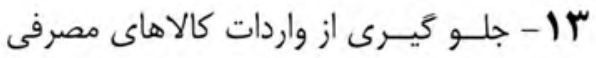
- به خصوص مواد غذايى وخروج اسـعار

$$
\text { معتبر -از كشور؛ }
$$

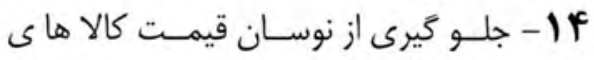

مصرفى به خصوص مواد غذايى؛

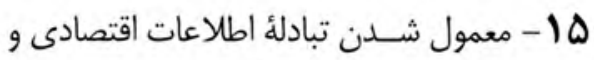
فراهم شدن فرصت ها براى تحكيه ثبات
ب- كاهشُ مصـارف آب در مناطق داراى اقليم

خشـى وتأمين فرصست هاى بهتـر براى

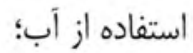
f - ترويج ميكا نيزه شـــن زراعـت وبالا بردن كيفيـت محصولات زراعتى در يك كشــور

$$
\text { جنى زده مانند افغانستان؛ }
$$

ه- ايجاد اشـتغال ل وييشــه هاى متــداوم براى جوانان بيكار، كاهش سطح بيكارى به حيث

$$
\text { عامل اصلى جنگ در افغانستان؛ }
$$
و- ايجاد فضاى باور واعتماد بانكى براى دريافت قرضه هاى مالى وبه دوران كذاشتن دارايى

$$
\text { مالى دهقانان ؛ }
$$

- V ايجاد بازارهاى با اعتبار براى خريد وفروش محصولات زراعتى درسراسر كشور ومنطقه؛

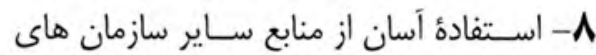
اقتصادى از طريق تبادله اموال وكالاها؛

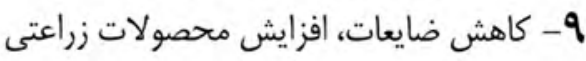

كويراتيـف اتحاد كَروڤ ها و مؤسسـات مسـتقل اقتصـادى اسـت كه بــه خاطر حصول منافع و رعايت اصول قبول شده در مسير معين، انكشاف يايدار را تعقيب و تا سرحد خود كفايى تروسه ها را مانند يك شر كت سهرامى ادامه مى دهند. ييوسـت به نظريـات رييـس جمهوراسـلامى

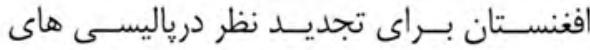
اقتصادى كشـور، با توضيح يك سلسله معلومات ضرورى، دلايـل احياى مجــد كويراتيف هاى زراعتى در افغانستان مورد بررسى قرار گرفته كه خلاصه آن ذيلاً جنين است: ا - تأميـن نياز هاى زراعتـى زارعان وباغداران درسراسر كشـور به قيمت ارزان وباكيفيت تضمين شده؛ r- ايجاد تسهيلات وفرصت هاى مناسب براى تأمين خدمات زراعتى به زارعان كم در آمد 
محصولات كــــان بهاى زراعتى ميوه هاى

فصلى افغانستان ضايع مى شوند.

اين بود فشــردة نتايج مختصــر طرحى كه براى سهم كيرى در بازسـازى افغانستان با استفاده از فرصت هاى مسـاعد شدة شــرايط كنونى كشور بــهـ منظور اتخاذ تصاميم ملـى بـه اطلاع مقامات دولتى و جامعه افغانى رسانيده شد.
به اسـناد قانونى صلاحيت استفاده ازقرضه هارا براى زرع و آبيارى ييدا كرده نتوانسـته لهانه

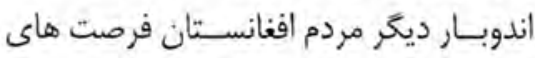

خوب را از دستـ داده و بار مسؤوليت هاى جامعلُ جهانى براى حمايت مالى افغانسـتان به جايش باقى خواهد ماند.

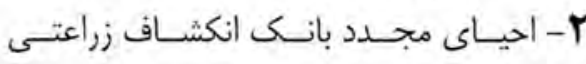
افغانستان و انكشاف شبكه هاى آن تاسطح ولسوالى هاى كشور به منظورعرضه خدمات بانكدارى و اعطاى قرضه ها باربح محدود .

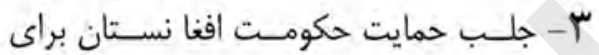
تجديــد نظــر در قاليسـى هايسش در امور اقتصادى ازجمله كوير اتيف ها غرض ايجاد

سريع وبا كيفيت خدمات درسطح كشور.

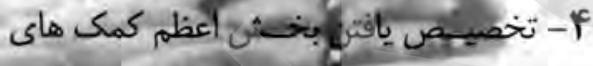

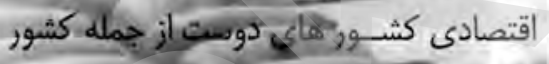

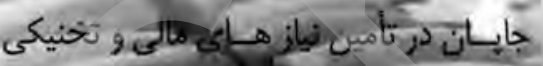

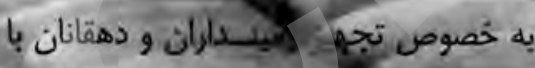
ماشين ألان بيشر فتله زراعتى، و سبهم كيرى در انكشـاف شــبكه هاى آبيارى مر سراسر

كثور.

هـ - مساعدسـاختن فرصت هاي آموزشى براى

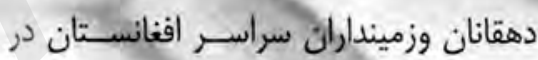
خار جوب خاليسـى عادلانه يى كه متضمن

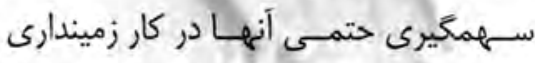
عصرى وهمكارى با كويراتيف هاى نو بنياد كشورشده بتواند. צ- همكارى با دولت افغانسـتان در امر سـهيم شدن اين كشــور در بازار هاى بزرى جهان غرض عرضــه محصولات زراعتى - به ويثه ميوه هاى فصلى اين كشــور - كه هميشـــهـ بنابر رقابت هاى ناسـالم و ســوء اسـتفاده كثــور هاى همسايه از بحران هاى موجود،

$$
\text { اقتصادى در كشور: }
$$

ع أ- أستفادة منطقـى از منابع داخلـى براى انكشاف اقتصادى كشور؛

لـايت سـفارش هـاى سـازمان غذايى - IV

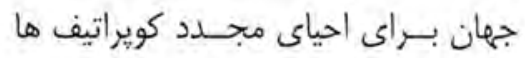
درافغانسـتان (بـهـ منظور خود كفاشــن افغانســتان واسـتفاده از منابـع موجودآن سـازمان) براى نجات حيات مردم كشــور هاى فقير جهان: 11- اســفاده از تجارب ملى افغانستان براى از

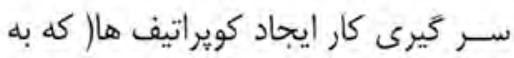
يقين كامل اسـتفاده از اين وسـيلة خوب براى انســام دهقانان به خاطر بالا بردن

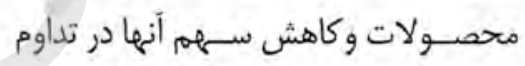
جنكهاى داخلى نيز مفيد خواهد بود.)

براى ايجـاد كويراتيف هـاى زراعتى در افغانسـتان از كــدام وســايل وامكانات استفاده خوب نموده مى توانيم؟ با ارايه جواب به اين سؤال، ميتوان بخش بزركى از بار مشـكلات كشــور و جامعل جهانسى رادر افغانستان كم نموده و فرصت هاى مناسب رانيز براى تأمين صلح يايدار در اين كشور جستجوكرد. به اين منظور مى توان بخشـى از اين وسـايل و امكانات را برشمرده و به معرفى كرفت: 1- جلـب حمايت حكومــت افغا نسـتان براى تجديد نمودن اسناد ملكيت زمين به عنوان يك اوليت مهرهم اقتصادى؛ زيــرادر ينجاه سـال اخير زمين به شـكل عرفـى و بدون موجديت اسـناد قانونى بين وارثين خانواده ها تقسـيم ويا اينكه توســ اســاد عرفى ئى

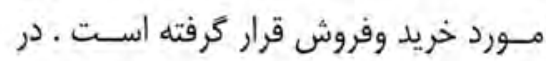
جنين حالت مالكين موجود بدون دسترسـى 


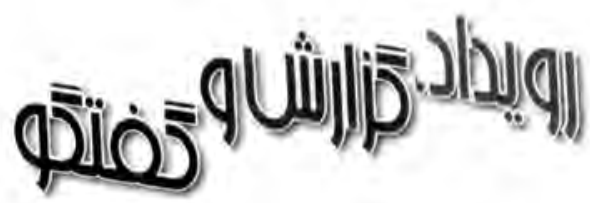

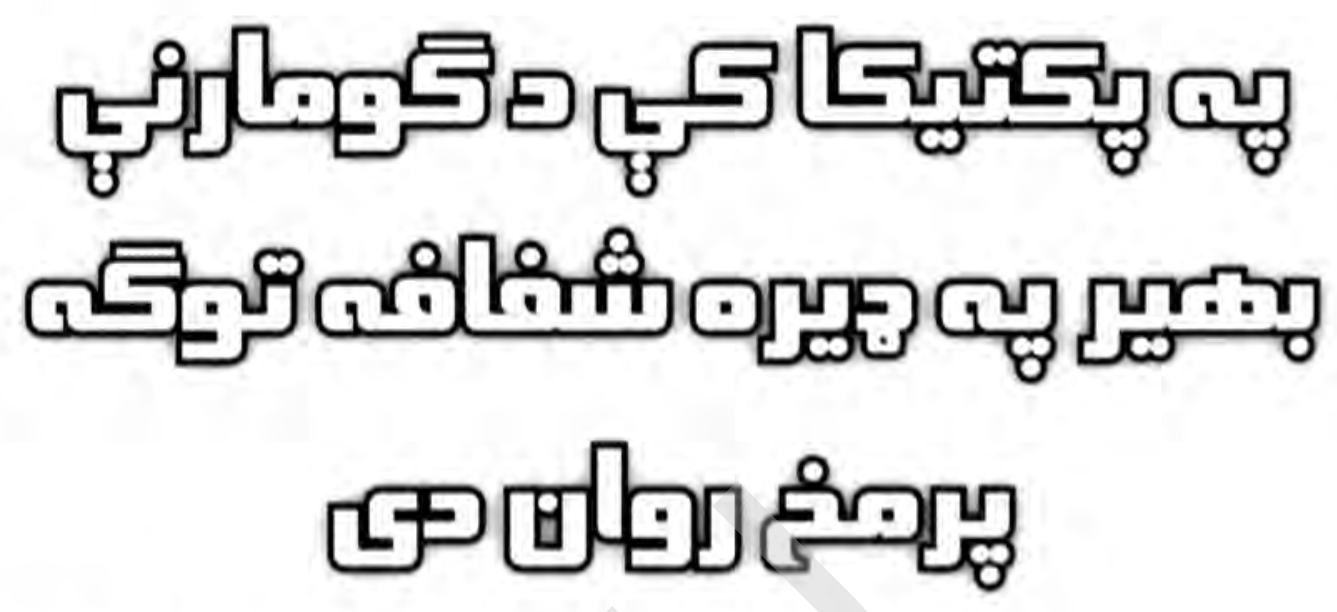

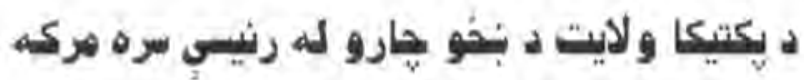

جـارو رياسـتـتــــــاد

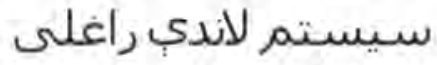

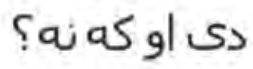

خواب: د دعاش او رتبو نوى سيستم زنا

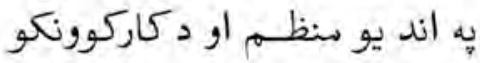

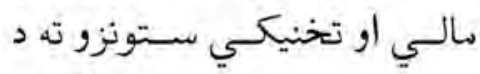

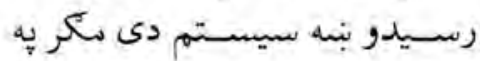

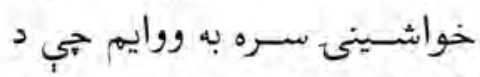

بكتيكا دبنسئو هارو رياستست لـ له

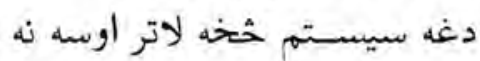

دى برخمن شـوى نـو لـونوبر هيله

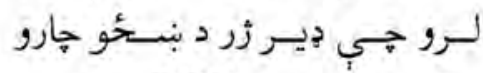

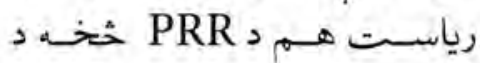

رتبــو او معــاش نوى سيسـتم ته

$$
\text { وليردول شي. }
$$

يونبثنه : يهيكتيكاكب دكومارنب بهير خنكـــه برمخ روان

נئ
د يادي كميتي له نورو غرو سـره

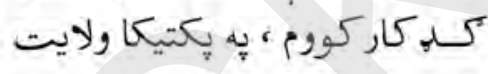

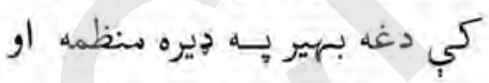

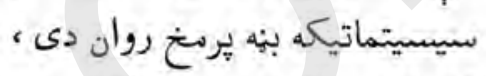

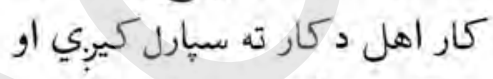
هركس د آزادو سـياليو له لاري

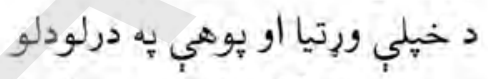

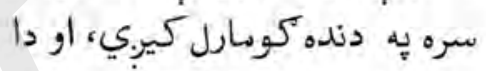
ويازر د اداري اصلاحاتو او ملكي ليكي خدنونو د خيلوالى كميسـيون دى نو خكلـه د اداري اصلاحساتو او ملكـي خدمتونسو خيلـوآ

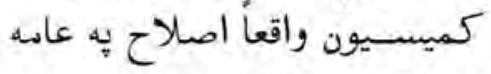

$$
\text { ادروكي نهن ته راوري ده. }
$$

يوبنتشه : د معــاش او رتبـو نـوى سـيســتمر خَنكه

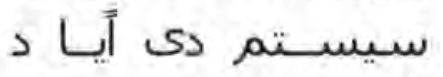
يكتيــكا ولايت د نبـــــو
يكتيـكا د هيواد د نالمنو ولايتو خخه هغه ولايت دى جـي د عامه اداري د اصلآح بهير يه جير بنــه او بريالس بنه يكي روان دى او به ملكي اداروكي د كاروريسان د دمونارنسي دكميتي لـه لاري يه ديندو

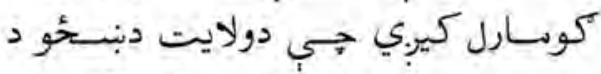
خارو د رياست به دوراني توكه د كتونكو يه توكه دنده تر سـره كوي دا هي يكتيكا

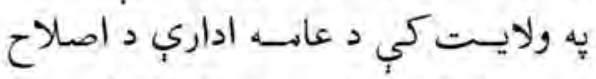

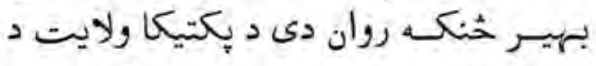
بنبحو هارو رياسـت له مشري آغلي بي

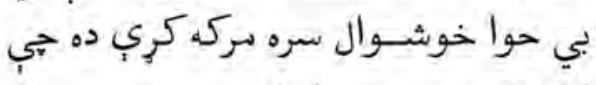
لوستلو ته مو بي رابولو:

يوسِتص : يه يكتيكاكي دكومارنب

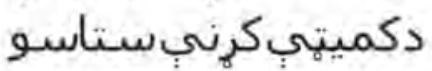

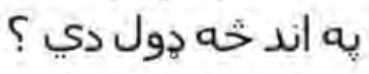

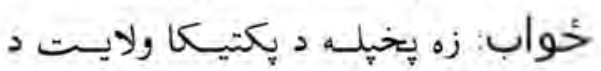

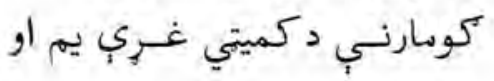


لانسه كيدو يه موخه خه

دي لاب

حُواب: زمــا ورانديـز د عانـه اداري د

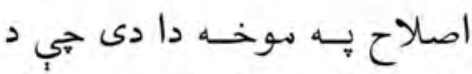

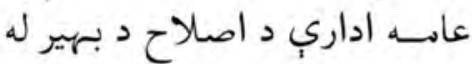
يوهاوي خثخه وركشايونه يه لاره واحول شي؛ تر خو تول كاركونكي

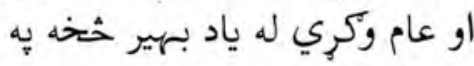
بنه دول سـره خبرتياومودي او د تولو كاركونكو خخه توليوبنـتنه وشي او د هغه لياره لازم كورسونه

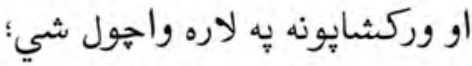
تـر خو دوئ د عادـه يوهاوي او همداشان د ورتياوو يه لورولوكي دي دواني يو مشبت بدلون راشي.

احمد فواد هــــــدايت
جيـرى كاركوونكي د عامه اداري د اصـلاح حثخسه يوهـاوى لري؛

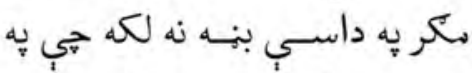
واقعيــت كي اصلاحسـات دي يه

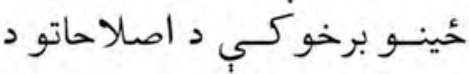

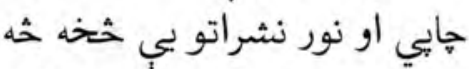
يوهاوي ترلاسه كري دى منكر كه

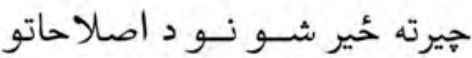

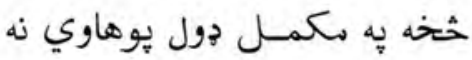

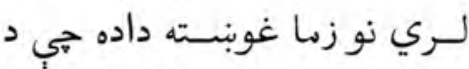
عادــه اداري د اصــلاح خه موخه وركشـايونه داير شـي؛ تر خُ يه بشـيره توكى كاركوونكي له ياد بهير خخه خبرتيا يِيدآري.

يونبـنه: سـتاســـو ورانديزونـهد عام a اداري د اص لاح د
حَواب: يـه يكتيكاكس دَكومارني بهير

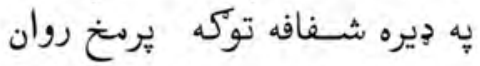
دى اوكار اهـل دكار ته ســارل كي.ي هغه كسيـان خي ورتيا لري يه آزادو سـياليوكي بدون دكوم هي

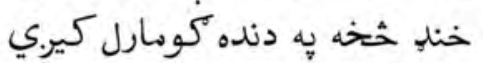
ياني كــوم زبنيز، قومي ، مذهبي او داسـي نور تعصبونه شتون نه

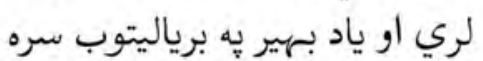
ير نخ روان دي.

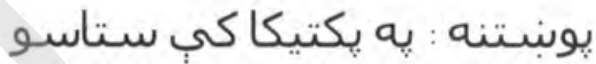
له نظـره خلـك د عامه ادارب د اصـلاح لـهـ بهير خخـــ خومــره يوهاوي

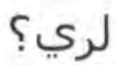
خواب: تر ديره بريده خي زه مالومات لرم 


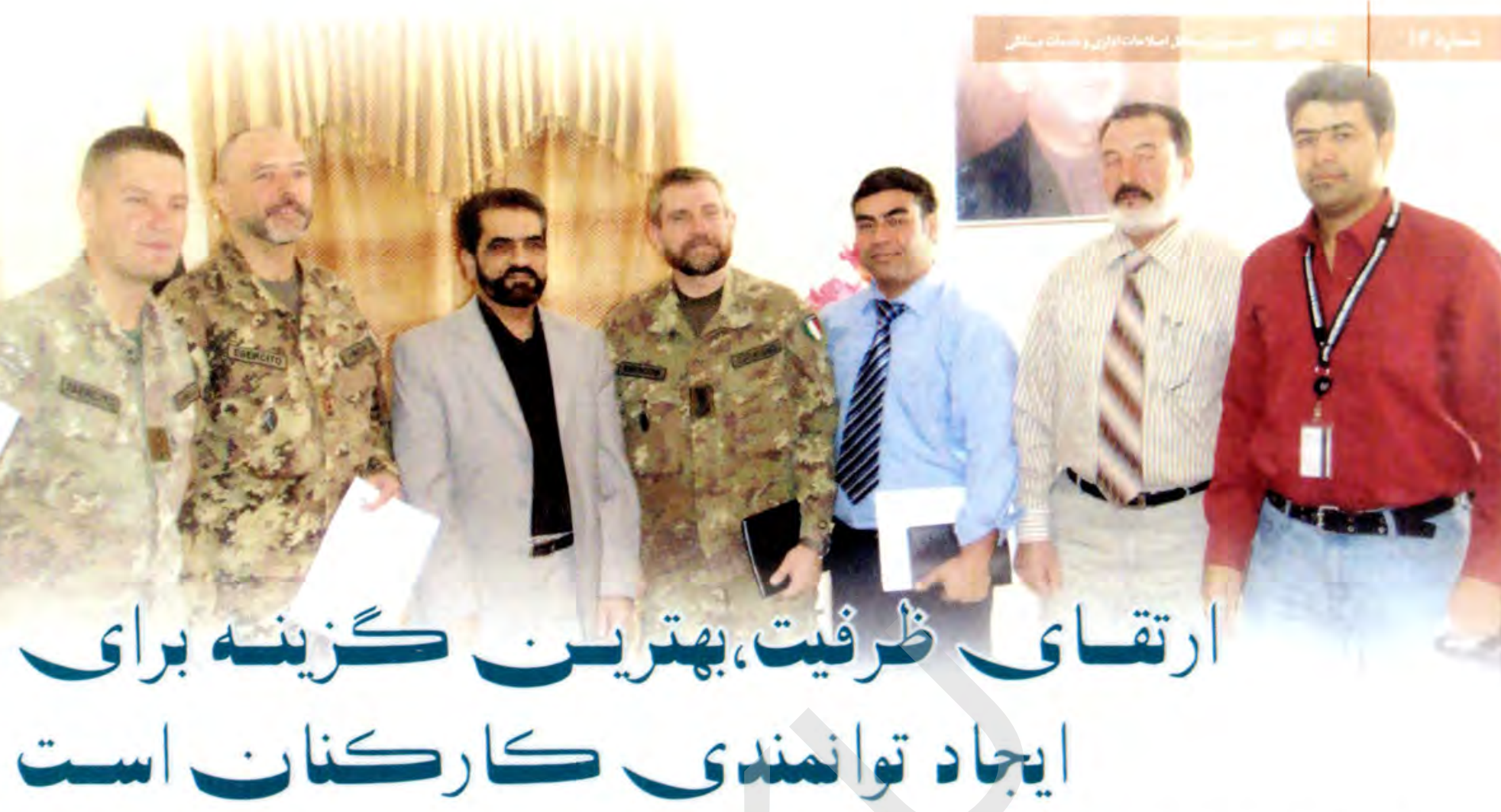

مركز و قدردانى از همــكارى هاى كروه" بـى آر "ايسن اداره حاضر اسـت تا براسـاس توافقى كه

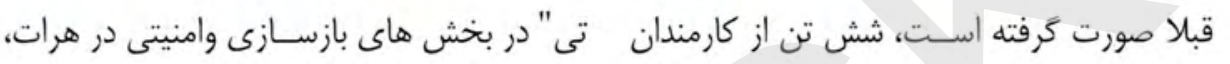

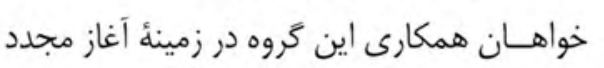

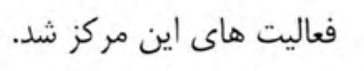

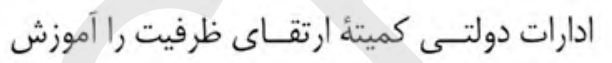

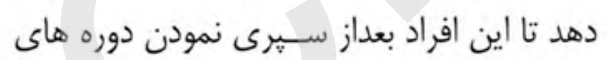
كميتــه ولايتـى ارتقــاى ظرفيـت، برانسـجام

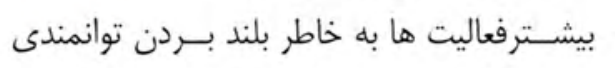

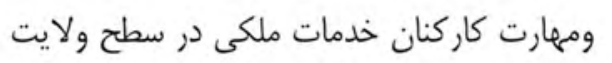

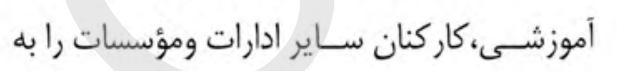
هرات تأكيد نمود.

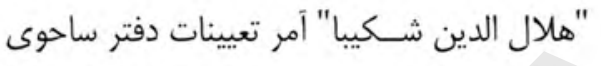
تطبيق اصلاح ادارٔ محلى زون غرب نيز كَفت:"

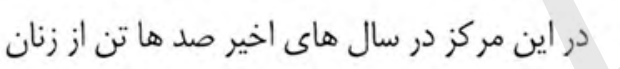

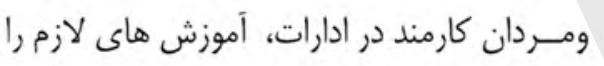
فراكرفته اند. وى هدف اصلى ايجاد اين مركزرا ارتقاى ظرفيت كارى كارمندان دولت بيان نمود.

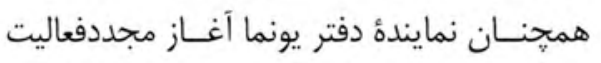

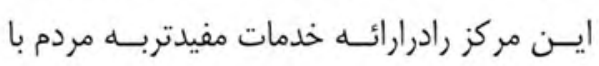

اهيمت دانست.

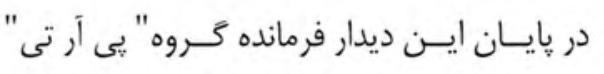

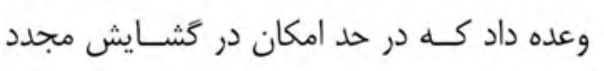

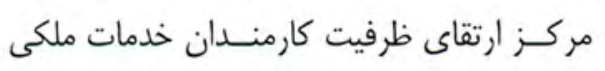
،مقامات هرات را همكارى نمايد. تخزارشحَر زون غرب: عبدالستار الكوزى نمايد

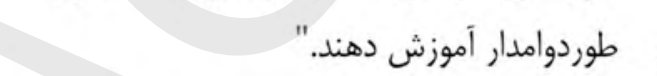

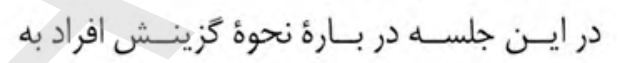

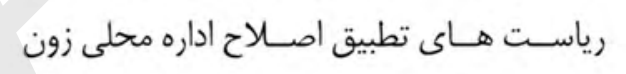

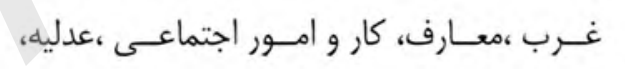

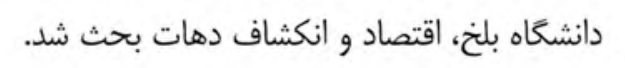

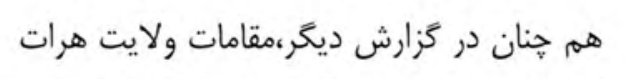

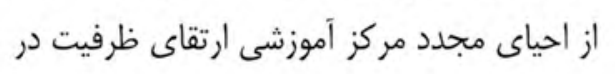
اين ولايت خبر دادند. "اصيـل الدين جامى" معاون و سريرسـت مقام آلام

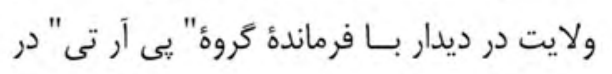
حالى كه مسؤولان دفتر ساحوى تطبيق اصلاح

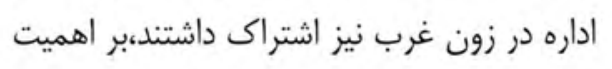
احياى مجدد اين مركز تأكيدنمودند. آقاى جامى بابيان علـل توقف فعاليت هاى اين إكلين

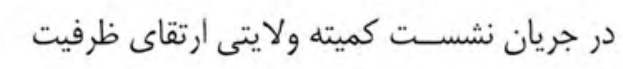

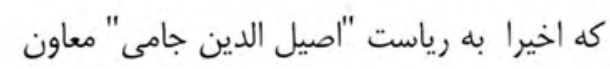

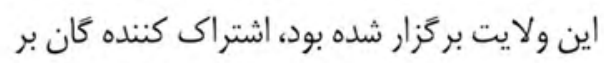
تدوين برنامة جامع ارتقاى ظرفيت تأكيد نمودند.

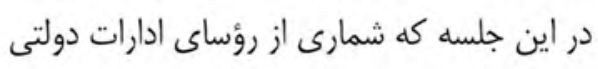

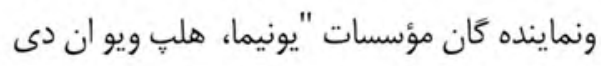

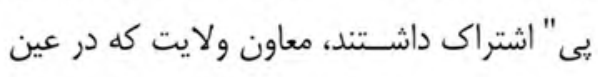
حال رياسـت كميتهٔ ارتقاى ظرفيت را نيز عهده

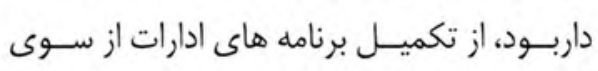
مديريت ارتقاى ظرفيت مقام ولايت خبرداد.

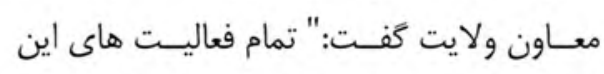

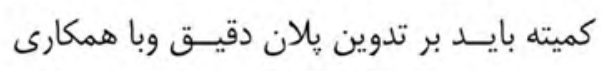

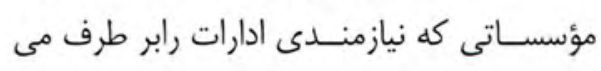

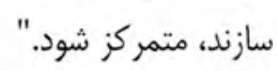
در هميـن حال نمايندة "يــو ان دى بى " كفت: 
ارزيابـى بيـشُ از مهار همزار هأهور حُتهاتْ مالكسى در

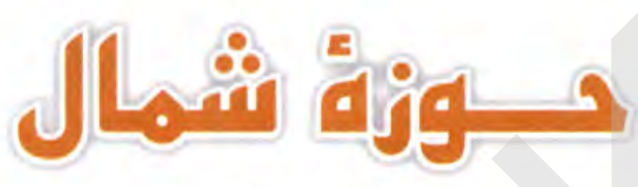

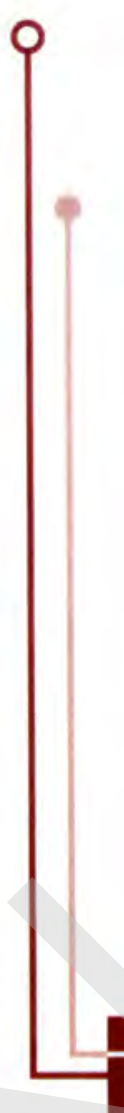

كَفتكويى با "احمد جاويد ياور" أمر خدمات ملكى حوزه شمال

فرمان رئيس جمهور و بلآخره با مسجل شدن در قانون اساسى افغانستان در سال rیrا هجــى - خورشــيدى به منظور ايجاد يك ادارٔ سـالم ، ياسخكُو و مردم

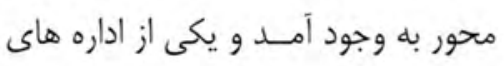

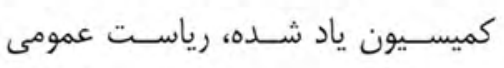

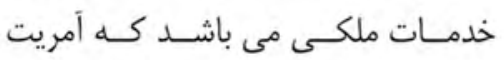
خدمات ملكسى در حوزه هاى هفت كانه

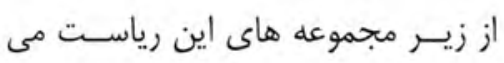
باشد وبه طور فشرده فعاليت هاى آتى از

$$
\text { وظايف اساسى آن مى باشد: }
$$

• نظارت ازصورت تحقق پاليسـى هاى خدمات

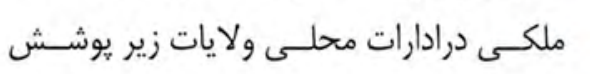

$$
\text { دفتر ساحوى شمال. }
$$

• تشـــيص عامل پاييـن بودن سـطح كارايى مأموران خدمات ملكـى ادارات دولتى ولايات

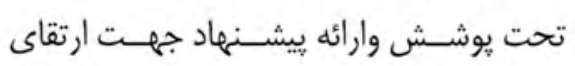

كى آنها براى ييشرفت ، توسعه و نوآورى درآمده و تطبيق مى گردد. رياست خدمــات ملكى كميسـيون مسـتقل كرد اصلاحات ادارى در تمـام حوزه هاى هفت كانه كشور يك نفر كارمند را تحت عنوان "آمر خدمات ملكى "مؤظف سـاخته است تا مسؤوليت ارزيابى

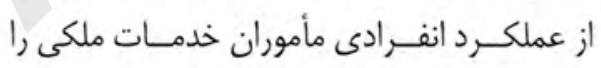
به دوش داشته باشـــ. براى آشنايى بيشتر بالين

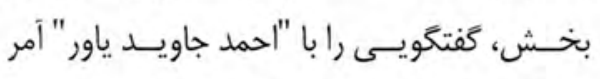
خدمات ملكى حوزه شــمال انجام داده ايم كه در زير مى خوانيد.

يوسش: آقاى "يـاور" عمده ترين فعاليت هاى اين بخش كدام ها است؟

هاسخ: همانطــورى كـهـه در جريـان هسـتيد، كميســيون مسـتقل اصلاحات ادارى و خدمـات ملكى بر مبنـاى توافقات بُن ،

\section{يادآورى:}

ارزيابى هم براى سازمان و هم براى نيروى كار،

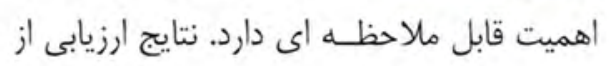

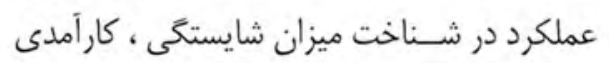
و كارايى واحدهــاى مختلف مانند: ادارى و مالى ، كزينش ، اسـتخدام ، برنامه ريزى نيروى كار ،

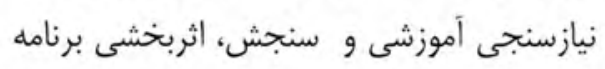
هاى آموزشى بركزار شده ، تعيين سيستم برداخت

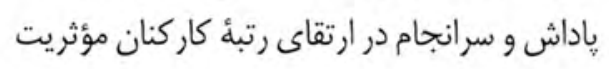

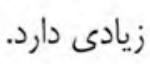
ارزيابى از عملكرد توســ رياست خدمات ملكى داردي

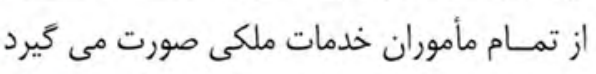

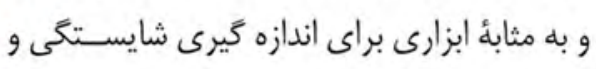

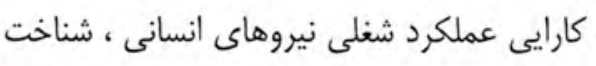
توانمندى كاركنان ، ميزان تحقق عملكرد آنها به برنامهٔ. مورد نظر در عرضه و ارائه خدمات و آماده 
تحت يوشَش ،با روند ارزيابى از اجرالً

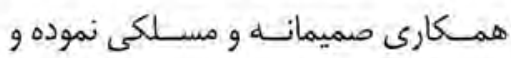
مشـكل خاصى دتوجه كارها نيسـت ( به اسـثناى ديتابيس و مديريت سوانح مقام ولايـت بلخ كه يكى سلسـله كاسـتى ها

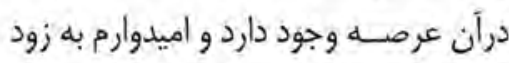
ترين فرضت حل كردد).

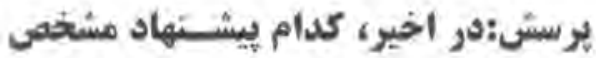

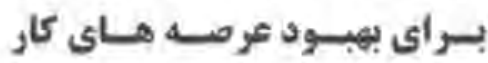
10 هاسخج:ترتيب طرزالعمل ارزيابى از اجراآت،ترتيب

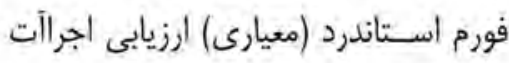

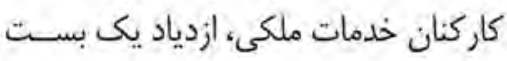
در آمريت خدمات ملكى براى تسريع امور. از شمار يبيشنهادهايمم مى باشد.

سيد عنايت الله كلانتر
درصــورت مؤفقيـت، به يكى قــدم بالاتر

$$
\text { ارتقاء مى نمايد". }
$$

بي سش: به نظور شـما ارزيابى از اجرآت

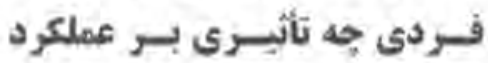
هأموران فارئ ياسخ: خــوب، ارزيابى از الجرآت فــردى اثرات

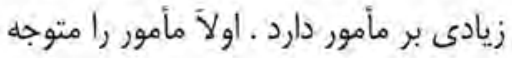

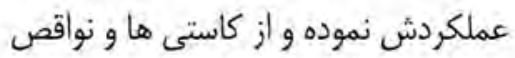

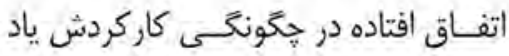

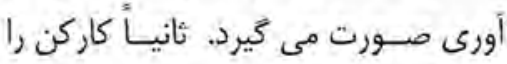

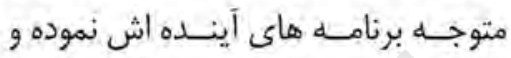

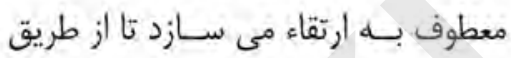
عملكرد مؤثر و مثبت، به قدم هاى بعدى

نايل گردد.

همينطور ارزيابى از اجرآت فردى ، مأمور خدمات

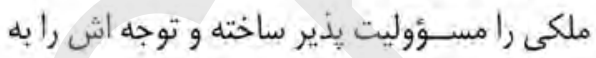

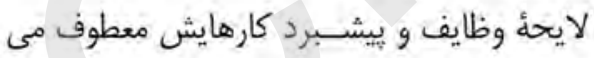

كرداند.

\section{بو نسش:تا حسال جـــ تعـداد أز مأموران} خدمات ملكى راتر حوزة شــمال

\section{ارزيابى نموده ايدي؟}

باسفخ: از آغاز تقرر بئده در اين سـمت ( ازئ سال

ع人זו الى ربع اول سال •وזו) به تعداد

Fأff

در ينج ولايت زير يوشـش دفتر ساحوى

شــمال تحت ارزيابى اجرآت قراركرفته

است.

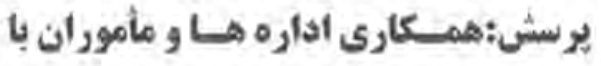
روند الززيابى خكوثه است؟ باسِخ: مأمــوران و مســؤولان در تمــام ولايات
ظرفيـت كارى آنهابه رهبــرى اداره مربوط و كميسيون:

• رهبرى وتنظيـمه امورء راه انـدازى كورس ها

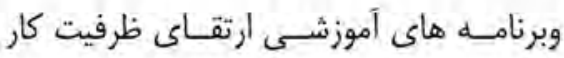
درولايات تحت يوشـش كه ازطرف انستيتوت خدمات ملكى وسايرمراجع بركزار مى شود؛ • نظارت ازضورت تطبيق يكسان قوانين ومقر رات مربوط بـه خدمات ملكى درادارات ولايات زير يوشُش ( يعنى يروسه هاى معأشات، امتيازات،

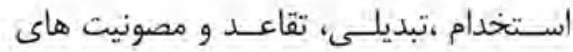
محيط كارى)؛ • تشـخيص وتثبيت مأموران ملكى واجد شرايط

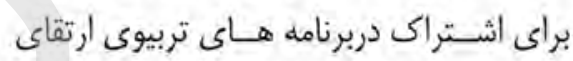
ظرفيت به همكارى ادارات مربوط.

بوتش:مأموران نحث كمأم شوائل مورد

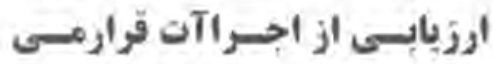
كيرندي كئ. هأسخح: مأمـوران خدمـات ملكى مطابـق ماده

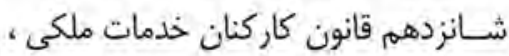
به اساس لايحه وظايف،يلان منظورشده وكــزارش اجراأت،تحست أرزيابى قرارمى

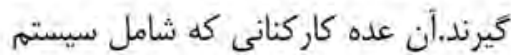

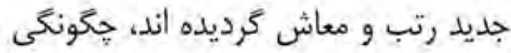
نتيجـهـ كيرى از ارزيابسى أنها طبق حكم جزr فقره ب مادئ شانزدهم قانون كاركنان خلمات ملكى صورت مى كيرد كه جنين مشعراست:" (كاركن خدمات ملكى بعداز سـيرى نمودن شش ماه در بست موجود،

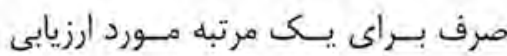

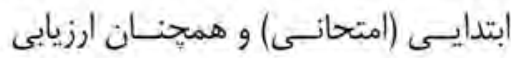
اجراآت سـالانه در اخير هر سـال اعتبار از تاريــخ اسـتخدام تحقـق مسى هذيردو 


\section{عدم همكارى شركاى}

\section{كميسيون در شهاك له}

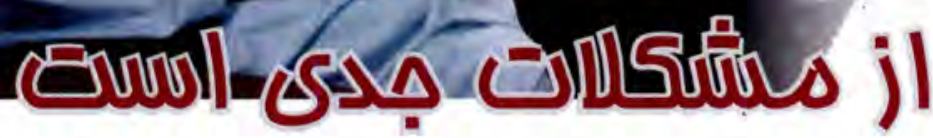

اداره ينداشـته و افـزود كه تفتيـش بدون توجه

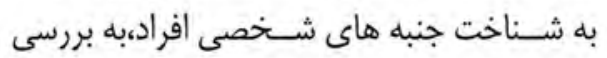
فعاليت هاى آنان مى يردازد. رئيس تفتيـش داخلى، با برشــمارى كاركرد هر يك از بخش هاى دفتر ساحوى شمال، نواقصى بـ برى برى راكــه در فعاليت بخش هــاى مخلتف اين حوزه وجود داشت، يادآور شد. هيأت تفتيش، بخش مالى و ادارى دفتر ساحوى دادى شمال كميسيون را مهم دانسته و از كاركردهاى اين بخش در طول سال 19 انتقاد نمودند. هيأت متذكـــه، از رئيس دفتر سـاحوى تطبيق اصلاح ادارٔ محلى شمال خواسـت تا در رفع مشكلات اين بخش اقدام نمايد. آقاى دستخير با تأئيد سخنان رئيس دفتر ساحوى بلري

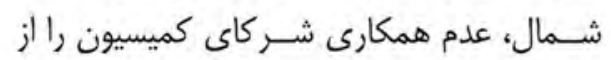
مشـكاتلات جدى دانسته،تأكيد كرد كه مشكلات شـركاء را بــا هيأت رهبرى كميسـيون در در ميان خواهد كذاشت. در يايان نشســ، رئيس دفتر سـاحوى شـمال نارسـايى هاى بخش ادارى و مالـى را يذيرفته و

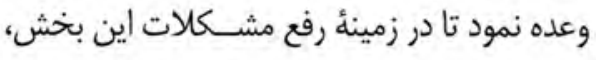
اقدامات جدى را روى دسـت كيرد.در اين نشست افزون بــر رئيس تفتيش داخلى كميســيون،آقاى رونى "غفران ذكى" كارشناس تفتيش داخلى و شمارى نئي از كاركنان دفتر ساحوى شمال نيز حضور داشتند.
نمـوده، افزود:" اميدوار هســتم مســؤولان تمام

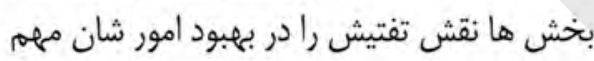

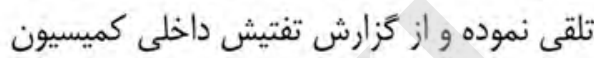
در رفع نواقص خويش استفاده نمايند".

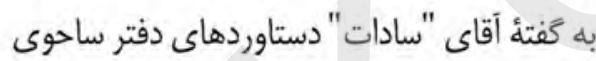
شمال كميسـيون در جريان سال كذشته در اين حــوزه، قابل ملاحظه بوده و مورد قناعت رهبرى سي

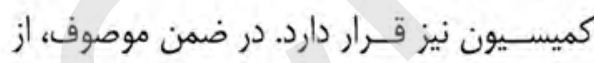
شمارى نارسايى هايى ياد آورى نمود كه فعاليت كارمندان دفتر سـاحوى شمال را مورد انتقاد قرار مى دهد. آقـاى "ســـادات" عـلاوه كرد:"عـدم همكارى تعدادى از ادارات دولتى سبب عقب مانى اموركار كميسـيون در سطح حوزه شــمال مى كردد ؛بناً ما منحيث تسـهيل كنندة شــرايط براى عرضئ خدمت رسـانى ،خواهـان توجه مقامـات دراين زمينه هستيه". "احمــــــــان دســتخير " رئيس تفتيـش د داخلى كميسـيون مســقل اصلاحسـات ادارى بــا بيان

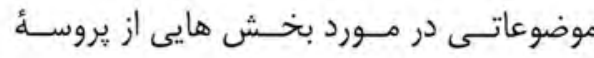
تفتيـش در حوزة شــمال،كاركرد ها و دســاورد

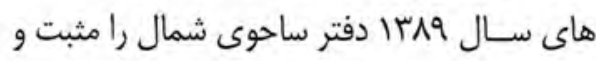
ارزنده دانسته، از مسؤولان آن به خاطر تلاش و زحمات شان در راستاى تطبيق اهداف راهبردى به

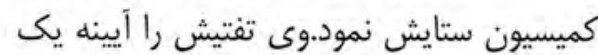

اخيراً برنامهٔ تطبيق تفتيش داخلى كميسـيون در دفتر ساحوى تطبيق اصلاح ادارٔ محلى شمال به به بهي خايان رسيد و در نشستى كه كاركنان اين دفتر با رئيس تفيتش داخلى كميسيون مستقل اصلاحات ادارى و خدمات ملكى داشتند،از فعاليت هاى سال يار اعضاى اين نهاد قدردانى صورت گرفت.

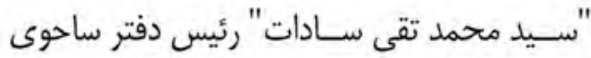
تطبيـق اصلاح اداره محلى شــمال، يايان برنامه تفتيش دفتر ساحوى شمال كميسيون را مؤفقيتى در زمينهُ تطبيق برنامهٔ سـالانهُ رياسـت تفتيش داخلى كميسيون دانست. وى علاوه كرد، برنامئ سـالانئ تفتيش داخلـى كميسـيون در حقيقت دانس

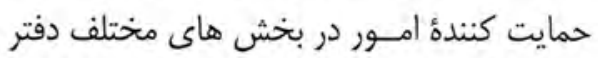
مى باشد كه با برملا ساختن نواقص و كمبودات، مسبب رفع أنها مى كردد. رئيسـ دفتر سـاحوى شـمال كميسـيون تنها سازمانهايى را مؤفق دانست كه به بهترين وجه از منابع خود استفاده نموده و بيشترين بهرهورى سلى را مى داشـته باشند. وى كفت:"من تعهد خود را براى آوردن تغيير، رفع نواقص و كاســى ها ابراز مى دارم و از آخرين امكانات دست داشته خويش لون

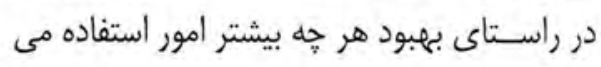

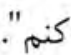
"سـادات"، عملكــرد بخش هـــــ مختلف دفتر

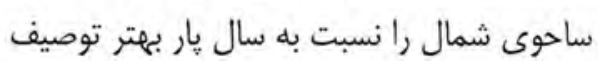




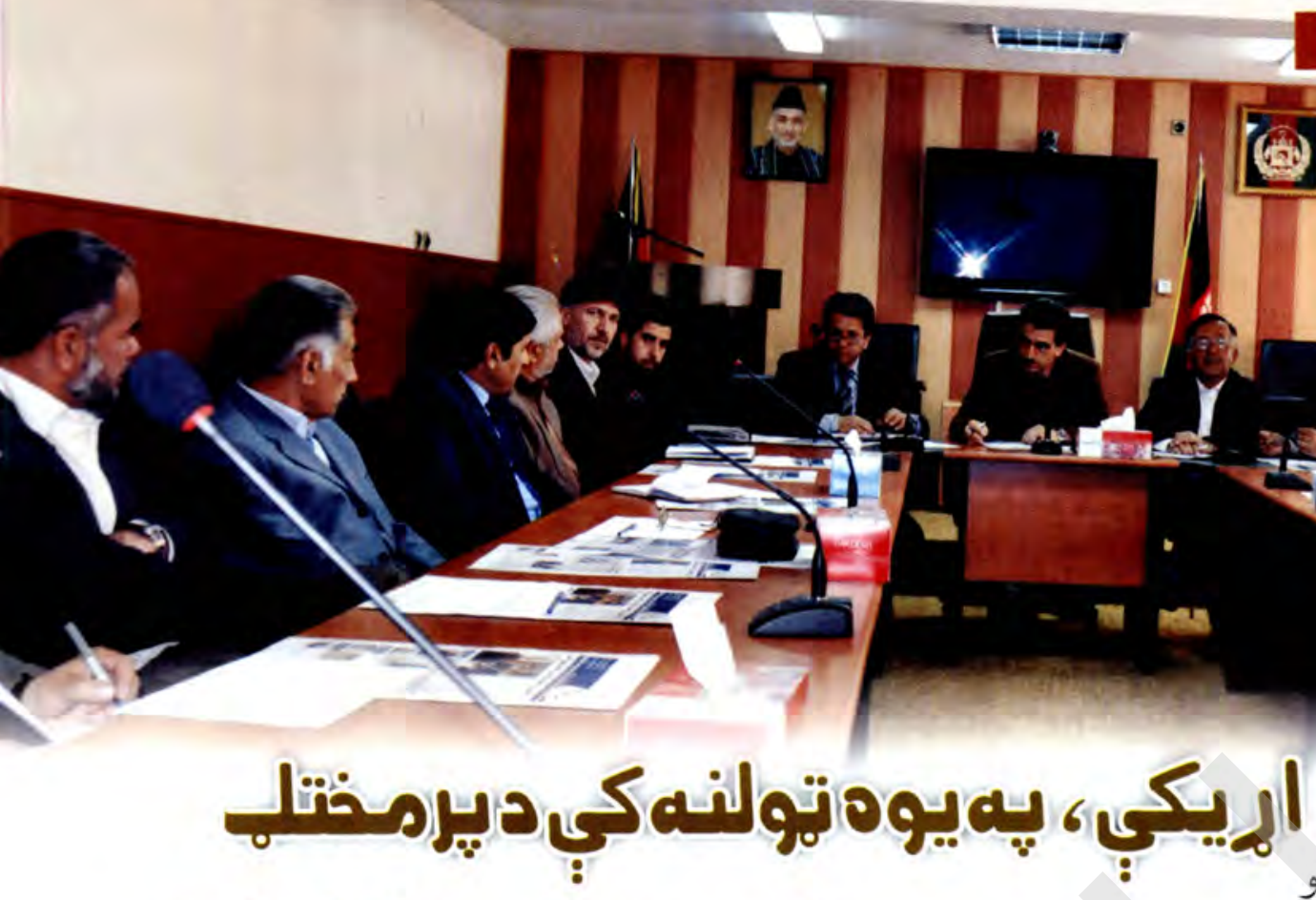

يه دي وروسـتيوكي د اداري اصلاحاتو

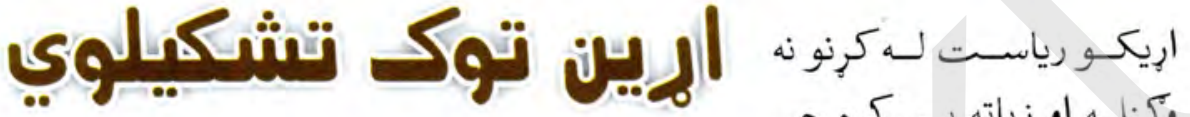

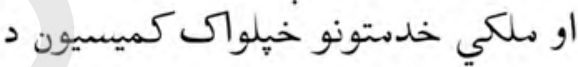

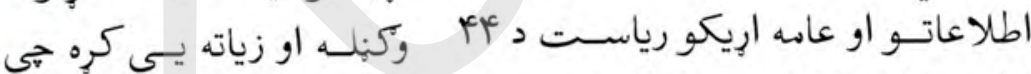
يـهـ نشــاتي ادارو كـي دي

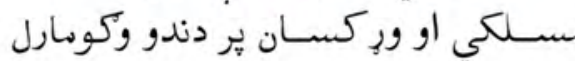

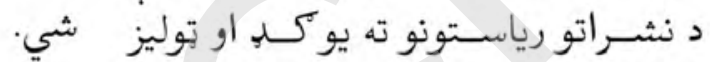

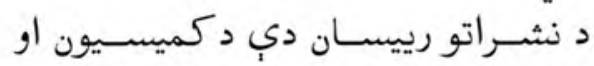

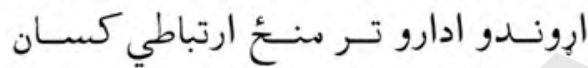
اوسي. د اطلإعاتو او عامه اريكو رياسـت لياره

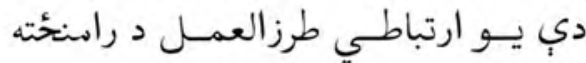

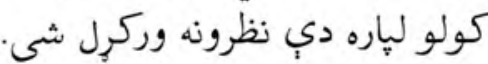

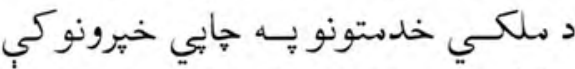

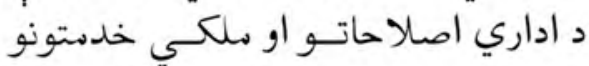
دكرنــو د انعكاس وركولو هاره د ديو كالم جورئل ارين دي.

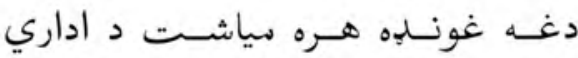

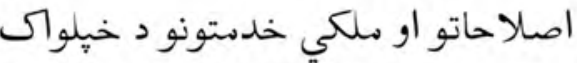

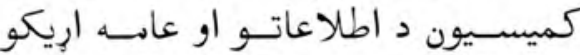

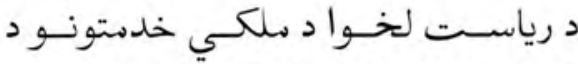
نشراتي ادارو تر منحُ د همغرِى ڤِ موخه جوري.ي.

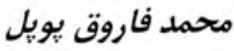

دغي اداري د نورو نشئسراتي

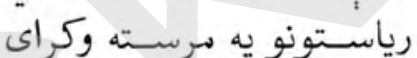
(اطلاعات او عاسه اريكي) نوم وباكي. محمـد يونس صديقسي دكار، تولنيزو

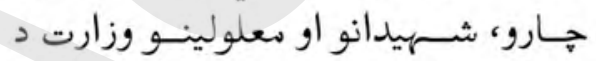

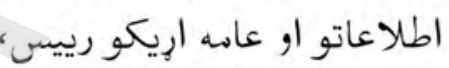

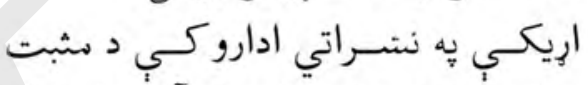

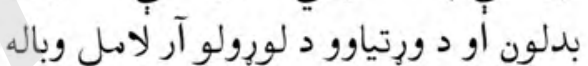

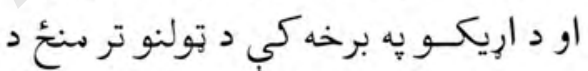
لا جيرو غونندو جويرولو غوبنته وكره.

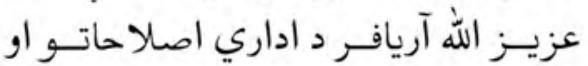

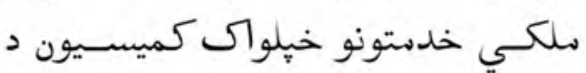

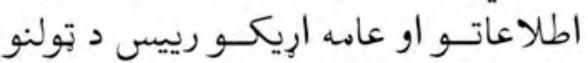

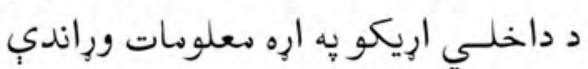

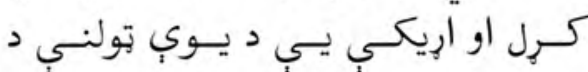
يردختك ارين توك وبللي.

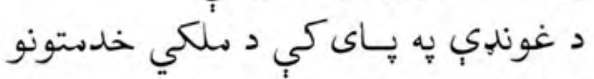

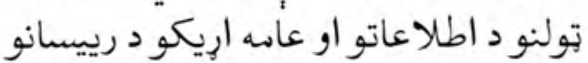
لخوا داسي يريكره وشوه خي:

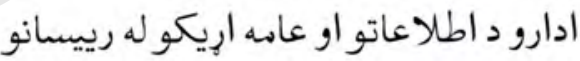
سـره د ملكي خدمتونو دكنفرانسونو خه تالاركي مياشتني غونده وكره.

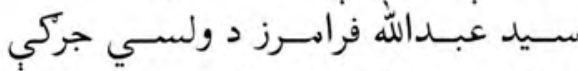

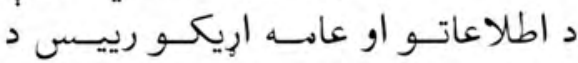

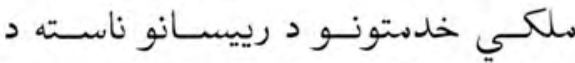

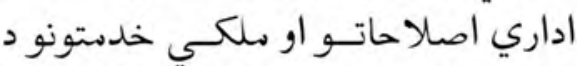

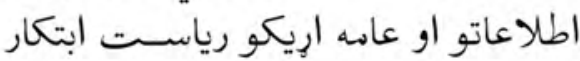
او لاسته راورنه وبلله او زياته بي كرّه جي إسي

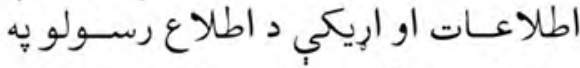
برخه كي حُانكرِى اهميت لري.

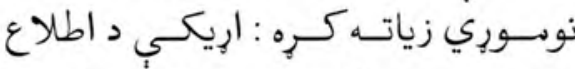
رسولو يه برخه كي بنستيز توك شميرل

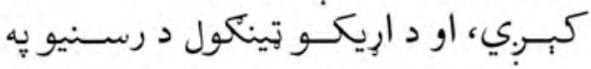
برخـهـي د هر راز كرنو اساسـي موخه .02 محمد هاشـم صافي د لوبي خارنوالى د دارد اطلاعاتو او عامــه اريكو رييس د اريكو

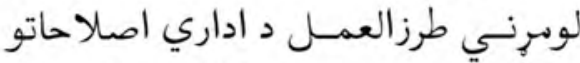

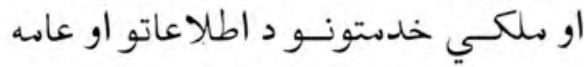


ظرفيت كاركنان خدمات ملكى را مسـاعد سازد از

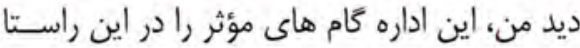

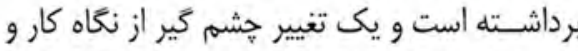
عرضه خدمات بهتر در كشور ايجاد شده است.

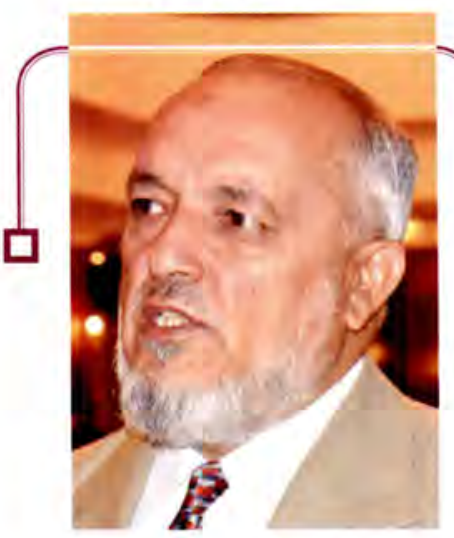

معيـن مالـى و ادارى وزارت عدليـه، سيسـتم اصلاحات ادارى رادر كشور

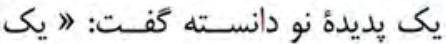
سلسله مشكلات در سيستم اصلاحات ادارى وجــود دارد؛ ولـى بــا بركزارى اصلى

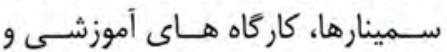

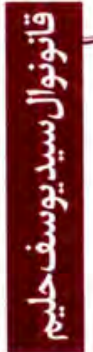

تبادل نظــر متخصصان مى توان در اين يروسـهـ

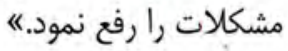
حليم افزود: " در كثــور ماليزيــا به منظور عرضه

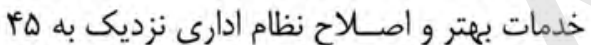

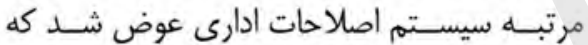
اكنــون عرضه خدمـات بهتر و كاركنـان خدمات ملكى در آن كشور با تعهد كار مى كنتد."

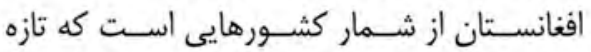
اصلاحسـات را در نظام ادارى مورد تطبيق قرار داده و به نظر من تطبيق اصلاحات نيازمند زمان است تا به يخته گیى برسد و روزى فرا رسد تا اداره هاى نطاى ملكـى مطابق نيازمنديها عيـار كرديده و مردم از عرضه بهتر خدمات از آدرس دولت مطمين شوند.

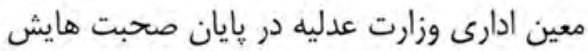

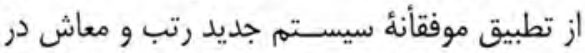

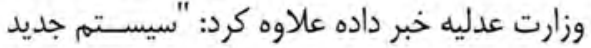
رتب و معاش از دو سال به اين سو در وزارت عدليه تا به سطح ولسوالى ها تطبيق گرديده است." "محمد فاروق يويل"
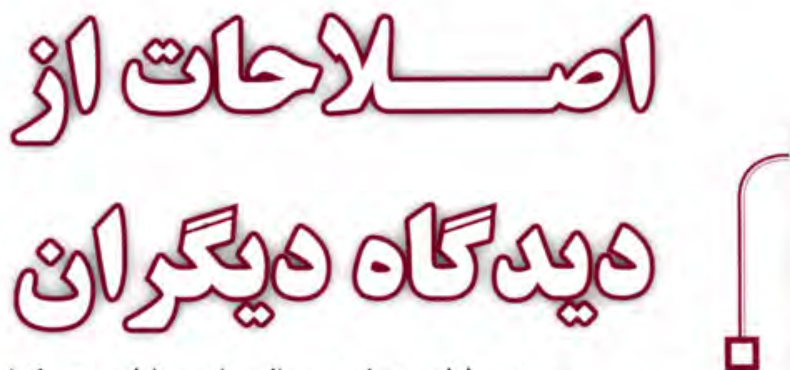

\section{(3)}

بـوده و اداره هـــا در حــال حاضر داراى تشـكيل

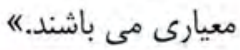

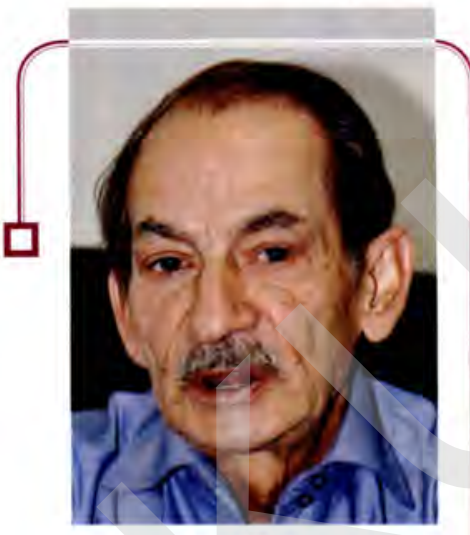

مشاور ارشد وزارت اطلاعات و فرهنى

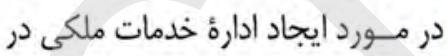
كشور كفت: "اساساً اداره در افغانستان

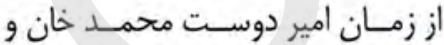
امير شــيرعلى خان بنيان كذارى شده و سيسـتم ادارى در كشور به فعاليت

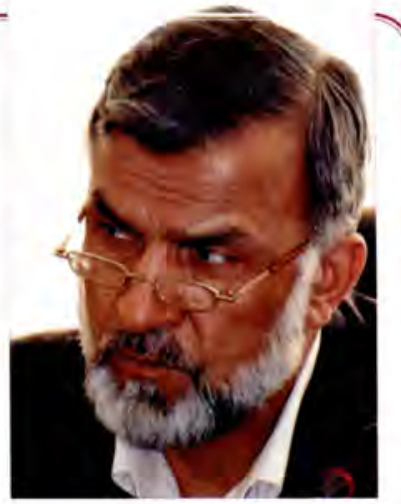

معين يلانكذارى وزارت امور سرحدات،

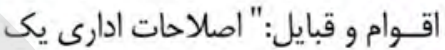
يروســـ خوب در نظام ادارى كشــور

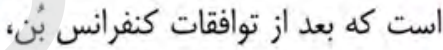

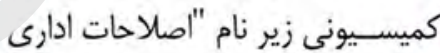

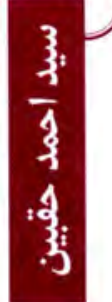

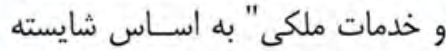
سالارى ايجاد شد و اين كميسيون از آغاز كارش،

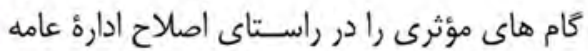
كشور برداشته است".

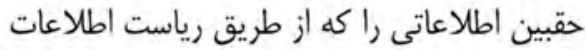

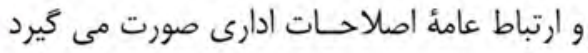

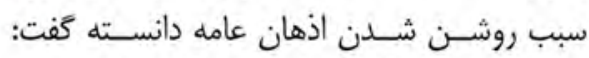

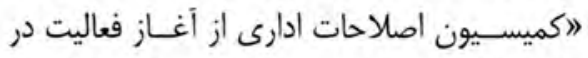
در آن زمان آهسـته آهسـتهـ تكنالورى يك مقدار

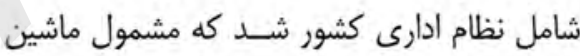
هاى تايب، كارتن ها، تيلفون، فاكس و و ... بود؛ اما

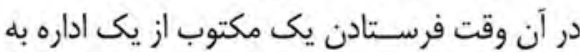

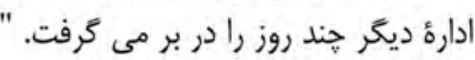
نورانى عصر حاضــر را داراى خصوصيات جداثانه دانسته و بيان داشت: "عصر حاضر، عصر كمييوتر است و كار در اين زمان به سرعت انجام مى شود

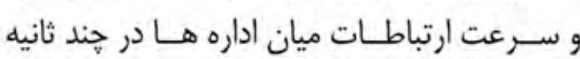

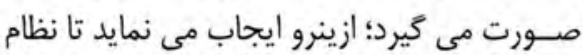

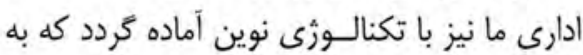
همين اسـاس اداره يى زير نام كميسيون مستقل اصلاحات ادارى و خدمات ملكى ايجاد شد تا اداره

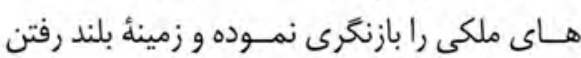

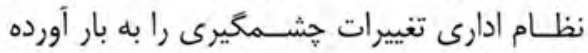

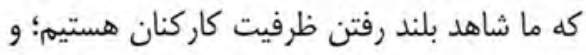

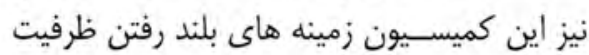
كاركنان خدمات ملكى را در داخل و خارج كشــور

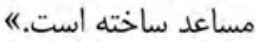
معيـن يلانغـــارى وزارت امور ســـرحدات افزود:

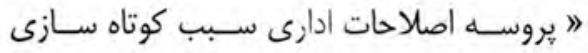

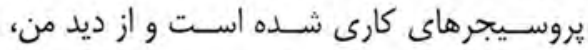

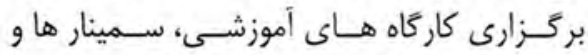

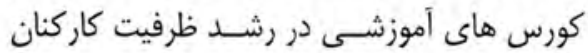

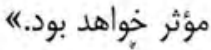
وى علاوه نمود: "روند اصلاحات ادارى سبب تغيير

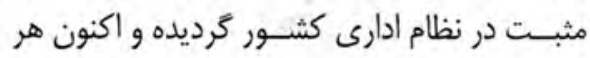
يُست كاركنان خدمات ملكى داراى لايحهُ وظايف 

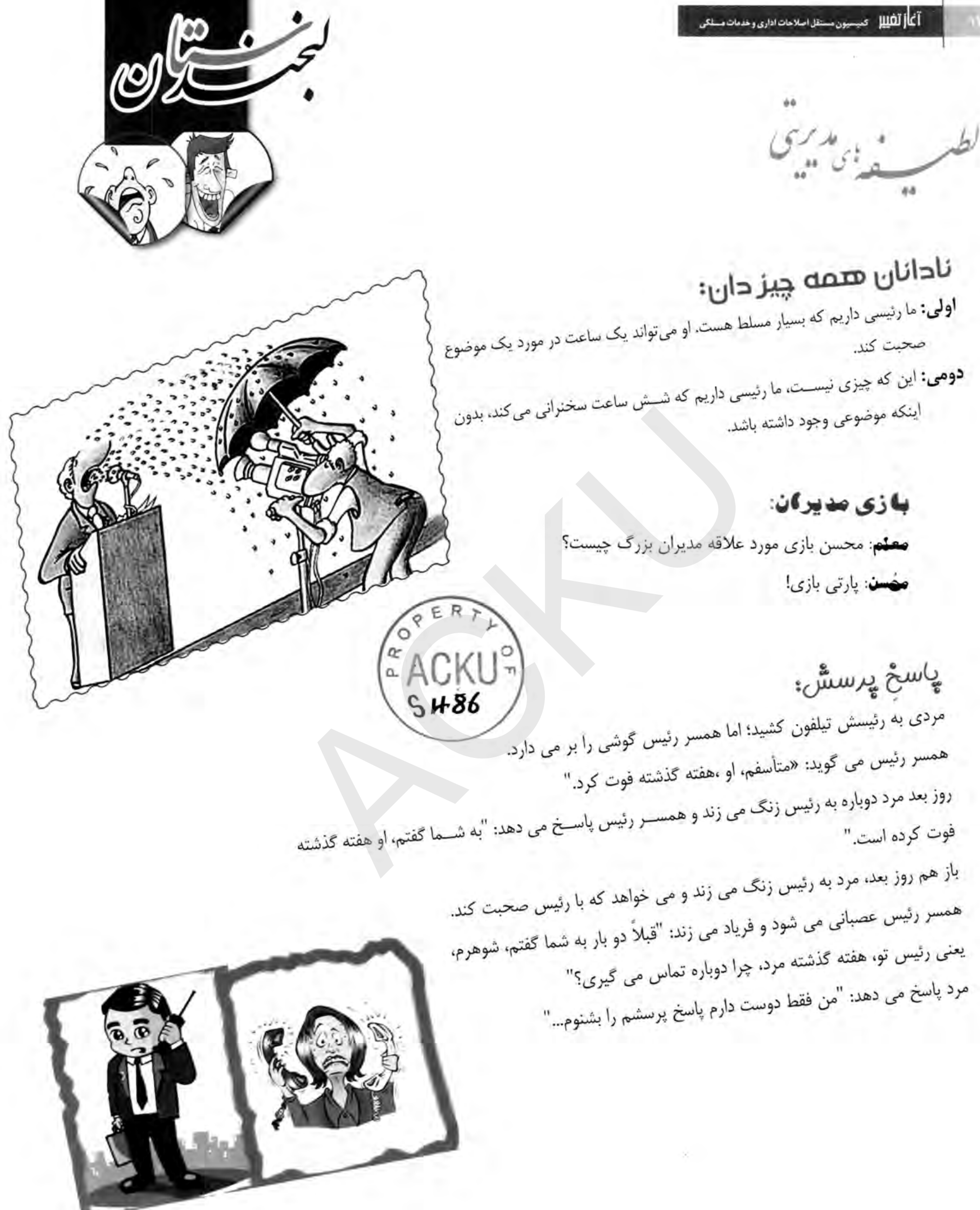


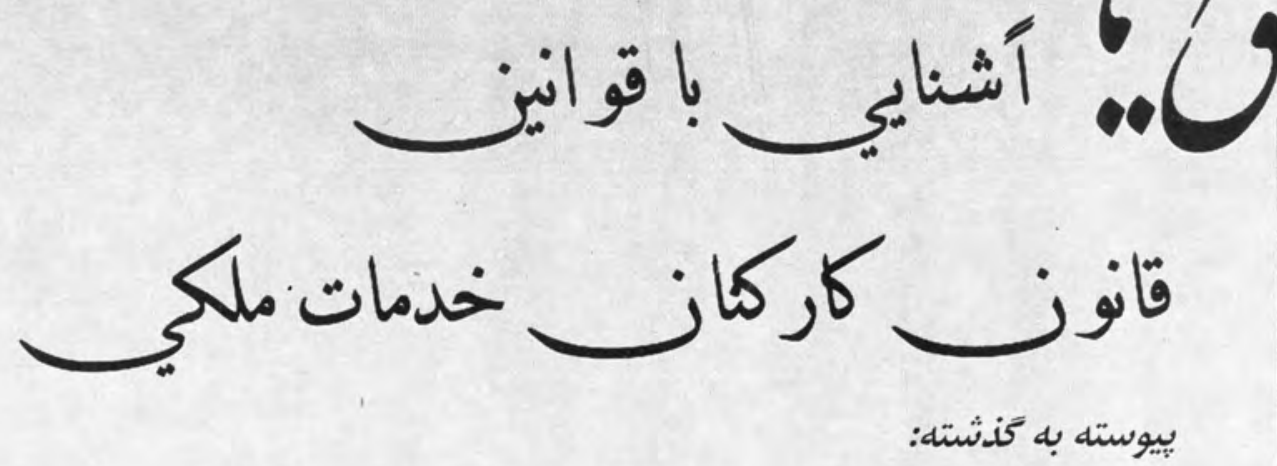

مصونيت

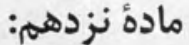

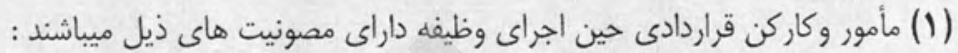

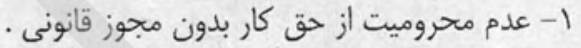

r- حفظ كرامت انسانى ، تأمين مصئونيت أز آزارو اذيت بـانيت جسمانى، اخلاقى و وروانى.

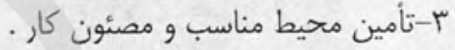

(T) شرايط و طرز استفاده از مصونيت ها ماسى مندرج فقره (1) اين ماده توسط سند تقنينى مربوط تنظيم ميكردد.

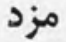

ماده بيستم: مزد:

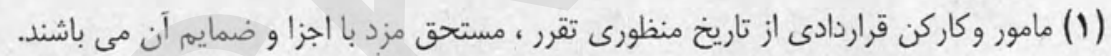

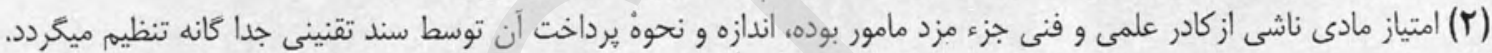

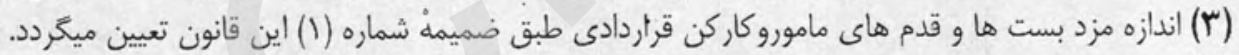

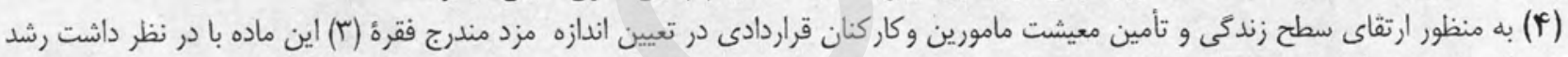

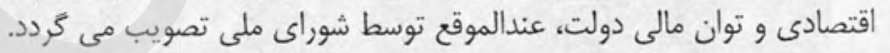

اضافه كارى

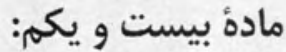

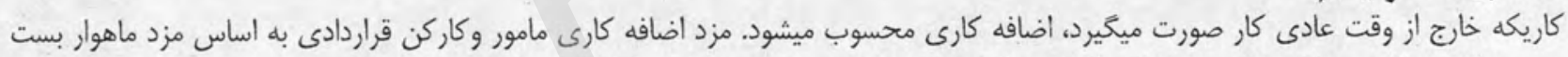

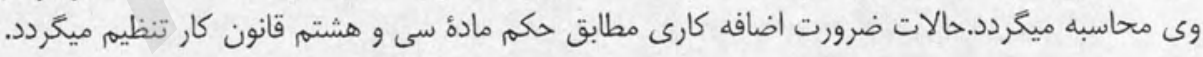

ماده بيستى دورتى مامور وكاركن قراردادى مستحق رخصتى هاى با مزد طبق أحكام مندرج مواد (وسالى هـ ) قانون كارميباشند.

$$
\text { ماده باز بست و ارتقاى قدم }
$$

(1) مامور ميتواند، طبق احكام اين قانون به اساس رقابت، بست بالاتر را الحراز نمايد.

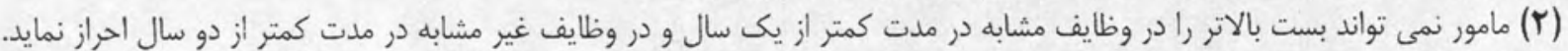

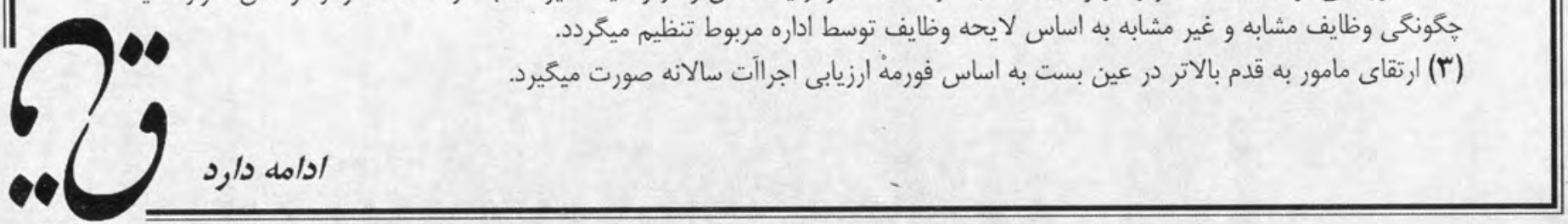



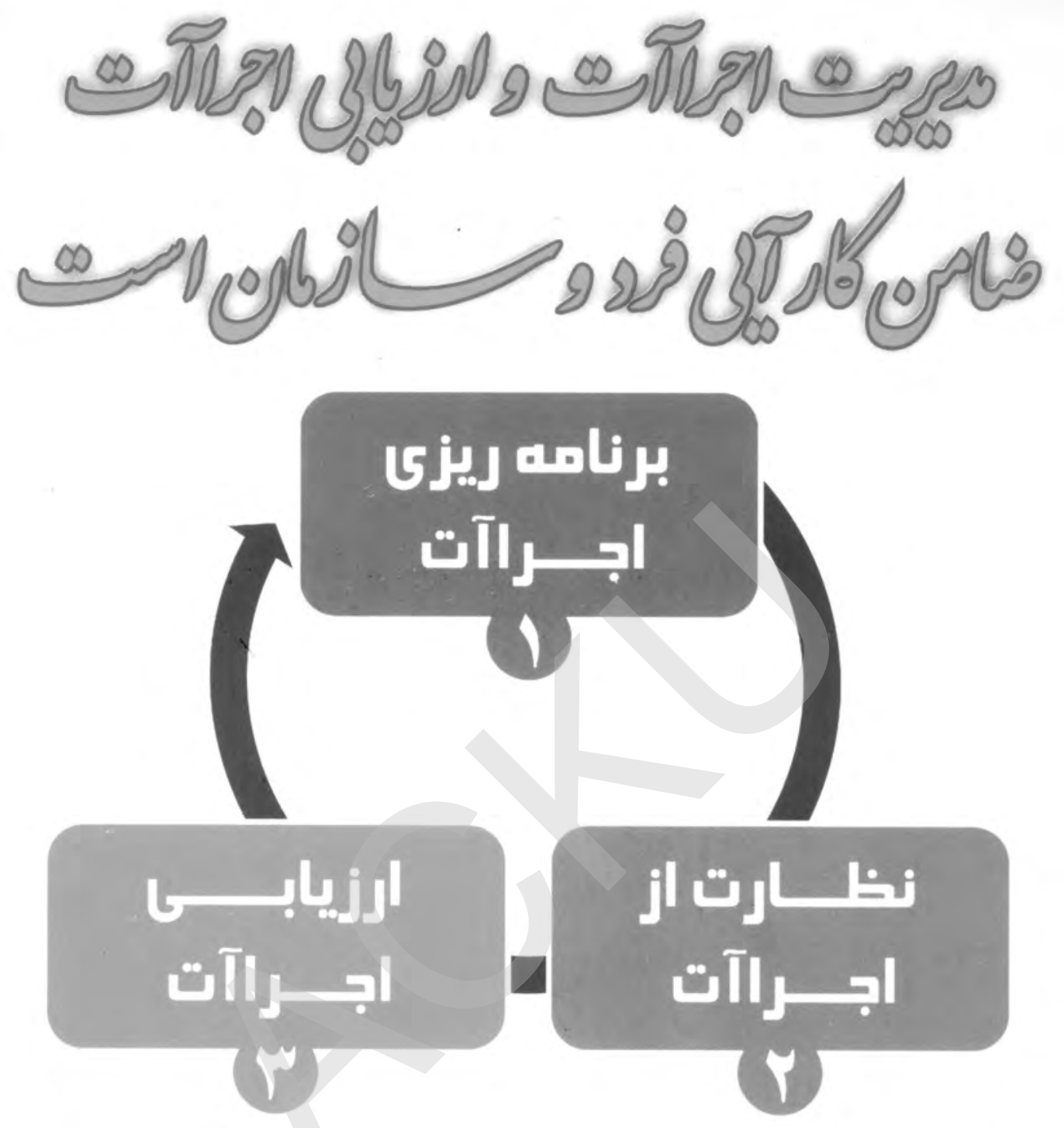

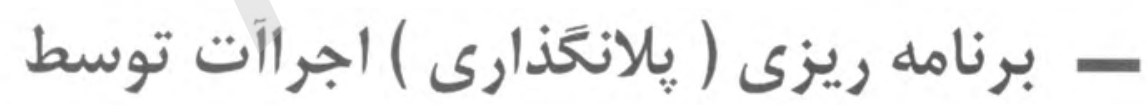

آمر بخش و همكاران در آغاز سال.

- - نظـارت از اجراآت و رهنمايى كاركن به

صورت متداوم توسط آمر بخش.

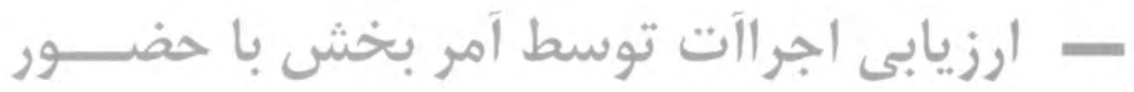

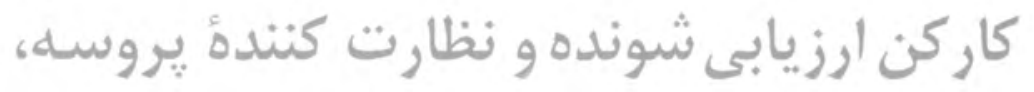

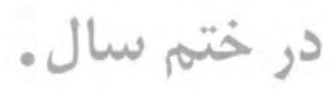

